\title{
DINÂMICA DA REBROTAÇÃO DE PASTOS DE CAPIM-MOMBAÇA SUBMETIDOS A REGIMES DE DESFOLHAÇÃO INTERMITENTE
}

\section{ROBERTA APARECIDA CARNEVALLI}

\author{
Tese apresentada àEscola Superior de Agricultura "Luiz \\ de Queiroz", Universidade de São Paulo, para obtenção \\ do título de Doutor em Agronomia, Área de \\ Concentração: Ciência Animal e Pastagens.
}

P I R A C I C A B A

Estado de São Paulo - Brasil

Outubro - 2003 


\title{
DINÂMICA DA REBROTAÇÃO DE PASTOS DE CAPIM-MOMBAÇA
}

\section{SUBMETIDOS A REGIMES DE DESFOLHAÇÃO INTERMITENTE}

\section{ROBERTA APARECIDA CARNEVALLI}

Engenheiro Agrônomo

Orientador: Prof. Dr. SILA CARNEIRO DA SILVA

\begin{abstract}
Tese apresentada àEscola Superior de Agricultura "Luiz de Queiroz", Universidade de São Paulo, para obtenção do título de Doutor em Agronomia, Área de Concentração: Ciência Animal e Pastagens.
\end{abstract}

P I R A C I C A B A

Estado de São Paulo - Brasil

Outubro - 2003 
Dados Internacionais de Catalogação na Publicação (CIP) DIVISÃO DE BIBLIOTECA E DOCUMENTAÇÃO - ESALQ/USP

Camevalli, Roberta Aparecida

Dinâmica da rebrotação de pastos de capim-mombaça submetidos a regimes de desfolhação intermitente / Roberta Aparecida Camevalli. - Piracic aba, 2003.

136 p. : il.

Tese (doutorado) - Escola Superior de Agric ultura Luiz de Queiroz, 2003. Bibliografia.

1. Capim mombaça 2. Desfolha 3. Pastejo (manejo) 4. Rebrota I. Titub

CDD 633.2 
"Tenha fortaleza de ânimo, para resistir a todos os embates e tempestades do caminho. Não se iluda: mesmo a estrada do bem está cheia de tropeços e dificuldades... Continue, porém! Não dê ouvidos às pedras colocadas pela inveja, pelo ciúme, pela intriga... Marche de cabeça erguida, confiantemente, e vencerá todos os obstáculos da caminhada. E, se for ferido, lembre-se de que as cicatrizes serão luzes que marcarão a sua vitória"

Por Carlos Torres Pastorino 


\section{DEDICO ESSA OBRA}

Aos meus pais Élide e Valter, pela paciência, ajuda e carinho, ao meu marido Reginaldo, pelo companheirismo, apoio, incentivo, carinho, paciência e amor e, especialmente, ao meu filho Renato cuja presença iluminou minha vida.

\section{OFEREÇO:}

Ao meu Orientador Sila Carneiro da Silva como um presente de sua primeira aluna de Doutorado e como forma de agradecimento pelos 9 anos de convivência. 


\section{AGRADECIMENTOS}

À Escola Superior de Agricultura 'Luiz de Queiroz" pela oportunidade de desenvolvimento do curso de Doutoramento

Ao Departamento de Produção Animal pelo apoio logístico

Ao Professor Sila Carneiro da Silva pela orientação, ensinamentos, compreensão e paciência e oportunidades.

Aos Professores da Esalq que colaboraram na minha formação

À Fundação de Amparo à Pesquisa no Estado de São Paulo pelo financiamento do projeto

À Universidade Federal de São Carlos pela receptividade

Ao Professor Jozivaldo Prudêncio de Morais pela concessão da área experimental e dos animais

Aos membros da Banca Examinadora pela atenção e dedicação no exame da Tese

À Dora Duarte de Carvalho, Patrícia Sarmento e Roberta Valente pela amizade 
Às alunas de Mestrado, Adriana Amaral de Oliveira Bueno e Marina Castro Uebele, pelo importante auxílio durante o período experimental

Aos alunos de Graduação, Fernando de Oliveira Bueno, Glaciliana Nunes da Silva e Paulo pela ajuda durante a coleta dos dados no campo

Aos alunos de graduação da ESALQ (Gepf) e da UFSCar (Getap) pelo auxílio nos momentos mais críticos

Ao funcionário "Índio" da Ufscar pela eterna presença durante o período experimental

Ao Reginaldo Jacovetti pelo auxílio, mas principalmente pelas palavras de incentivo nos momentos mais difíceis

Aos meus pais pela compreensão e ajuda

Ao meu filho por me dar coragem para prosseguir

À Deus pela sabedoria, visão e força 


\section{SUMÁRIO}

\begin{tabular}{|c|c|}
\hline & Página \\
\hline UMO.. & ix \\
\hline SUMMARY. & $\mathrm{xi}$ \\
\hline 1 INTRODUÇÃO... & 1 \\
\hline 2 REVISÃO DE LITERATURA . & 2 \\
\hline 2.1 O processo de rebrotação em plantas forrageiras e a produção de forragem......... & 2 \\
\hline $2.2 \mathrm{O}$ capim-Mombaça................... & 7 \\
\hline 3 MATERIAL E MÉTODOS... & 10 \\
\hline 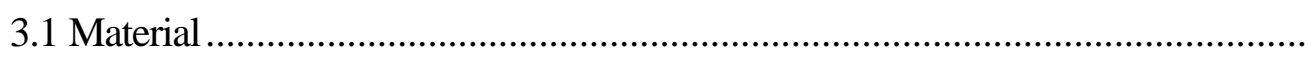 & 10 \\
\hline 3.1.1 Espécie vegetal e local do experimento ............ & 10 \\
\hline 3.1.2 Dados climáticos ..... & 11 \\
\hline 3.1.3 Solo.. & 13 \\
\hline 3.2 Métodos . & 15 \\
\hline 3.2.1 Tratamentos e delineamento experimental . & 15 \\
\hline 3.2.2 Monitoramento das condições experimentais e adubação dos pastos.................. & 17 \\
\hline 3.2.3 Avaliações ... & 19 \\
\hline 3.2.3.1 Interceptação luminosa e características do dossel forrageiro............................. & 21 \\
\hline 3.2.3.2 Dinâmica do acúmulo de forragem........................... & 22 \\
\hline 3.2.3.3 Densidade populacional e massa de perfilhos individuais.. & 24 \\
\hline 3.2.3.4 Massa de forragem.......................... & 25 \\
\hline 3.2.3.5 Taxa de acúmulo de forragem............ & 26 \\
\hline 3.2.3.6 Perdas de forragem pó pastejo ................... & 26 \\
\hline 3.2.3.7 Estimativa da forragem removida.... & 27 \\
\hline 3.2.3.8 Estimativa da forragem aproveitada (efi & 27 \\
\hline
\end{tabular}


3.3 Processamento dos dados e análise estatística..................................................... 28

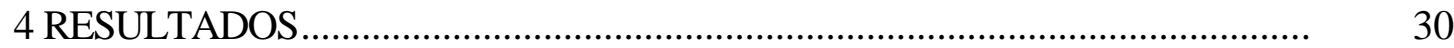

4.1 Características do dossel forrageiro ................................................................. $\quad 30$

4.1.1 Número de pastejos e intervalo entre pastejos ............................................... $\quad 30$

4.1.2 Altura do dossel..................................................................................... 33

4.1.3 Massa de forragem e composição morfológica .................................................. 36

4.1.4 Índice de área foliar.(IAF) .......................................................................... 44

4.1.5 Ângulo da folhagem................................................................................ 47

4.1.6 Interceptação luminosa ................................................................................ 51

4.1.7 Densidade populacional de perfilhos ............................................................ $\quad 57$

4.1.8 Massa dos perfilhos.................................................................................... 61

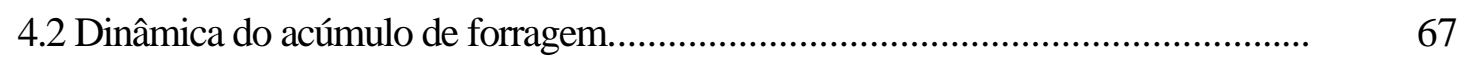

4.2.1 Lâminas foliares........................................................................................ 68

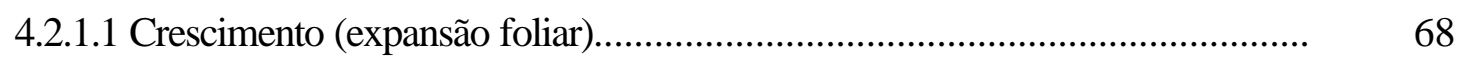

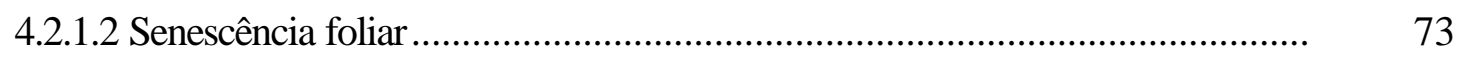

4.2.1.3 Acúmulo líquido....................................................................................... 77

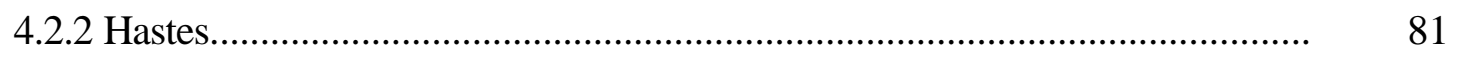

4.2.2.1 Crescimento (alongamento) ................................................................... 81

4.2.2.2 Encurtamento de bainhas e senescência de hastes......................................... 83

4.2.2.3 Acúmulo líquido...................................................................................... 87

4.2.3 Acúmulo líquido de massa seca total........................................................... 90

4.3 Produção de forragem.......................................................................................... 92

4.4 Perdas de forragem pelo pastejo................................................................... 95

5. DISCUSSÃO ......................................................................................... 102

5.1 Características do dossel forrageiro .................................................................. 102

5.2 Produção de forragem................................................................................... 112

5.3 Perdas de forragem pelo pastejo.................................................................... 122

5.4 Considerações Finais ........................................................................................ 124

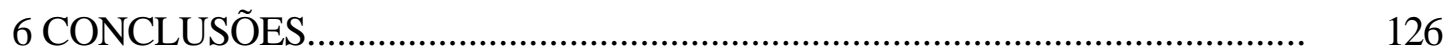

REFERÊNCIAS BIBLIOGRÁFICAS ............................................................ 127 


\title{
DINÂMICA DA REBROTAÇÃO DE PASTOS DE CAPIM-MOMBAÇA SUBMETIDOS A REGIMES DE DESFOLHAÇÃO INTERMITENTE
}

\author{
Autora: ROBERTA APARECIDA CARNEVALLI \\ Orientador: Prof. Dr. SILA CARNEIRO DA SILVA
}

\section{RESUMO}

O manejo do pastejo é fator determinante da eficiência do processo de colheita e condicionante do valor nutritivo da forragem produzida. $\mathrm{O}$ presente experimento, conduzido em área do Departamento de Biotecnologia Vegetal do Centro de Ciências Agrárias da Universidade Federal de São Carlos, Campus de Araras, São Paulo, durante o período de janeiro de 2001 a fevereiro de 2002, teve como objetivo analisar e descrever a dinâmica de acúmulo de forragem de pastos de capim-Mombaça submetidos a regimes de desfolhação intermitente. Os tratamentos corresponderam a combinações entre duas condições de pós-pastejo (altura de resíduo de 30 ou $50 \mathrm{~cm}$ ) e duas condições de pré-pastejo (interceptação luminosa pelo dossel de 95 e 100\%). O delineamento experimental utilizado foi o de blocos completos casualizados, quatro repetições e arranjo fatorial $2 \times 2$. Foram avaliadas as seguintes respostas: altura do dossel forrageiro, índice de área foliar (IAF), massa de forragem, número e peso de perfilhos individuais, alongamento e senescência de lâminas foliares e hastes, perdas por pastejo e composição morfológica da forragem. As avaliações foram realizadas imediatamente após o pastejo e a cada incremento de $20 \mathrm{~cm}$ em altura do dossel até o início de um novo pastejo. A altura do dossel forrageiro se mostrou um bom parâmetro para determinação prática d momento de entrada dos animais nos pastos, uma vez que 95 ou $100 \%$ de 
interceptação luminosa (IL) ocorreram consistentemente a 90 ou $115 \mathrm{~cm}$ de altura, respectivamente, durante todo o período experimental, independentemente do estádio de desenvolvimento das plantas (vegetativo ou reprodutivo). Os tratamentos de $95 \%$ de $\mathrm{IL}$ proporcionaram maior número de pastejos $(7,6)$ que os tratamentos de $100 \%$ de IL $(5,9)$ $(\mathrm{P} \leq 0,10)$ nos 411 dias de experimento, resultado de períodos de descanso diferenciados (24 e 35 dias, em média, para 95 e 100\% de IL, respectivamente, durante a estação de crescimento) $(\mathrm{P} \leq 0,10)$. Essa diferença foi suficiente para causar mudanças na produção e composição morfológica da forragem, na dinâmica de acúmulo de massa seca, nos padrões de perfilhamento e nas perdas por pastejo. $\mathrm{O}$ acúmulo líquido de lâminas foliares foi $6.300 \mathrm{~kg} \mathrm{ha}^{-1}$ de MS maior quando os pastejos foram realizados com $95 \%$ de IL. A partir desse ponto, as taxas de alongamento de folhas decresceram (30 para $20 \mathrm{mg}$ perfilho $^{-1}$ dia $\left.^{-1}\right)(\mathrm{P} \leq 0,10)$ e as taxas de alongamento de hastes $(0,24$ para $0,42 \mathrm{mg}$ perfilho $^{-1}$ dia $\left.^{-1}\right)(\mathrm{P} \leq 0,10)$ e senescência $\left(9,3\right.$ para $18,2 \mathrm{mg}$ perfilho $\left.{ }^{-1} \mathrm{dia}^{-1}\right)$ aumentaram consideravelmente $(\mathrm{P} \leq 0,10)$, prejudicando a estrutura do dossel na condição de prépastejo (maior proporção de hastes e material morto) e dificultando o retorno às condições especificadas de pós-pastejo, particularmente para o resíduo de $30 \mathrm{~cm}$. O tratamento de pastejos realizados com $95 \%$ de IL e $30 \mathrm{~cm}$ de altura de resíduo resultou na maior produção (25.900 $\mathrm{kg} \mathrm{ha}^{-1}$ de MS) e eficiência de colheita de forragem (82\%). 


\title{
REGROWTH DYNAMICS OF MOMBAÇA GRASS PASTURES SUBMITTED TO INTERMITTENT DEFOLIATION REGIMES
}

\author{
Author: ROBERTA APARECIDA CARNEVALLI
}

Adviser: Prof. Dr. SILA CARNEIRO DA SILVA

\section{SUMMARY}

Grazing management is a key element determining the utilization efficiency and the nutritive value of the herbage produced. This study aimed at evaluating and describing the dynamics of herbage accumulation in Mombaça grass pastures submitted to intermittent defoliation regimes. The experiment was carried out at Universidade Federal de São Carlos, Araras, SP, from January 2001 to February 2002. Treatments corresponded to combinations between two grazing intensities (30 and $50 \mathrm{~cm}$ post-grazing height) and two grazing intervals (grazing initiated at 95 and 100\% canopy light interception - LI) and were allocated to experimental units according to a complete randomized block design, in a $2 \times 2$ factorial arrangement, with 4 replicates. The following responses were measured in all grazing cycles: sward height, sward leaf area index and herbage mass, tiller population density and tiller weight, leaf and stem elongation and senescence rates, losses due to grazing and morphological composition of the herbage. Measurements were performed immediately after grazing (post-grazing condition) and at $20 \mathrm{~cm}$ increments in sward height during regrowth until the next grazing (pre-grazing condition). Sward height proved to be a satisfactory parameter for determining the timing of grazing in field conditions, since 95 or $100 \%$ canopy light interception occurred consistently at 90 or $115 \mathrm{~cm}$, respectively, throughout the experimental period regardless of plants physiological state (vegetative or reproductive). The 95\% LI treatments resulted in bigger number of grazings (7.6) than the $100 \%$ LI treatments $(5.9)(\mathrm{P} \leq 0.10)$ during the 411 days of experiment, 
that being a consequence of the resulting different intervals between grazings (24 and 35 days for 95 and $100 \% \mathrm{LI}$, respectively, during the spring/summer period) $(\mathrm{P} \leq 0.10)$. This difference was big enough to cause changes in production and morphological composition of the herbage, dynamics of herbage accumulation, tiller demography patterns and losses due to grazing. Net accumulation of leaf dry matter was $6300 \mathrm{~kg} \mathrm{ha}^{-1}$ higher when grazings were performed with 95\% LI. From

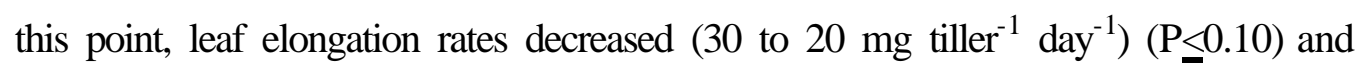
stem elongation $\left(0.24\right.$ to $0.42 \mathrm{mg}$ tiller $^{-1}$ day $\left.^{-1}\right)(\mathrm{P} \leq 0.10)$ and senescence rates $(9.3$ to $18.2 \mathrm{mg}$ tiller $\left.^{-1} \mathrm{day}^{-1}\right)$ increased considerably $(\mathrm{P} \leq 0.10)$, influencing negatively the sward structure at the pre-grazing condition (higher proportion of stem and dead material) and increasing the difficulty of accomplishing the specified postgrazing targets, particularly for the $30 \mathrm{~cm}$ residue. The defoliation treatment characterized by grazings at $95 \%$ canopy light interception $(90 \mathrm{~cm}$ sward surface height) and $30 \mathrm{~cm}$ residue resulted in the highest herbage dry matter production $\left(25,900 \mathrm{~kg} \mathrm{ha}^{-1}\right)$ and utilization efficiency (82\%). 


\section{INTRODUÇÃO}

A utilização de pastagens como recurso forrageiro para alimentação de ruminantes vem crescendo em importância na pecuária nacional e internacional por proporcionar um alimento de boa qualidade a baixos custos, competindo, com vantagem, com produções baseadas na utilização de resíduos industriais, grãos e suplementos volumosos como fonte de alimento. Para tornar a atividade realmente competitiva é necessário utilizar a pastagem de forma adequada. Nesse sentido, são de fundamental importância estudos baseados na fisiologia e ecologia das plantas forrageiras.

O manejo do pastejo embasado nas características da planta e nas condições de ambiente tem resultado em grande desenvolvimento do setor pecuário em alguns países de clima temperado. Centros de pesquisa tidos como desenvolvidos naqueles países têm realizado estudos dessa natureza há mais de 50 anos, sendo essa a marca registrada da pesquisa em pecuária. Nos países de clima tropical, os estudos são basicamente fundamentados em intervalos de descanso, taxas de lotação e/ou intensidade de corte/pastejo fixos, raramente respeitando a fisiologia da planta e sem o devido controle de características estruturais do dossel forrageiro (e. g., índice de área foliar), variáveischave para o correto manejo da desfolhação e uso da forragem produzida. Como conseqüência, o desempenho das pastagens é muito variável e inconsistente, resultando num elevado grau de insatisfação por parte de produtores e técnicos do setor. A necessidade de intensificar o uso de pastagens direciona, obrigatoriamente, os pesquisadores a dar nova ênfase e enfoque aos estudos com plantas forrageiras tropicais, assumindo um caráter sistêmico e multidisciplinar característico desse tipo de atividade. 


\section{REVISÃO DE LITERATURA}

\subsection{O processo de rebrotação em plantas forrageiras e a produção de forragem}

A filosofia de manejo de pastagens fundamentada em parâmetros fisiológicos e ecológicos das plantas forrageiras foi difundida em países de clima temperado desde a década de 50, com estudos realizados com azevém perene (Lolium perene L.).

Em estudos de Brougham (1955) foi determinada a natureza da curva de rebrotação de azevém e trevo branco (Trifolium repens L.) em pastos com desfolhações sucessivas. A curva apresenta três fases distintas. Na primeira fase, as taxas de acúmulo líquido de forragem aumentam exponencialmente com o tempo. Esta fase é altamente influenciada pelas reservas orgânicas da planta, disponibilidade de fatores de crescimento e área residual de folhas (Brougham, 1957). A segunda fase apresenta taxas de acúmulo líquido constantes. Nessa fase, o processo de competição inter e intraespecífica adquire caráter mais relevante, principalmente quando o dossel se aproxima da completa interceptação da luz incidente. Na terceira fase, inicia-se a queda das taxas de acúmulo líquido, causada pela redução na taxa de crescimento e pelo aumento na senescência de folhas, provocada pelo sombreamento (Hodgson et al., 1981).

Brougham (1955) verificou a necessidade de estudar a influência da intensidade em relação à frequiência de desfolhação após observar que a intensidade de corte alterava a fase inicial da curva de acúmulo. Esse mesmo autor (Brougham, 1956) estudou a influência da intensidade de desfolhação sobre as taxas de acúmulo subseqüentes e interceptação luminosa em campos de azevém perene consorciado com trevo branco sob corte. $\mathrm{O}$ autor verificou que as taxas de acúmulo do azevém estavam relacionadas à área foliar e à porcentagem de luz interceptada pelo dossel forrageiro. $\mathrm{O}$ acúmulo atingia uma 
taxa máxima constante que era mantida enquanto existia área foliar suficiente para interceptar quase toda a luz incidente. Outra conclusão foi que uma maior intensidade de desfolhação exigia um tempo mais prolongado de recuperação, pois a primeira fase da rebrotação estendia-se por um período maior. Contudo, a produção máxima atingida na curva de crescimento era a mesma de campos cortados menos intensamente.

Após constatação da interação entre intensidade e frequiência de corte sobre o manejo das plantas forrageiras, Brougham (1959) passou a estudar o efeito da combinação entre freqüência e intensidade de desfolhação em áreas pastejadas. Nesse estudo, o autor confirmou também a necessidade de manejar áreas sob pastejo através da combinação entre intensidade e freqüência de desfolhação.

Wilson at al. (1961) e Donald ${ }^{1}$ citado por Marshall (1987), quantificaram a luz que era interceptada pelo dossel de azevém perene mencionada por Brougham (1960). Os autores encontraram redução na podução total de forragem dos pastos quando estes eram desfolhados com menos de $95 \%$ de interceptação da luz incidente. No entanto, existem estudos controversos na literatura indicando que o acúmulo líquido de forragem em pastos de azevém perene pode aumentar (Mitamura, 1972) ou até mesmo diminuir (Taiton, 1974) após 95\% de interceptação luminosa. Korte et al. (1982) estudaram o comportamento do crescimento de azevém perene avaliando duas intensidades de desfolhação associadas a duas frequiências correspondentes ao intervalo de tempo para ocorrência de $95 \%$ de interceptação luminosa (IL) pelo dossel e duas semanas depois de atingido esse valor. Os autores concluíram que para a fase de desenvolvimento vegetativo, a frequiência de desfolhação no ponto onde o dossel atingia 95\% de IL era a mais indicada. Contudo, alertaram para a necessidade de cautela no uso dessa freqüência quando a planta encontrava-se em estádio de desenvolvimento reprodutivo devido a abertura do dossel forrageiro por causa do crescimento de hastes e maior penetração de luz no mesmo.

Quando o dossel atinge 95\% de IL as folhas inferiores passam a ser totalmente sombreadas. A ausência de luz numa folha induz uma diminuição em sua atividade

\footnotetext{
${ }^{1}$ DONALD, C.M.. Competition for light in crops and pastures. In:. Milthorpe, F.L, Mechanisms in biological competition. University Press, Cambrigde, p. 283-313. 1961. (Symposium of the Society for Experimental Biology, 15).
} 
fotossintética e esta entra no ponto de compensação (passa da condição de fonte de fotoassimilados para a condição de dreno). A partir desse ponto, as taxas de fotossíntese e respiração do dossel tornam-se muito próximas. Este é considerado o índice de área foliar ótimo, onde a taxa de acúmulo de massa seca do pasto atinge um máximo. Aumentos subseqüentes em índice de área foliar reduzem a taxa de acúmulo do pasto em função do aumento nas taxas de respiração, resultantes de um aumento na quantidade de tecidos sem função fotossintética (senescentes) (Donald ${ }^{1}$ ).

Todavia, não é exclusivamente a quantidade de folhas (área foliar) que tem grande efeito sobre a interceptação luminosa e, conseqüentemente, sobre o potencial fotossintético do dossel forrageiro. $\mathrm{O}$ arranjo espacial da área foliar dentro do dossel também é importante. Plantas com folhas dispostas horizontalmente interceptam mais luz com índice de área foliar menor que plantas com folhas eretas. Como resultado, comunidades com folhas horizontais são mais produtivas em condições de intensidade luminosa mais baixa ou, então, quando cortadas mais freqüientemente, enquanto que aquelas com folhas mais eretas são mais produtivas em condições de luminosidade mais elevada ou quando cortadas menos freqüentemente (Rhodes, 1973). Existem, portanto, interações, primeiro em nível de partes de um perfilho individual, depois em nível de comunidade de perfilhos, que determinam o acúmulo líquido de forragem. $\mathrm{O}$ acúmulo líquido pode ser definido como o resultado do balanço entre a taxa de crescimento de novos tecidos e a taxa de perdas dos tecidos "velhos" por senescência e decomposição. Dessa forma, o crescimento representa o potencial de produção da planta enquanto que a senescência e a decomposição podem representar a ineficiência do processo de colheita (Hodgson et al., 1981).

Os processos de crescimento e senescência de tecidos podem ser inicialmente discutidos em nível de perfilho. Após seu aparecimento, o perfilho passa a diferenciar-se e expandir folhas e alongar haste a uma velocidade determinada por fatores de ambiente, nutricionais e genéticos. $\mathrm{O}$ estudo que engloba o processo de crescimento e senescência de partes da planta é chamado morfogênese. Chapman \& Lemaire (1993) definiram a morfogênese de plantas como sendo a dinâmica de geração e expansão de partes das

\footnotetext{
${ }^{1}$ Citação no rodapé da página 3.
} 
plantas no espaço, podendo ser descrito em termos de taxas de aparecimento de novos órgãos (organogênese) e taxas de expansão, senescência e decomposição de tecidos. Em pastagens onde somente folhas são produzidas, a morfogênese é função de três características principais: aparecimento de folhas, alongamento de folhas e longevidade da folha. Entretanto, plantas forrageiras tropicais apresentam crescimento de hastes no período vegetativo (Da Silva \& Pedreira, 1997) razão qual é necessário considerar-se as taxas de alongamento e senescência de hastes como parte do conjunto de variáveis que compõem o estudo da morfogênese dessas plantas.

O crescimento de hastes propicia melhor iluminação no perfil do dossel favorecendo um aumento no tempo de vida das folhas e no número de folhas vivas por perfilho (Chapman \& Lemaire, 1993). Porém, o número de folhas que permanecem vivas no perfilho é determinado geneticamente, sendo por volta de três por perfilho para azevém perene (Hodgson, 1990) e oito para Coastcross (Cynodon ssp cv. coastcross-1) (Carnevalli \& Da Silva, 1999). Para o capim-Mombaça, o número de folhas vivas por perfilho relatado por Santos (1997) é de 5 a 6 . O número de folhas vivas por perfilho corresponde à longevidade das folhas expressa em número de intervalos de aparecimento. Em perfilhos individuais, o intervalo de tempo entre o aparecimento de duas folhas sucessivas é chamado filocrono, sendo a taxa de aparecimento de folhas a razão inversa do filocrono ( $\mathrm{TAF}=1 /$ filocrono). Sendo assim, uma vez estabelecido o número de folhas por perfilho da espécie, inicia-se uma sucessão de folhas caracterizada pelo início da senescência da folha mais velha a cada nova folha que aparece. Para azevém perene esse ponto coincide com $95 \%$ de IL do dossel forrageiro, ou seja, quando o pasto se encontra com 3 a $4 \mathrm{~cm}$ de altura e índice de área foliar de 2 a 4, variando conforme a estação do ano (Hodgson, 1990). Em pastos de Tifton-85 (Cynodon spp.) isso acontece quando o dossel atinge cerca de $15 \mathrm{~cm}$ de altura e índice de área foliar variando entre 1,5 e 2,7 (Fagundes et al., 1999; Fagundes et al., 2001; Pinto et al., 2001).

Atingido o ponto de máxima taxa média de acúmulo líquido de forragem, os fatores de crescimento passam a ser limitantes dentro do dossel forrageiro, acentuandose o processo de competição entre os perfilhos. $O$ fator de maior competição, sob condições ótimas, é a luz. Em comunidades de plantas, inicia-se o processo de morte de 
perfilhos. Os perfilhos surgem, crescem, aumentam em tamanho e promovem um "autodesbaste" em perfilhos mais fracos, localizados em pontos mais próximos do nível do solo, onde há baixa luminosidade. Quanto maior o tamanho do perfilho, menos perfilhos são mantidos na área (Hodgson,1990).

Muitos fatores afetam o perfilhamento das plantas forrageiras. De acordo com Langer (1979), a produção de perfilhos é controlada pela disponibilidade de água, luz, temperatura, nutrientes (principalmente nitrogênio e, em menor escala, fósforo e potássio) e pelo estádio de desenvolvimento da planta (reprodutivo ou vegetativo). A ação de todos esses fatores em conjunto determina o aparecimento e a morte de perfilhos que, segundo Langer (1956), acontece em todos os meses do ano. A perenidade de plantas individuais, e conseqüientemente do pasto, depende da capacidade de substituição dos perfilhos mortos, que também é afetada pelos picos estacionais de morte e aparecimento, especialmente aqueles associados com eventos de florescimento. Se a substituição de perfilhos falhar, a planta morre. Ou ainda, se a utilização do pasto continuar incorreta e a morte de perfilhos for consistentemente maior que o aparecimento, o pasto entra em processo de degradação (Marshall,1987).

Idealmente, o objetivo da produção animal em pastagem é obter a melhor resposta animal, mantendo cada vez mais produtiva a fonte de alimento (perenização). Para aumentar a produtividade das plantas forrageiras são necessárias práticas estratégicas de colheita em que a intensidade e a frequiência de corte ou pastejo reduzam ao mínimo o tempo que o pasto leva para atingir a interceptação luminosa completa. Essa combinação deve ser encontrada para cada espécie a ser manejada, respeitando a sua fenologia e fisiologia (Marshall,1987).

Estudos que determinem as combinações mais adequadas entre intensidade e freqüência de pastejo em plantas tropicais são ainda escassos. As plantas tropicais apresentam um grande potencial de produção, porém, em geral, não há uma estratégia de desfolhação consistente que permita a expressão desse potencial, uma vez que os pastos passam por um processo de redução gradativa de produtividade e, inevitavelmente, caminham para a degradação em curto período de tempo. 


\subsection{O capim-Mombaça}

A espécie forrageira Panicum maximum apresenta um dos maiores potenciais de produção de massa seca em ambientes subtropicais e tropicais que se conhece. Com base nesse fato, um grande número de cultivares tem sido lançado como Tobiatã, Tanzânia, Centenário, Mombaça, Vencedor entre outros. Todas essas variedades são lançadas com a mesma recomendação de utilização do capim Colonião, o cultivar mais tradicional e conhecido da espécie. Contudo, existem diferenças morfológicas, fisiológicas e fenológicas entre os cultivares que devem ser criteriosamente estudadas para determinação de combinações entre frequiência e intensidade de pastejo específicas para cada planta forrageira.

O cultivar Mombaça foi lançado pela EMBRAPA- Centro Nacional de Pesquisa de Gado de Corte (CNPGC), de Campo Grande, MS, em 1993. O cultivar foi classificado como BRA-006645 e coletado próximo de Korongue, na Tanzânia, em 1967. Trata-se de uma planta ereta e cespitosa com altura média de 1,65 m. As folhas são quebradiças, com largura média de 3,0 cm e sem cerosidade. As lâminas apresentam poucos pêlos (duros e curtos), principalmente na face superior. As bainhas são glabras. Os colmos são levemente arroxeados. A inflorescência é uma panícula com ramificações primárias longas e secundárias longas apenas na base. As espiguetas são glabras, uniformemente distribuídas, e arroxeadas em aproximadamente $1 / 3$ da superfície externa. O verticilo normalmente apresenta micropilosidade. Apresenta alta produtividade de forragem $165,3 \mathrm{t} \mathrm{ha}^{-1}$ ano $^{-1}$ de massa verde e $32,9 \mathrm{t} \mathrm{ha}^{-1}$ ano $^{-1}$ de massa foliar seca. Apresenta alta porcentagem de folhas (cerca de $80 \%$ ), sendo que no inverno atinge cerca de $87 \%$ de folhas. Com baixo nível de fertilização pode produzir até $75 \%$ da produção obtida com uso de fertilizantes. Apresenta em torno de $10 \%$ da produção anual durante a seca. Os teores de proteína bruta nas folhas e colmos giram em torno de 13 e $10 \%$, respectivamente, e a produção de sementes ocorre entre os meses de abril e junho (Savidan, 1990).

Barbosa et al. (1996) obtiveram 7,2 t MS ha ${ }^{-1}$ com $11,1 \%$ de proteína bruta no verão e 2,4 $\mathrm{t} \mathrm{ha}^{-1}$ de MS com 10,4\% de proteína bruta no inverno. A produção de 
forragem obtida por Machado et al. (1997) foi de 20 a $21 \mathrm{t} \mathrm{ha}^{-1}$ ano $^{-1}$ de MS sendo que as parcelas cortadas mais intensamente proporcionaram as produções mais elevadas.

Avaliando o capim-Mombaça sob pastejo, Herling et al. (1998 a) testaram dois períodos de descanso (35 e 42 dias) e três intensidades de pastejo (1.000, 2.000 e 3.000 $\mathrm{kg} \mathrm{ha}^{-1}$ de MS residual). Os autores concluíram que o período de descanso deveria ser melhor ajustado para cada época do ano e que 42 dias era um tempo de descanso muito longo, pois houve aumento na quantidade de material fibroso e nas perdas por pastejo. Santos (1997) afirmou que para as épocas de maior disponibilidade de fatores de crescimento um período de descanso inferior a 28 dias seria o mais indicado para o capim-Mombaça.

O capim-Mombaça é uma planta com um potencial de produção condizente com taxas de lotação de $1,8 \mathrm{UA} \mathrm{ha}^{-1}$ com um ganho de peso de cerca de $720 \mathrm{~kg} \mathrm{ha}^{-1}$ ano $^{-1}$ (IAPAR - Paranavaí), a 5,2 UA ha ${ }^{-1}$ (Jank, 1994) e pode atingir, segundo Corsi \& Santos (1995), de 12 a $15 \mathrm{UA} \mathrm{ha}^{-1}$ ano $^{-1}$ no verão e 3 a $4 \mathrm{UA} \mathrm{ha}^{-1}$ ano $^{-1}$ no inverno, proporcionando um ganho de peso de 1.600 a $2.000 \mathrm{~kg} \mathrm{ha}^{-1} \mathrm{ano}^{-1}$.

Para obter elevados índices de produtividade animal é necessário conhecer aspectos morfofisiológicos e ecológicos da pastagem. Santos (1997) iniciou estudos nesse sentido avaliando respostas de renovação de tecidos e perfilhamento em plantas de capim Tanzânia e Mombaça. A taxa de alongamento de folhas sofreu variação de até 1,0 cm perfilho ${ }^{-1}$ dia $^{-1}$ entre os intervalos de pastejo de 28,38 e 48 dias. De maio a julho houve uma drástica redução na taxa de alongamento foliar ocasionada pela redução dos fatores de crescimento e pelo florescimento. A taxa de senescência aumentou com o aumento do período de descanso, sendo que para 28 dias essa taxa representou cerca de $15 \%$ da taxa de alongamento foliar. Houve tendência de queda do acúmulo líquido com o aumento do intervalo entre os pastejos, indicando que de novembro a abril a planta deveria ser utilizada mais freqüentemente. Contudo, Barbosa et al. (1997) não obtiveram senescência de folhas antes de 35 dias de rebrotação durante o verão.

Santos (1997) observou redução na senescência de abril a maio e justificou isso com o fato de a planta estar iniciando o processo reprodutivo, quando há alongamento de hastes e a luz penetra até regiões mais próximas do nível do solo. Nesse período, houve 
redução no número de perfilhos por unidade de área e aumento concomitante de tamanho causado pelo florescimento. Houve aumento na altura do dossel forrageiro entre novembro e abril, o que foi relacionado à variação dos fatores de crescimento ao longo dos meses e os períodos de descanso utilizados terem sido fixos e determinados $a$ priori. Para os meses onde há maior disponibilidade de fatores de crescimento, a planta cresce segundo taxas mais aceleradas aumentando, principalmente, o comprimento das hastes, que são evitadas pelos animais, provocando o aumento da altura do dossel forrageiro, além de estarem sendo colhidas num estádio de desenvolvimento fenológico mais avançado.

Outro ponto de importância sobre o capim-Mombaça é o hábito de perfilhamento. Barbosa et al. relataram que a emissão de perfilhos aumentou linearmente, normalmente até a terceira semana após o pastejo, sendo que na primavera todos os perfilhos surgiram na primeira semana após a desfolhação. Contudo, não se sabe qual é a importância dos perfilhos que surgem depois da primeira semana, nem qual seria a sua longevidade. Parece existir também uma participação considerável de perfilhos remanescentes de um pastejo na produção do ciclo de pastejo subseqüente (Barbosa et al., 1996). Porém, como nesses estudos as condições de dossel foram mantidas variáveis e sem um padrão pré-definido de controle, torna-se muito difícil entender como e com que intensidade esses eventos poderiam estar acontecendo e quais seriam suas implicações práticas potenciais. Sem exceção, em todos os trabalhos existentes na literatura sobre o capim-Mombaça, os autores concordam que há uma grande necessidade de estudos que esclareçam, de forma objetiva, qual é a maneira mais indicada de manejar o processo de pastejo e/ou colheita da forragem produzida.

Assim, o objetivo deste trabalho foi conhecer e descrever características básicas do dossel forrageiro e de componentes do crescimento do capim-Mombaça submetido a regimes de desfolhação intermitente caracterizados por duas metas de pós-pastejo (resíduos de 30 e $50 \mathrm{~cm}$ ) e duas metas de pré-pastejo (interceptação luminosa do dossel de 95 e $100 \%$ IL). 


\section{MATERIAL E MÉTODOS}

\subsection{Material}

\subsubsection{Espécie vegetal e local do experimento}

O experimento foi realizado com o capim da espécie Panicum maximum, Jacq. cv. Mombaça. A área utilizada faz parte do Sistema de Produção de Leite do Departamento de Biotecnologia Vegetal do Centro de Ciências Agrárias da Universidade Federal de São Carlos, situada no município de Araras, SP (Figura 1). As coordenadas geográficas aproximadas do local são $22^{\circ} 18^{\prime}$ de latitude sul, $47^{\circ} 23^{\prime}$ de longitude oeste e $611 \mathrm{~m}$ de altitude. As áreas de pastagem foram formadas em $1998 \mathrm{e} \mathrm{em}$ 2000 passaram por um processo de drenagem já que eram áreas facilmente alagáveis. A fase experimental correspondeu ao período de 8 de janeiro de 2001 a 23 de fevereiro de 2002, com duração de 411 dias. 


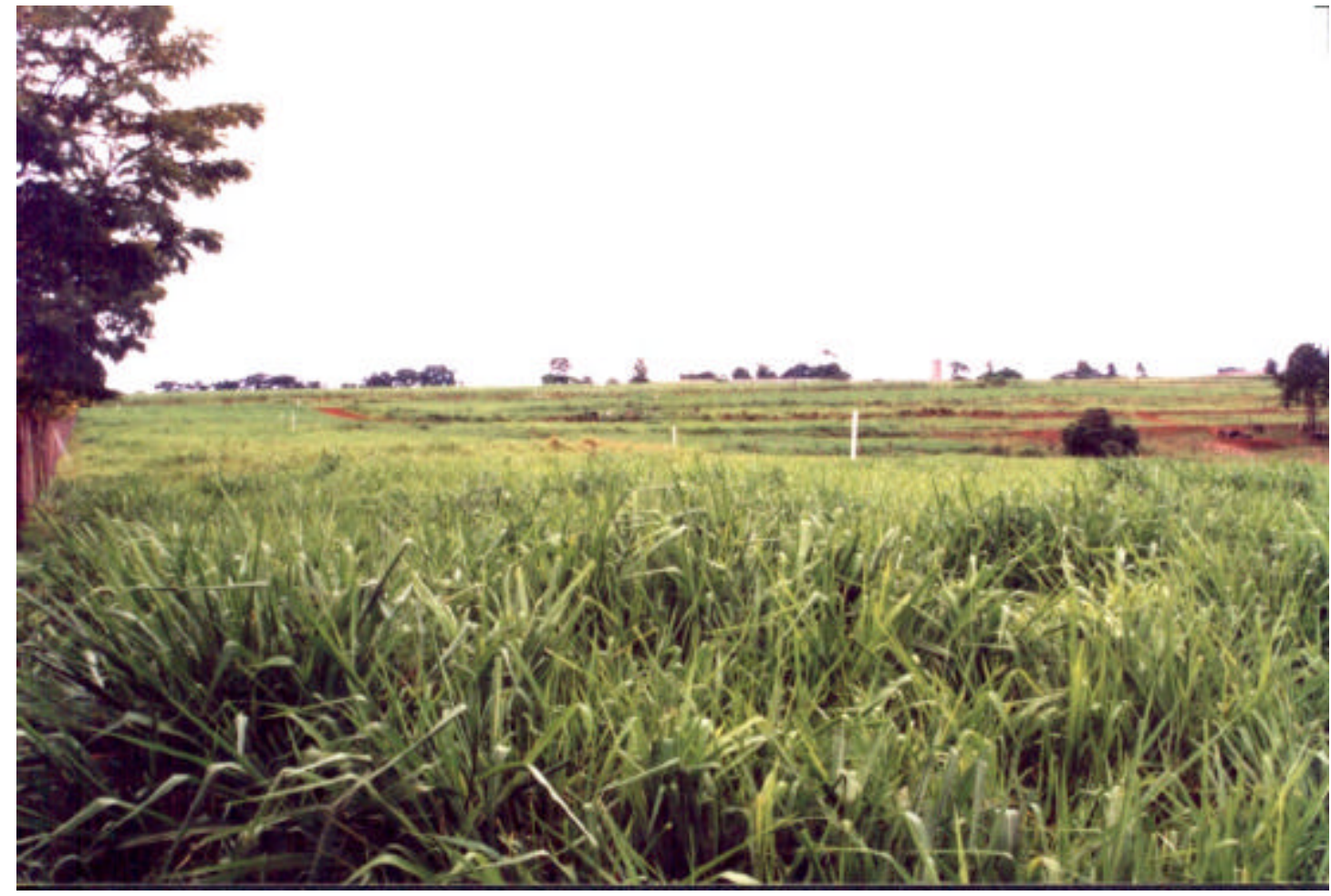

Figura 1- Vista geral da área experimental

\subsubsection{Dados climáticos}

Os dados climáticos referentes ao período experimental foram obtidos no Posto Meteorógico da Universidade Federal de São Carlos, campus de Araras, distante cerca de $500 \mathrm{~m}$ da área experimental. Foram obtidos os dados de temperatura (Figura 2), precipitação (Figura 3) e balanço hídrico (Figura 4) do período referente ao experimento e àmédia dos últimos 30 anos. 


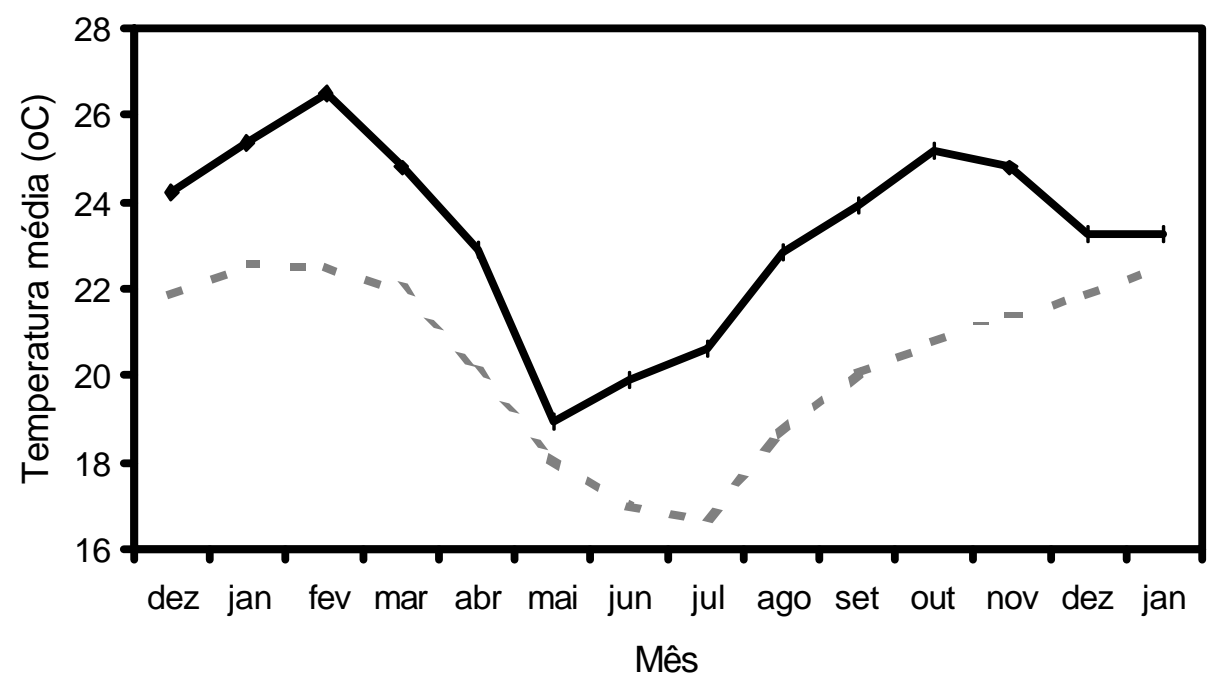

—-Período Experimental = - - Médias (30 anos)

Figura 2- Distribuição das temperaturas médias durante o período experimental e nos últimos 30 anos

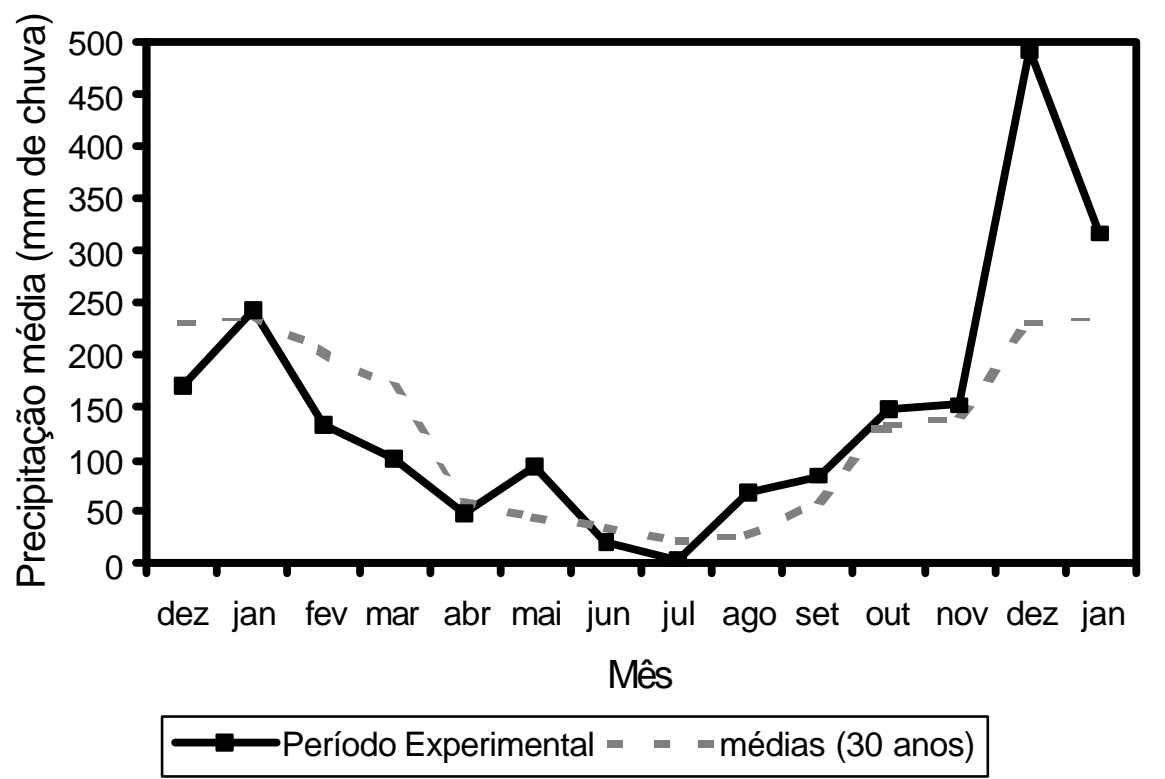

Figura 3- Distribuição da precipitação durante o período experimental e nos últimos 30 anos 


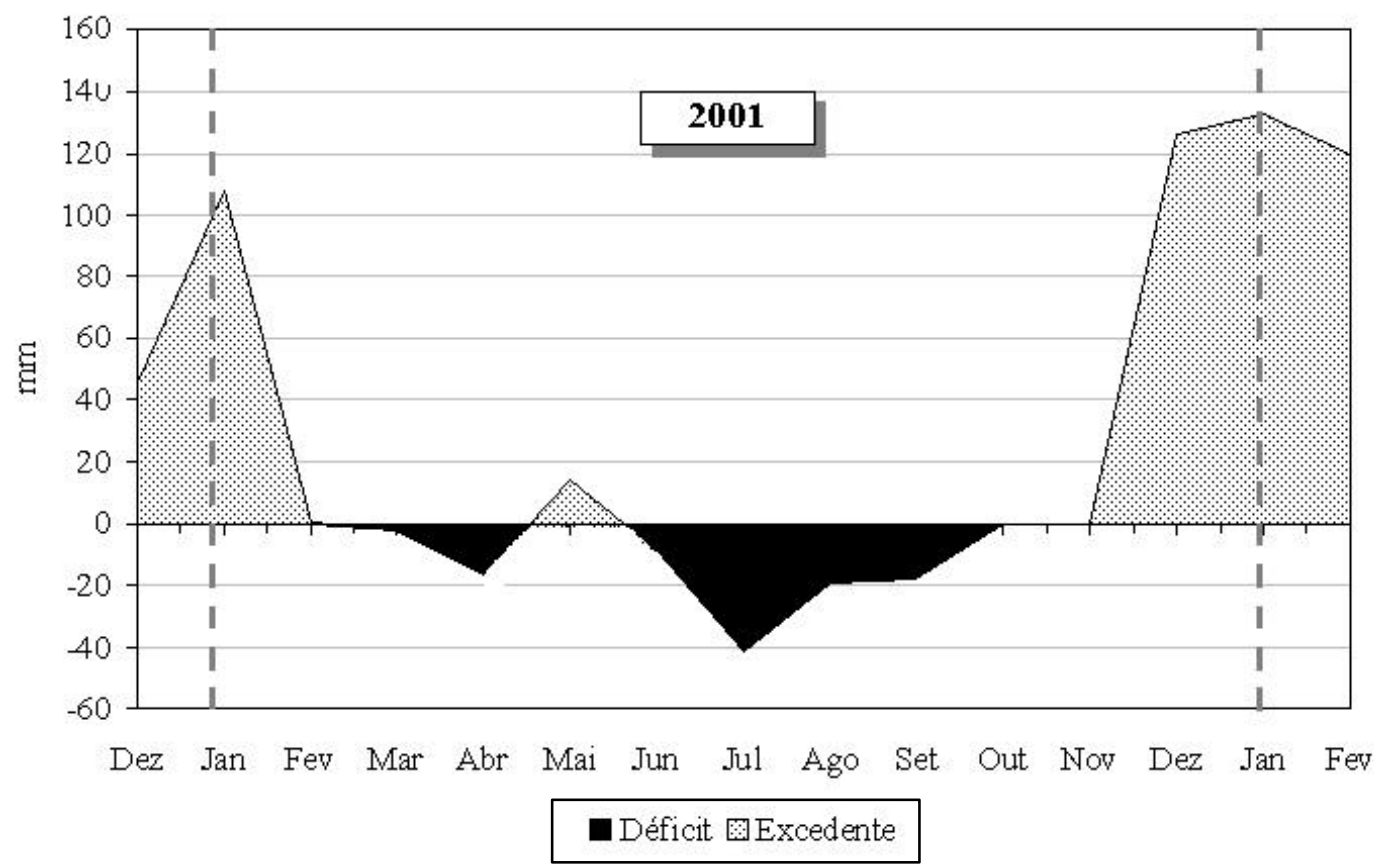

Figura 4 Balanço hídrico da área experimental de janeiro 2001 a fevereiro de 2002

\subsubsection{Solo}

As pastagens foram implantadas sobre um Argissolo Vermelho distrófico latossólico (PVd), conforme classificação do sistema da Embrapa (1999). Esse solo apresenta textura muito argilosa com horizonte A moderado e fertilidade mediana, conforme resultado de análise de terra apresentado na Tabela 1. Foram efetuadas amostragens em piquetes previamente selecionados para formação da área experimental com base no grau de homogeneidade do estande das plantas. Os piquetes foram então agrupados em blocos homogêneos em relação aos níveis de fósforo e saturação por bases. O piquete 5, relativo ao tratamento 30/95 (Bloco II), recebeu $250 \mathrm{~kg} \mathrm{ha}^{-1}$ de superfosfato simples com a finalidade de elevar o nível de fósforo do solo para $13 \mathrm{mg}$ $\mathrm{dm}^{-3}$. 
Tabela 1. Resultado da análise de terra realizada em setembro de 2000 nos piquetes experimentais de capim-Mombaça

\begin{tabular}{|c|c|c|c|c|c|c|c|c|c|c|}
\hline Piquete & $\mathrm{P}$ & $\begin{array}{c}\mathrm{MO} \\
\left(\mathrm{g} \mathrm{dm}^{-3}\right)\end{array}$ & $\begin{array}{c}\mathrm{pH} \\
\left(\mathrm{CaCl}_{2}\right)\end{array}$ & $\mathrm{K}$ & $\mathrm{Ca}$ & $\begin{array}{r}\mathrm{Mg} \\
\quad(\mathrm{m}\end{array}$ & $\begin{array}{l}\mathrm{H}+\mathrm{Al} \\
\left.\mathrm{ol}_{\mathrm{c}}\right)\end{array}$ & $S$ & $\mathrm{~T}$ & $\begin{array}{l}\mathrm{V} \\
(\%)\end{array}$ \\
\hline \multicolumn{11}{|c|}{ Bloco I } \\
\hline 1 & 7 & 29 & 5,1 & 1,8 & 26 & 15 & 33 & 43,1 & 75,6 & 57 \\
\hline 2 & 9 & 27 & 5,2 & 1,4 & 28 & 13 & 33 & 42,5 & 75,0 & 57 \\
\hline 3 & 8 & 24 & 4,7 & 1,6 & 21 & 12 & 42 & 35,2 & 77,5 & 45 \\
\hline 4 & 7 & 25 & 5,1 & 0,9 & 23 & 11 & 33 & 35,4 & 67,9 & 52 \\
\hline \multicolumn{11}{|c|}{ Bloco II } \\
\hline 5 & 8 & 25 & 5,4 & 2,5 & 22 & 16 & 26 & 40,3 & 66,6 & 60 \\
\hline 6 & 19 & 32 & 5,8 & 3,7 & 30 & 19 & 22 & 52,7 & 75,2 & 70 \\
\hline 7 & 13 & 35 & 5,5 & 2,7 & 39 & 18 & 29 & 60,0 & 89,2 & 67 \\
\hline 8 & 13 & 35 & 5,3 & 2,1 & 34 & 13 & 33 & 49,6 & 82,1 & 60 \\
\hline \multicolumn{11}{|c|}{ Bloco III } \\
\hline 9 & 5 & 32 & 5,2 & 1,9 & 22 & 12 & 34 & 35,8 & 70,1 & 51 \\
\hline 10 & 7 & 37 & 5,3 & 1,9 & 24 & 15 & 31 & 40,4 & 71,3 & 57 \\
\hline 11 & 6 & 33 & 5,1 & 2,1 & 26 & 14 & 38 & 42,5 & 80,6 & 53 \\
\hline 12 & 6 & 40 & 5,6 & 2,6 & 29 & 17 & 28 & 48,9 & 76,6 & 64 \\
\hline \multicolumn{11}{|c|}{ Bloco IV } \\
\hline 13 & 6 & 37 & 5,4 & 1,1 & 44 & 14 & 33 & 59,1 & 91,6 & 65 \\
\hline 14 & 8 & 38 & 5,8 & 2,3 & 45 & 18 & 25 & 64,6 & 89,6 & 72 \\
\hline 15 & 8 & 41 & 5,6 & 1,7 & 58 & 22 & 29 & 82,0 & 111,2 & 74 \\
\hline 16 & 8 & 37 & 5,5 & 1,2 & 40 & 18 & 28 & 59,5 & 87,2 & 68 \\
\hline
\end{tabular}




\subsection{Métodos}

\subsubsection{Tratamentos e delineamento experimental}

Os tratamentos experimentais corresponderam à combinação entre duas intensidades e duas frequiências de desfolhação. Uma desfolhação intensa, que visava uma maior utilização da forragem, foi caracterizada por um resíduo de $30 \mathrm{~cm}$ de altura, e uma desfolhação mais leniente, mais próxima da altura de resíduo normalmente utilizada por produtores, foi caracterizada pela altura de $50 \mathrm{~cm}$. Essas intensidades foram combinadas a duas frequiências de desfolhação, uma correspondente ao tempo necessário para que o dossel forrageiro atingisse um índice de área foliar (IAF) tal que permitisse que $95 \%$ da luz incidente fosse interceptada e outra correspondente à interceptação de cerca de $100 \%$ da luz incidente. A distribuição das unidades experimentais (piquetes) na área experimental (layout) é apresentada na Figura 5.

O delineamento experimental utilizado foi o de blocos completos casualizados, com os tratamentos em arranjo fatorial 2 x 2 e 4 repetições. Em setembro de 2000 os piquetes começaram a ser manejados de forma intermitente e com resíduo de $30 \mathrm{~cm}$ em toda a área experimental. Em dezembro foram implementados os resíduos de 30 e $50 \mathrm{~cm}$ em cada piquete de conformidade com o sorteio prévio dos tratamentos. Como não havia ainda o controle da frequiência de desfolhação dos pastos conforme o protocolo experimental e os mesmos eram pastejados seguindo um período fixo de descanso de cerca de 32 dias, houve dificuldade m manutenção dos resíduos propostos, o que levou à necessidade de algumas roçadas manuais após o primeiro pastejo em janeiro de 2001, quando do início do período experimental. Essas roçadas tiveram a finalidade de assegurar que as alturas de resíduo planejadas fossem geradas adequadamente no início do experimento não sendo mais realizadas durante todo o período experimental. As variações em altura do resíduo foram monitoradas a cada ciclo de pastejo e analisadas como variável-resposta do experimento. 


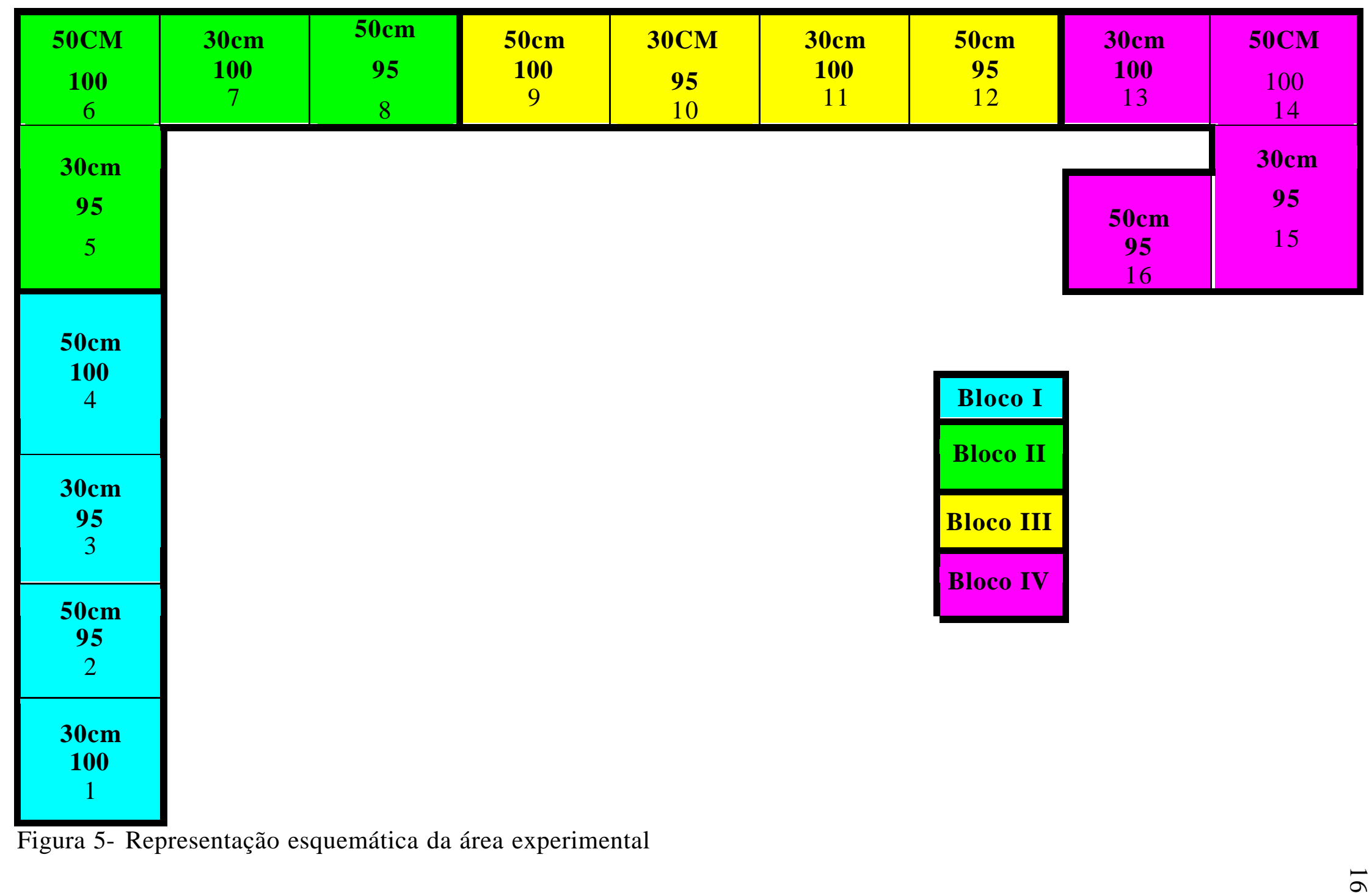




\subsubsection{Monitoramento das condições experimentais e adubação dos pastos}

O monitoramento da interceptação luminosa foi realizado na condição de póspastejo, a cada incremento de $20 \mathrm{~cm}$ na altura do dossel após o pastejo (alturas de 50, 70, $90 \mathrm{~cm}$ e em alguns tratamentos $110 \mathrm{~cm}$ ) e a cada dois dias à medida que a marca de $90 \%$ de IL era atingida, utilizando-se um aparelho analisador de dossel marca LI-COR modelo LAI 2000 (LI-COR, Lincoln, Nebraska, EUA). Foram utilizadas 6 estações de leitura (amostragem) por unidade experimental, compostas de 5 leituras cada, totalizando 30 pontos de leitura por unidade experimental. As leituras eram realizadas no nível do solo com uma leitura acima do nível do dossel no início de cada estação. Esse número de leituras foi obtido através de simulações do número de estações necessárias em uma pré-avaliação, sendo que 30 resultou em repetibilidade e precisão satisfatórias dos resultados.

As unidades experimentais receberam adubações nitrogenadas após cada pastejo, diferenciadas por ciclo de pastejo, totalizando $195 \mathrm{~kg} \mathrm{ha}^{-1}$ de nitrogênio ao final do experimento. Como o intervalo entre pastejos não era fixo e a condição de entrada dos animais no pasto era também variável, essa quantidade fi dividida por pastejo conforme o período de descanso resultante de cada tratamento, de tal forma que uma quantidade relativamente uniforme fosse aplicada por mês (Tabela 2). 
Tabela 2. Quantidade de $\mathrm{N}\left(\mathrm{kg} \mathrm{ha}^{-1}\right)$ aplicada por adubação em cada repetição e a respectiva data de aplicação* durante o período experimental

\begin{tabular}{|c|c|c|c|c|c|c|c|c|}
\hline Trat. ** & Data & $\mathrm{kg} \mathrm{ha}^{-1}$ & Data & $\mathrm{kg} \mathrm{ha}^{-1}$ & Data & $\mathrm{kg} \mathrm{ha}^{-1}$ & Data & $\mathrm{kg} \mathrm{ha}^{-}$ \\
\hline \multirow[t]{11}{*}{$30 / 95$} & \multicolumn{2}{|c|}{ Bloco I } & \multicolumn{2}{|c|}{ Bloco II } & \multicolumn{2}{|c|}{ Bloco III } & \multicolumn{2}{|c|}{ Bloco IV } \\
\hline & $11 / 01$ & 15 & $20 / 01$ & 15 & $27 / 01$ & 15 & $16 / 01$ & 15 \\
\hline & $14 / 02$ & 30 & $17 / 02$ & 30 & 03/03 & 30 & $16 / 02$ & 15 \\
\hline & $21 / 04$ & 50 & $21 / 03$ & 30 & 08/04 & 50 & $22 / 03$ & 30 \\
\hline & $19 / 07$ & 0 & $10 / 04$ & 50 & $18 / 07$ & 60 & $12 / 04$ & 50 \\
\hline & $07 / 11$ & 60 & $11 / 06$ & 0 & $04 / 11$ & 0 & $11 / 06$ & 0 \\
\hline & $28 / 11$ & 20 & $29 / 10$ & 30 & $03 / 12$ & 20 & $10 / 10$ & 45 \\
\hline & $31 / 12$ & 20 & $27 / 11$ & 20 & $23 / 12$ & 20 & $03 / 11$ & 20 \\
\hline & & & $30 / 12$ & 20 & & & $23 / 11$ & 0 \\
\hline & & & & & & & $12 / 12$ & 20 \\
\hline & & & & & & & 02/01/02 & 0 \\
\hline \multirow[t]{7}{*}{$30 / 100$} & \multicolumn{2}{|c|}{ Bloco I } & \multicolumn{2}{|c|}{ Bloco II } & \multicolumn{2}{|c|}{ Bloco III } & \multicolumn{2}{|c|}{ Bloco IV } \\
\hline & 09/01 & 15 & $19 / 01$ & 15 & $27 / 01$ & 15 & $18 / 01$ & 15 \\
\hline & $22 / 02$ & 30 & $21 / 02$ & 30 & $10 / 03$ & 30 & $11 / 03$ & 30 \\
\hline & $07 / 04$ & 50 & 03/04 & 50 & $23 / 04$ & 50 & $26 / 04$ & 50 \\
\hline & $16 / 07$ & 0 & $18 / 07$ & 0 & 20/08 & 0 & $15 / 11$ & 60 \\
\hline & $27 / 11$ & 60 & $20 / 11$ & 60 & $20 / 11$ & 60 & 12/01/02 & 40 \\
\hline & 08/01/02 & 40 & 03/01/02 & 40 & $22 / 12$ & 40 & & \\
\hline \multirow[t]{10}{*}{$50 / 95$} & \multicolumn{2}{|c|}{ Bloco I } & \multicolumn{2}{|c|}{ Bloco II } & \multicolumn{2}{|c|}{ Bloco III } & \multicolumn{2}{|c|}{ Bloco IV } \\
\hline & 09/01 & 15 & 20/01 & 15 & $27 / 01$ & 15 & $17 / 01$ & 15 \\
\hline & $02 / 02$ & 15 & $17 / 02$ & 30 & $24 / 02$ & 30 & $08 / 02$ & 15 \\
\hline & $24 / 02$ & 0 & $23 / 03$ & 30 & $19 / 04$ & 50 & $06 / 03$ & 30 \\
\hline & $24 / 03$ & 30 & $21 / 04$ & 50 & $16 / 10$ & 60 & $03 / 04$ & 50 \\
\hline & $26 / 04$ & 50 & $17 / 07$ & 0 & $14 / 11$ & 20 & $27 / 04$ & 0 \\
\hline & $01 / 11$ & 45 & $06 / 10$ & 30 & $05 / 12$ & 20 & $04 / 10$ & 45 \\
\hline & $28 / 11$ & 20 & $29 / 10$ & 0 & $22 / 12$ & 0 & $27 / 10$ & 0 \\
\hline & $21 / 12$ & 20 & $05 / 12$ & 20 & & & $03 / 12$ & 20 \\
\hline & & & $31 / 12$ & 20 & & & $27 / 12$ & 20 \\
\hline \multirow[t]{7}{*}{$50 / 100$} & \multicolumn{2}{|c|}{ Bloco I } & \multicolumn{2}{|c|}{ Bloco II } & \multicolumn{2}{|c|}{ Bloco III } & \multicolumn{2}{|c|}{ Bloco IV } \\
\hline & $13 / 01$ & 15 & 20/01 & 15 & $27 / 01$ & 15 & $17 / 01$ & 15 \\
\hline & $14 / 02$ & 30 & $19 / 02$ & 30 & 05/03 & 30 & $12 / 02$ & 15 \\
\hline & $30 / 04$ & 50 & $25 / 03$ & 30 & $23 / 04$ & 50 & $28 / 03$ & 30 \\
\hline & $12 / 11$ & 60 & $24 / 04$ & 50 & $05 / 11$ & 60 & $30 / 04$ & 50 \\
\hline & $22 / 12$ & 40 & $11 / 10$ & 30 & $10 / 12$ & 40 & $12 / 11$ & 45 \\
\hline & & & $28 / 11$ & 40 & & & $18 / 12$ & 40 \\
\hline
\end{tabular}

*Nitrogênio aplicado na forma de 20-05-20.

**Tratamento = resíduo $(\mathrm{cm}) /$ interceptação luminosa $(\%)$. 
Os pastejos foram realizados por vacas em lactação da raça holandesa. Contudo, os animais foram somente agentes desfoliadores, não tendo sido executado tipo algum de avaliação animal durante o período experimental.

\subsubsection{Avaliações}

As avaliações foram realizadas durante a fase de rebrotação e crescimento do pasto (período de descanso) de forma seqüencial e em pontos pré-determinados, ou seja, foram realizadas medições/contagens a cada $20 \mathrm{~cm}$ de incremento na altura média do dossel forrageiro a partir do resíduo, permitindo a caracterização de variações em estrutura do dossel, dos padrões de interceptação luminosa e da dinâmica de acúmulo de forragem. Com a finalidade de auxiliar no monitoramento da altura das parcelas experimentais, foram instaladas réguas indicadoras com marcação das alturas de interesse em vários pontos da parcela, de modo que era relativamente fácil a visualização do momento em que o dossel alcançava a altura média desejada de avaliação (Figura 6).

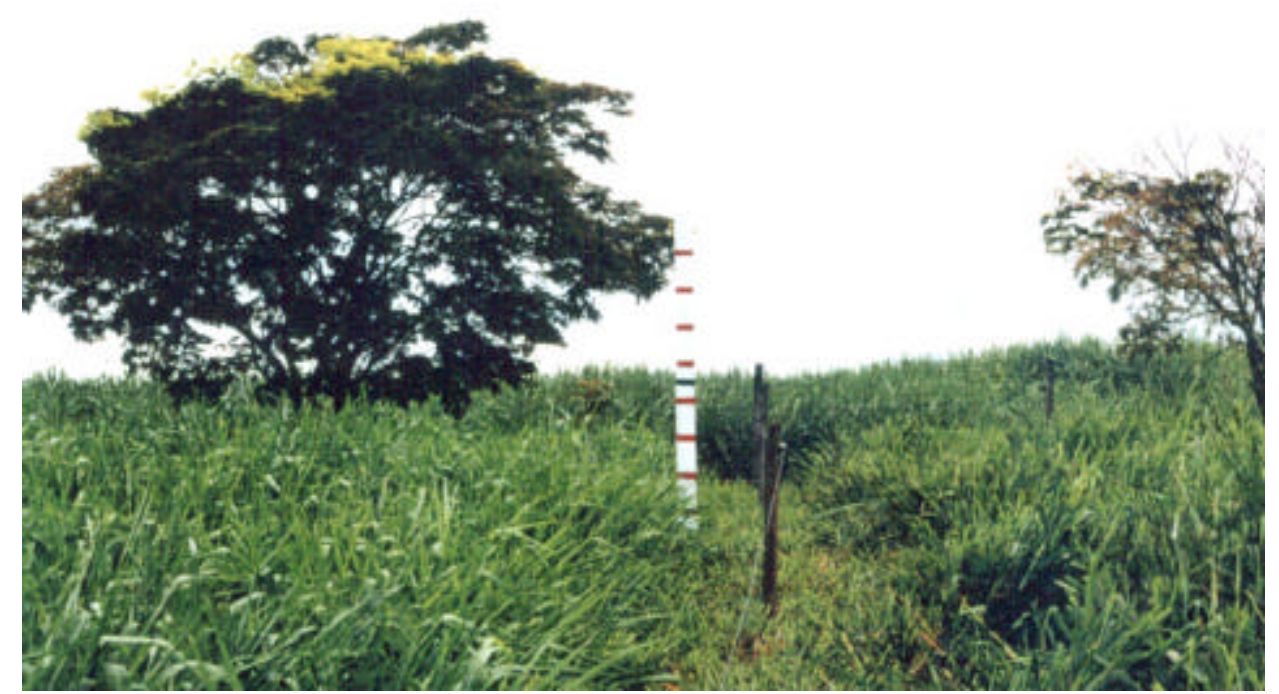

Figura 6- Vista da régua indicadora instalada entre as unidades experimentais para monitoramento da altura 
Após a constatação da proximidade da meta de altura para realização das avaliações planejadas, a altura efetiva do dossel forrageiro era medida em 16 pontos dentro de cada unidade experimental (Figura 7) por meio de régua de madeira de 2 metros graduada em centímetros. O percurso dentro de cada unidade experimental era feito de maneira sistemática (forma de "malha") para evitar possíveis desvios entre observadores (Figura 8). Em cada um dos 16 pontos de medição tomava-se a altura média do plano de folhas no horizonte visualizado acima do dossel forrageiro, mesmo quando os pastos encontravam-se em estádio reprodutivo e havia a existência de inflorescências.

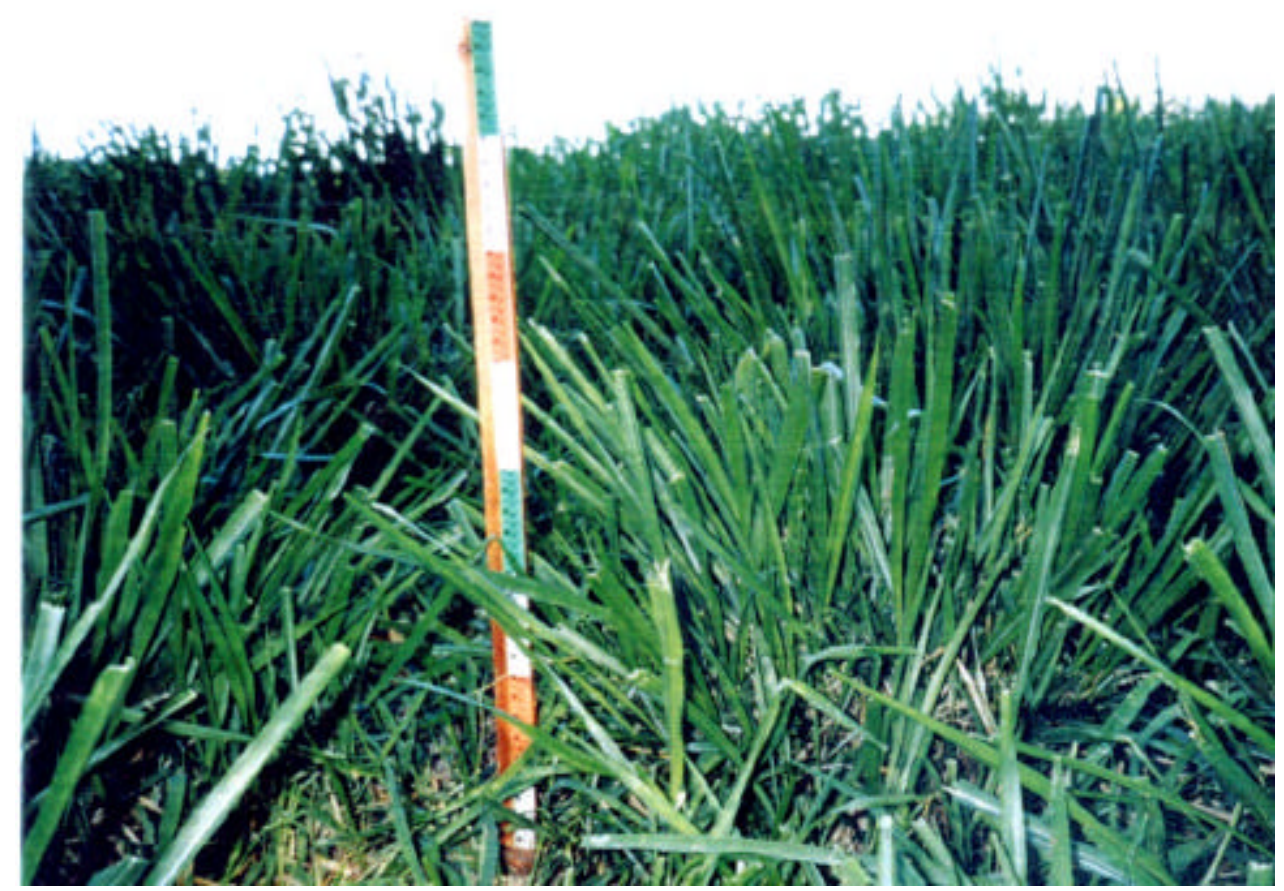

Figura 7- Medição de altura do dossel forrageiro dentro da unidade experimental 


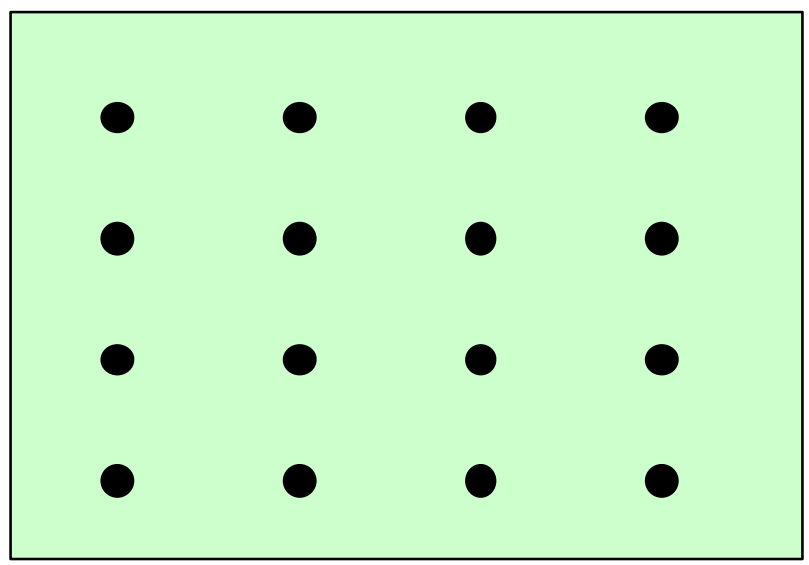

Figura 8- Percurso dentro da unidade experimental para medição de altura do dossel forrageiro

\subsubsection{Interceptação luminosa e características do dossel forrageiro}

As avaliações de interceptação luminosa, índice de área foliar e ângulo da folhagem foram realizadas nas alturas pré-determinadas (saída dos animais dos piquetes, incrementos de $20 \mathrm{~cm}$ na altura do dossel forrageiro durante a rebrotação e em prépastejo) com o analisador de dossel LI-COR modelo LAI 2000 (LI-COR, Lincoln, Nebraska, EUA) que permite amostragens rápidas e não destrutivas. Welles \& Norman (1991) descreveram o funcionamento do LAI 2000. O aparelho é constituído por uma unidade de controle e um sensor em formato de barra articulada. O sensor é composto por um conjunto de lentes tipo olho de peixe, que projeta uma imagem hemisférica de baixo para cima do dossel, através de detectores de sílica. A unidade de controle recebe e registra os dados do sensor e executa os cálculos necessários para determinação do índice de área foliar e do ângulo médio de inclinação da folhagem. A técnica consiste basicamente na combinação de uma medição do "brilho do sol", feita com o sensor nivelado acima do dossel, com uma segunda medição ou medições tomadas sob o dossel, no nível do solo. $\mathrm{Na}$ verdade, a medição que recebe o nome de índice de área foliar corresponde a um índice de área da folhagem, uma vez que o sensor registra todo 
material presente no dossel que faz sombra sobre a lente do aparelho. O ângulo da folhagem é um valor que indica a orientação da folhagem. Quando toda folhagem estiver na posição horizontal o valor do ângulo é $0^{\circ}$ e quando toda folhagem estiver em posição vertical esse valor é $90^{\circ}$ (Figura 9).

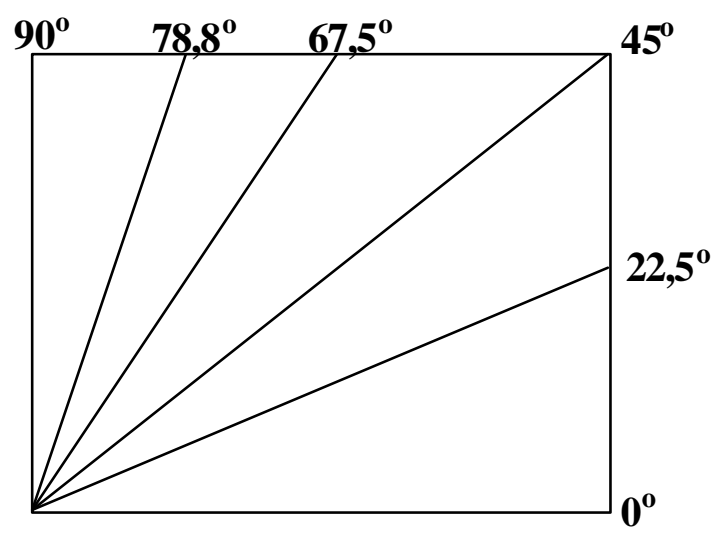

Figura 9- Representação ilustrativa de inclinações do ângulo da folhagem

Por ocasião da realização das avaliações foram efetuadas leituras em 6 pontos aleatórios de amostragem e representativos de cada parcela, sendo uma leitura acima do dossel e 5 no nível do solo por local de amostragem.

\subsubsection{Dinâmica do acúmulo de forragem}

No início de cada período de rebrotação, a partir do resíduo de cada tratamento, eram marcados 12 perfilhos por unidade experimental com auxílio de arames revestidos de plástico colorido (6 touceiras por parcela e 2 perfilhos por touceira). As avaliações foram realizadas por equipes específicas alocadas para cada bloco e mantidas de forma consistente durante todo o período experimental. As equipes foram previamente treinadas para padronização de procedimentos e padrões de julgamento visual. As avaliações foram realizadas a cada 4 dias na primavera e verão, a cada 7 dias no outono e a cada 15 dias no inverno, e compreendiam as seguintes medições: 
- Tamanho da pseudohaste ou haste: comprimento da base do perfilho (nível do solo para perfilhos basais ou inserção na haste mãe para perfilhos aéreos) até a lígula da última folha expandida.

- Tamanho das lâminas foliares: comprimento da lâmina medido da lígula até a ponta da folha. No caso de folhas em expansão, que ainda não haviam exposto sua lígula, o ponto de referência era a lígula da última folha expandida.

- Condição da folha: todas as lâminas foliares foram caracterizadas conforme a sua situação, podendo ser classificadas como intacta ou desfolhada adulta, em expansão ou em senescência.

- Senescência: consistia na medida do comprimento total da lâmina da folha senescente mais uma estimativa da proporção de material senescente do limbo foliar. No caso de hastes, a senescência foi caracterizada pela perda das folhas e morte dos tecidos da haste, não somente de bainhas.

- Número de folhas vivas: contagem do número de folhas verdes, não senescentes.

- Relação comprimento x massa: no último dia de avaliação (condição de prépastejo), os perfilhos eram cortados e levados para o laboratório onde eram medidos e dissecados separando-se hastes, folhas em expansão e folhas senescentes. Essas frações eram secas em estufa a $65^{\circ} \mathrm{C}$ e posteriormente quantificadas, obtendo-se a relação entre comprimento e massa dos componentes.

A partir dos dados de campo foram realizados os cálculos para determinação das seguintes variáveis respostas:

- Taxa de aparecimento de folhas: quociente entre o número médio de folhas por perfilho surgidas no período avaliado e número de dias do período (folhas perfilho $\left.^{-1} \mathrm{dia}^{-1}\right)$.

- Filocrono: inverso da taxa de aparecimento de folhas (dias folha ${ }^{-1}$ perfilho $^{-1}$ ).

- Taxa de alongamento de haste: variação média no comprimento da haste/pseudohaste durante o período de avaliação $\left(\mathrm{cm}_{\text {perfilho }}{ }^{-1} \mathrm{dia}^{-1}\right)$. 
- Taxa de expansão de folhas: variação média no comprimento da folha em expansão durante o período de avaliação ( $\mathrm{cm}$ perfilho ${ }^{-1} \mathrm{dia}^{-1}$ ).

- Taxa de senescência de folhas: variação média no comprimento da porção senescente da folha, resultado do produto entre o comprimento da lâmina foliar senescente e a proporção de tecido senescente correspondente observada ao longo do período de avaliação ( $\mathrm{cm}$ perfilho ${ }^{-1}$ dia $^{-1}$ ).

- Crescimento: somatória do alongamento de hastes e expansão de folhas.

- Senescência: somatória da senescência de folhas e de hastes.

- Acúmulo líquido: balanço entre crescimento (fator positivo) e senescência (fator negativo), ambos multiplicados pela densidade populacional de perfilhos antes da realização da somatória indicada abaixo:

$$
\text { Acúmulo Líquido = Crescimento }- \text { Senescência }
$$

\subsubsection{Densidade populacional e massa de perfilhos individuais}

Para obtenção da densidade populacional de perfilhos foram realizadas contagens do número de perfilhos contidos no interior de três áreas retangulares de $1 \mathrm{~m}^{2}$ (1,47 m por 0,68 m) por unidade experimental (adaptado de Herling et al., $1998 \mathrm{~b}$ ) em cada uma das alturas pré-determinadas de avaliação. Quando essas áreas deixavam de ser representativas da unidade experimental eram escolhidos outros pontos de amostragem que representassem a condição média dos pastos por ocasião das avaliações.

A massa por perfilho foi obtido a partir de uma amostragem de 50 perfilhos colhidos aleatoriamente em cada unidade experimental. Após colheita, os perfilhos eram secos em estufa a $65^{\circ} \mathrm{C}$ por 48 horas e pesados. 


\subsubsection{Massa de forragem}

A massa de forragem foi determinada diretamente através de cortes nas condições de pré e pós-pastejo. As amostras foram obtidas através do corte da forragem contida no interior de três áreas retangulares de $1 \mathrm{~m}^{2}(1,47 \times 0,68 \mathrm{~m})$ por parcela, alocados em pontos cuja altura fosse semelhante à condição média do dossel forrageiro da unidade experimental (adaptado de Herling et al., 1998 a). Os cortes foram padronizados a $20 \mathrm{~cm}$ de altura do nível do solo a fim de não comprometer o estande do pasto, e foram realizados com ajuda de um aparador de cerca viva movido a gasolina (Figura 10).

Após o corte, as amostras eram sistematicamente subdivididas sendo as amostras e subamostras pesadas verdes. A subamostra era, então, separada em seus componentes (lâminas foliares, hastes com bainhas das folhas, material morto e invasoras). Cada componente era seco separadamente e, após 48 horas em estufa a $65^{\circ} \mathrm{C}$, era pesado. A partir dos valores de peso seco da subamostra e de seus componentes foram calculados o teor de matéria seca da forragem e as proporções de cada um dos componentes. $\mathrm{O}$ teor de matéria seca da subamostra, multiplicado pela massa verde da amostra, gerou o valor de massa de forragem contida em cada quadrado de amostragem, que foi então convertido para $\mathrm{kg} \mathrm{ha}^{-1}$. 


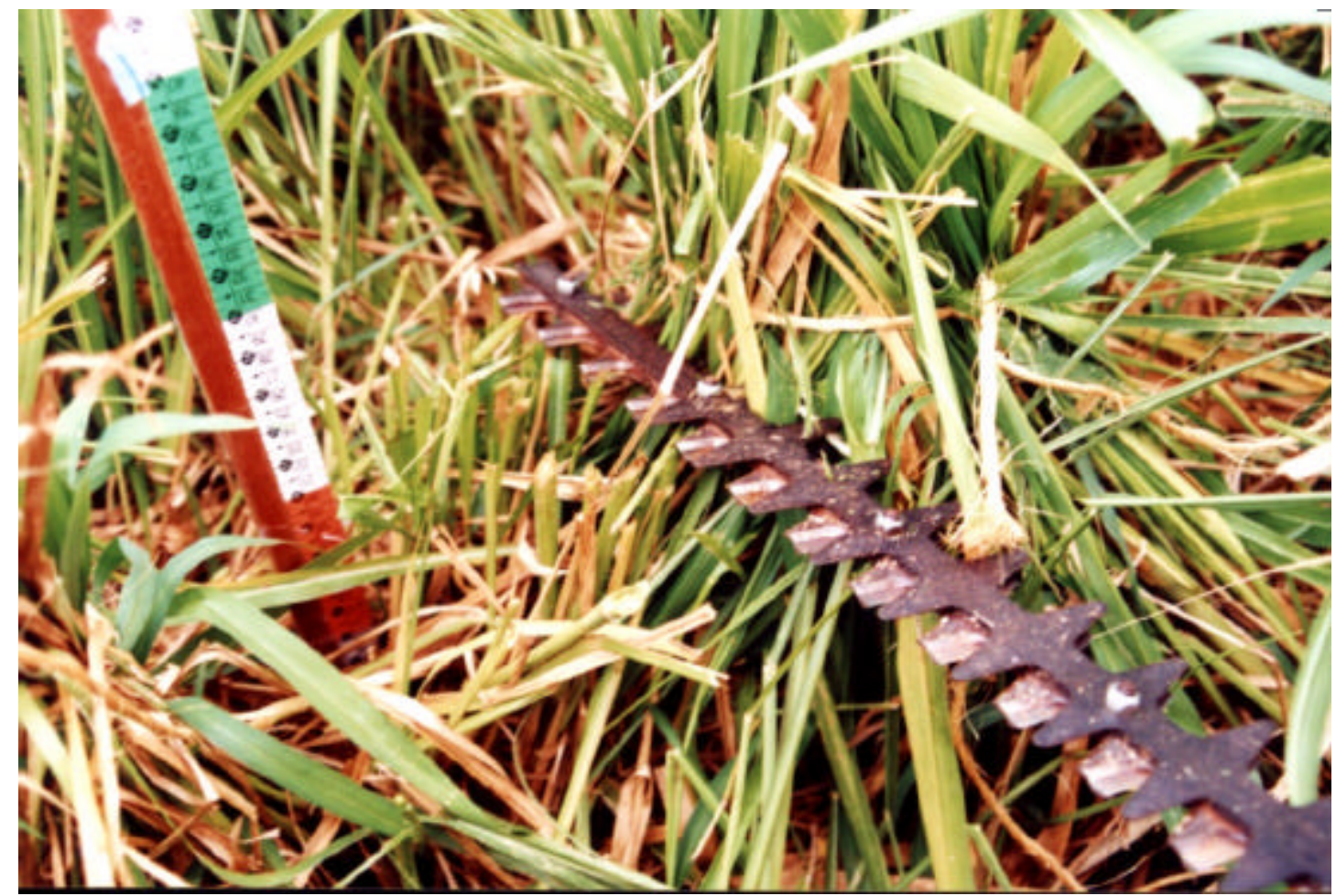

Figura 10- Corte da massa de forragem a $20 \mathrm{~cm}$ do solo com o aparador de cerca viva

\subsubsection{Taxa de acúmulo de forragem}

O acúmulo de forragem foi calculado por meio da diferença entre a massa de forragem no pós-pastejo anterior e no pré-pastejo atual para cada ciclo de pastejo. Esse valor foi dividido pelo número de dias do período de descanso correspondente, gerandose a taxa de acúmulo de forragem $\left(\mathrm{kg} \mathrm{ha}^{-1} \mathrm{dia}^{-1} \mathrm{de} \mathrm{MS}\right)$. Médias mensais foram então calculadas de forma ponderada a partir das taxas de cada ciclo de pastejo e do número de dias de cada mês correspondente a cada ciclo de pastejo.

\subsubsection{Perdas de forragem por pastejo}

As perdas por pastejo foram quantificadas a partir de três amostradores de $3 \mathrm{~m}^{2}$ $(1,5 \times 2,0 \mathrm{~m})$ previamente alocados por unidade experimental antes de cada pastejo. Por 
ocasião das avaliações de pré-pastejo, os amostradores eram alocados em áreas representativas da condição média do dossel forrageiro e, do seu interior, eram eliminados todos os resíduos de folhas, hastes ou material morto, deixando o solo desnudo. Esses locais eram visitados após o pastejo para a colheita dos resíduos referentes às perdas de forragem. Foi considerado como perda todo o material existente sobre a superfície do solo e todas as hastes e folhas danificadas que ainda estivessem presas às touceiras acima do resíduo determinado pelo tratamento. Após a colheita desse material, era retirada uma subamostra de cada amostra para determinação da composição morfológica das perdas. As amostras e subamostras eram então secas em estufa a $65^{\circ} \mathrm{C}$ por 48 horas e, posteriormente, pesadas. Nas situações onde a quantidade de forragem coletada era excessivamente grande, adotava-se o mesmo procedimento de subamostragem realizado na avaliação de massa de forragem (item 3.2.3.4).

\subsubsection{Estimativa da forragem removida}

A forragem removida foi estimada a partir da diferença entre os valores de massa de forragem obtidos imediatamente antes e após cada pastejo, sendo que a quantidade total de forragem removida ao longo do período experimental correspondeu à somatória dos valores referentes a cada ciclo de pastejo $\left(\mathrm{kg} \mathrm{ha}^{-1} \mathrm{dia}^{-1} \mathrm{de} \mathrm{MS}\right)$.

\subsubsection{Estimativa da forragem aproveitada (eficiência de pastejo ou utilização)}

A forragem aproveitada foi calculada através da diferença entre os valores de forragem removida e de perdas por pastejo. As perdas foram expressas como proporção da forragem removida (\%) e sua diferença em relação a 100 foram consideradas como sendo eficiência de pastejo ou de utilização. 


\subsection{Processamento dos dados e análise estatística}

A maior parte dos resultados foi agrupada de acordo com as épocas do ano (primavera, verão e outono/inverno). Essa medida foi necessária em função da variabilidade do intervalo entre desfolhações e datas dos pastejos de cada unidade experimental, provocada pela natureza dos tratamentos experimentais estudados (pastejos iniciados com 95 ou 100\% de IL do dossel forrageiro). Foram calculadas médias por pastejo em cada época para as seguintes variáveis: massa de forragem na condição de pré e pós-pastejo, densidade populacional e massa por perfilho, acúmulo líquido de lâminas foliares e hastes e perdas de forragem por ação do pastejo.

Como intervalo entre pastejos e datas dos pastejos de cada unidade experimental foram variáveis durante todo o experimento, o processo de rebrotação foi subdividido em fases com o objetivo de descrever o padrão de comportamento das variáveis estruturais do dossel e da dinâmica de acúmulo de forragem durante a rebrotação. Assim, para a análise das variáveis IAF, IL e ângulo da folhagem foram caracterizadas as seguintes fases: (1) condição de pós-pastejo (retirada dos animais das unidades experimentais), (2) primeiros $20 \mathrm{~cm}$ de incremento na altura do dossel forrageiro após o início da rebrotação, (3) últimos $20 \mathrm{~cm}$ de incremento na altura do dossel forrageiro após o início da rebrotação e (4) condição de pré-pastejo. Já para as variáveis densidade populacional de perfilhos, massa dos perfilhos e número de folhas (vivas, senescentes e em expansão) foram caracterizadas as seguintes fases: pós-pastejo, intermediária (metade do período de rebrotação) e pré-pastejo. Para as taxas de expansão e senscência de folhas, taxas de alongamento e senescência de hastes e encurtamento de bainhas foliares as fases foram caracterizadas por inicial (correspondente a taxa calculada no primeiro dia de rebrotação), intermediária (correspondente a taxa média calculada do primeiro dia de rebrotação até a metade do período de rebrotação) e final (correspondente a taxa média calculada da metade do período de rebrotação até o último dia antes do pastejo).

Os dados assim arranjados foram submetidos à análise de variância por meio do procedimento MIXED do pacote estatístico SAS (SAS Institute, 1989). A comparação de 
médias foi realizada por meio do LSMeans, adotando-se o nível de significância de $10 \%$. No caso dos resultados de produção total de forragem do experimento, a análise de variância foi realizada por meio do procedimento GLM do mesmo pacote estatístico. Relações funcionais entre IAF, altura e $\mathbf{L}$ do dossel forrageiro foram descritas por meio de recursos de regressões não lineares do programa computacional Sigmaplot. 


\section{RESULTADOS}

\subsection{Características do dossel forrageiro}

O dossel forrageiro do capim-Mombaça foi caracterizado por meio de variáveis estruturais do pasto: altura, massa de forragem, índice de área foliar, ângulo da folhagem, interceptação luminosa, número e massa de perfilhos. Em função da natureza dos tratamentos, variáveis como número de pastejos realizados durante o período experimental e intervalo médio entre pastejos foram mensurados como resposta e não controle.

\subsubsection{Número de pastejos e intervalo entre pastejos}

A altura de resíduo não afetou o número de pastejos realizados durante o ano $(\mathrm{P}>0,10)$. Por outro lado, houve efeito da interceptação luminosa $(\mathrm{P}=0,0314)$ sobre o número total de pastejos no ano (Tabela 3). Pastos manejados segundo o regime de $95 \%$ de IL apresentaram maior número de pastejos no ano (7,6 pastejos ano $\left.{ }^{-1}\right)$ que pastos manejados segundo o regime de $100 \%$ de IL (5,9 pastejos ano $\left.{ }^{-1}\right)$. O número de pastejos dentro de cada época do ano também foi variável. Houve efeito de época do ano $(\mathrm{P}=0,0012)$ e de interceptação luminosa $(\mathrm{P}=0,0012)$ quando o número de pastejos foi analisado dentro de cada época do ano. Na Tabela 4, observa-se que houve um maior número de pastejos durante o verão $\left(2,8\right.$ pastejos ano $\left.^{-1}\right)$ comparativamente à primavera (2,0 pastejos $\left.a^{-1}\right)$. Além disso, o número de pastejos em seis meses do ano, correspondente ao período de outono/inverno (2,0 pastejos ano $\left.{ }^{-1}\right)$, foi igual àqueles dos três meses da primavera. 
Tabela 3. Número total de pastejos realizados durante o ano em capim-Mombaça submetido a regimes de pastejo intermitente

\begin{tabular}{cccc}
\hline $\begin{array}{c}\text { Resíduo } \\
(\mathrm{cm})\end{array}$ & \multicolumn{3}{c}{ Interceptação luminosa (\%) } \\
\hline 30 & 7,0 & 100 & Média \\
\hline \multirow{3}{*}{50} & $(0,69)$ & 6,0 & 6,5 \\
& 8,3 & $5,69)$ & $(0,49)$ \\
Média & $(0,69)$ & $(0,69)$ & $(0,49)$ \\
& $7,6 \mathrm{~A}$ & $5,9 \mathrm{~B}$ & 6,8 \\
& $(0,49)$ & $(0,49)$ & \\
\hline
\end{tabular}

Números entre parênteses correspondem ao erro padrão da média.

Médias na mesma linha seguidas de mesma letra maiúscula não diferem entre si $(\mathrm{P}>0,10)$.

Tabela 4. Número de pastejos no capim-Mombaça para os tratamentos de 95 e $100 \%$ de interceptação luminosa durante as épocas do ano

\begin{tabular}{ccccc}
\hline $\begin{array}{c}\text { Interceptação } \\
\text { luminosa (\%) }\end{array}$ & Verão & $\begin{array}{r}\text { Epoca do ano } \\
\text { Outono/Inverno }\end{array}$ & Primavera & Média \\
\hline 95 & 3,1 & 2,3 & 2,6 & $2,7 \mathrm{a}$ \\
& $(0,29)$ & $(0,29)$ & $(0,29)$ & $(0,20)$ \\
100 & 2,5 & 1,8 & 1,4 & $1,9 \mathrm{~b}$ \\
& $(0,29)$ & $(0,29)$ & $(0,29)$ & $(0,20)$ \\
Média & $2,8 \mathrm{~A}$ & $2,0 \mathrm{~B}$ & $2,0 \mathrm{~B}$ & 2,3 \\
& $(0,14)$ & $(0,13)$ & $(0,17)$ & \\
\hline
\end{tabular}

Números entre parênteses correspondem ao erro padrão da média.

Médias na mesma coluna seguidas de mesma letra minúscula não diferem entre si $(\mathrm{P}>0,10)$.

Médias na mesma linha seguidas de mesma letra maiúscula não diferem entre si $(P>0,10)$.

Os intervalos médios entre pastejos registrados durante o período experimental estão apresentados na Figura 11. A interceptação luminosa foi a principal determinante do intervalo entre pastejos. Observa-se que os tratamentos de 95\% de IL apresentaram intervalos entre pastejos menores ( 22 a 25 dias) que os tratamentos de $100 \%$ de IL (31 a 40 dias) durante a primavera e verão. Já para outono/inverno, a altura do resíduo influenciou o intervalo entre pastejos. Os tratamentos com $30 \mathrm{~cm}$ de resíduo apresentaram intervalos entre pastejos menores (95 a 115 dias) que os de $50 \mathrm{~cm}$ (140 a 186 dias). Nota-se um grande intervalo entre pastejos para o tratamento 50/100 (186 dias), pois houve somente um pastejo no início do outono e outro apenas depois da entrada da primavera. Os intervalos entre pastejos afetaram fortemente a estrutura do 
dossel forrageiro e a intensidade de florescimento no final do verão e durante o outono e inverno (Figura 12 e 13).

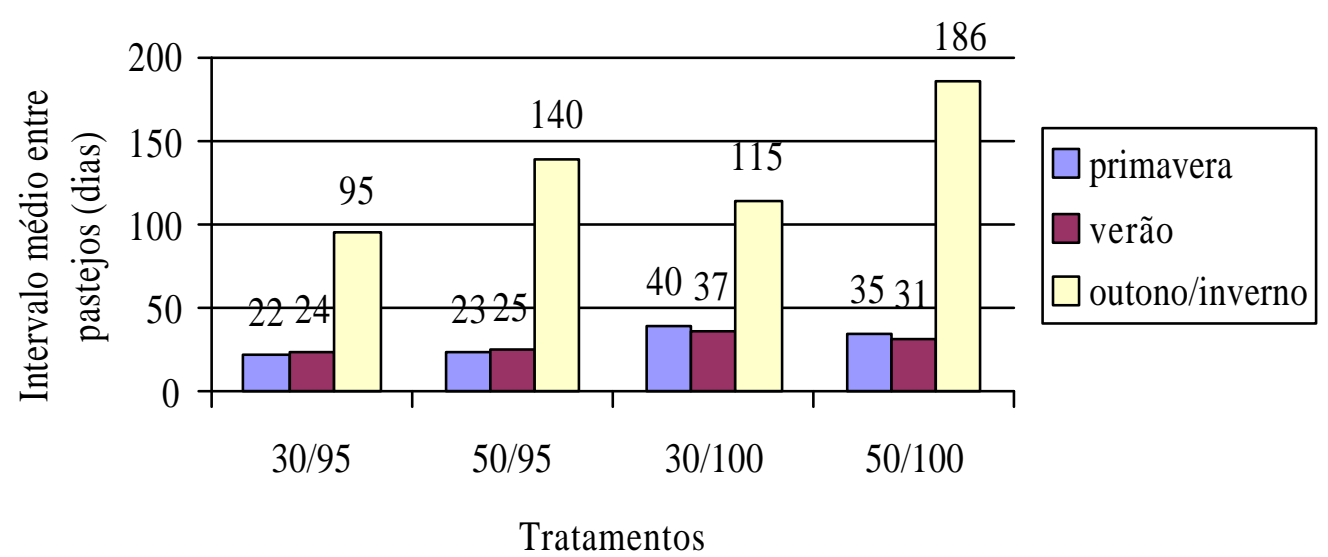

Figura 11- Intervalo médio entre pastejos (dias) para os tratamentos durante o período experimental

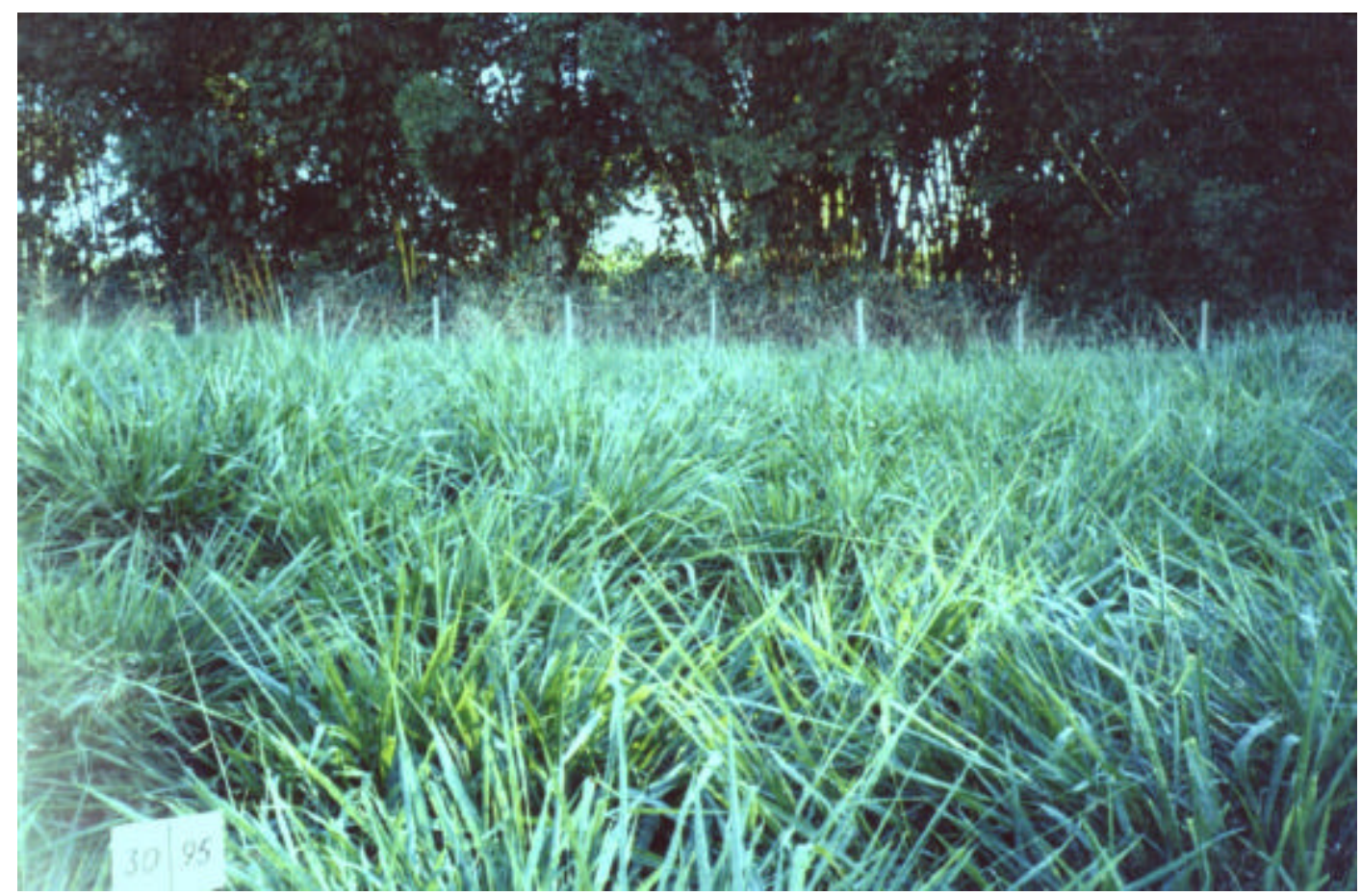

Figura 12- Estrutura do dossel do tratamento 30/95 no período de florescimento (maio) 


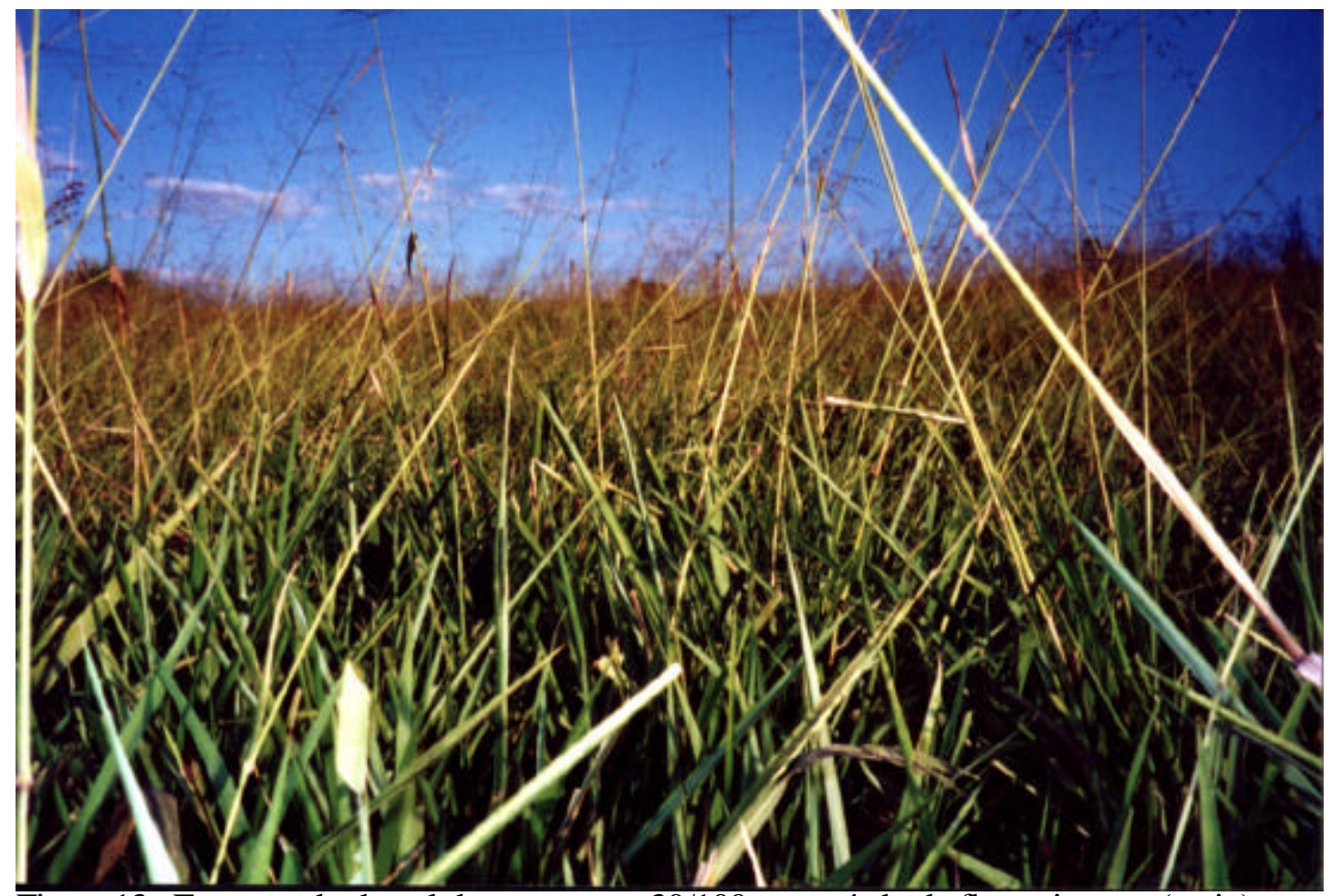

Figura 13- Estrutura do dossel do tratamento 30/100 no período de florescimento (maio)

\subsubsection{Altura do dossel}

Os valores efetivos de altura do resíduo pós-pastejo mensurados ao longo do experimento são apresentados na Tabela 5. Houve efeito da interação interceptação luminosa $\mathrm{x}$ resíduo $\mathrm{x}$ época do ano $(\mathrm{P}=0,1119)$ e efeito de interceptação luminosa $(\mathrm{P} \leq 0,0001)$, resíduo $(\mathrm{P} \leq 0,0001)$ e época do ano $(\mathrm{P} \leq 0,0001)$. A altura do resíduo foi mantida relativamente constante ao longo de todo o ano para o tratamento de resíduo 30/95 (33-35 cm). Para o resíduo de $30 \mathrm{~cm}$, quando a interceptação luminosa foi de $100 \%$, houve aumento da altura do resíduo $(33-50 \mathrm{~cm})$ durante o ano, particularmente no verão, outono e inverno. Comportamento semelhante pôde ser observado para o resíduo mantido a $50 \mathrm{~cm}$ e com pastejo iniciado em $100 \%$ de IL $(50-59 \mathrm{~cm})$, particularmente durante o inverno. De forma geral, a altura dos resíduos foi crescente para os tratamentos de $100 \%$ IL ao longo das estações do ano, com os maiores valores 
registrados no período de inverno. Para os tratamentos de 95\% de IL, os valores foram relativamente constantes durante todo o ano

Tabela 5. Altura do dossel forrageiro de capim-Mombaça na condição de pós-pastejo (cm) durante as épocas do ano

\begin{tabular}{|c|c|c|c|}
\hline \multicolumn{4}{|c|}{ Interceptação luminosa (\%) } \\
\hline Resíduo (cm) & 95 & 100 & Média \\
\hline \multicolumn{4}{|c|}{ Primavera } \\
\hline 30 & $\begin{array}{c}33,4 \mathrm{Ab} \\
(1,52)\end{array}$ & $\begin{array}{c}33,8 \mathrm{Ab} \\
(1,52)\end{array}$ & $\begin{array}{c}33,6 \mathrm{~b} \\
(1,08)\end{array}$ \\
\hline 50 & $\begin{array}{c}48,4 \mathrm{Aa} \\
(1,52)\end{array}$ & $\begin{array}{c}50,6 \mathrm{Aa} \\
(1,52)\end{array}$ & $\begin{array}{r}49,5 \mathrm{a} \\
(1,08)\end{array}$ \\
\hline Média & $\begin{array}{c}40,9 \mathrm{~A} \\
(1,08)\end{array}$ & $\begin{array}{l}42,2 \mathrm{~A} \\
(1,08)\end{array}$ & $\begin{array}{c}41,6 C^{\prime} \\
(0,76)\end{array}$ \\
\hline \multicolumn{4}{|c|}{ Verão } \\
\hline 30 & $\begin{array}{c}35,2 \mathrm{Bb} \\
(1,52)\end{array}$ & $\begin{array}{c}42,2 \mathrm{Ab} \\
(1,52)\end{array}$ & $\begin{array}{c}38,7 \mathrm{~b} \\
(1,08)\end{array}$ \\
\hline 50 & $\begin{array}{c}50,1 \mathrm{Aa} \\
(1,52)\end{array}$ & $\begin{array}{c}53,5 \mathrm{Aa} \\
(1,52)\end{array}$ & $\begin{array}{r}51,8 \mathrm{a} \\
(1,08)\end{array}$ \\
\hline Média & $\begin{array}{l}42,7 \mathrm{~B} \\
(1,08)\end{array}$ & $\begin{array}{l}47,9 \mathrm{~A} \\
(1,08)\end{array}$ & $\begin{array}{c}45,3 \text { B } \\
(0,76)\end{array}$ \\
\hline \multicolumn{4}{|c|}{ Outono } \\
\hline 30 & $\begin{array}{c}33,2 \mathrm{Bb} \\
(1,52)\end{array}$ & $\begin{array}{c}41,3 \mathrm{Ab} \\
(1,52)\end{array}$ & $\begin{array}{l}37,2 \mathrm{~b} \\
(1,08)\end{array}$ \\
\hline 50 & $\begin{array}{c}51,1 \mathrm{Aa} \\
(1,52)\end{array}$ & $\begin{array}{c}54,7 \mathrm{Aa} \\
(1,52)\end{array}$ & $\begin{array}{l}52,9 \mathrm{a} \\
(1,08)\end{array}$ \\
\hline Média & $\begin{array}{l}42,1 \mathrm{~B} \\
(1,08)\end{array}$ & $\begin{array}{r}48,0 \mathrm{~A} \\
(1,08)\end{array}$ & $\begin{array}{c}45,1 \mathrm{~B} \\
(0,76)\end{array}$ \\
\hline \multicolumn{4}{|c|}{ Inverno } \\
\hline 30 & $\begin{array}{c}33,0 \mathrm{Bb} \\
(1,52)\end{array}$ & $\begin{array}{c}50,7 \mathrm{Ab} \\
(1,52)\end{array}$ & $\begin{array}{r}41,9 \mathrm{~b} \\
(1,08)\end{array}$ \\
\hline 50 & $\begin{array}{c}50,4 \mathrm{Ba} \\
(1,52)\end{array}$ & $\begin{array}{c}59,0 \mathrm{Aa} \\
(1,52)\end{array}$ & $\begin{array}{l}54,7 \mathrm{a} \\
(1,08)\end{array}$ \\
\hline Média & $\begin{array}{c}41,7 \mathrm{~B} \\
(1,08)\end{array}$ & $\begin{array}{c}54,9 \mathrm{~A} \\
(1,08)\end{array}$ & $\begin{array}{c}48,3 A^{\prime} \\
(0,76)\end{array}$ \\
\hline
\end{tabular}

Números entre parênteses correspondem ao erro padrão da média.

Médias na mesma coluna seguidas de mesma letra mi núscula não diferem entre si $(\mathrm{P}>0,10)$.

Médias na mesma linha seguidas de mesma letra maiúscula não diferem entre si $(\mathrm{P}>0,10)$.

Médias de épocas do ano seguidas de letras maiúsculas acrescidas de ( ') não diferem entre si (P>0,10).

A altura do dossel forrageiro no momento do pastejo registrada durante o experimento mostrou-se relativamente constante para todos os tratamentos. Houve efeito 
de resíduo $(\mathrm{P}=0,0504)$, interceptação luminosa $(\mathrm{P} \leq 0,0001)$ e época do ano $(\mathrm{P}=0,0166)$. Os tratamentos com resíduo de $30 \mathrm{~cm}$ resultaram numa menor altura de dossel $(99,7 \mathrm{~cm})$ por ocasião do início do pastejo em todas as épocas do ano (Tabela 6). Contudo, a diferença entre $30(99,7 \mathrm{~cm})$ e $50 \mathrm{~cm}(104,6 \mathrm{~cm})$ foi pequena. Na primavera e no verão, as alturas foram menores do que no outono/inverno

Tabela 6. Altura do dossel forrageiro na condição de pré-pastejo $(\mathrm{cm})$ para os tratamentos de 30 e $50 \mathrm{~cm}$ de resíduo durante as épocas do ano

\begin{tabular}{cccc}
\hline \multirow{2}{*}{ Época do ano } & 30 & Resíduo $(\mathrm{cm})$ & Média \\
\hline Primavera & 97,1 & 90,5 & $98,3 \mathrm{~b}$ \\
& $(3,05)$ & $(3,05)$ & $(2,16)$ \\
Verão & 93,3 & 104,0 & $98,7 \mathrm{~b}$ \\
& $(3,05)$ & $(3,05)$ & $(2,16)$ \\
Outono & 104,1 & 105,1 & $104,6 \mathrm{a}$ \\
& $(3,05)$ & $(3,05)$ & $(2,16)$ \\
Inverno & 104,2 & 109,8 & $107,0 \mathrm{a}$ \\
& $(3,31)$ & $(3,05)$ & $(2,16)$ \\
Média & $99,7 \mathrm{~B}$ & $104,6 \mathrm{~A}$ & 102,2 \\
& $(1,56)$ & $(1,53)$ & \\
\hline
\end{tabular}

Números entre parênteses correspondem ao erro padrão da média.

Médias na mesma coluna seguidas de mesma letra minúscula não diferem entre si $(\mathrm{P}>0,10)$.

Médias na mesma linha seguidas de mesma letra maiúscula não diferem entre si $(\mathrm{P}>0,10)$.

O principal agente determinante da altura do dossel forrageiro por ocasião da entrada dos animais para o pastejo foi a interceptação luminosa. Na Tabela 7, pode-se observar que a diferença em altura do dossel entre $95(88,7 \mathrm{~cm})$ e $100 \%$ de IL $(115,5$ $\mathrm{cm}$ ) foi superior a $26 \mathrm{~cm}$ na média das épocas do ano. Durante o ano a diferença oscilou, porém os tratamentos de $95 \%$ de IL apresentaram uma altura de dossel consistentemente inferior àquelas dos tratamentos de $100 \%$ de IL. Além disso, os valores de altura do dossel forrageiro para os tratamentos de 95 e $100 \%$ de IL mantiveram-se relativamente constantes ao longo do ano (em torno de $90 \mathrm{~cm}$ para $95 \%$ de IL e de $115 \mathrm{~cm}$ para $100 \%$ de IL). 
Tabela 7. Altura do dossel forrageiro $(\mathrm{cm})$ de capim-Mombaça na condição de prépastejo para os tratamentos de 95 e 100\% de interceptação luminosa durante as épocas do ano

\begin{tabular}{cccc}
\hline \multirow{2}{*}{ Épocas do ano } & \multicolumn{2}{c}{ Interceptação luminosa $(\%)$} & Média \\
\hline Primavera & 95 & 100 & $98,3 \mathrm{~b}$ \\
& 86,7 & 109,8 & $(2,16)$ \\
Verão & $(3,05)$ & $(3,05)$ & $98,7 \mathrm{~b}$ \\
& 86,9 & 110,4 & $(2,16)$ \\
Outono & $(3,05)$ & $(3,05)$ & $104,6 \mathrm{a}$ \\
& 92,2 & 116,9 & $(2,16)$ \\
Inverno & $(3,05)$ & $(3,05)$ & $107,0 \mathrm{a}$ \\
& 88,9 & 125,0 & $(2,16)$ \\
Média & $(3,05)$ & $(3,31)$ & 102,2 \\
& $88,7 \mathrm{~B}$ & $115,5 \mathrm{~A}$ & \\
\hline
\end{tabular}

Números entre parênteses correspondem ao erro padrão da média.

Médias na mesma coluna seguidas de mesma letra minúscula não diferem entre si $(\mathrm{P}>0,10)$.

Médias na mesma linha seguidas de mesma letra maiúscula não diferem entre si $(\mathrm{P}>0,10)$.

\subsubsection{Massa de forragem e composição morfológica}

O aumento em altura do dossel forrageiro em pós-pastejo (Tabela 5) esteve associado a um aumento na massa de forragem pós-pastejo (Tabela 8). Houve efeito de interceptação luminosa $(\mathrm{P}<0,0001)$ e resíduo $(\mathrm{P}<0,0001)$, além da interação resíduo $\mathrm{x}$ interceptação luminosa $\mathrm{x}$ época do ano $(\mathrm{P}=0,0813)$. O tratamento 30/95 foi o que resultou na menor massa de forragem pós-pastejo (1.400 a $\left.2.000 \mathrm{~kg} \mathrm{ha}^{-1} \mathrm{de} \mathrm{MS}\right)$. Os maiores valores de massa de forragem ocorreram consistentemente na condição de $100 \%$ de IL. 
Tabela 8. Massa de forragem por pastejo de capim-Mombaça na condição de pós-pastejo ( $\mathrm{kg} \mathrm{ha}^{-1}$ de MS) durante as épocas do ano

\begin{tabular}{|c|c|c|c|}
\hline \multicolumn{4}{|c|}{ Interceptação Luminosa (\%) } \\
\hline Resíduo (cm) & 95 & 100 & Média \\
\hline \multicolumn{4}{|c|}{ Verão } \\
\hline 30 & $\begin{array}{c}1.470 \mathrm{Bb} \\
(164)\end{array}$ & $\begin{array}{c}3.990 \mathrm{Ab} \\
(164)\end{array}$ & $\begin{array}{c}2.730 \mathrm{~b} \\
(116)\end{array}$ \\
\hline 50 & $\begin{array}{l}3.310 \mathrm{Ba} \\
(164)\end{array}$ & $\begin{array}{c}4.470 \mathrm{Aa} \\
(164)\end{array}$ & $\begin{array}{c}3.890 \mathrm{a} \\
(116)\end{array}$ \\
\hline Média & $\begin{array}{c}2.390 \mathrm{~B} \\
(116)\end{array}$ & $\begin{array}{c}4.230 \mathrm{~A} \\
(116)\end{array}$ & $\begin{array}{c}3.310 \\
(82)\end{array}$ \\
\hline \multicolumn{4}{|c|}{ Outono/Inverno } \\
\hline 30 & $\begin{array}{c}2.010 \mathrm{Bb} \\
(342)\end{array}$ & $\begin{array}{c}3.740 \mathrm{Ab} \\
(342)\end{array}$ & $\begin{array}{c}2.870 \mathrm{~b} \\
(242)\end{array}$ \\
\hline 50 & $\begin{array}{c}3.030 \mathrm{Ba} \\
(342)\end{array}$ & $\begin{array}{c}5.390 \mathrm{Aa} \\
(342)\end{array}$ & $\begin{array}{c}4.210 \mathrm{a} \\
(242)\end{array}$ \\
\hline Média & $\begin{array}{c}2.520 \mathrm{~B} \\
(242)\end{array}$ & $\begin{array}{c}4.570 \mathrm{~A} \\
(242)\end{array}$ & $\begin{array}{l}3.540 \\
(171)\end{array}$ \\
\hline \multicolumn{4}{|c|}{ Primavera } \\
\hline 30 & $\begin{array}{c}1.840 \mathrm{Bb} \\
(205)\end{array}$ & $\begin{array}{c}4.270 \mathrm{Ab} \\
(205)\end{array}$ & $\begin{array}{c}3.050 \mathrm{~b} \\
(145)\end{array}$ \\
\hline 50 & $\begin{array}{c}2.930 \mathrm{Ba} \\
(205)\end{array}$ & $\begin{array}{c}4.920 \mathrm{Aa} \\
(205)\end{array}$ & $\begin{array}{c}3.920 \mathrm{a} \\
(145)\end{array}$ \\
\hline Média & $\begin{array}{c}2.380 \mathrm{~B} \\
(145)\end{array}$ & $\begin{array}{c}4.590 \mathrm{~A} \\
(145)\end{array}$ & $\begin{array}{l}3.490 \\
(102)\end{array}$ \\
\hline
\end{tabular}

Números entre parênteses correspondem ao erro padrão da média.

Médias na mesma coluna seguidas de mesma letra minúscula não diferem entre si $(P>0,10)$.

Médias na mesma linha seguidas de mesma letra maiúscula não diferem entre si $(P>0,10)$.

A massa de forragem na condição de pós-pastejo apresentou diferenças nas proporções de seus componentes. Houve interação resíduo $\mathrm{x}$ interceptação luminosa $\mathrm{x}$ época do ano $(\mathrm{P}=0,0033)$ e efeito de interceptação luminosa $(\mathrm{P}<0,0001)$ e época do ano $(\mathrm{P}=0,0014)$ para a proporção de lâminas foliares presentes na massa de forragem residual. Os tratamentos com 95\% de IL apresentaram maiores proporções de lâminas foliares (41 a 49\%) no resíduo que os tratamentos com 100\% de IL (32 a 36\%) em todas as épocas do ano (Tabela 9). Houve uma queda na proporção de lâminas foliares no período de outono/inverno. 
Tabela 9. Proporção de lâminas foliares (\%) na massa de forragem do dossel de capimMombaça na condição de pós-pastejo durante as épocas do ano

\begin{tabular}{|c|c|c|c|}
\hline \multirow[b]{2}{*}{ Resíduo (cm) } & \multicolumn{3}{|c|}{ Interceptação luminosa (\%) } \\
\hline & 95 & 100 & Média \\
\hline \multicolumn{4}{|c|}{ Verão } \\
\hline 30 & $\begin{array}{c}50,5 \mathrm{Aa} \\
(2,53)\end{array}$ & $\begin{array}{c}31,1 \mathrm{Ba} \\
(2,53)\end{array}$ & $\begin{array}{c}40,8 \\
(1,79)\end{array}$ \\
\hline 50 & $\begin{array}{c}42,0 \mathrm{Ab} \\
(2,53)\end{array}$ & $\begin{array}{c}35,4 \mathrm{Ba} \\
(2,53)\end{array}$ & $\begin{array}{c}38,7 \\
(1,79)\end{array}$ \\
\hline Média & $\begin{array}{c}46,2 \mathrm{~A} \\
(1,79)\end{array}$ & $\begin{array}{l}33,3 \mathrm{~B} \\
(1,79)\end{array}$ & $\begin{array}{r}39,8 \mathrm{~A}^{\prime} \\
(1,27)\end{array}$ \\
\hline \multicolumn{4}{|c|}{ Outono/Inverno } \\
\hline 30 & $\begin{array}{c}39,5 \mathrm{Aa} \\
(2,53)\end{array}$ & $\begin{array}{c}34,2 \mathrm{Ba} \\
(2,53)\end{array}$ & $\begin{array}{c}36,8 \\
(1,79)\end{array}$ \\
\hline 50 & $\begin{array}{c}42,7 \mathrm{Aa} \\
(2,53)\end{array}$ & $\begin{array}{c}29,2 \mathrm{Ba} \\
(2,53)\end{array}$ & $\begin{array}{c}35,9 \\
(1,79)\end{array}$ \\
\hline Média & $\begin{array}{c}41,1 \mathrm{~A} \\
(1,79)\end{array}$ & $\begin{array}{l}31,8 \mathrm{~B} \\
(1,79)\end{array}$ & $\begin{array}{r}36,4 \mathrm{~B}^{\prime} \\
(1,27)\end{array}$ \\
\hline \multicolumn{4}{|c|}{ Primavera } \\
\hline 30 & $\begin{array}{c}48,9 \mathrm{Aa} \\
(2,53)\end{array}$ & $\begin{array}{c}37,2 \mathrm{Ba} \\
(2,53)\end{array}$ & $\begin{array}{c}43,0 \\
(1,79)\end{array}$ \\
\hline 50 & $\begin{array}{c}49,0 \mathrm{Aa} \\
(2,53)\end{array}$ & $\begin{array}{c}34,3 \mathrm{Ba} \\
(2,53)\end{array}$ & $\begin{array}{c}41,7 \\
(1,79)\end{array}$ \\
\hline Média & $\begin{array}{c}48,9 \mathrm{~A} \\
(1,79)\end{array}$ & $\begin{array}{c}35,8 \mathrm{~B} \\
(1,79)\end{array}$ & $\begin{array}{r}42,3 \mathrm{~A}^{\prime} \\
(1,27)\end{array}$ \\
\hline
\end{tabular}

Números entre parênteses correspondem ao erro padrão da média.

Médias na mesma coluna seguidas de mesma letra minúscula não diferem entre si $(\mathrm{P}>0,10)$.

Médias na mesma linha seguidas de mesma letra maiúscula não diferem entre si $(\mathrm{P}>0,10)$.

Médias de épocas do ano seguidas de letras maiúsculas acrescidas de (') não diferem entre si (P>0,10).

Em relação a hastes, os tratamentos com resíduo de $30 \mathrm{~cm}$ apresentaram menores proporções de hastes $(25,8 \%)$ que os tratamentos de $50 \mathrm{~cm}(30,2 \%)$ (Tabela 10). Houve efeito de resíduo $(\mathrm{P}=0,0167)$, interceptação luminosa $(\mathrm{P}<0,0001)$ e época do ano $(\mathrm{P}<0,0001)$ para a proporção de hastes na massa de forragem pós-pastejo. Os tratamentos com $100 \%$ de IL propiciaram maior proporção de hastes na massa de forragem pós-pastejo $(32,8 \%)$ que os tratame ntos com 95\% IL $(23,1 \%)$ (Tabela 10). 
Tabela 10. Proporção de hastes (\%) na massa de forragem de capim-Mombaça na condição de pós-pastejo para os tratamentos de 30 e $50 \mathrm{~cm}$ de resíduo

\begin{tabular}{cccc}
\hline Resíduo $(\mathrm{cm})$ & 95 & 100 & Média \\
\hline 30 & 19,9 & 31,6 & $25,8 \mathrm{~b}$ \\
& $(3,00)$ & $(3,00)$ & $(1,48)$ \\
50 & 26,2 & 34,0 & $30,2 \mathrm{a}$ \\
& $(3,00)$ & $(3,00)$ & $(1,48)$ \\
Média & $23,1 \mathrm{~B}$ & $32,8 \mathrm{~A}$ & 28,0 \\
& $(1,48)$ & $(1,48)$ & \\
\hline
\end{tabular}

Números entre parênteses correspondem ao erro padrão da média.

Médias na mesma coluna seguidas de mesma letra minúscula não diferem entre si $(\mathrm{P}>0,10)$.

Médias na mesma linha seguidas de mesma letra maiúscula não diferem entre si $(\mathrm{P}>0,10)$.

A primavera foi a época do ano em que ocorreu a menor proporção de hastes (21,5\%). No verão, houve um maior desenvolvimento e acúmulo de hastes (vegetativas) (33,9\%), especialmente no tratamento de pastejos mais lenientes (50/100). No outono/inverno, houve uma redução na proporção de hastes vegetativas $(28,5 \%)$ e aumento da proporção de hastes reprodutivas $(1,2 \%)$ (aquelas que apresentaram inflorescência visível). Nas outras estações do ano não foi constatada a presença de hastes reprodutivas.

Para a proporção de material morto presente na massa de forragem pós-pastejo, houve efeito de época do ano $(\mathrm{P}<0,0001)$ e resíduo $(\mathrm{P}=0,0405)$. Na Tabela 11 , observase que os tratamentos com resíduo de $30 \mathrm{~cm}$ apresentaram maior proporção de material morto $(34,8 \%)$, particularmente nas situações de pastejos realizados com $100 \%$ de IL. O verão foi a época do ano em foi registrada a menor proporção de material morto $(25,6 \%)$ (Tabela 11). Já no outono/inverno, houve aumento considerável da proporção de material morto $(35,1 \%)$. Como conseqüência, na primavera foi encontrada a maior proporção de material morto de todo o ano (37\%). 
Tabela 11. Proporção de material morto (\%) na massa de forragem na condição de póspastejo de capim-Mombaça para os tratamentos de 30 e $50 \mathrm{~cm}$ de resíduo durante as épocas do ano

\begin{tabular}{ccccc}
\hline Resíduo $(\mathrm{cm})$ & Verão & Outono/Inverno & Primavera & Média \\
\hline 30 & 27,1 & 36,6 & 40,5 & $34,8 \mathrm{a}$ \\
& $(2,64)$ & $(2,64)$ & $(2,64)$ & $(1,76)$ \\
50 & 24,1 & 33,6 & 33,5 & $30,4 \mathrm{~b}$ \\
& $(2,64)$ & $(2,64)$ & $(2,64)$ & $(1,76)$ \\
Média & $25,6 \mathrm{~B}$ & $35,1 \mathrm{~A}$ & $37,0 \mathrm{~A}$ & 32,6 \\
& $(2,15)$ & $(2,15)$ & $(2,15)$ &
\end{tabular}

Números entre parênteses correspondem ao erro padrão da média.

Médias na mesma coluna seguidas de mesma letra minúscula não diferem entre si $(\mathrm{P}>0,10)$.

Médias na mesma linha seguidas de mesma letra maiúscula não diferem entre si $(\mathrm{P}>0,10)$.

Os valores de massa de forragem na condição de pré-pastejo apresentaram maior homogeneidade que os valores obtidos de massa de forragem na condição de póspastejo. Foram obtidos efeitos de resíduo $(\mathrm{P}=0,0016)$, interceptação luminosa $(\mathrm{P}<0,0001)$ e época do ano $(\mathrm{P}=0,0026)$, além das interações resíduo x interceptação luminosa $\mathrm{x}$ época do ano $(\mathrm{P}=0,0352)$, resíduo $\mathrm{x}$ época do ano $(\mathrm{P}=0,0002)$ e interceptação luminosa $\mathrm{x}$ época do ano $(\mathrm{P}=0,0003)$. Os tratamentos de $95 \%$ de $\mathrm{IL}$ apresentaram valores de massa de forragem menores (4.300 a $4.800 \mathrm{~kg} \mathrm{ha}^{-1}$ de MS) que os tratamentos de $100 \%$ de IL (7.300 a $8.900 \mathrm{~kg} \mathrm{ha}^{-1}$ de MS) (Tabela 12). Os valores médios de massa de forragem durante o ano foram muito semelhantes, havendo somente uma elevação ao redor de $600 \mathrm{~kg} \mathrm{ha}^{-1}$ de MS durante a primavera. Os tratamentos com $50 \mathrm{~cm}$ de resíduo proporcionaram maiores valores de massa de forragem em pré-pastejo do que os tratamentos de $30 \mathrm{~cm}$, sendo que as diferenças estiveram em torno de 500 a $800 \mathrm{~kg} \mathrm{ha}^{-1}$ de MS no verão e de $2.300 \mathrm{~kg} \mathrm{ha}^{-1}$ de MS durante o outono/inverno. 
Tabela 12. Massa de forragem por pastejo ( $\mathrm{kg} \mathrm{ha}^{-1}$ de MS) na condição de pré-pastejo de capim-Mombaça durante as épocas do ano

\begin{tabular}{|c|c|c|c|}
\hline \multirow[b]{2}{*}{ Resíduo (cm) } & \multicolumn{3}{|c|}{ Interceptação luminosa (\%) } \\
\hline & 95 & 100 & Média \\
\hline \multicolumn{4}{|c|}{ Verão } \\
\hline 30 & $\begin{array}{c}4.800 \mathrm{Bb} \\
(443)\end{array}$ & $\begin{array}{c}\text { 7.220 Aa } \\
(443)\end{array}$ & $\begin{array}{c}6.010 \mathrm{~b}(\mathrm{~B} ") \\
(313)\end{array}$ \\
\hline 50 & $\begin{array}{c}6.190 \mathrm{Ba} \\
(443)\end{array}$ & $\begin{array}{c}7.460 \mathrm{Aa} \\
(443)\end{array}$ & $\begin{array}{c}6.820 \mathrm{a}(\mathrm{B} ") \\
(313)\end{array}$ \\
\hline Média & $\begin{array}{c}5.500 \mathrm{~B}\left(\mathrm{a}^{\prime}\right) \\
(313)\end{array}$ & $\begin{array}{c}7.340 \mathrm{~A}\left(\mathrm{~b}^{\prime}\right) \\
(313)\end{array}$ & $\begin{array}{c}6.420 \mathrm{~B}^{\prime} \\
(221)\end{array}$ \\
\hline \multicolumn{4}{|c|}{ Outono/Inverno } \\
\hline 30 & $\begin{array}{c}4.300 \mathrm{Bb} \\
(443)\end{array}$ & $\begin{array}{c}6.070 \mathrm{Ab} \\
(443)\end{array}$ & $\begin{array}{c}5.190 \mathrm{~b}\left(\mathrm{C}^{\prime \prime}\right) \\
(313)\end{array}$ \\
\hline 50 & $\begin{array}{c}6.320 \mathrm{Ba} \\
\quad(443)\end{array}$ & $\begin{array}{l}8.630 \mathrm{Aa} \\
(443)\end{array}$ & $\begin{array}{c}7.480 \mathrm{a}(\mathrm{A} ") \\
(313)\end{array}$ \\
\hline Média & $\begin{array}{c}5.310 \mathrm{~B}\left(\mathrm{a}^{\prime}\right) \\
(313)\end{array}$ & $\begin{array}{c}7.350 \mathrm{~A}\left(\mathrm{~b}^{\prime}\right) \\
(313)\end{array}$ & $\begin{array}{c}6.330 \mathrm{~B}^{\prime} \\
(221)\end{array}$ \\
\hline \multicolumn{4}{|c|}{ Primavera } \\
\hline 30 & $\begin{array}{c}4.640 \mathrm{Bb} \\
(443)\end{array}$ & $\begin{array}{l}8.920 \mathrm{Aa} \\
(443)\end{array}$ & $\begin{array}{c}6.780 \mathrm{a}(\mathrm{A} ") \\
(313)\end{array}$ \\
\hline 50 & $\begin{array}{l}5.870 \mathrm{Ba} \\
(443)\end{array}$ & $\begin{array}{l}8.690 \mathrm{Aa} \\
(443)\end{array}$ & $\begin{array}{c}7.280 \mathrm{a}(\mathrm{A} ") \\
(313)\end{array}$ \\
\hline Média & $\begin{array}{c}5.260 \mathrm{~B}\left(\mathrm{a}^{\prime}\right) \\
(313)\end{array}$ & $\begin{array}{c}8.800 \mathrm{~A}\left(\mathrm{a}^{\prime}\right) \\
(313)\end{array}$ & $\begin{array}{c}7.030 \mathrm{~A}^{\prime} \\
(221)\end{array}$ \\
\hline
\end{tabular}

Números entre parênteses correspondem ao erro padrão da média.

Médias na mesma coluna seguidas de mesma letra minúscula não diferem entre si $(\mathrm{P}>0,10)$.

Médias na mesma linha seguidas de mesma letra maiúscula não diferem entre si $(\mathrm{P}>0,10)$.

Médias de épocas do ano seguidas de letras maiúsculas acrescidas de ( ') não diferem entre si (P>0,10).

Médias de resíduo na mesma coluna seguidas de letras maiúsculas acrescidas de ( ") não diferem entre si $(\mathrm{P}>0,10)$.

Médias de interceptação luminosa na mesma coluna seguidas de letras minúsculas acrescidas de ( ') não diferem entre si $(\mathrm{P}>0,10)$.

A composição da massa de forragem em pré-pastejo variou entre os tratamentos e ao longo do ano. Houve efeito da interação interceptação luminosa x resíduo sobre a proporção de folhas $(\mathrm{P}=0,1057)$, hastes $(\mathrm{P}=0,1096)$ e material morto $(\mathrm{P}=0,0812)$ e efeito de época do ano para proporção de folhas $(\mathrm{P}=0,0039)$, hastes $(\mathrm{P}=0,0382)$ e material morto $(\mathrm{P}=0,0091)$. A interação época do ano x resíduo $(\mathrm{P}=0,0788)$ influenciou apenas a proporção de folhas na massa de forragem em pré-pastejo. 
O tratamento 30/95 apresentou a maior proporção de lâminas foliares $(70,9 \%)$ e as menores proporções de hastes $(14,7 \%)$ e de material morto $(13,6 \%)$ (Tabela 13). O tratamento 30/100 destacou-se pela alta proporção de hastes (26,4\%). Os demais tratamentos não exerceram influência sobre a composição morfológica média da massa de forragem em pré-pastejo, a qual girou em torno de $60 \%$ de folhas, $20 \%$ d hastes e $20 \%$ de material morto. A proporção de lâminas foliares foi maior na estação das águas (primavera e verão) (Tabela 14). A proporção de hastes foi alta no verão $(28,1 \%)$ tendo sido reduzida durante o outono/inverno $(18,4 \%)$ e primavera $(15 \%)$.

Tabela 13. Composição morfológica média (\%) da massa de forragem em pré-pastejo para os tratamentos experimentais

\begin{tabular}{|c|c|c|c|}
\hline \multirow[b]{2}{*}{ Resíduo (cm) } & \multicolumn{3}{|c|}{ Interceptação luminosa (\%) } \\
\hline & 95 & 100 & Média \\
\hline \multicolumn{4}{|c|}{ \% Lâminas foliares } \\
\hline 30 & $\begin{array}{c}70,9 \mathrm{Aa} \\
(3,10)\end{array}$ & $\begin{array}{c}60,3 \mathrm{Ba} \\
(3,10)\end{array}$ & $\begin{array}{l}65,6 \mathrm{a} \\
(2,20)\end{array}$ \\
\hline 50 & $\begin{array}{c}57,7 \mathrm{Ab} \\
(3,10)\end{array}$ & $\begin{array}{c}57,5 \mathrm{Aa} \\
(3,10)\end{array}$ & $\begin{array}{l}57,6 \mathrm{~b} \\
(2,20)\end{array}$ \\
\hline Média & $\begin{array}{c}64,3 \mathrm{~A} \\
(2,20)\end{array}$ & $\begin{array}{l}58,9 \mathrm{~B} \\
(2,20)\end{array}$ & 61,6 \\
\hline \multicolumn{4}{|c|}{$\%$ Hastes } \\
\hline 30 & $\begin{array}{c}14,7 \mathrm{Ba} \\
(2,40)\end{array}$ & $\begin{array}{c}26,4 \mathrm{Aa} \\
(2,40)\end{array}$ & $\begin{array}{c}20,6 \\
(1,70)\end{array}$ \\
\hline 50 & $\begin{array}{c}18,9 \mathrm{Aa} \\
(2,40)\end{array}$ & $\begin{array}{c}22,1 \mathrm{Aa} \\
(2,40)\end{array}$ & $\begin{array}{c}20,5 \\
(1,70)\end{array}$ \\
\hline Média & $\begin{array}{l}16,8 \mathrm{~B} \\
(1,70)\end{array}$ & $\begin{array}{c}24,2 \mathrm{~A} \\
(1,70)\end{array}$ & 20,5 \\
\hline \multicolumn{4}{|c|}{ \%Material morto } \\
\hline 30 & $\begin{array}{c}13,7 \mathrm{Bb} \\
(2,02)\end{array}$ & $\begin{array}{c}19,0 \mathrm{Aa} \\
(2,02)\end{array}$ & $\begin{array}{c}16,4 \\
(1,43)\end{array}$ \\
\hline 50 & $\begin{array}{c}20,7 \mathrm{Aa} \\
(2,02)\end{array}$ & $\begin{array}{c}18,1 \mathrm{Aa} \\
(2,02)\end{array}$ & $\begin{array}{c}19,4 \\
(1,43)\end{array}$ \\
\hline Média & $\begin{array}{l}17,2 \\
(1,43)\end{array}$ & $\begin{array}{c}18,6 \\
(1,43)\end{array}$ & 17,9 \\
\hline
\end{tabular}

Números entre parênteses correspondem ao erro padrão da média.

Médias na mesma coluna seguidas de mesma letra minúscula não diferem entre si $(\mathrm{P}>0,10)$.

Médias na mesma linha seguidas de mesma letra maiúscula não diferem entre si $(P>0,10)$. 
Tabela 14. Composição morfológica média (\%) da massa de forragem na condição de pré-pastejo durante as épocas do ano

\begin{tabular}{ccccc}
\hline $\begin{array}{c}\text { Componente } \\
(\%)\end{array}$ & Verão & $\begin{array}{c}\text { Época do ano } \\
\text { Outono/Inverno }\end{array}$ & Primavera & Média \\
\hline Folhas & $64,6 \mathrm{~A}$ & $57,3 \mathrm{~B}$ & $62,9 \mathrm{~A}$ & 61,6 \\
& $(0,67)$ & $(2,27)$ & $(2,40)$ & \\
Hastes & $28,1 \mathrm{~A}$ & $18,4 \mathrm{~A}$ & $15,0 \mathrm{~B}$ & 20,5 \\
& $(4,04)$ & $(1,16)$ & $(0,91)$ & \\
Material & $15,1 \mathrm{~B}$ & $15,9 \mathrm{~A}$ & $22,7 \mathrm{~A}$ & 17,9 \\
morto & $(1,75)$ & $(1,75)$ & $(1,75)$ & \\
\hline
\end{tabular}

Números entre parênteses correspondem ao erro padrão da média.

Médias na mesma linha seguidas de mesma letra maiúscula não diferem entre si $(\mathrm{P}>0,10)$.

A proporção de lâminas foliares dos tratamentos com resíduo de $50 \mathrm{~cm}$ foi mais afetada pela época do ano que a dos tratamentos com resíduo de $30 \mathrm{~cm}$, com o valor mais baixo tendo sido verificado no outono/inverno $(50,6 \%)$ (Tabela 15). Essa redução foi de 10 pontos percentuais relativamente ao verão, enquanto que para os tratamentos com $30 \mathrm{~cm}$ de resíduo a proporção de lâminas foliares permaneceu relativamente constante (64 a 67\%). O comportamento dos tratamentos com $30 \mathrm{~cm}$ de resíduo foi dependente da alta proporção de lâminas foliares presente no tratamento 30/95 (71\%), que se manteve verde por mais tempo durante o ano.

Tabela 15. Proporção de lâminas foliares da massa de forragem em pré-pastejo para os tratamentos de resíduo 30 e $50 \mathrm{~cm}$

\begin{tabular}{ccccc}
\hline \multirow{2}{*}{ Resíduo $(\mathrm{cm})$} & Verão & $\begin{array}{c}\text { Épocas do ano } \\
\text { Outono/Inverno }\end{array}$ & Primavera & Média \\
\hline 30 & $66,6 \mathrm{Aa}$ & $64,0 \mathrm{Aa}$ & $66,2 \mathrm{Aa}$ & $65,6 \mathrm{a}$ \\
& $(0,95)$ & $(3,22)$ & $(3,40)$ & $(2,20)$ \\
50 & $62,6 \mathrm{Ab}$ & $50,6 \mathrm{Bb}$ & $59,6 \mathrm{Ab}$ & $57,6 \mathrm{~b}$ \\
& $(0,95)$ & $(3,22)$ & $(3,40)$ & $(2,20)$ \\
Média & $64,6 \mathrm{~A}$ & $57,3 \mathrm{~B}$ & $62,9 \mathrm{~A}$ & 61,6 \\
& $(0,67)$ & $(2,27)$ & $(2,40)$ & \\
\hline
\end{tabular}

Números entre parênteses correspondem ao erro padrão da média.

Médias na mesma coluna seguidas de mesma letra minúscula não diferem entre si $(\mathrm{P}>0,10)$.

Médias na mesma linha seguidas de mesma letra maiúscula não diferem entre si $(P>0,10)$. 


\subsection{4 Índice de área foliar (IAF)}

A massa de forragem e sua composição morfológica afetaram diretamente os valores de índice de área foliar do dossel. Houve efeito de resíduo $(\mathrm{P}<0,0001)$, interceptação luminosa $(\mathrm{P}<0,0001)$, época do ano $(\mathrm{P}<0,0001)$ e fase de rebrotação $(\mathrm{P}<0,0001)$, além das interações resíduo x interceptação luminosa $\mathrm{x}$ fase de rebrotação $(\mathrm{P}=0,0499)$ e fase de rebrotação $\mathrm{x}$ época do ano $(\mathrm{P}<0,0001)$.

No início do período de rebrotação (fase1), dossel em condição de pós-pastejo, o tratamento 50/95 apresentou o maior valor de IAF $(2,17)$ (Tabela 16). Os tratamentos com resíduo de $30 \mathrm{~cm}$ foram os que iniciaram a rebrotação com o menor IAF. Na fase 2, os valores de IAF para tratamentos com o mesmo resíduo se equipararam, permanecendo apenas as diferenças entre resíduos. O valor de IAF médio da fase 2 $(2,40)$ foi maior que o da fase $1(1,66)$. Já na fase 3 , os valores voltaram a se tornar diferenciados. Isso porque, apesar da fase comparada indicar o início da fase final de rebrotação, esses pontos ocorreram em alturas diferentes de dossel para os tratamentos com 95 e $100 \%$ de IL. É importante salientar que 95\% de IL foi obtido na fase 3 para os tratamentos de $100 \%$ de IL e na fase 4 para os tratamentos de $95 \%$ de IL (item 3.3). Com relação ao resíduo, os tratamentos de $30 \mathrm{~cm}$ apresentaram um IAF menor $(3,50)$ que os de $50 \mathrm{~cm}(3,92)$ na fase 3 , de forma semelhante às fases 1 e 2 . Finalmente, na fase 4, correspondente ao início do pastejo, a diferença entre resíduos desapareceu quando se considerou a interceptação luminosa de 95\% (4,23), ou seja, independente da condição de início da rebrotação (resíduo de 30 ou $50 \mathrm{~cm}$ ), o IAF no momento do pastejo quando o dossel atingiu 95\% de IL foi o mesmo (Tabela 16). 
Tabela 16. Evolução do índice de área foliar do dossel forrageiro de capim-Mombaça durante o período de rebrotação

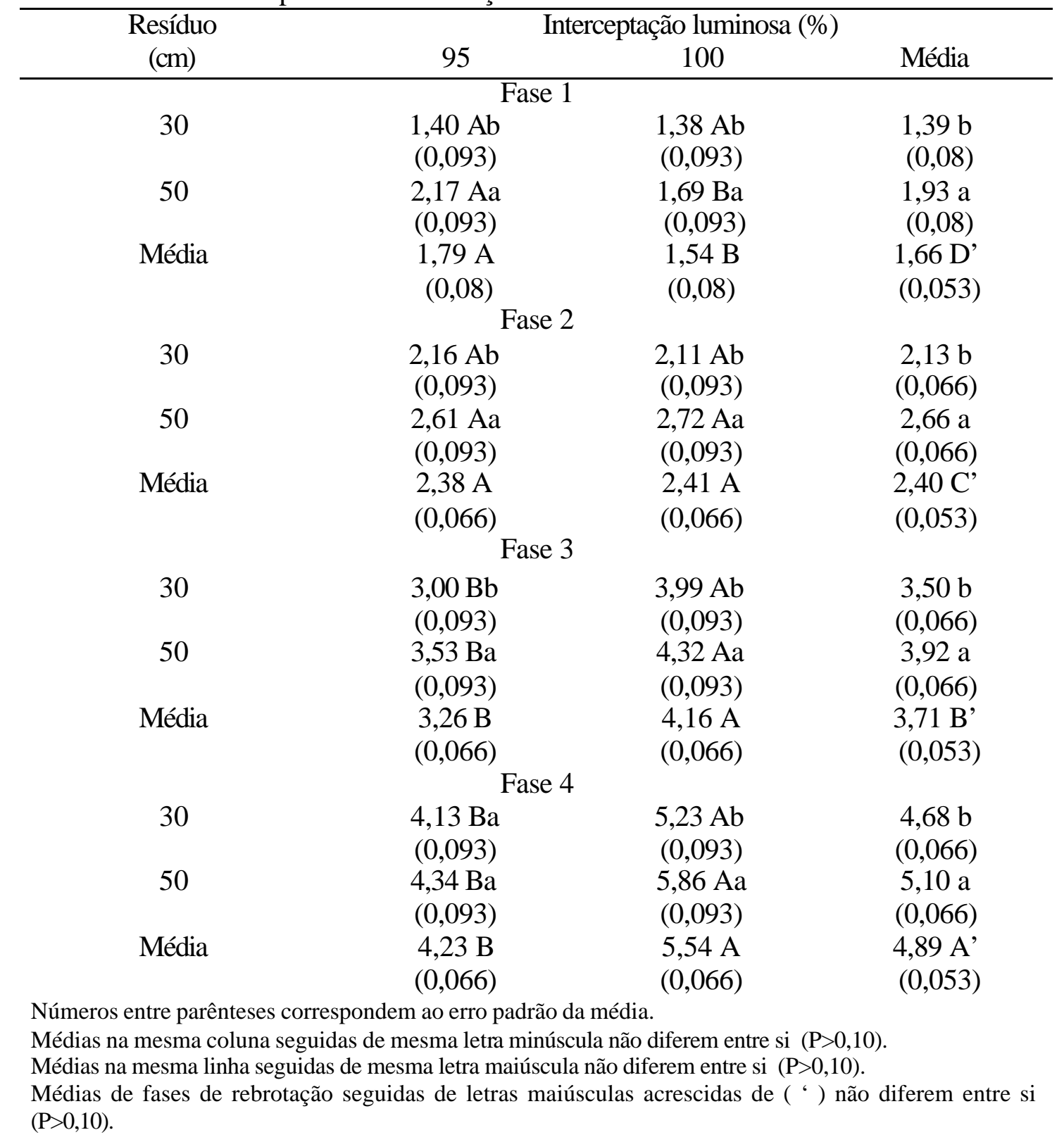

Na Figura 14 é possível visualizar o comportamento e a evolução do IAF desde o momento da saída dos animais dos pastos (fase 1) até o próximo pastejo (fase 4) em todos os tratamentos. 


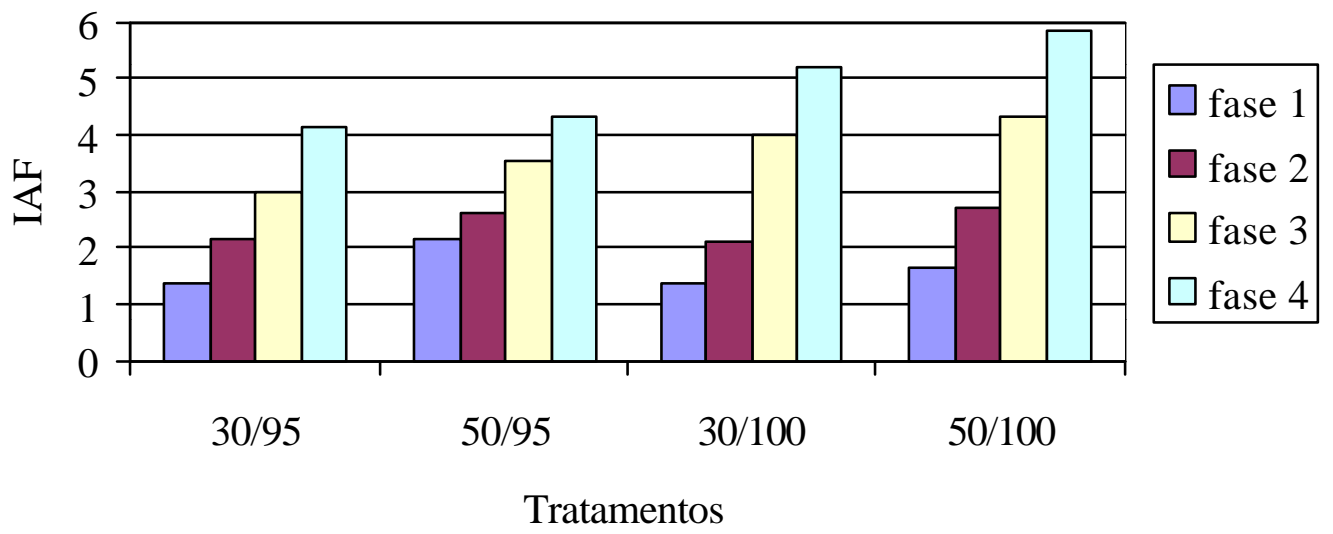

Figura 14- Evolução do IAF do dossel forrageiro durante a rebrotação do capimMombaça para os tratamentos experimentais (média do período experimental)

Os valores de IAF foram mais elevados em todas as fases de rebrotação durante o período do outono/inverno (Tabela 17).

Tabela 17. Evolução do IAF do dossel forrageiro de capim-Mombaça durante o período de rebrotação nas épocas do ano

\begin{tabular}{ccccc}
\hline Epocas do ano & \multicolumn{4}{c}{ Fases de rebrotação } \\
& 1 & 2 & 3 & 4 \\
\hline Verão & $1,49 \mathrm{Db}$ & $2,20 \mathrm{Cb}$ & $3,69 \mathrm{Bb}$ & $4,73 \mathrm{Ab}$ \\
& $(0,093)$ & $(0,093)$ & $(0,093)$ & $(0,093)$ \\
Outono/Inverno & $1,81 \mathrm{Da}$ & $2,90 \mathrm{Ca}$ & $3,92 \mathrm{Ba}$ & $5,09 \mathrm{Aa}$ \\
& $(0,093)$ & $(0,093)$ & $(0,093)$ & $(0,093)$ \\
Primavera & $1,68 \mathrm{Dab}$ & $2,10 \mathrm{Cb}$ & $3,53 \mathrm{Bb}$ & $4,84 \mathrm{Ab}$ \\
& $(0,093)$ & $(0,093)$ & $(0,093)$ & $(0,093)$ \\
Média & $1,66 \mathrm{D}$ & $2,40 \mathrm{C}$ & $3,71 \mathrm{~B}$ & $4,89 \mathrm{~A}$ \\
& $(0,053)$ & $(0,053)$ & $(0,053)$ & $(0,053)$
\end{tabular}

Números entre parênteses correspondem ao erro padrão da média.

Médias na mesma coluna seguidas de mesma letra minúscula não diferem entre si $(\mathrm{P}>0,10)$.

Médias na mesma linha seguidas de mesma letra maiúscula não diferem entre si $(P>0,10)$.

$\mathrm{Na}$ condição de pré-pastejo (fase 4), houve efeito de resíduo $(\mathrm{P}=0,0428)$, interceptação luminosa $(\mathrm{P}<0,0001)$ e época do ano $(\mathrm{P}=0,0845)$. Na Tabela 16 , observase que os tratamentos com 95\% de IL resultaram em menores valores de IAF $(4,23)$ que 
os tratamentos de $100 \%$ IL (5,54). Adicionalmente, os tratamentos com resíduo de 30 $\mathrm{cm}$ proporcionaram um valor de IAF em pré-pastejo $(4,68)$ inferior àquele dos tratamentos com resíduo de $50 \mathrm{~cm}(5,10)$. Assim como o IAF na condição de pós-pastejo (fase 1), o IAF em pré-pastejo (fase 4) também foi semelhante entre a primavera $(4,84)$ e o verão $(4,73)$, aumentando no outono/inverno $(5,09)$.

\subsection{5 Ângulo da folhagem}

Houve efeito de resíduo $(\mathrm{P}=0,0022)$, interceptação luminosa $(\mathrm{P}=0,0067)$, fase de rebrotação $(\mathrm{P}<0,0001)$ e época do ano $(\mathrm{P}=0,0003)$, além das interações resíduo $x$ fase de rebrotação $(\mathrm{P}<0,0001)$, interceptação luminosa $\mathrm{x}$ fase de rebrotação $(\mathrm{P}<0,0001)$, época do ano $\mathrm{x}$ fase de rebrotação $(\mathrm{P}<0,0001)$, resíduo $\mathrm{x}$ época do ano $\mathrm{x}$ fase de rebrotação $(\mathrm{P}=0,0343)$ e resíduo $\mathrm{x}$ interceptação luminosa $\mathrm{x}$ época do ano $\mathrm{x}$ fase de rebrotação $(\mathrm{P}=0,0797)$.

No verão, a rebrotação foi iniciada com condições de dossel semelhantes quanto ao ângulo da folhagem para os tratamentos de 95 e 100\% de IL (Tabela 19). Os tratamentos de $30 \mathrm{~cm}$ apresentaram maiores valores de ângulo da folhagem $\left(67,9^{\circ}\right)$ que os tratamentos de $50 \mathrm{~cm}\left(62,7^{\circ}\right)$. No primeiro terço da rebrotação (Fase 2), o mesmo padrão de comportamento foi registrado entre os tratamentos de resíduo 30 e $50 \mathrm{~cm}$, porém as diferenças diminuíram. A partir do segundo terço da rebrotação (fase 3) os tratamentos de interceptação luminosa passaram a influenciar o ângulo da folhagem. $O$ dossel dos tratamentos de $95 \%$ de IL apresentouse mais ereto que o dossel de $100 \%$ de IL. O tratamento 30/95 resultou em um dossel de arquitetura mais ereta $\left(57,8^{\circ}\right)$ que os demais tratamentos $\left(47,8^{\circ}\right.$ a $\left.54,3^{\circ}\right)$. Os tratamentos de $100 \%$ de IL já se apresentavam como os menos eretos nessa fase $\left(52,8^{\circ}\right.$ a $\left.47,8^{\circ}\right)$. Finalmente, na condição de pré-pastejo (fase 4), os tratamentos de $95 \%$ de IL apresentaram dossel mais ereto $\left(52,3^{\circ}\right)$ que os tratamentos com $100 \%$ de IL $\left(45^{\circ}\right)$, tendo o tratamento 30/100 apresentado o dossel menos ereto $\left(44^{\circ}\right)$. 
Tabela 19. Evolução do ângulo da folhagem (graus) durante a rebrotação do capimMombaça no verão

\begin{tabular}{|c|c|c|c|c|}
\hline \multirow[b]{2}{*}{ Resíduo (cm) } & & \multicolumn{3}{|c|}{ Interceptação luminosa (\%) } \\
\hline & & 95 & 100 & Média \\
\hline \multirow[t]{6}{*}{ Fase 1} & 30 & $67,0 \mathrm{Aa}$ & $68,8 \mathrm{Aa}$ & $67,9 \mathrm{a}$ \\
\hline & & $(1,52)$ & $(1,52)$ & $(1,08)$ \\
\hline & 50 & $63,0 \mathrm{Ab}$ & $62,3 \mathrm{Ab}$ & $62,7 \mathrm{~b}$ \\
\hline & & $(1,52)$ & $(1,52)$ & $(1,08)$ \\
\hline & Média & $65,0 \mathrm{~A}$ & $67,0 \mathrm{~A}$ & $65,3 A^{\prime}$ \\
\hline & & $(1,08)$ & $(1,08)$ & $(0,76)$ \\
\hline \multicolumn{5}{|l|}{ Fase 2} \\
\hline & 30 & $62,5 \mathrm{Aa}$ & $63,5 \mathrm{Aa}$ & $63,0 \mathrm{a}$ \\
\hline & & $(1,03)$ & $(1,03)$ & $(0,73)$ \\
\hline & 50 & $61,3 \mathrm{Aa}$ & $59,8 \mathrm{Aa}$ & $60,5 \mathrm{~b}$ \\
\hline & & $(1,03)$ & $(1,03)$ & $(0,73)$ \\
\hline & Média & $61,9 \mathrm{~A}$ & $61,6 \mathrm{~A}$ & $61,8 \mathrm{~B}$ \\
\hline & & $(0,73)$ & $(0,73)$ & $(0,52)$ \\
\hline \multicolumn{5}{|l|}{ Fase 3} \\
\hline & 30 & $57,8 \mathrm{Aa}$ & $52,8 \mathrm{Ba}$ & $55,3 \mathrm{a}$ \\
\hline & & $(0,86)$ & $(0,86)$ & $(0,61)$ \\
\hline & 50 & $54,3 \mathrm{Ab}$ & $47,8 \mathrm{Bb}$ & $51,0 \mathrm{~b}$ \\
\hline & & $(0,86)$ & $(0,86)$ & $(0,61)$ \\
\hline & Média & $56,0 \mathrm{~A}$ & $50,3 \mathrm{~B}$ & $53,2 C^{\prime}$ \\
\hline & & $(0,61)$ & $(0,61)$ & $(0,43)$ \\
\hline \multicolumn{5}{|l|}{ Fase 4} \\
\hline & 30 & $53,3 \mathrm{Aa}$ & $44,0 \mathrm{Ba}$ & $48,6 \mathrm{a}$ \\
\hline & & $(0,86)$ & $(0,86)$ & $(0,61)$ \\
\hline & 50 & $51,3 \mathrm{Ab}$ & $46,0 \mathrm{Bb}$ & $48,6 \mathrm{a}$ \\
\hline & & $(0,86)$ & $(0,86)$ & $(0,61)$ \\
\hline & Média & $52,3 \mathrm{~A}$ & $45,0 \mathrm{~B}$ & $48,6 \mathrm{D}$ \\
\hline & & $(0,61)$ & $(0,61)$ & $(0,43)$ \\
\hline
\end{tabular}

Números entre parênteses correspondem ao erro padrão da média.

Médias na mesma coluna seguidas de mesma letra minúscula não diferem entre si $(\mathrm{P}>0,10)$.

Médias na mesma linha seguidas de mesma letra maiúscula não diferem entre si $(P>0,10)$.

No outono/inverno (Tabela 20) e na primavera (Tabela 21) foi registrado o mesmo comportamento do verão, apesar de os valores de ângulo da folhagem terem sido numericamente diferentes. De uma forma geral, no outono/inverno os valores de ângulo da folhagem foram semelhantes. Na primavera, houve aumento dos valores de ângulo da folhagem, porém as diferenças não foram superiores a três graus. 
Tabela 20. Evolução do ângulo da folhagem (graus) durante a rebrotação do capimMombaça no outono/inverno

\begin{tabular}{|c|c|c|c|c|}
\hline \multirow[b]{2}{*}{ Resíduo (cm) } & & \multicolumn{3}{|c|}{ Interceptação luminosa (\%) } \\
\hline & & 95 & 100 & Média \\
\hline \multirow[t]{6}{*}{ Fase 1} & 30 & $71,8 \mathrm{Aa}$ & $72,8 \mathrm{Aa}$ & $72,3 \mathrm{a}$ \\
\hline & & $(2,28)$ & $(2,28)$ & $(1,61)$ \\
\hline & 50 & $60,8 \mathrm{Ab}$ & $61,0 \mathrm{Ab}$ & $60,9 b$ \\
\hline & & $(2,28)$ & $(2,28)$ & $(1,61)$ \\
\hline & Média & $66,3 \mathrm{~A}$ & $66,9 \mathrm{~A}$ & $66,6 A^{\prime}$ \\
\hline & & $(1,61)$ & $(1,61)$ & $(1,14)$ \\
\hline \multicolumn{5}{|l|}{ Fase 2} \\
\hline & 30 & $58,3 \mathrm{Aa}$ & $61,0 \mathrm{Aa}$ & $59,6 \mathrm{a}$ \\
\hline & & $(1,20)$ & $(1,20)$ & $(0,85)$ \\
\hline & 50 & $56,5 \mathrm{Aa}$ & $56,5 \mathrm{Aa}$ & $56,5 \mathrm{~b}$ \\
\hline & & $(1,20)$ & $(1,20)$ & $(0,85)$ \\
\hline & Média & $57,4 \mathrm{~A}$ & $58,8 \mathrm{~A}$ & $58,6 \mathrm{~B}^{\prime}$ \\
\hline & & $(0,85)$ & $(0,85)$ & $(0,60)$ \\
\hline \multicolumn{5}{|l|}{ Fase 3} \\
\hline & 30 & $57,0 \mathrm{Aa}$ & 49,8 Ba & $53,4 \mathrm{a}$ \\
\hline & 50 & $56,3 \mathrm{Aa}$ & $51,8 \mathrm{Ba}$ & $54,0 \mathrm{a}$ \\
\hline & & $(1,40)$ & $(1,40)$ & $(0,99)$ \\
\hline & Média & $56,6 \mathrm{~A}$ & $50,8 \mathrm{~B}$ & $53,7 C^{\prime}$ \\
\hline & & $(0,99)$ & $(0,99)$ & $(0,70)$ \\
\hline \multicolumn{5}{|l|}{ Fase 4} \\
\hline & 30 & $51,5 \mathrm{Aa}$ & $46,0 \mathrm{Bb}$ & $48,8 \mathrm{~b}$ \\
\hline & & $(1,17)$ & $(1,17)$ & $(0,82)$ \\
\hline & 50 & $52,5 \mathrm{Aa}$ & $49,3 \mathrm{Aa}$ & $50,9 \mathrm{a}$ \\
\hline & & $(1,17)$ & $(1,17)$ & $(0,82)$ \\
\hline & Média & $52,0 \mathrm{~A}$ & $47,6 \mathrm{~B}$ & 49,8 D' \\
\hline & & $(0,82)$ & $(0,82)$ & $(0,58)$ \\
\hline
\end{tabular}

Números entre parênteses correspondem ao erro padrão da média.

Médias na mesma coluna seguidas de mesma letra minúscula não diferem entre si $(P>0,10)$.

Médias na mesma linha seguidas de mesma letra maiúscula não diferem entre si $(\mathrm{P}>0,10)$. 
Tabela 21. Evolução do ângulo da folhagem (graus) durante a rebrotação do capimMombaça na primavera

\begin{tabular}{|c|c|c|c|c|}
\hline \multirow[b]{2}{*}{ Resíduo (cm) } & & \multicolumn{3}{|c|}{ Interceptação luminosa (\%) } \\
\hline & & 95 & 100 & Média \\
\hline \multirow[t]{5}{*}{ Fase 1} & 30 & $71,0 \mathrm{Aa}$ & $70,8 \mathrm{Aa}$ & $70,9 \mathrm{a}$ \\
\hline & 50 & $64,0 \mathrm{Ab}$ & $67,5 \mathrm{Aa}$ & $65,8 \mathrm{~b}$ \\
\hline & & $(2,55)$ & $(2,55)$ & $(1,08)$ \\
\hline & Média & $67,5 \mathrm{~A}$ & $69,1 \mathrm{~A}$ & $68,3 \mathrm{~A}^{\prime}$ \\
\hline & & $(1,08)$ & $(1,08)$ & $(1,27)$ \\
\hline \multicolumn{5}{|l|}{ Fase 2} \\
\hline & 30 & 66,3 Aa & $67,8 \mathrm{Aa}$ & $67,0 \mathrm{a}$ \\
\hline & & $(2,25)$ & $(2,25)$ & $(1,59)$ \\
\hline & 50 & $62,5 \mathrm{Aa}$ & $69,8 \mathrm{Aa}$ & $66,1 \mathrm{a}$ \\
\hline & & $(2,25)$ & $(2,25)$ & $(1,59)$ \\
\hline & Média & $64,4 \mathrm{~B}$ & $68,8 \mathrm{~A}$ & $66,6 \mathrm{~A}^{\prime}$ \\
\hline & & $(1,59)$ & $(1,59)$ & $(1,12)$ \\
\hline \multicolumn{5}{|l|}{ Fase 3} \\
\hline & 30 & $55,3 \mathrm{Aa}$ & $51,0 \mathrm{Ba}$ & $53,1 \mathrm{a}$ \\
\hline & & $(0,69)$ & $(0,69)$ & $(0,49)$ \\
\hline & 50 & $55,5 \mathrm{Ab}$ & $52,5 \mathrm{Bb}$ & $54,0 \mathrm{~b}$ \\
\hline & & $(0,69)$ & $(0,69)$ & $(0,49)$ \\
\hline & Média & $55,4 \mathrm{~A}$ & $51,8 \mathrm{~B}$ & $53,6 \mathrm{~B}^{\prime}$ \\
\hline & & $(0,49)$ & $(0,49)$ & $(0,35)$ \\
\hline \multicolumn{5}{|l|}{ Fase 4} \\
\hline & 30 & $54,3 \mathrm{Aa}$ & $48,3 \mathrm{Ba}$ & $51,3 \mathrm{a}$ \\
\hline & & $(1,72)$ & $(1,72)$ & $(1,22)$ \\
\hline & 50 & $54,3 \mathrm{Aa}$ & $47,8 \mathrm{Ba}$ & $51,0 \mathrm{a}$ \\
\hline & & $(1,72)$ & $(1,72)$ & $(1,22)$ \\
\hline & Média & $54,3 \mathrm{~A}$ & $48,0 \mathrm{~B}$ & $51,1 C^{\prime}$ \\
\hline & & $(1,22)$ & $(1,22)$ & $(0,86)$ \\
\hline
\end{tabular}

Números entre parênteses correspondem ao erro padrão da média.

Médias na mesma coluna seguidas de mesma letra minúscula não diferem entre si $(P>0,10)$.

Médias na mesma linha seguidas de mesma letra maiúscula não diferem entre si $(\mathrm{P}>0,10)$. 


\subsubsection{Interceptação luminosa}

A interceptação luminosa do dossel forrageiro foi utilizada como determinante da condição de entrada dos animais nos pastos para início do pastejo. Assim, os valores da fase 4 (pré-pastejo) não são variáveis-resposta como o são os das fases 1 (resíduo pós-pastejo), 2 (primeiro terço da rebrotação) e 3 (segundo terço da rebrotação). Houve efeito de resíduo $(\mathrm{P}<0,0001)$, interceptação luminosa $(\mathrm{P}=0,1056)$, fase de rebrotação $(\mathrm{P}<0,0001)$ e época do ano $(\mathrm{P}<0,0001)$, além das interações resíduo $\mathrm{x}$ fase de rebrotação $\mathrm{x}$ época do ano $(\mathrm{P}=0,0392)$ e interceptação luminosa $\mathrm{x}$ fase de rebrotação $\mathrm{x}$ época do ano $(\mathrm{P}=0,0372)$.

Os valores de interceptação luminosa do dossel forrageiro dos tratamentos com resíduo de $30 \mathrm{~cm}$ foram menores que aqueles dos tratamentos de resíduo $50 \mathrm{~cm}$ em todas as fases de rebrotação e épocas do ano (Tabela 22). Os valores de interceptação luminosa dos tratamentos de $95 \%$ e $100 \%$ IL apresentaram variações menores (Tabela 23). A diferença entre os tratamentos aparece no final da fase de rebrotação (fase 4) por ocasião da determinação do ponto de entrada dos animais. Não houve diferença entre as estações do ano. 
Tabela 22. Evolução da interceptação luminosa (\%) do dossel forrageiro de capimMombaça durante o período de rebrotação para os tratamentos \& 30 e 50 cm de resíduo nas épocas do ano

\begin{tabular}{|c|c|c|c|c|}
\hline \multirow[b]{2}{*}{ Resíduo (cm) } & \multicolumn{4}{|c|}{ Fase de rebrotação } \\
\hline & 1 & 2 & 3 & 4 \\
\hline & & Verão & & \\
\hline 30 & $\begin{array}{c}59,3 \mathrm{Db} \\
(1,22)\end{array}$ & $\begin{array}{c}72,6 \mathrm{Cb} \\
(1,91)\end{array}$ & $\begin{array}{c}90,5 \mathrm{Bb} \\
(1,03)\end{array}$ & $\begin{array}{c}96,8 \mathrm{Ab} \\
(0,12)\end{array}$ \\
\hline 50 & $71,3 \mathrm{Da}$ & $82,0 \mathrm{Ca}$ & $94,1 \mathrm{Ba}$ & 97,3 Aa \\
\hline & $(1,22)$ & $(1,91)$ & $(1,03)$ & $(0,12)$ \\
\hline Média & $\begin{array}{c}65,3 \mathrm{D} \\
(0,87)\end{array}$ & $\begin{array}{l}77,3 \mathrm{C} \\
(1,35)\end{array}$ & $\begin{array}{c}92,3 \mathrm{~B} \\
(0,73)\end{array}$ & $\begin{array}{c}97,0 \mathrm{~A}^{\prime} \\
(0,73)\end{array}$ \\
\hline \multicolumn{5}{|c|}{ Outono/Inverno } \\
\hline 30 & $\begin{array}{c}63,2 \mathrm{Db} \\
(2,00)\end{array}$ & $\begin{array}{c}84,0 \mathrm{Cb} \\
(1,18)\end{array}$ & $\begin{array}{c}92,5 \mathrm{Bb} \\
(0,75)\end{array}$ & $\begin{array}{c}97,2 \mathrm{Aa} \\
(0,27)\end{array}$ \\
\hline 50 & $\begin{array}{c}78,3 \mathrm{Da} \\
(2,00)\end{array}$ & $\begin{array}{c}89,8 \mathrm{Ca} \\
(1,18)\end{array}$ & $\begin{array}{c}94,3 \mathrm{Ba} \\
(0,75)\end{array}$ & $\begin{array}{c}97,5 \mathrm{Aa} \\
(0,27)\end{array}$ \\
\hline Média & $\begin{array}{l}70,8 \mathrm{D} \\
(1,41)\end{array}$ & $\begin{array}{l}86,9 \mathrm{C} \\
(0,83)\end{array}$ & $\begin{array}{c}93,4 \mathrm{~B} \\
(0,53)\end{array}$ & $\begin{array}{c}97,4 \mathrm{~A}^{\prime} \\
(0,19)\end{array}$ \\
\hline \multicolumn{5}{|c|}{ Primavera } \\
\hline 30 & $\begin{array}{c}60,1 \mathrm{Db} \\
(1,83)\end{array}$ & $\begin{array}{c}70,2 \mathrm{Cb} \\
(1,81)\end{array}$ & $\begin{array}{c}90,6 \mathrm{Bb} \\
(0,93)\end{array}$ & $\begin{array}{c}96,4 \mathrm{Ab} \\
(0,25)\end{array}$ \\
\hline 50 & $\begin{array}{c}72,9 \mathrm{Da} \\
(1,83)\end{array}$ & $\begin{array}{c}79,3 \mathrm{Ca} \\
(1,81)\end{array}$ & $\begin{array}{c}93,7 \mathrm{Ba} \\
(0,93)\end{array}$ & $\begin{array}{c}97,2 \mathrm{Aa} \\
(0,25)\end{array}$ \\
\hline Média & $\begin{array}{c}66,5 \mathrm{D} \\
(1,30)\end{array}$ & $\begin{array}{l}74,8 \mathrm{C} \\
(1,28)\end{array}$ & $\begin{array}{l}92,1 \mathrm{~B} \\
(0,66)\end{array}$ & $\begin{array}{c}96,8 \mathrm{~A} \\
(0,18)\end{array}$ \\
\hline Média de Fases & $\begin{array}{c}67,5 \mathrm{D} \\
(0,71)\end{array}$ & $\begin{array}{l}79,6 \mathrm{C} \\
(0,68)\end{array}$ & $\begin{array}{c}92,6 \mathrm{~B} \\
(0,37)\end{array}$ & $\begin{array}{r}97,1 \mathrm{~A}^{\prime} \\
(0,09)\end{array}$ \\
\hline
\end{tabular}

Números entre parênteses correspondem ao erro padrão da média.

Médias na mesma coluna seguidas de mesma letra minúscula não diferem entre si $(\mathrm{P}>0,10)$.

Médias na mesma linha seguidas de mesma letra maiúscula não diferem entre si $(\mathrm{P}>0,10)$.

Médias de épocas do ano seguidas de letras maiúsculas acrescidas de ( ') não diferem entre si (P>0,10). 
Tabela 23. Evolução da interceptação luminosa (\%) do dossel forrageiro de capimMombaça durante o período de rebrotação para os tratamentos com 95 e $100 \%$ de interceptação luminosa nas épocas do ano

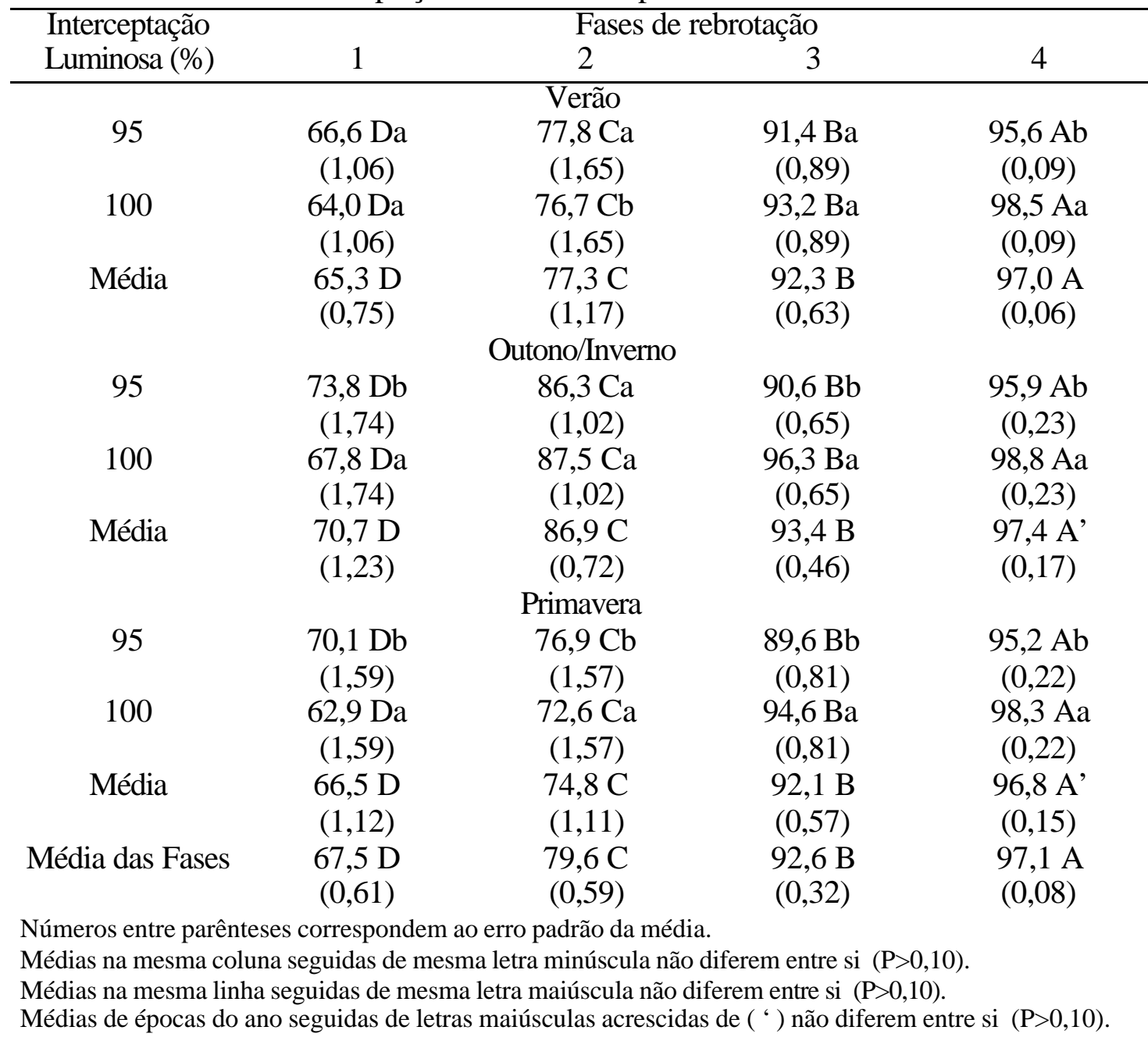

O comportamento da evolução da interceptação luminosa pelo dossel forrageiro foi consistente durante todas as épocas do ano. Na fise 1, os tratamentos de $95 \%$ de IL interceptaram mais luz que os tratamentos de $100 \%$ de IL. Na fase 2, os valores de interceptação luminosa se equipararam e não existiram diferenças entre os tratamentos. Nas fases 3 e 4, os valores de interceptação luminosa dos tratamentos de $100 \%$ de IL passaram a ser superiores em relação aos tratamentos de 95\% de IL. No verão essa diferença não existiu durante a fase 3 do processo de rebrotação. 
A análise visual dos dados plotados de IAF e interceptação luminosa do dossel forrageiro revelou forte associação positiva entre essas duas variáveis, como pode ser visualizado na Figura 15. A altura do dossel forrageiro também apresentou uma forte relação positiva com a interceptação luminosa (Figura 16).

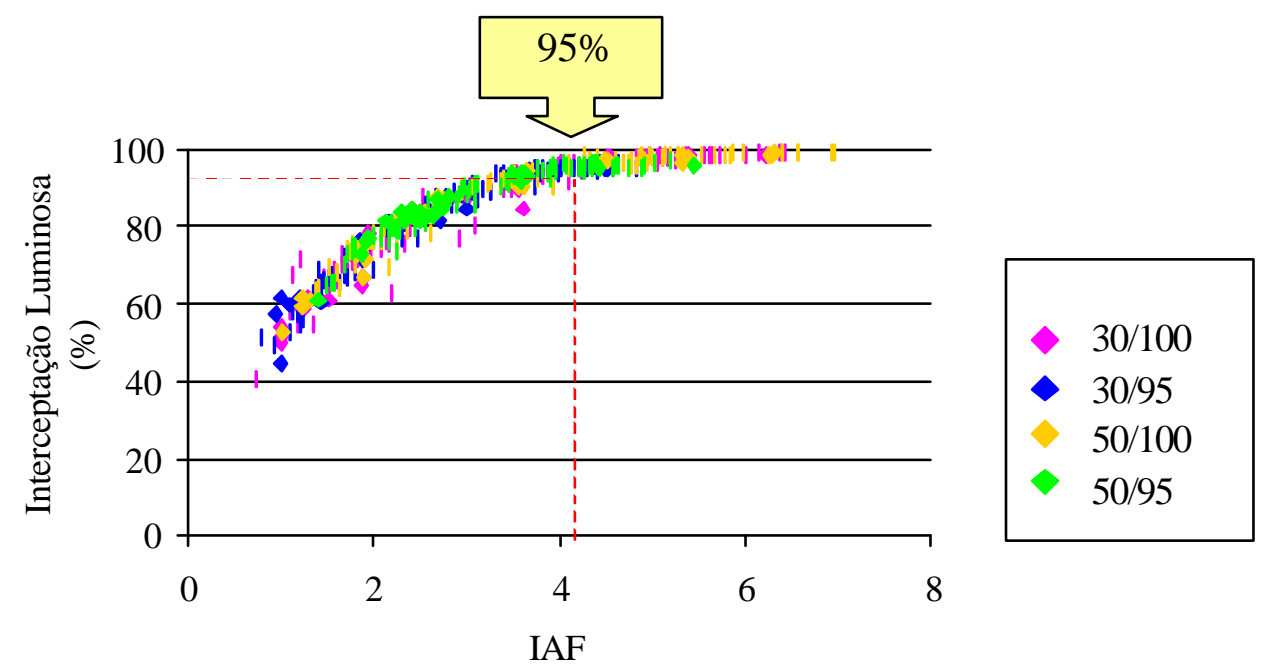

Figura 15- Relação entre índice de área foliar e interceptação luminosa do dossel forrageiro de capim-Mombaça submetido a regimes de pastejo intermitente durante o ano

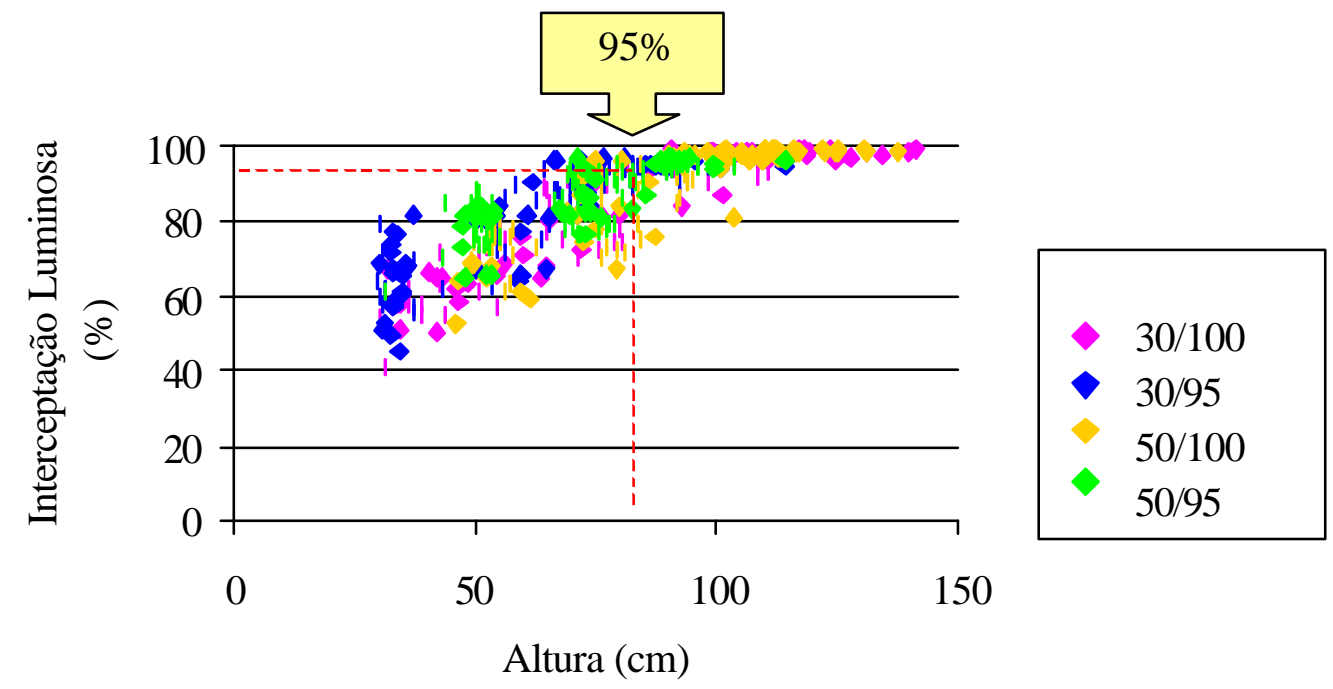

Figura 16- Relação entre altura e interceptação luminosa do dossel forrageiro de capimMombaça submetido a regimes de pastejo intermitente durante o ano 
A partir dos dados de IAF, interceptação luminosa e altura do dossel forrageiro foram ajustadas curvas aos valores de IAF e IL (Figura 17) e Altura do dossel e IL (Figura 18) que descreveram a relação funcional entre as variáveis estudadas. O padrão de comportamento da interceptação luminosa em relação ao IAF e à altura do dossel forrageiro foi análogo, indicando uma assíntota a partir dos 95\% de IL pelo dossel forrageiro.

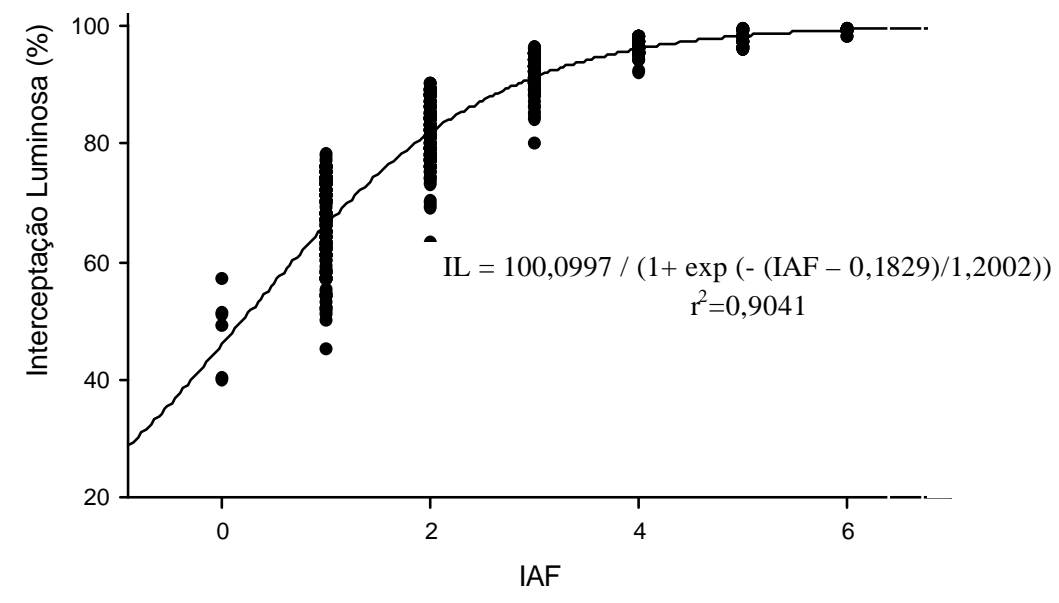

Figura 17- Relação entre interceptação luminosa e IAF em pastos de capim-Mombaça submetidos a regimes de pastejo intermitente 


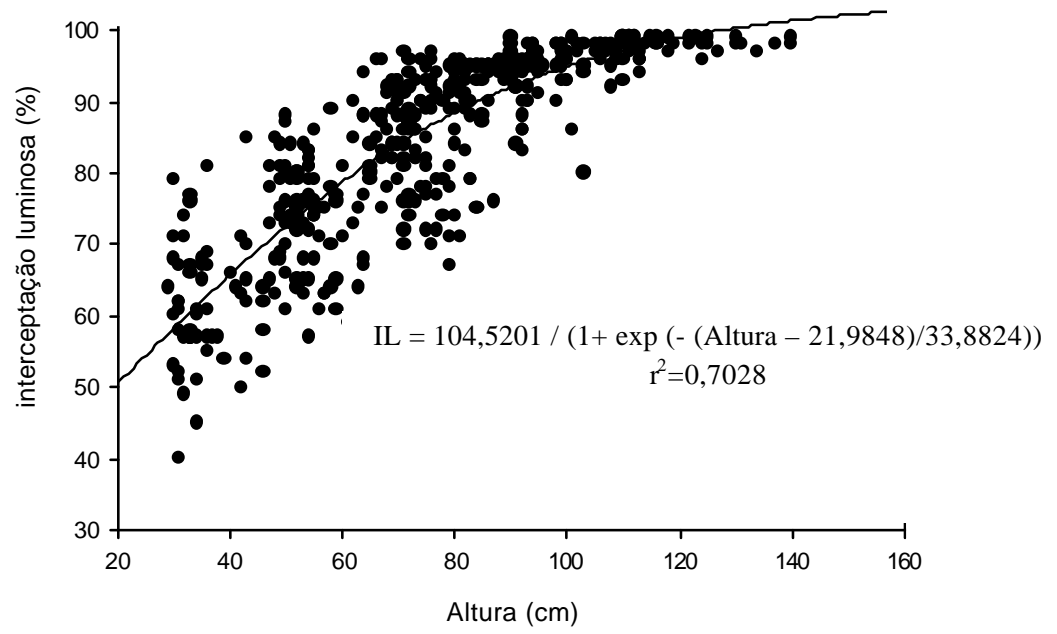

Figura 18- Relação entre altura e interceptação luminosa no dossel forrageiro de pastos de capim-Mombaça submetidos a regimes de pastejo intermitente

Os valores de interceptação luminosa em pré-pastejo foram utilizados como metas para interromper a rebrotação dos pastos (secção 3.2.1). Na Tabela 24 são apresentados os valores médios efetivos de interceptação luminosa alcançados durante todo o experimento. Os tratamentos de $100 \% \mathrm{IL}$, na verdade, tiveram seus pastejos iniciados com cerca de 98 a 99\% de interceptação luminosa enquanto que os de $95 \%$ de IL estiveram muito próximos da meta estipulada.

Tabela 24. Interceptação luminosa (\%) do dossel forrageiro de capim-Mombaça na condição de pré-pastejo

\begin{tabular}{ccc}
\hline & \multicolumn{2}{c}{ Interceptação luminosa (\%) } \\
Resíduo $(\mathrm{cm})$ & 95 & 100 \\
\hline 30 & 95,4 & 98,2 \\
50 & 95,7 & 98,9 \\
Média & 95,6 & 98,6 \\
\hline
\end{tabular}




\subsubsection{Densidade populacional de perfilhos}

Houve efeito de fase de rebrotação $(\mathrm{P}<0,0001)$ e época do ano $(\mathrm{P}=0,0781)$, além das interações época do ano $\mathrm{x}$ fase de rebrotação $(\mathrm{P}=0,0643)$, interceptação luminosa $\mathrm{x}$ fase de rebrotação $(\mathrm{P}=0,0274)$, resíduo $\mathrm{x}$ interceptação luminosa $\mathrm{x}$ fase de rebrotação $(\mathrm{P}=0,0899)$ e interceptação luminosa $\mathrm{x}$ resíduo $\mathrm{x}$ fase de rebrotação $\mathrm{x}$ época do ano $(\mathrm{P}=0,0029)$. As fases de rebrotação corresponderam: (a) condição de pós-pastejo, (b) meio do período de rebrotação (fase intermediária) e (c) condição de pré-pastejo (item 3.3).

Na Tabela 25 são apresentados os valores de densidade populacional de perfilhos durante o verão. Os tratamentos de $95 \%$ de IL superaram os tratamentos de $100 \%$ de IL nas condições de pós e pré-pastejo. Os tratamentos de 30 e $50 \mathrm{~cm}$ de resíduo diferiram apenas na fase de pré-pastejo do período de rebrotação durante o verão, quando a densidade populacional de perfilhos foi maior para os tratamentos com resíduo de $50 \mathrm{~cm}$ (415 x 380 perfilhos $\mathrm{m}^{-2}$ ). Houve aumento progressivo no número de perfilhos no decorrer do processo de rebrotação durante esta época do ano para os tratamentos de 95\% de IL. Para os tratamentos de $100 \%$ de IL houve aumento até a metade da rebrotação, seguido de estabilização até a condição de pré-pastejo. 
Tabela 25. Densidade populacional de perfilhos (perfilhos $\mathrm{m}^{-2}$ ) em pastos de capimMombaça submetidos a regimes de pastejo intermitente durante a rebrotação no verão

\begin{tabular}{|c|c|c|c|}
\hline \multirow[b]{2}{*}{ Resíduo (cm) } & \multicolumn{3}{|c|}{ Interceptação luminosa (\%) } \\
\hline & 95 & 100 & Média \\
\hline \multirow{3}{*}{30} & & Pós-pastej & \\
\hline & $350 \mathrm{Aa}$ & $290 \mathrm{Ba}$ & $320 \mathrm{a}$ \\
\hline & $(23,7)$ & $(23,7)$ & $(16,8)$ \\
\hline \multirow[t]{2}{*}{50} & $340 \mathrm{Aa}$ & $320 \mathrm{Aa}$ & $330 \mathrm{a}$ \\
\hline & $(23,7)$ & $(23,7)$ & $(16,8)$ \\
\hline \multirow[t]{3}{*}{ Média } & $345 \mathrm{~A}$ & $305 \mathrm{~B}$ & $325 C^{\prime}$ \\
\hline & $(16,8)$ & $(16,8)$ & $(11,9)$ \\
\hline & \multicolumn{3}{|c|}{ Fase intermediária } \\
\hline \multirow[t]{2}{*}{30} & $380 \mathrm{Aa}$ & $360 \mathrm{Aa}$ & $370 \mathrm{a}$ \\
\hline & $(28,0)$ & $(28,0)$ & $(19,8)$ \\
\hline \multirow[t]{2}{*}{50} & $390 \mathrm{Aa}$ & $400 \mathrm{Aa}$ & $395 \mathrm{a}$ \\
\hline & $(28,0)$ & $(28,0)$ & $(19,8)$ \\
\hline \multirow[t]{3}{*}{ Média } & $385 \mathrm{~A}$ & $380 \mathrm{~A}$ & $380 \mathrm{~B}^{\prime}$ \\
\hline & $(19,8)$ & $(19,8)$ & $(14,0)$ \\
\hline & & Pré-pastej & \\
\hline \multirow[t]{2}{*}{30} & $400 \mathrm{Aa}$ & $360 \mathrm{Bb}$ & $380 \mathrm{~b}$ \\
\hline & $(25,5)$ & $(25,5)$ & $(18,0)$ \\
\hline \multirow[t]{2}{*}{50} & $430 \mathrm{Aa}$ & $400 \mathrm{Aa}$ & $415 \mathrm{a}$ \\
\hline & $(25,5)$ & $(25,5)$ & $(18,0)$ \\
\hline \multirow[t]{2}{*}{ Média } & $415 \mathrm{~A}$ & $380 \mathrm{~B}$ & $400 A^{\prime}$ \\
\hline & $(18,0)$ & $(18,0)$ & $(12,7)$ \\
\hline \multirow[t]{2}{*}{ Media da Época } & & & 370 a' \\
\hline & & & $(11,8)$ \\
\hline
\end{tabular}

Números entre parênteses correspondem ao erro padrão da média.

Médias na mesma coluna seguidas de mesma letra minúscula não diferem entre si $(P>0,10)$.

Médias na mesma linha seguidas de mesma letra maiúscula não diferem entre si $(\mathrm{P}>0,10)$.

Médias de fases de rebrotação seguidas de letras maiúsculas acrescidas de ( ") não diferem entre si $(\mathrm{P}>0,10)$.

Médias de épocas do ano seguidas de letras minúsculas acrescidas de ( ' ) nas Tabelas 25, 26 e 27 não diferem entre si $(\mathrm{P}>0,10)$.

Durante o outono/inverno (período seco do ano), houve aumento no número de perfilhos até a metade da rebrotação (320 a 355 perfilhos $\mathrm{m}^{-2}$ ) e queda no final do período (335 perfilhos $\mathrm{m}^{-2}$ ) (pré-pastejo) (Tabela 26). Os tratamentos de resíduo $30 \mathrm{~cm} \mathrm{e}$ $100 \%$ de IL apresentaram os menores valores de densidade populacional de perfilhos (250 a 300 perfilhos $\mathrm{m}^{-2}$ ). Houve redução da densidade populacional de perfilhos do verão (370 perfilhos $\mathrm{m}^{-2}$ ) para o outono/inverno (335 perfilhos $\left.\mathrm{m}^{-2}\right)$. 
Tabela 26. Densidade populacional de perfilhos (perfilhos $\mathrm{m}^{-2}$ ) em pastos de capimMombaça submetidos a regimes de pastejo intermitente durante a rebrotação no outono/inverno

\begin{tabular}{|c|c|c|c|}
\hline \multirow[b]{2}{*}{ Resíduo $(\mathrm{cm})$} & \multicolumn{3}{|c|}{ Interceptação luminosa (\%) } \\
\hline & 95 & 100 & Média \\
\hline \multirow{3}{*}{30} & & ós-pastejc & \\
\hline & $320 \mathrm{Aa}$ & $250 \mathrm{Bb}$ & $285 \mathrm{~b}$ \\
\hline & $(33,0)$ & $(33,0)$ & $(23,3)$ \\
\hline \multirow[t]{2}{*}{50} & $390 \mathrm{Aa}$ & $320 \mathrm{Aa}$ & $355 \mathrm{a}$ \\
\hline & $(33,0)$ & $(33,0)$ & $(23,3)$ \\
\hline \multirow[t]{3}{*}{ Média } & $355 \mathrm{~A}$ & $285 \mathrm{~B}$ & $320 \mathrm{~B}$ \\
\hline & $(23,3)$ & $(23,3)$ & $(16,5)$ \\
\hline & \multicolumn{3}{|c|}{ Fase intermediária } \\
\hline \multirow[t]{2}{*}{30} & $390 \mathrm{Aa}$ & $300 \mathrm{Ab}$ & $345 \mathrm{a}$ \\
\hline & $(47,5)$ & $(47,5)$ & $(33,6)$ \\
\hline \multirow[t]{2}{*}{50} & 360 Аa & $370 \mathrm{Aa}$ & 365 a \\
\hline & $(47,5)$ & $(47,5)$ & $(33,6)$ \\
\hline \multirow[t]{3}{*}{ Média } & $385 \mathrm{~A}$ & $335 \mathrm{~B}$ & $355 \mathrm{~A}^{\prime}$ \\
\hline & $(19,8)$ & $(19,8)$ & $(14,0)$ \\
\hline & & Pré-pastejo & \\
\hline \multirow[t]{2}{*}{30} & $350 \mathrm{Aa}$ & $270 \mathrm{Ab}$ & $310 \mathrm{~b}$ \\
\hline & $(56,9)$ & $(56,9)$ & $(40,2)$ \\
\hline \multirow[t]{2}{*}{50} & $320 \mathrm{Aa}$ & $380 \mathrm{Aa}$ & $350 \mathrm{a}$ \\
\hline & $(56,9)$ & $(56,9)$ & $(40,2)$ \\
\hline \multirow[t]{2}{*}{ Média } & $335 \mathrm{~A}$ & $325 \mathrm{~A}$ & $330 \mathrm{~B}^{\prime}$ \\
\hline & $(40,2)$ & $(40,2)$ & $(12,7)$ \\
\hline \multirow[t]{2}{*}{ Média da Época } & & & $335 \mathrm{~b}$ \\
\hline & & & $(21,0)$ \\
\hline
\end{tabular}

Números entre parênteses correspondem ao erro padrão da média.

Médias na mesma coluna seguidas de mesma letra minúscula não diferem entre si $(P>0,10)$.

Médias na mesma linha seguidas de mesma letra maiúscula não diferem entre si $(P>0,10)$.

Médias de fases de rebrotação seguidas de letras maiúsculas acrescidas de (") não diferem entre si $(\mathrm{P}>0,10)$.

Médias de épocas do ano seguidas de letras minúsculas acrescidas de ( ' ) nas Tabelas 25, 26 e 27 não diferem entre si $(\mathrm{P}>0,10)$.

$\mathrm{Na}$ primavera, o tratamento 30/100 apresentou a menor densidade populacional de perfilhos na condição de pós-pastejo (250 perfilhos $\mathrm{m}^{2}$ ) (Tabela 27). $\mathrm{O}$ tratamento 30/95 apresentava, na mesma condição, a maior densidade populacional (350 perfilhos $\mathrm{m}^{2}$ ). Durante a fase intermediária de rebrotação, o mesmo padrão de comportamento foi mantido, porém com valores mais elevados. Na condição de prépastejo, a consistência observada entre os tratamentos de $50 \mathrm{~cm}$ de resíduo $(95$ x 100\% 
de IL), existente na fase inicial e intermediária de rebrotação, desapareceu e o tratamento 50/95 apresentou menor densidade populacional de perfilhos que 50/100. O tratamento 30/95 manteve o maior número de perfilhos por área que os demais tratamentos.

Tabela 27. Densidade populacional de perfilhos (perfilhos $\mathrm{m}^{-2}$ ) em pastos de capimMombaça submetidos a regimes de pastejo intermitente durante a rebrotação na primavera

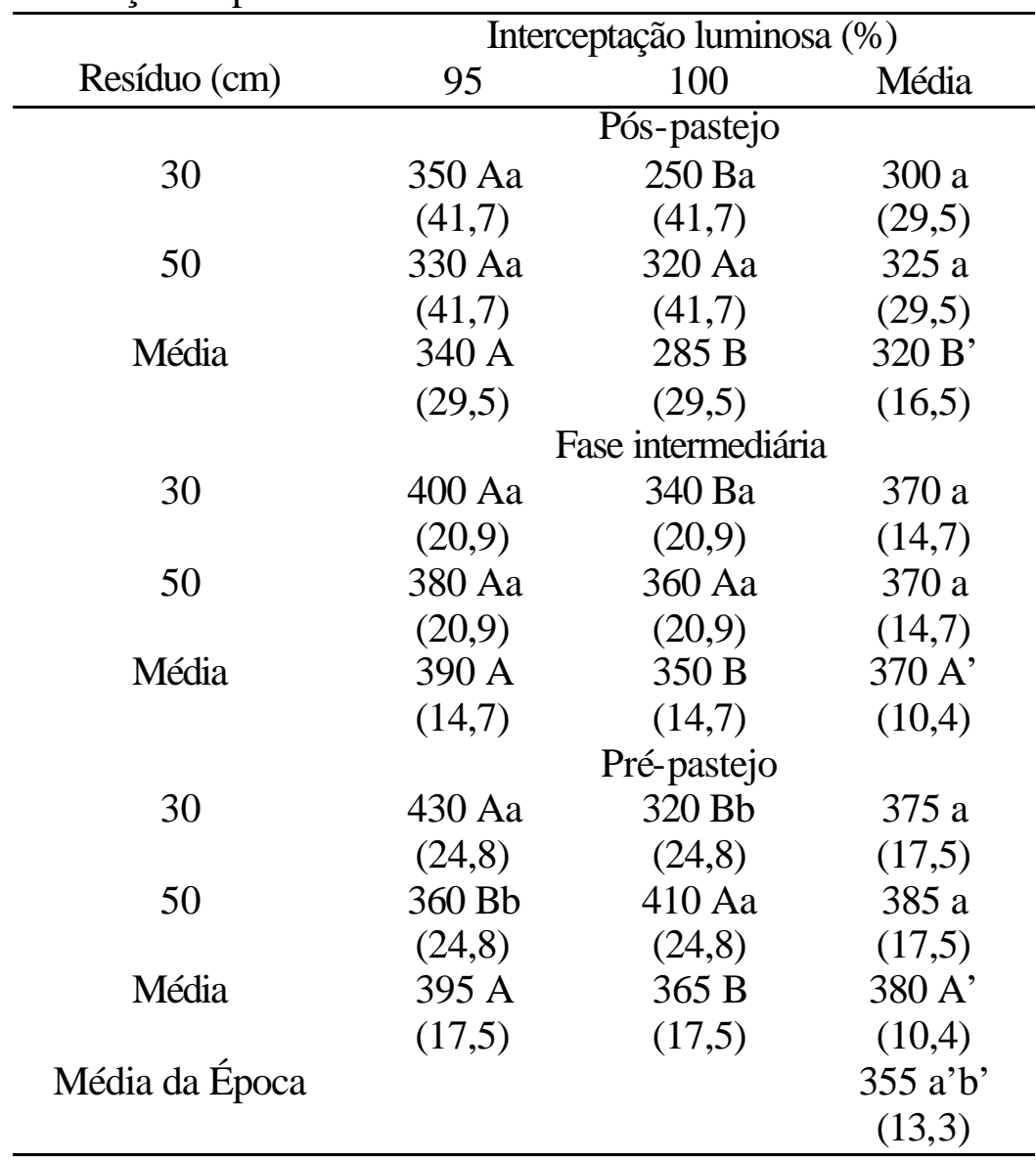

Números entre parênteses correspondem ao erro padrão da média.

Médias na mesma coluna seguidas de mesma letra minúscula não diferem entre si $(\mathrm{P}>0,10)$.

Médias na mesma linha seguidas de mesma letra maiúscula não diferem entre si $(P>0,10)$.

Médias de fases de rebrotação seguidas de letras maiúsculas acrescidas de ( ' ) não diferem entre si $(\mathrm{P}>0,10)$.

Médias de épocas do ano seguidas de letras minúsculas acrescidas de ( ') nas Tabelas 25, 26 e 27 não diferem entre si $(\mathrm{P}>0,10)$.

O comportamento geral da densidade populacional de perfilhos dos tratamentos estudados ao longo do ano pode ser visualizado na Figura 19. Observa-se 
um comportamento crescente e positivo para os tratamentos de $95 \%$ de IL durante o verão. Durante o outono/inverno, houve uma queda acentuada no número de perfilhos, particularmente no tratamento 50/95. Na primavera, o comportamento linear e positivo somente foi observado para o tratamento 30/95.

Os tratamentos de $100 \%$ de IL mostraram um comportamento de aumento no número de perfilhos seguido por uma estabilização ou redução na fase final de rebrotação no verão e outono/inverno (Figura 19). Na primavera, somente o tratamento 30/100 apresentou esse comportamento. O tratamento com 50/100 apresentou aumento linear até o final do processo de rebrotação.

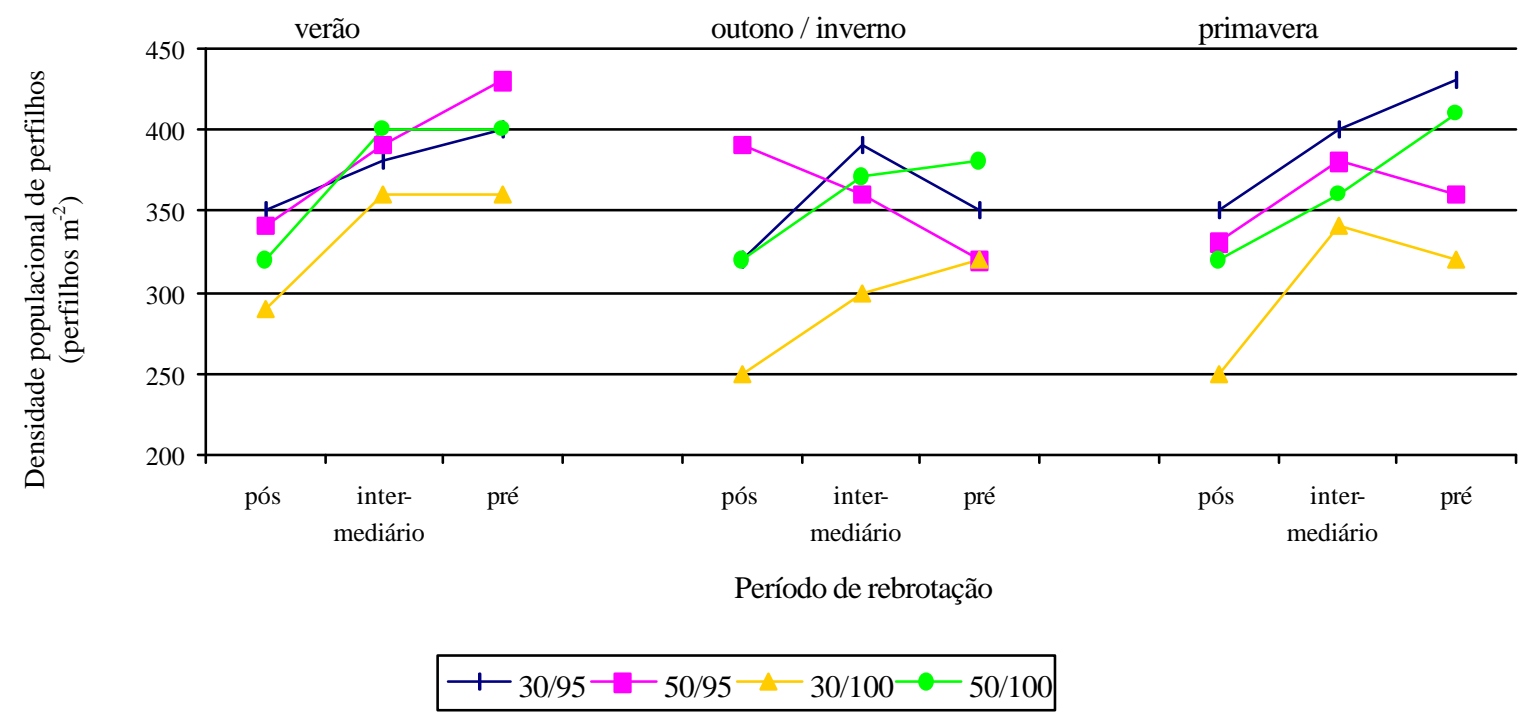

Figura 19- Densidade populacional de perfilhos nas combinações de interceptação luminosa e intensidade de pastejo durante o período de rebrotação nas épocas do ano

\subsubsection{Massa dos perfilhos}

Houve efeito de resíduo ( $\mathrm{P}=0,0985)$, interceptação luminosa $(\mathrm{P}<0,0001)$ e fase de rebrotação $(\mathrm{P}<0,0001)$, além das interações resíduo $\mathrm{x}$ época do ano $(\mathrm{P}=0,0321)$, 
resíduo x fase de rebrotação $(\mathrm{P}=0,0088)$ e interceptação luminosa $\mathrm{x}$ fase de rebrotação $(\mathrm{P}=0,0048)$.

Os tratamentos de $95 \%$ de IL produziram perfilhos mais leves $\left(2,5 \mathrm{~g}\right.$ perfilho $\left.{ }^{-1}\right)$ na condição de pré-pastejo que os tratamentos de $100 \%$ de IL (3,6 $\mathrm{g}_{\text {perfilho }}{ }^{-1}$ ) (Tabela 28). A menor massa por perfilho foi verificada para o tratamento $30 / 95\left(2,4 \mathrm{~g}\right.$ perfilho $\left.{ }^{-1}\right)$, tratamento esse caracterizado pela maior frequiência e intensidade de pastejo utilizada no experimento. A maior massa por perfilho correspondeu ao tratamento 30/100 (3,8 g perfilho $^{-1}$ )

Tabela 28. Massa por perfilho (g) do capim-Mombaça submetido a regimes de pastejo intermitente na condição de pré-pastejo

\begin{tabular}{cccc}
\hline Resíduo (cm) & \multicolumn{3}{c}{ Interceptação luminosa (\%) } \\
& 95 & 100 & Média \\
\hline 30 & 2,4 & 3,8 & 3,1 \\
& $(0,17)$ & $(0,17)$ & $(0,12)$ \\
50 & 2,7 & 3,4 & 3,0 \\
& $(0,17)$ & $(0,17)$ & $(0,12)$ \\
Média & $2,5 \mathrm{~B}$ & $3,6 \mathrm{~A}$ & 3,0 \\
& $(0,12)$ & $(0,12)$ & \\
\hline
\end{tabular}

Números entre parênteses correspondem ao erro padrão da média.

Médias na mesma coluna seguidas de mesma letra minúscula não diferem entre si $(\mathrm{P}>0,10)$.

Médias na mesma linha seguidas de mesma letra maiúscula não diferem entre si $(P>0,10)$.

A massa dos perfilhos para os tratamentos de 30 e $50 \mathrm{~cm}$ de resíduo foi muito semelhante durante o verão e o outono/inverno. Na primavera, houve um aumento na massa dos perfilhos para os tratamentos de $30 \mathrm{~cm}\left(3,4 \mathrm{~g}_{\text {perfilho }}{ }^{-1}\right)$ e uma redução para os tratamentos de $50 \mathrm{~cm}$ (2,8 g perfilho $\left.^{-1}\right)$ (Tabela 29). 
Tabela 29. Massa por perfilho (g) na condição de pré-pastejo do capim-Mombaça para os tratamentos de 30 e $50 \mathrm{~cm}$ de resíduo durante as épocas do ano

\begin{tabular}{ccccc}
\hline $\begin{array}{c}\text { Resíduo } \\
(\mathrm{cm})\end{array}$ & Verão & $\begin{array}{c}\text { Épocas do ano } \\
\text { Outono/Inverno }\end{array}$ & Primavera & Média \\
\hline 30 & $2,9 \mathrm{Ba}$ & $3,0 \mathrm{Ba}$ & $3,4 \mathrm{Aa}$ & 3,1 \\
& $(0,13)$ & $(0,20)$ & $(0,17)$ & $(0,17)$ \\
50 & $3,1 \mathrm{ABa}$ & $3,2 \mathrm{Aa}$ & $2,8 \mathrm{Bb}$ & 3,0 \\
& $(0,13)$ & $(0,20)$ & $(0,17)$ & $(0,17)$ \\
Média & 3,0 & 3,1 & 3,1 & 3,1 \\
& $(0,17)$ & $(0,18)$ & $(0,16)$ & \\
\hline
\end{tabular}

Números entre parênteses correspondem ao erro padrão da média.

Médias na mesma coluna seguidas de mesma letra minúscula não diferem entre si $(P>0,10)$.

Médias na mesma linha seguidas de mesma letra maiúscula não diferem entre si $(\mathrm{P}>0,10)$.

Durante a rebrotação os perfilhos tiveram aumento de massa, sendo que nos tratamentos de $30 \mathrm{~cm}$ de resíduo esse aumento foi maior $(+1,3 \mathrm{~g})$ que aquele dos tratamentos de $50 \mathrm{~cm}$ de resíduo (+0,7 g) (Tabela 30). Para ambos os resíduos estudados os perfilhos atingiram o ponto de pastejo com a mesma massa.

Tabela 30. Massa por perfilho (g) para os tratamentos de 30 e $50 \mathrm{~cm}$ de resíduo no capim-Mombaça durante a rebrotação

\begin{tabular}{cccc}
\hline $\begin{array}{c}\text { Resíduo } \\
(\mathrm{cm})\end{array}$ & \multicolumn{3}{c}{ Período de rebrotação } \\
& Pós-pastejo & Intermediário & Pré-pastejo \\
\hline 30 & $1,8 \mathrm{Ca}$ & $2,3 \mathrm{Ba}$ & $3,1 \mathrm{Aa}$ \\
& $(0,23)$ & $(0,12)$ & $(0,19)$ \\
50 & $2,3 \mathrm{Ba}$ & $2,4 \mathrm{Ba}$ & $3,0 \mathrm{Aa}$ \\
& $(0,23)$ & $(0,12)$ & $(0,19)$ \\
Média & $2,0 \mathrm{C}$ & $2,3 \mathrm{~B}$ & $3,1 \mathrm{~A}$ \\
& $(0,16)$ & $(0,09)$ & $(0,14)$ \\
\hline
\end{tabular}

Números entre parênteses correspondem ao erro padrão da média.

Médias na mesma coluna seguidas de mesma letra minúscula não diferem entre si $(\mathrm{P}>0,10)$.

Médias na mesma linha seguidas de mesma letra maiúscula não diferem entre si $(\mathrm{P}>0,10)$.

Com relação ao efeito de interceptação luminosa, os perfilhos dos tratamentos de $100 \%$ de $\mathrm{IL}$ apresentaram um aumento de massa $(+1,4 \mathrm{~g})$ mais pronunciado que aqueles dos tratamentos de $95 \%$ de $\mathrm{IL}(0,7 \mathrm{~g})$, o que resultou em perfilhos maiores ao final do período de rebrotação (Tabela 31). 
Tabela 31. Massa por perfilho (g) para os tratamentos com 95 e $100 \%$ de interceptação luminosa de capim-Mombaça durante a rebrotação

\begin{tabular}{cccc}
\hline Interceptação & \multicolumn{3}{c}{ Período de rebrotação } \\
luminosa (\%) & Pós-pastejo & Intermediário & Pré-pastejo \\
\hline 95 & $1,8 \mathrm{Ca}$ & $2,1 \mathrm{Bb}$ & $2,5 \mathrm{Ab}$ \\
& $(0,23)$ & $(0,12)$ & $(0,19)$ \\
100 & $2,2 \mathrm{Ca}$ & $2,6 \mathrm{Ba}$ & $3,6 \mathrm{Aa}$ \\
& $(0,23)$ & $(0,12)$ & $(0,19)$ \\
Média & $2,0 \mathrm{C}$ & $2,3 \mathrm{~B}$ & $3,1 \mathrm{~A}$ \\
& $(0,16)$ & $(0,09)$ & $(0,14)$ \\
\hline
\end{tabular}

Números entre parênteses correspondem ao erro padrão da média.

Médias na mesma coluna seguidas de mesma letra minúscula não diferem entre si $(\mathrm{P}>0,10)$.

Médias na mesma linha seguidas de mesma letra maiúscula não diferem entre si $(\mathrm{P}>0,10)$.

Os valores de densidade populacional de perfilhos e massa por perfilho durante o processo de rebrotação ao longo do ano foram relacionados nas Figuras 20 (30/95), 21 (50/95), 22 (30/100) e $23(50 / 100)$.

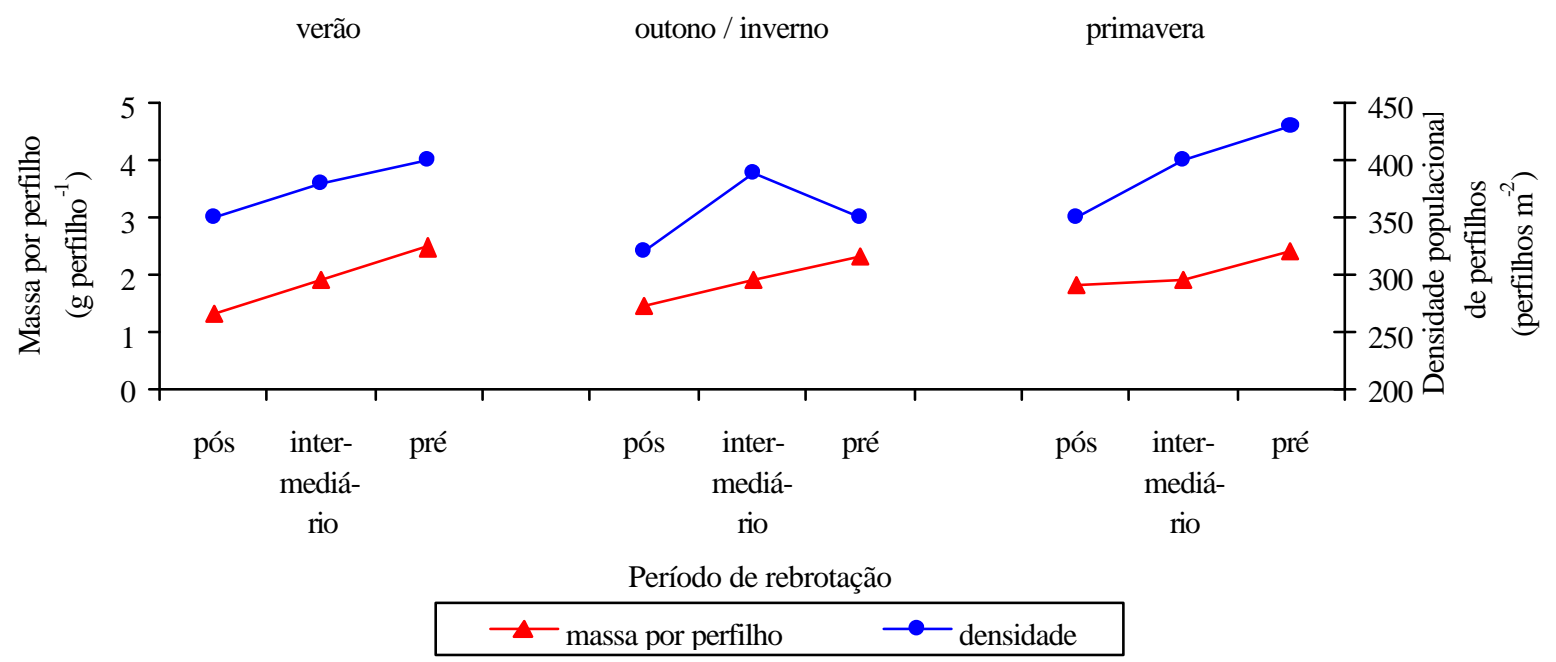

Figura 20- Densidade populacional de perfilhos e massa por perfilho no tratamento de $95 \%$ de interceptação luminosa e $30 \mathrm{~cm}$ de resíduo durante a rebrotação nas épocas do ano 


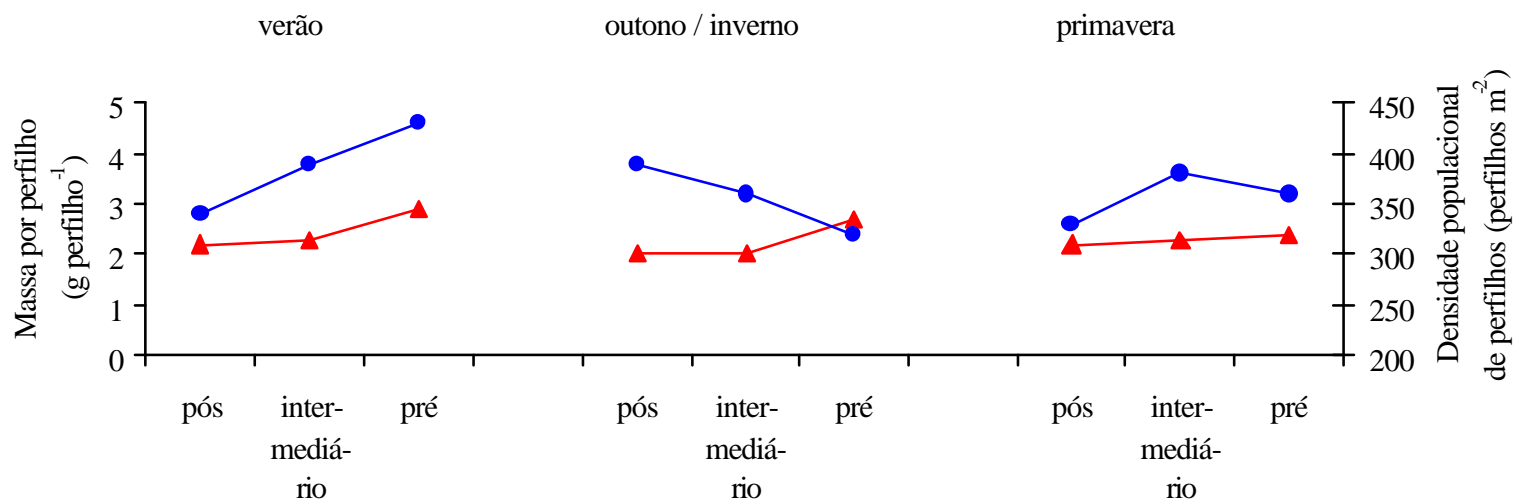

Período de rebrotação

$\hookrightarrow$ massa por perfilho $\quad \longrightarrow$ densidade

Figura 21- Densidade populacional de perfilhos e massa por perfilho no tratamento de 95\% de interceptação luminosa e $50 \mathrm{~cm}$ de resíduo durante a rebrotação nas épocas do ano

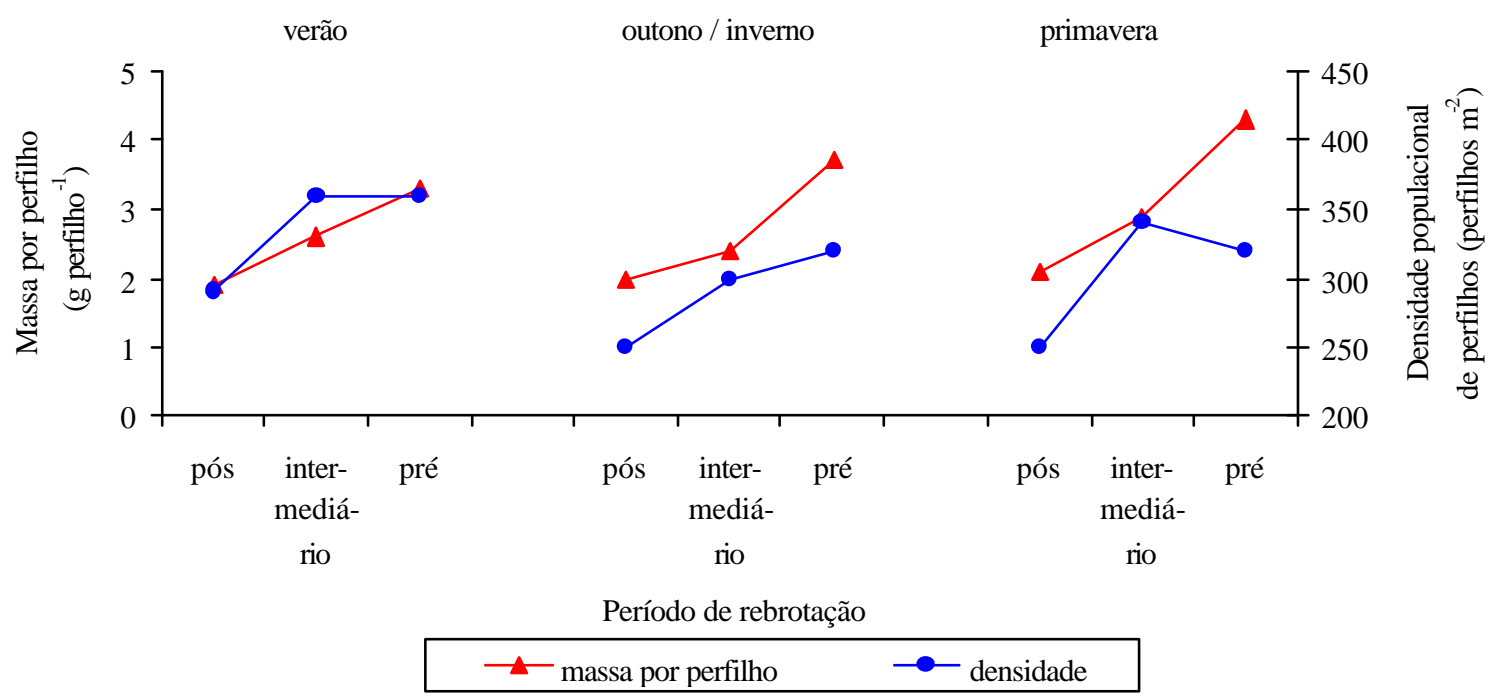

Figura 22- Densidade populacional de perfilhos e massa por perfilho no tratamento de $100 \%$ de interceptação luminosa e $30 \mathrm{~cm}$ de resíduo durante a rebrotação nas épocas do ano 


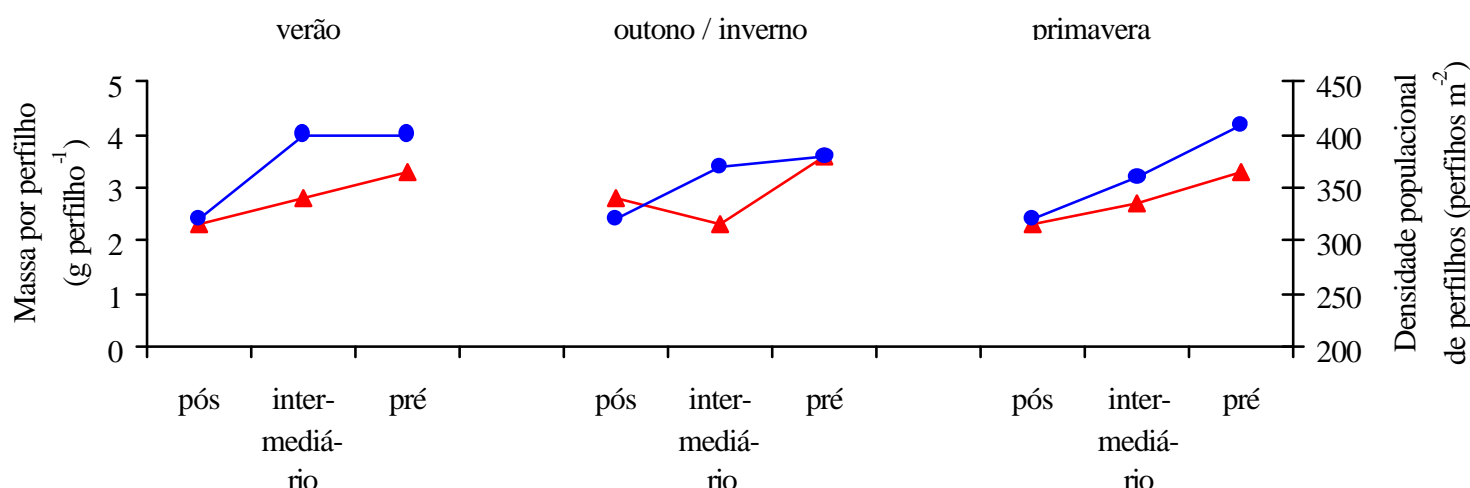

Período de rebrotação

$\multimap$ massa por perfilho $\quad \longrightarrow$ densidade

Figura 23- Densidade populacional de perfilhos e massa por perfilho no tratamento de $100 \%$ de interceptação luminosa e $50 \mathrm{~cm}$ de resíduo durante a rebrotação nas épocas do ano

O tratamento 30/95 apresentou aumento consistente na massa por perfilho durante a rebrotação em todas as estações do ano, enquanto que a densidade populacional apresentou comportamento semelhante somente na época das águas (primavera e verão). No outono/inverno, a densidade populacional atingiu um ponto máximo na metade da rebrotação (Figura 20), quando diminuiu até a ocorrência do pastejo. O tratamento 50/95 apresentou um aumento mais lento da massa por perfilho no início da rebrotação, havendo aceleração a partir da segunda metade do processo. Já a densidade populacional apresentou comportamento variável durante o ano, aumentando durante o verão, decrescendo durante o outono/inverno e, na primavera, aumentando até a metade do período de rebrotação, diminuindo até o pré-pastejo (Figura 21).

A densidade populacional de perfilhos no tratamento 30/100 apresentou comportamento mais estável ao longo do ano. No início da rebrotação houve um acentuado aumento até a metade do período de rebrotação, estabilizando-se ou 
diminuindo depois desse período. A massa por perfilho apresentou aumento consistente durante o período de rebrotação no decorrer de todas as estações do ano (Figura 22). Já o tratamento 50/100 apresentou aumento da densidade populacional de perfilhos no início e estabilização a partir do período intermediário de rebrotação durante o verão e outono/inverno, aumentando continuamente durante a primavera. A massa por perfilho aumentou consistentemente durante a rebrotação em todas as épocas do ano (Figura 23).

\subsection{Dinâmica do acúmulo de forragem}

O estudo da dinâmica do acúmulo de forragem teve como objetivo principal descrever o processo de produção de massa seca pelo pasto (crescimento e senescência de folhas e hastes) durante o período de rebrotação. Em função do intervalo variável entre pastejos para os tratamentos e épocas do ano, o período de rebrotação foi, então, dividido em três subperíodos (item 3.3). A fase inicial correspondeu ao primeiro terço do período de rebrotação e teve início após cada pastejo. A fase intermediária correspondeu ao terço intermediário do período de rebrotação e a fase final correspondeu ao terço final processo de rebrotação, encerrado com um novo pastejo. A partir da divisão realizada dentro de cada período de rebrotação, foram calculadas as médias para cada época do ano de forma que os valores relatados nas tabelas a seguir correspondem às médias dos pastejos. Conforme já mencionado, o número de pastejos para cada tratamento variou (Tabela 3 e Figura 11) e será considerado individualmente de forma oportuna. 


\subsubsection{Lâminas foliares}

\subsubsection{Crescimento (Expansão foliar)}

Houve efeito de fase de rebrotação $(\mathrm{P}=0,0018)$ e época do ano $(\mathrm{P}=0,0001)$, além das interações interceptação luminosa $x$ fase de rebrotação $(\mathrm{P}=0,0574)$ e época do ano $\mathrm{x}$ fase de rebrotação $(\mathrm{P}=0,0268)$.

As taxas de expansão foliar foram maiores no primeiro terço do processo de rebrotação e decresceram até o final deste período (4,5 para 3,3 cm perfilho- ${ }^{-1}$ dia $^{-1}$ ) (Tabela 32). Os tratamentos de 95 e 100\% de IL não diferiram quanto à taxa de expansão foliar durante a primeira fase de rebrotação $\left(4,26\right.$ e $4,82 \mathrm{~cm}$ perfilho- ${ }^{-1}$ dia $^{-1}$, respectivamente). No entanto, da segunda fase em diante, as taxas foram maiores para os tratamentos de 95\% de IL. A redução na taxa de expansão de folhas dos tratamentos de $95 \%$ de IL ao longo do período de rebrotação foi de 4,26 para 3,68 cm perfilho ${ }^{-1} \mathrm{dia}^{-1}$, não havendo diferença $(\mathrm{P}>0,10)$ entre os valores do início ou final do período de rebrotação. Nos tratamentos de $100 \%$ de IL a redução correspondente foi de 4,82 para $3,27 \mathrm{~cm}$ perfilho ${ }^{-1} \mathrm{dia}^{-1}$, sendo esta diferença significativa $(\mathrm{P} \leq 0,10)$ em todas as fases de rebrotação.

Tabela 32. Taxa de expansão de lâminas foliares ( $\mathrm{cm}$ perfilho ${ }^{-1} \mathrm{dia}^{-1}$ ) de capimMombaça para os tratamentos de 95 e $100 \%$ de IL durante a rebrotação

\begin{tabular}{cccc}
\hline Interceptação & \multicolumn{3}{c}{ Período de rebrotação } \\
luminosa $(\%)$ & Inicial & Intermediário & Final \\
\hline 95 & $4,26 \mathrm{Aa}$ & $3,99 \mathrm{Aa}$ & $3,68 \mathrm{Aa}^{*}$ \\
& $(0,579)$ & $(0,486)$ & $(0,352)$ \\
100 & $4,82 \mathrm{Aa}$ & $3,75 \mathrm{Ba}$ & $2,87 \mathrm{Cb}^{*}$ \\
& $(0,579)$ & $(0,486)$ & $(0,352)$ \\
Média & $4,54 \mathrm{~A}$ & $3,87 \mathrm{~B}$ & $3,27 \mathrm{C}$ \\
& $(0,409)$ & $(0,255)$ & $(0,361)$ \\
\hline
\end{tabular}

Números entre parênteses correspondem ao erro padrão da média.

Médias na mesma coluna seguidas de mesma letra minúscula não diferem entre si $(\mathrm{P}>0,10)$.

Médias na mesma linha seguidas de mesma letra maiúscula nãodiferem entre si $(\mathrm{P}>0,10)$.

*Diferem entre si $(\mathrm{P}=0,1108)$

A redução nas taxas de expansão de folhas ao longo do processo de rebrotação ocorreu durante todas as épocas do ano (Tabela 33). No verão, essa redução foi de 5,7 
para 3,9 $\mathrm{cm}$ folhas perfilho ${ }^{-1} \mathrm{dia}^{-1}$, no outono/inverno de 2,4 para $1,9 \mathrm{~cm}$ folhas perfilho ${ }^{-1}$ $\mathrm{dia}^{-1}$ e na primavera de 5,5 para 4,0 $\mathrm{cm}$ folhas perfilho ${ }^{-1} \mathrm{dia}^{-1}$. Não houve diferença entre as taxas de expansão de folhas do verão e da primavera $\left(4,8 \mathrm{~cm}\right.$ de folhas perfilho $\left.{ }^{-1} \mathrm{dia}^{-1}\right)$ $(\mathrm{P}>0,10)$, mas houve redução acentuada durante a época de outono/inverno.

Tabela 33. Taxa de expansão de lâminas foliares ( $\mathrm{cm}$ perfilho ${ }^{-1} \mathrm{dia}^{-1}$ ) de capimMombaça durante a rebrotação de acordo com as épocas do ano

\begin{tabular}{ccccc}
\hline Época do ano & \multicolumn{4}{c}{ Período de rebrotação } \\
& Inicial & Intermediário & Final & Média \\
\hline Verão & $5,69 \mathrm{~A}$ & $4,92 \mathrm{~B}$ & $3,89 \mathrm{C}$ & $4,84 \mathrm{a}$ \\
& $(0,462)$ & $(0,486)$ & $(0,427)$ & $(0,437)$ \\
Outono/Inverno & $2,39 \mathrm{~A}$ & $1,66 \mathrm{~B}$ & $1,89 \mathrm{AB}$ & $1,98 \mathrm{~b}$ \\
& $(0,547)$ & $(0,498)$ & $(0,300)$ & $(0,427)$ \\
Primavera & $5,53 \mathrm{~A}$ & $5,03 \mathrm{AB}$ & $4,04 \mathrm{~B}$ & $4,88 \mathrm{a}$ \\
& $(0,547)$ & $(0,346)$ & $(0,275)$ & $(0,350)$ \\
Média & $4,54 \mathrm{~A}$ & $3,87 \mathrm{~B}$ & $3,27 \mathrm{C}$ & 3,90 \\
& $(0,409)$ & $(0,255)$ & $(0,361)$ & \\
\hline
\end{tabular}

Números entre parênteses correspondem ao erro padrão da média.

Médias na mesma coluna seguidas de mesma letra minúscula não diferem entre si $(\mathrm{P}>0,10)$.

Médias na mesma linha seguidas de mesma letra maiúscula não diferem entre si $(P>0,10)$.

Os valores de variação em comprimento das lâminas foliares foram transformados em valores de variação em massa, gerando os valores de taxa de expansão de folhas em mg perfilho ${ }^{-1}$ dia $^{-1}$ (Tabela 34). Houve efeito de época do ano ( $\left.\mathrm{P}=0,0021\right)$, fase de rebrotação $(\mathrm{P}=0,0022)$ e da interação interceptação luminosa $\mathrm{x}$ fase de rebrotação $\mathrm{x}$ época do ano $(\mathrm{P}=0,0608)$. Neste caso, apesar de terem sido registradas diferenças numéricas entre as taxas de expansão de folhas para os tratamentos de 95 e $100 \%$ de IL, elas não foram significativas $(\mathrm{P}>0,10)$. A redução nas taxas de expansão durante a rebrotação ocorreu principalmente para os tratamentos de $100 \%$ de IL. As taxas variaram de 20,8 a 42,7 mg perfilho ${ }^{-1}$ dia $^{-1}$ na primavera e verão e, de 11,1 a $22,1 \mathrm{mg}$ perfilho ${ }^{-1} \mathrm{dia}^{-1}$ no outono/inverno. 
Tabela 34. Taxa de expansão de folhas (mg perfilho- ${ }^{-1}$ dia $^{-1}$ ) de capim-Mombaça para os tratamentos com 95 e $100 \%$ de interceptação luminosa durante a rebrotação de acordo com as épocas do ano

\begin{tabular}{|c|c|c|c|c|}
\hline \multirow{2}{*}{$\begin{array}{l}\text { Interceptação } \\
\text { luminosa (\%) }\end{array}$} & \multicolumn{3}{|c|}{ Período de rebrotação } & \multirow[b]{2}{*}{ Média de época } \\
\hline & Inicial & Intermediário & Final & \\
\hline \multicolumn{5}{|c|}{ Verão } \\
\hline 95 & $\begin{array}{c}\text { 42,7Aa } \\
(4,25)\end{array}$ & $\begin{array}{c}37,0 \mathrm{Ba} \\
(5,43)\end{array}$ & $\begin{array}{c}31,4 \mathrm{Ca} \\
(4,25)\end{array}$ & \\
\hline 100 & $\begin{array}{c}36,2 \mathrm{Aa} \\
(4,25)\end{array}$ & $\begin{array}{c}32,7 \mathrm{Aa} \\
(5,43)\end{array}$ & $\begin{array}{c}23,3 \mathrm{Ba} \\
(4,25)\end{array}$ & \\
\hline Média & $\begin{array}{c}39,4 \mathrm{~A} \\
(3,01)\end{array}$ & $\begin{array}{l}34,8 \mathrm{~B} \\
(3,84)\end{array}$ & $\begin{array}{l}27,3 \mathrm{C} \\
(3,01)\end{array}$ & $\begin{array}{r}33,9 \mathrm{~A}^{\prime} \\
(3,15)\end{array}$ \\
\hline \multicolumn{5}{|c|}{ Outono/Inverno } \\
\hline 95 & $\begin{array}{c}15,3 \mathrm{Ab} \\
(3,46)\end{array}$ & $\begin{array}{c}15,1 \mathrm{Aa} \\
(3,94)\end{array}$ & $\begin{array}{c}14,3 \mathrm{Aa} \\
(2,86)\end{array}$ & \\
\hline 100 & $\begin{array}{c}22,1 \mathrm{Aa} \\
(3,46)\end{array}$ & $\begin{array}{c}11,1 \mathrm{Ba} \\
(3,94)\end{array}$ & $\begin{array}{c}12,4 \mathrm{Ba} \\
(2,86)\end{array}$ & \\
\hline Média & $\begin{array}{l}18,7 \mathrm{~A} \\
(2,45)\end{array}$ & $\begin{array}{l}13,1 \mathrm{~B} \\
(2,78)\end{array}$ & $\begin{array}{l}13,3 \mathrm{~B} \\
(2,02)\end{array}$ & $\begin{array}{c}15,0 \mathrm{~B} \\
(3,15)\end{array}$ \\
\hline \multicolumn{5}{|c|}{ Primavera } \\
\hline 95 & $\begin{array}{c}33,7 \mathrm{Aa} \\
(6,17)\end{array}$ & $\begin{array}{c}38,3 \mathrm{Aa} \\
(8,17)\end{array}$ & $\begin{array}{c}33,6 \mathrm{Aa} \\
(6,31)\end{array}$ & \\
\hline 100 & $\begin{array}{c}36,9 \mathrm{Aa} \\
(6,17)\end{array}$ & $\begin{array}{c}30,0 \mathrm{Aa} \\
(8,17)\end{array}$ & $\begin{array}{c}20,8 \mathrm{Ba} \\
(6,31)\end{array}$ & \\
\hline Média & $\begin{array}{c}35,3 \mathrm{~A} \\
(4,36)\end{array}$ & $\begin{array}{c}34,1 \mathrm{~A} \\
(5,78)\end{array}$ & $\begin{array}{l}27,2 \text { B } \\
(4,46)\end{array}$ & $\begin{array}{c}32,2 A^{\prime} \\
(3,15)\end{array}$ \\
\hline Média de Fases & $\begin{array}{l}31,1 \mathrm{~A} \\
(1,81)\end{array}$ & $\begin{array}{l}27,3 \mathrm{~B} \\
(2,52)\end{array}$ & $\begin{array}{l}22,6 \mathrm{C} \\
(1,99)\end{array}$ & \\
\hline
\end{tabular}

Números entre parênteses correspondem ao erro padrão da média.

Médias na mesma coluna seguidas de mesma letra minúscula não diferem entre si $(\mathrm{P}>0,10)$.

Médias na mesma linha seguidas de mesma letra maiúscula não diferem entre si $(\mathrm{P}>0,10)$.

Médias de épocas do ano seguidas de letras maiúsculas acrescidas de ( ') não diferem entre si ( $\mathrm{P}>0,10)$.

Com relação ao número de folhas em expansão por perfilho, houve efeito de época do ano $(\mathrm{P}<0,0001)$ e da interação fase de rebrotação x época do ano $(\mathrm{P}=0,0038)$. O número de folhas em expansão por perfilho foi sendo reduzido gradativamente a cada fase de rebrotação (Tabela 35). Essa redução foi de 1,30 para 0,93 folha perfilho ${ }^{-1}$ no verão, de 0,87 para 0,69 folha perfilho-1 no outono/inverno e de 1,14 para 1,07 folhas perfilho $^{-1}$ na primavera do início para o final do período de rebrotação, respectivamente. 
Tabela 35. Número médio de folhas em expansão por perfilho no capim-Mombaça durante a rebrotação nas épocas do ano

\begin{tabular}{cccc}
\hline Época do ano & \multicolumn{3}{c}{ Período de rebrotação } \\
& Inicial & Intermediário & Final \\
\hline Verão & $1,30 \mathrm{Aa}$ & $1,17 \mathrm{Ba}$ & $0,93 \mathrm{Ca}$ \\
& $(0,088)$ & $(0,088)$ & $(0,088)$ \\
Outono/Inverno & $0,87 \mathrm{Ac}$ & $0,68 \mathrm{Bb}$ & $0,69 \mathrm{Bb}$ \\
& $(0,092)$ & $(0,092)$ & $(0,092)$ \\
Primavera & $1,14 \mathrm{Ab}$ & $1,14 \mathrm{Aa}$ & $1,07 \mathrm{Aa}$ \\
& $(0,088)$ & $(0,088)$ & $(0,08)$ \\
Média & $1,10 \mathrm{~A}$ & $1,00 \mathrm{~B}$ & $0,89 \mathrm{C}$ \\
& $(0,062)$ & $(0,062)$ & $(0,062)$ \\
\hline
\end{tabular}

Números entre parênteses correspondem ao erro padrão da média.

Médias na mesma coluna seguidas de mesma letra minúscula não diferem entre si $(\mathrm{P}>0,10)$.

Médias na mesma linha seguidas de mesma letra maiúscula não diferem entre si $(\mathrm{P}>0,10)$.

A taxa de aparecimento de folhas sofreu influência apenas de época do ano ( $\mathrm{P}<0,0001)$. No outono/inverno foram registradas as menores taxas de aparecimento (0,020 folha perfilho $\left.{ }^{-1} \mathrm{dia}^{-1}\right)$, aumentando com a entrada da primavera $(0,055$ folha perfilho $\left.{ }^{-1} \mathrm{dia}^{-1}\right)$ e mantendo a tendência de aumento com a entrada do verão $(0,070$ folha perfilho ${ }^{-1}$ dia $\left.^{-1}\right)$, seguindo um padrão estacional. Não houve diferença $(\mathrm{P}>0,10)$ entre os tratamentos de 95 e $100 \%$ de IL.

O filocrono dos tratamentos de $95 \%$ de IL foi 6 dias menor que aquele dos tratamentos de $100 \%$ de IL, diferença essa não significativa $(\mathrm{P}>0,10)$ (Tabela 36). Houve apenas efeito de época do ano $(\mathrm{P}<0,0001)$. O maior filocrono foi registrado durante o outono/inverno (51 dias). Na primavera e no verão foram necessários, respectivamente, 18 e 15 dias para o aparecimento de uma nova folha. 
Tabela 36. Filocrono (dias perfilho ${ }^{-1}$ folha $^{-1}$ ) em capim-Mombaça para os tratamentos de 95 e $100 \%$ de IL durante as épocas do ano

\begin{tabular}{ccccc}
\hline $\begin{array}{c}\text { Interceptação } \\
\text { luminosa (\%) }\end{array}$ & Verão & $\begin{array}{c}\text { Épocas do ano } \\
\text { Outono/Inverno }\end{array}$ & Primavera & Média \\
\hline 95 & 13,3 & 44,5 & 16,5 & 24,8 \\
& $(1,52)$ & $(9,82)$ & $(1,33)$ & $(3,22)$ \\
100 & 15,8 & 57,4 & 19,2 & 30,8 \\
& $(1,52)$ & $(9,82)$ & $(1,33)$ & $(3,22)$ \\
Média & $14,6 \mathrm{C}$ & $51,0 \mathrm{~A}$ & $17,9 \mathrm{~B}$ & 27,8 \\
& $(1,07)$ & $(6,94)$ & $(0,9)$ & \\
\hline
\end{tabular}

Números entre parênteses correspondem ao erro padrão da média.

Médias na mesma linha seguidas de mesma letra maiúscula não diferem entre si $(\mathrm{P}>0,10)$.

Com base nos dados de intervalos entre pastejos (duração do período de rebrotação), densidade populacional de perfilhos e taxa de expansão de folhas (mg perfilho $^{-1}$ dia $^{-1}$ ), foram calculados os valores de expansão acumulada de lâminas foliares por pastejo (Tabela 37). Houve efeito de interceptação luminosa $(\mathrm{P}=0,0798)$ e da interação interceptação luminosa x época do ano $(\mathrm{P}=0,0989)$.

Tabela 37. Expansão acumulada de lâminas foliares por pastejo $\left(\mathrm{kg} \mathrm{ha}^{-1} \mathrm{de} \mathrm{MS}\right)$ em capim-Mombaça para os tratamentos com 95 e $100 \%$ de interceptação luminosa durante a rebrotação

\begin{tabular}{ccccc}
\hline Interceptação & \multicolumn{3}{c}{ Época do ano } \\
luminosa (\%) & Verão & Outono/inverno & Primavera & Média \\
\hline 95 & $3.850 \mathrm{Aa}$ & $2.520 \mathrm{Bb}$ & $3.140 \mathrm{ABa}$ & $3.170 \mathrm{~b}$ \\
& $(523)$ & $(812)$ & $(517)$ & $(299)$ \\
100 & $4.180 \mathrm{Aa}$ & $4.490 \mathrm{Aa}$ & $4.290 \mathrm{Aa}$ & $4.220 \mathrm{a}$ \\
& $(523)$ & $(812)$ & $(517)$ & $(299)$ \\
Média & $4.020 \mathrm{~A}$ & $3.360 \mathrm{~A}$ & $3.720 \mathrm{~A}$ & 3.700 \\
& $(234)$ & $(364)$ & $(200)$ & \\
\hline
\end{tabular}

Números entre parênteses correspondem ao erro padrão da média.

Médias na mesma coluna seguidas de mesma letra minúscula não diferem entre si $(\mathrm{P}>0,10)$.

Médias na mesma linha seguidas de mesma letra maiúscula não diferem entre si $(\mathrm{P}>0,10)$.

Os tratamentos de $100 \%$ de IL apresentaram uma expansão acumulada de folhas por pastejo $33 \%$ superior àquela dos tratamentos de $95 \%$ de IL. No entanto, o número de pastejos nos tratamentos de $95 \%$ de IL foi maior $(3,1 ; 2,3 ; 2,6$ para $95 \%$ e 2,$5 ; 1,8 ; 1,4$ para $100 \%$ de IL nas épocas de verão, outono/inverno e primavera, respectivamente), de forma que a expansão acumulada de folhas no ano foi de $25.900 \mathrm{~kg}$ $\mathrm{ha}^{-1}$ de MS para $95 \%$ de IL e $24.540 \mathrm{~kg} \mathrm{ha}^{-1}$ de MS para $100 \%$ de IL. Assim, a expansão 
acumulada de folhas do tratamento de $100 \%$ de IL foi $1.360 \mathrm{~kg} \mathrm{ha}^{-1}$ menor que aquela dos tratamentos de $95 \%$ de IL.

\subsubsection{Senescência foliar}

Concomitante ao processo de expansão foliar, há o processo de senescência e morte de folhas. Este sofreu a influência de interceptação luminosa $(\mathrm{P}=0,0469)$ e fase de rebrotação $(\mathrm{P}<0,0001)$, além da interação interceptação luminosa $\mathrm{x}$ fase de rebrotação $(\mathrm{P}=0,0201)$.

As taxas de senescência no início do processo de rebrotação foram semelhantes ( 3 a $4 \mathrm{mg}$ perfilho ${ }^{-1} \mathrm{dia}^{-1}$ ), independentemente do tratamento estudado. A partir da segunda fase iniciou-se a diferenciação entre os tratamentos de 95 e 100\% de IL, com valores de 4,4 e 8,2 mg perfilho ${ }^{-1}$ dia $^{-1}$ e 9,3 e 18,2 $\mathrm{mg}$ perfilho ${ }^{-1}$ dia $^{-1}$ no meio e final do período de rebrotação para os tratamentos de 95 e $100 \%$ de IL, respectivamente. Além disso, a elevação das taxas de senescência do início para o final do período de rebrotação foi de 3,0 para $8,2 \mathrm{mg}$ perfilho ${ }^{-1}$ dia $^{-1}$ para os tratamentos de $95 \%$ de IL e de 3,9 para 18,2 mg perfilho $^{-1}$ dia $^{-1}$ para $100 \%$ de IL (Tabela 38).

Tabela 38. Taxa de senescência de lâminas foliares (mg perfilho ${ }^{-1} \mathrm{dia}^{-1}$ ) de capimMombaça para os tratamentos de 95 e 100\% de interceptação luminosa durante a rebrotação

\begin{tabular}{cccc}
\hline Interceptação & \multicolumn{3}{c}{ Período de rebrotação } \\
luminosa (\%) & Inicial & Intermediário & Final \\
\hline 95 & $3,0 \mathrm{Ba}$ & $4,4 \mathrm{ABb}$ & $8,2 \mathrm{Ab}$ \\
& $(0,89)$ & $(1,38)$ & $(3,21)$ \\
100 & $3,9 \mathrm{Ca}$ & $9,3 \mathrm{Ba}$ & $18,2 \mathrm{Aa}$ \\
& $(0,89)$ & $(1,38)$ & $(3,21)$ \\
Média & $3,5 \mathrm{C}$ & $6,8 \mathrm{~B}$ & $13,2 \mathrm{~A}$ \\
& $(0,63)$ & $(0,98)$ & $(2,27)$ \\
\hline
\end{tabular}

Números entre parênteses correspondem ao erro padrão da média.

Médias na mesma coluna seguidas de mesma letra minúscula não diferem entre si $(\mathrm{P}>0,10)$.

Médias na mesma linha seguidas de mesma letra maiúscula não diferem entre si $(P>0,10)$.

O aumento da senescência no final do processo de rebrotação afetou negativamente o número médio de folhas vivas por perfilho nessa fase (Tabela 39). 
Houve redução de aproximadamente 0,5 folha viva por perfilho do início para o final do período de rebrotação. Na primavera, essa redução foi menor (de 4,8 para 4,7 folhas vivas perfilho ${ }^{-1}$ ), enquanto que no verão o número de folhas vivas foi reduzido de 4,5 para 3,9 e no outono/inverno de 3,8 para 3,3 folhas vivas perfilho ${ }^{-1}$. O aumento na senescência foi gradativo ao longo das fases de rebrotação, sendo o outono/inverno a época em que o acúmulo de material senescente foi mais pronunciado (Tabela 40). A senescência acumulada de lâminas foliares esteve diretamente relacionada ao número médio de folhas senescentes e mortas por perfilho (Tabelas 41 e 42).

Tabela 39. Número médio de folhas vivas por perfilho em capim-Mombaça durante a rebrotação nas épocas do ano

\begin{tabular}{cccc}
\hline \multirow{2}{*}{ Épocas do ano } & \multicolumn{3}{c}{ Período de rebrotação } \\
& Inicial & Intermediário & Final \\
\hline Verão & $4,5 \mathrm{Ab}$ & $4,7 \mathrm{Aa}$ & $3,9 \mathrm{Bb}$ \\
Outono/Inverno & $(0,13)$ & $(0,17)$ & $(0,29)$ \\
& $3,8 \mathrm{Ac}$ & $3,2 \mathrm{Bb}$ & $3,3 \mathrm{Ac}$ \\
Primavera & $(0,26)$ & $(0,39)$ & $(0,24)$ \\
& $4,8 \mathrm{Ba}$ & $4,9 \mathrm{Aa}$ & $4,7 \mathrm{Ba}$ \\
Média & $(0,20)$ & $(0,16)$ & $(0,12)$ \\
& $4,4 \mathrm{~A}$ & $4,3 \mathrm{AB}$ & $4,0 \mathrm{~B}$ \\
& $(0,15)$ & $(0,17)$ & $(0,15)$ \\
\hline
\end{tabular}

Números entre parênteses correspondem ao erro padrão da média.

Médias na mesma coluna seguidas de mesma letra minúscula não diferem entre si $(\mathrm{P}>0,10)$. Médias na mesma linha seguidas de mesma letra maiúscula não diferem entre si $(P>0,10)$.

Quanto à senescência acumulada de lâminas foliares (Tabela 40), houve efeito de fase de rebrotação $(\mathrm{P}=0,0500)$ e época do ano $(\mathrm{P}=0,0013)$, além da interação fase de rebrotação x época do ano $(\mathrm{P}=0,0405)$. 
Tabela 40. Senescência acumulada de lâminas foliares por pastejo $\left(\mathrm{kg} \mathrm{ha}^{-1} \mathrm{de} \mathrm{MS}\right) \mathrm{em}$ capim-Mombaça durante a rebrotação nas épocas do ano

\begin{tabular}{cccc}
\hline Épocas do ano & \multicolumn{3}{c}{ Período de rebrotação } \\
& Inicial & Intermediário & Final \\
\hline Verão & $80 \mathrm{Cb}$ & $260 \mathrm{Bc}$ & $690 \mathrm{Ac}$ \\
& $(111)$ & $(146)$ & $(179)$ \\
Outono/Inverno & $610 \mathrm{Ca}$ & $1.800 \mathrm{Ba}$ & $3.440 \mathrm{Aa}$ \\
& $(203)$ & $(715)$ & $(1.325)$ \\
Primavera & $110 \mathrm{Cb}$ & $440 \mathrm{Bb}$ & $1.090 \mathrm{Ab}$ \\
& $(135)$ & $(167)$ & $(207)$ \\
Média & $270 \mathrm{C}$ & $840 \mathrm{~B}$ & $1.740 \mathrm{~A}$ \\
& $(120)$ & $(297)$ & $(511)$ \\
\hline
\end{tabular}

Números entre parênteses correspondem ao erro padrão da média.

Médias na mesma coluna seguidas de mesma letra minúscula não diferem entre si $(\mathrm{P}>0,10)$.

Médias na mesma linha seguidas de mesma letra maiúscula não diferem entre si $(\mathrm{P}>0,10)$.

O número de folhas senescentes e mortas por perfilho ao final do período de rebrotação dos tratamentos de $100 \%$ de IL foi de 2,6 flhas perfilho ${ }^{-1}$ enquanto que para os tratamentos de $95 \%$ de IL foi de 1,6 folha perfilho- ${ }^{-1}$ (Tabela 41). Além do efeito de interceptação luminosa $(\mathrm{P}=0,0966)$, foi constatado efeito de fase de rebrotação $(\mathrm{P}=0,0070)$, época do ano $(\mathrm{P}=0,0527)$ e interação época do ano $\mathrm{x}$ fase de rebrotação $(\mathrm{P}=0,0872)$. Houve aumento crescente dessa variável durante a rebrotação, tendo sido mais rápido nos tratamentos de $100 \%$ de IL. No início da estação de crescimento (primavera), foi registrado o menor número de folhas em senescência. Com o avançar da estação, houve um aumento nesse número até a chegada do outono/inverno, época em que foram registrados os maiores valores (Tabela 42).

Tabela 41. Número médio de folhas senescentes e mortas por perfilho em capimMombaça para os tratamentos de 95 e $100 \%$ de IL durante a rebrotação

\begin{tabular}{cccc}
\hline \multirow{2}{\text{Interceptação}}{\begin{tabular}{c}
\multicolumn{3}{c}{ Período de rebrotação } \\
luminosa $(\%)$
\end{tabular}} & Inicial & Intermediário & Final \\
\hline 95 & $0,7 \mathrm{Ca}$ & $1,3 \mathrm{Bb}$ & $1,6 \mathrm{Ab}$ \\
& $(0,12)$ & $(0,20)$ & $(0,21)$ \\
100 & $0,9 \mathrm{Ca}$ & $1,9 \mathrm{Ba}$ & $2,6 \mathrm{Aa}$ \\
& $(0,12)$ & $(0,20)$ & $(0,21)$ \\
Média & $0,8 \mathrm{C}$ & $1,6 \mathrm{~B}$ & $2,1 \mathrm{~A}$ \\
& $(0,09)$ & $(0,14)$ & $(0,15)$ \\
\hline
\end{tabular}

Números entre parênteses correspondem ao erro padrão da média.

Médias na mesma coluna seguidas de mesma letra minúscula não diferem entre si $(\mathrm{P}>0,10)$.

Médias na mesma linha seguidas de mesma letra maiúscula não diferem entre si $(P>0,10)$. 
Tabela 42. Número médio de folhas senescentes e mortas por perfilho em capimMombaça durante a rebrotação nas épocas do ano

\begin{tabular}{cccc}
\hline Época do ano & \multicolumn{3}{c}{ Período de rebrotação } \\
& Inicial & Intermediário & Final \\
\hline Verão & $0,70 \mathrm{Cb}$ & $1,27 \mathrm{Bb}$ & $1,98 \mathrm{Ab}$ \\
& $(0,12)$ & $(0,16)$ & $(0,14)$ \\
Outono/Inverno & $1,30 \mathrm{Ba}$ & $2,54 \mathrm{Aa}$ & $2,72 \mathrm{Aa}$ \\
& $(0,17)$ & $(0,32)$ & $(0,32)$ \\
Primavera & $0,42 \mathrm{Cc}$ & $0,85 \mathrm{Bc}$ & $1,59 \mathrm{Ac}$ \\
& $(0,07)$ & $(0,09)$ & $(0,16)$ \\
Média & $0,81 \mathrm{C}$ & $1,55 \mathrm{~B}$ & $2,10 \mathrm{~A}$ \\
& $(0,12)$ & $(0,23)$ & $(0,09)$ \\
\hline
\end{tabular}

Números entre parênteses correspondem ao erro padrão da média.

Médias na mesma coluna seguidas de mesma letra minúscula não diferem entre si $(\mathrm{P}>0,10)$.

Médias na mesma linha seguidas de mesma letra maiúscula não diferem entre si $(\mathrm{P}>0,10)$.

Apesar de não ter sido constatado efeito de interceptação luminosa $(P>0,10)$, a senescência acumulada de lâminas foliares é apresentada na Tabela 43 com o objetivo de assegurar a consistência de apresentação dos resultados e continuidade do raciocínio lógico iniciado no item 5.2.1.1.

Tabela 43. Senescência acumulada de lâminas foliares por pastejo $\left(\mathrm{kg} \mathrm{ha}^{-1} \mathrm{de} \mathrm{MS}\right) \mathrm{d}$ capim-Mombaça durante as épocas do ano

\begin{tabular}{ccccc}
\hline $\begin{array}{c}\text { Interceptação } \\
\text { luminosa (\%) }\end{array}$ & Verão & $\begin{array}{c}\text { Epocas do ano } \\
\text { Outono/inverno }\end{array}$ & Primavera & Média \\
\hline 95 & 520 & 2.250 & 440 & 1.070 \\
& $(255)$ & $(1.874)$ & $(294)$ & $(723)$ \\
100 & 860 & 4.630 & 1.740 & 2.410 \\
& $(255)$ & $(1.874)$ & $(294)$ & $(723)$ \\
Média & $690 \mathrm{C}$ & $3.440 \mathrm{~A}$ & $1.090 \mathrm{~B}$ & 1.740 \\
& $(178)$ & $(1.325)$ & $(208)$ &
\end{tabular}

Números entre parênteses correspondem ao erro padrão da média.

Médias na mesma linha seguidas de mesma letra maiúscula não diferem entre si (P>0,10).

A senescência acumulada de lâminas foliares por pastejo (Tabela 43) multiplicada pelo número de pastejos por época do ano (Tabela 3) resultou em um valor médio de senescência acumulada de folhas da ordem de $7.950 \mathrm{~kg} \mathrm{ha}^{-1}$ de MS para $95 \%$ de IL e de $12.920 \mathrm{~kg} \mathrm{ha}^{-1}$ de MS para $100 \%$ de IL. Assim, a senescência acumulada de folhas dos tratamentos de $100 \%$ de IL foi $4.970 \mathrm{~kg} \mathrm{ha}^{-1}$ de MS maior que aquela dos tratamentos de $95 \%$ de IL. 


\subsubsection{Acúmulo líquido}

O acúmulo líquido de lâminas foliares corresponde ao balanço dos processos de crescimento e senescência, neste caso caracterizados pela expansão e senescência de folhas, respectivamente. Houve efeito de resíduo $(\mathrm{P}=0,1100)$, fase de rebrotação $(\mathrm{P}=0,0081)$ e época do ano $(\mathrm{P}=0,0002)$, além das interações interceptação luminosa $\mathrm{x}$ fase de rebrotação $\mathrm{x}$ época do ano $(\mathrm{P}=0,1059)$, fase de rebrotação $\mathrm{x}$ época do ano $(\mathrm{P}=0,1009)$ e resíduo x época do ano $(\mathrm{P}=0,1066)$.

Os tratamentos de $95 \%$ e $100 \%$ de IL não diferiram $(\mathrm{P}>0,10)$ quanto ao acúmulo líquido de lâminas foliares quando considerados os valores por pastejo (Tabela 44) (Figura 24). Como o número de pastejos foi variável ao longo do período experimental para os tratamentos, este deve ser considerado. Assim, o acúmulo líquido de lâminas foliares por pastejo foi multiplicado pelo número de pastejos correspondente ao seu tratamento e, posteriormente, dividido pelo número médio de pastejos (média dos valores de cada tratamento) (Figura 25).

Tabela 44. Acúmulo líquido de lâminas foliares por pastejo $\left(\mathrm{kg} \mathrm{ha}^{-1}\right.$ de MS) no capimMombaça para os tratamentos com 95 e $100 \%$ de interceptação luminosa durante as épocas do ano

\begin{tabular}{ccccc}
\hline $\begin{array}{c}\text { Interceptação luminosa } \\
(\%)\end{array}$ & Verão & $\begin{array}{c}\text { Epocas do ano } \\
\text { Outono/Inverno }\end{array}$ & Primavera & Total \\
\hline 95 & $3.330 \mathrm{Aa}$ & $270 \mathrm{Ba}$ & $2.700 \mathrm{Aa}$ & 6.300 \\
& $(526)$ & $(1.770)$ & $(620)$ & $(493)$ \\
100 & $3.220 \mathrm{Aa}$ & $-140 \mathrm{Bb}$ & $2.550 \mathrm{Aa}$ & 5.630 \\
& $(526)$ & $(1.770)$ & $(620)$ & $(493)$ \\
Média & $3.280 \mathrm{~A}$ & $70 \mathrm{~B}$ & $2.630 \mathrm{~A}$ & 5.970 \\
& $(372)$ & $(1.250)$ & $(438)$ & \\
\hline
\end{tabular}

Números entre parênteses correspondem ao erro padrão da média.

Médias na mesma coluna seguidas de mesma letra minúscula não diferem entre si $(P>0,10)$.

Médias na mesma linha seguidas de mesma letra maiúscula não diferem entre si $(P>0,10)$. 


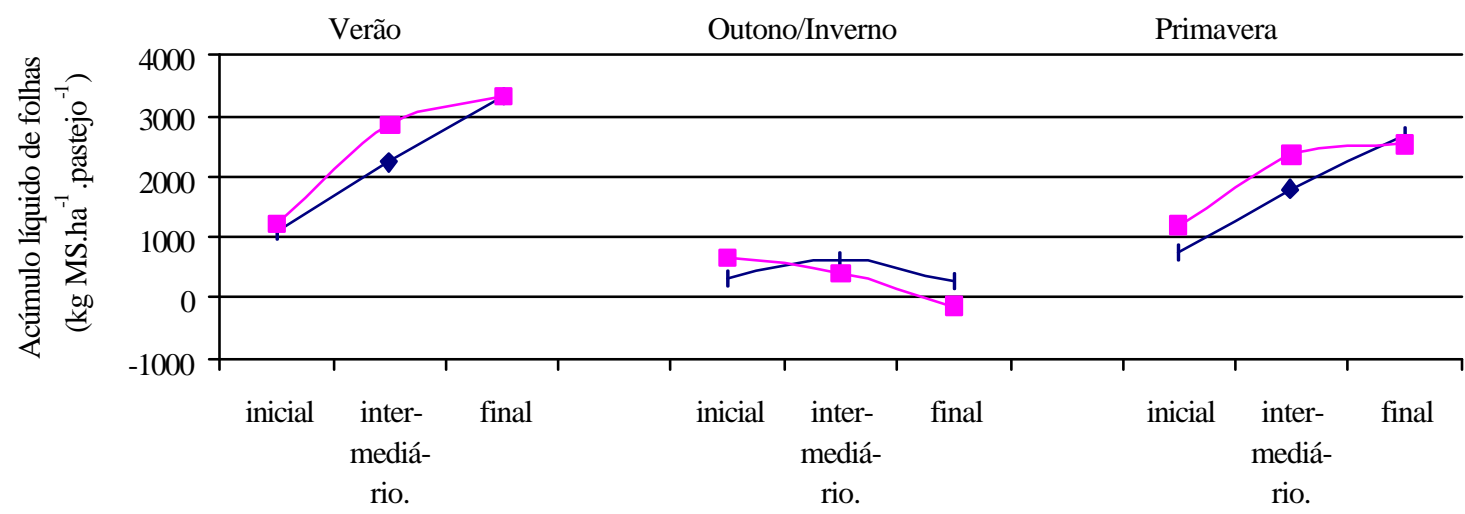

Periodo de rebrotação

$+95 \% \mathrm{IL}-100 \% \mathrm{IL}$

Figura 24- Acúmulo líquido de lâminas foliares por pastejo para os tratamentos de $95 \mathrm{e}$ $100 \%$ de interceptação luminosa durante a rebrotação nas épocas do ano

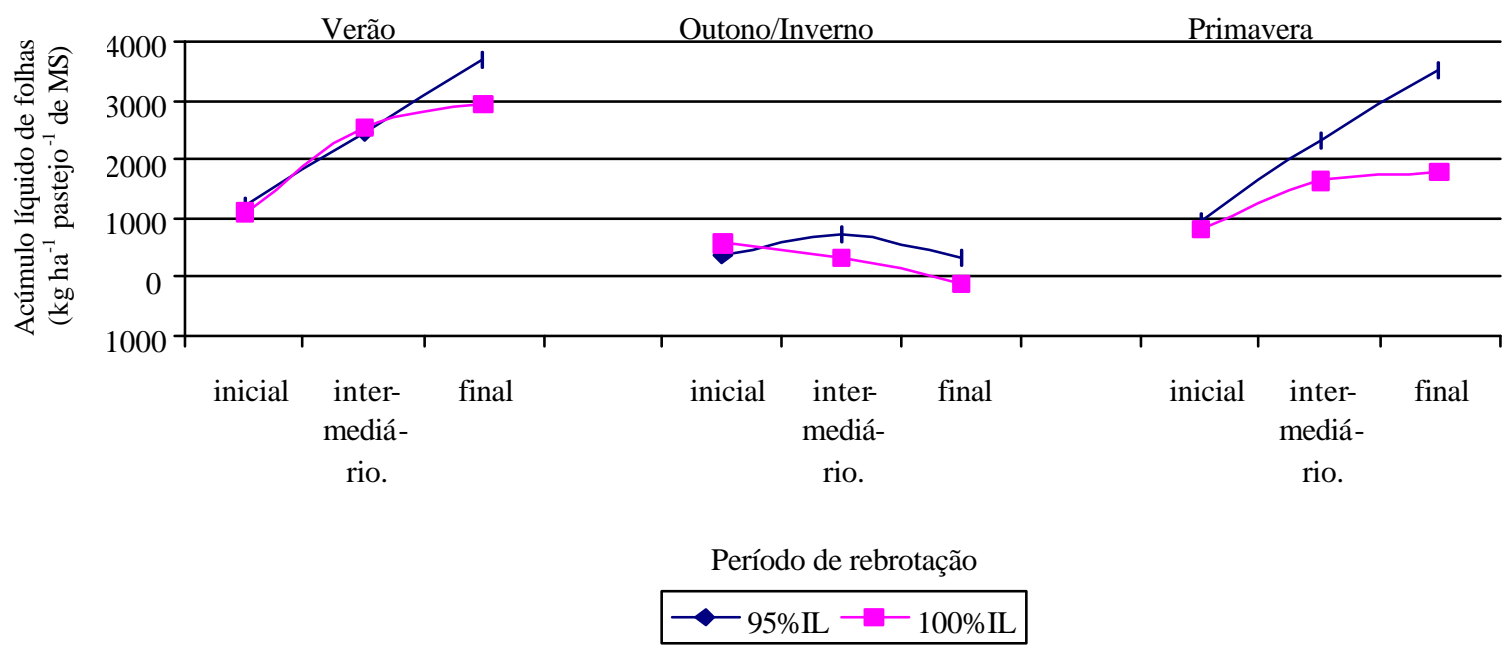

Figura 25- Acúmulo líquido de lâminas foliares corrigido para número de pastejos para os tratamentos com 95 e $100 \%$ de interceptação luminosa durante a rebrotação nas épocas do ano 
$\mathrm{O}$ acúmulo líquido de lâminas foliares por pastejo foi semelhante $(\mathrm{P}>0,10)$ durante a primavera e o verão (Tabela 45), porém bastante reduzido no outono/inverno, sendo que para os tratamentos de $100 \%$ de IL a senescência de folhas superou a expansão, promovendo acúmulo negativo (Tabela 44)

Tabela 45. Acúmulo líquido de lâminas foliares por pastejo ( $\left.\mathrm{kg} \mathrm{ha}^{-1} \mathrm{de} \mathrm{MS}\right)$ em capimMombaça durante a rebrotação nas épocas do ano

\begin{tabular}{cccc}
\hline Época do ano & Inicial & $\begin{array}{c}\text { Período de rebrotação } \\
\text { Intermediário }\end{array}$ & Final \\
\hline Verão & $1.150 \mathrm{Ca}$ & $2.520 \mathrm{Ba}$ & $3.290 \mathrm{Aa}$ \\
& $(114)$ & $(341)$ & $(352)$ \\
Outono/Inverno & $350 \mathrm{Ab}$ & $70 \mathrm{Ab}$ & $-360 \mathrm{Ab}$ \\
& $(194)$ & $(613)$ & $(980)$ \\
Primavera & $950 \mathrm{Ca}$ & $2.070 \mathrm{Ba}$ & $2.610 \mathrm{Aa}$ \\
& $(127)$ & $(288)$ & $(424)$ \\
Média & $820 \mathrm{~B}$ & $1.550 \mathrm{~A}$ & $1.850 \mathrm{~A}$ \\
& $(111)$ & $(320)$ & $(467)$ \\
\hline
\end{tabular}

Números entre parênteses correspondem ao erro padrão da média.

Médias na mesma coluna seguidas de mesma letra minúscula não diferem entre si $(\mathrm{P}>0,10)$.

Médias na mesma linha seguidas de mesma letra maiúscula não diferem entre si $(\mathrm{P}>0,10)$.

O acúmulo líquido de lâminas foliares no início do período de rebrotação no outono/inverno foi baixo, porém positivo (Tabela 45). No período intermediário o acúmulo líquido foi reduzido chegando quase a zero. No período final a redução continuou e o processo de senescência superou o de expansão foliar, resultando em acúmulo líquido negativo de lâminas foliares naquela época do ano. Nas demais épocas do ano (verão e primavera) o acúmulo líquido de lâminas foliares foi crescente ao longo do período de rebrotação.

Os tratamentos de resíduo $50 \mathrm{~cm}$ foram os responsáveis pelo acúmulo negativo de lâminas foliares ocorrido durante o outono/inverno (Tabela 46). A morte de folhas durante essa época do ano pode estar relacionada à redução no número de folhas vivas expandidas por perfilho. O número médio de folhas expandidas dos tratamentos de resíduo $50 \mathrm{~cm}$ foi de 3,4 folhas expandidas por perfilho (Tabela 47), havendo redução para 2,8 folhas expandidas no outono/inverno. Já o tratamento de $30 \mathrm{~cm}$ apresentava 2,8 
folhas expandidas mantendo o mesmo valor durante o outono/inverno $\mathrm{Na}$ primavera, o número de folhas expandidas foi de 3,7 , sendo posteriormente reduzido no verão $(3,2)$.

Tabela 46. Acúmulo líquido de lâminas foliares por pastejo $\left(\mathrm{kg} \mathrm{ha}^{-1} \mathrm{de} \mathrm{MS}\right)$ em capimMombaça para os tratamentos de 30 e $50 \mathrm{~cm}$ de resíduo durante as épocas do ano

\begin{tabular}{ccccc}
\hline $\begin{array}{c}\text { Resíduo } \\
(\mathrm{cm})\end{array}$ & Verão & $\begin{array}{c}\text { Época do ano } \\
\text { Outono/Inverno }\end{array}$ & Primavera & Média \\
\hline 30 & $3.350 \mathrm{Aa}$ & $1.370 \mathrm{Ba}$ & $3.350 \mathrm{Aa}$ & $2.690 \mathrm{a}$ \\
& $(526)$ & $(1.770)$ & $(620)$ & $(697)$ \\
50 & $3.300 \mathrm{Aa}$ & $-1.230 \mathrm{Cb}$ & $1.900 \mathrm{Bb}$ & $1.320 \mathrm{~b}$ \\
& $(526)$ & $(1.770)$ & $(620)$ & $(697)$ \\
Média & $3.330 \mathrm{~A}$ & $70 \mathrm{~B}$ & $2.630 \mathrm{~A}$ & 2.010 \\
& $(322)$ & $(1.250)$ & $(438)$ & \\
\hline
\end{tabular}

Números entre parênteses correspondem ao erro padrão da média.

Médias na mesma coluna seguidas de mesma letra minúscula não diferem entre si $(\mathrm{P}>0,10)$.

Médias na mesma linha seguidas de mesma letra maiúscula não diferem entre si $(\mathrm{P}>0,10)$. 
Tabela 47. Número médio de folhas expandidas por perfilho de capim-Mombaça para os tratamentos de 30 e $50 \mathrm{~cm}$ de resíduo durante a rebrotação

\begin{tabular}{cccc}
\hline Resíduo $(\mathrm{cm})$ & \multicolumn{3}{c}{$\begin{array}{c}\text { Período de rebrotação } \\
\text { Intermediário }\end{array}$} \\
\hline 30 & Inicial & Final \\
\hline \multirow{2}{*}{50} & $3,3 \mathrm{Aa}$ & $3,2 \mathrm{Aa}$ & $2,8 \mathrm{Bb}$ \\
& $(0,14)$ & $(0,18)$ & $(0,18)$ \\
Média & $3,4 \mathrm{Aa}$ & $3,3 \mathrm{Aa}$ & $3,4 \mathrm{Aa}$ \\
& $(0,14)$ & $(0,18)$ & $(0,18)$ \\
& 3,4 & 3,3 & 3,2 \\
& $(0,10)$ & $(0,11)$ & $(0,11)$ \\
\hline
\end{tabular}

Números entre parênteses correspondem ao erro padrão da média.

Médias na mesma coluna seguidas de mesma letra minúscula não diferem entre si $(\mathrm{P}>0,10)$.

Médias na mesma linha seguidas de mesma letra maiúscula não diferem entre si $(\mathrm{P}>0,10)$.

Para os tratamentos de $30 \mathrm{~cm}$ de resíduo, os valores de acúmulo líquido de lâminas foliares da primavera e verão foram semelhantes, enquanto que para os tratamentos de resíduo $50 \mathrm{~cm}$ o acúmulo da primavera foi reduzido (Tabela 46).

O acúmulo líquido de lâminas foliares no ano (expansão - senescência) foi de $17.950 \mathrm{~kg} \mathrm{ha}^{-1}$ de MS para os tratamentos de $95 \%$ de IL e de $11.620 \mathrm{~kg} \mathrm{ha}^{-1}$ de MS para os tratamentos de $100 \%$ de IL.

\subsubsection{Hastes}

\subsubsection{Crescimento (Alongamento)}

Além dos processos de crescimento e senescência de folhas, tradicionais em estudos com azevém perene, processos análogos ocorreram com a porção haste do capim-Mombaça. Houve efeito de interceptação luminosa $(\mathrm{P}=0,1116)$ e fase de rebrotação $(\mathrm{P}=0,0140)$ para as taxas de alongamento de hastes. A taxa média de alongamento de hastes durante a rebrotação dos tratamentos de $100 \%$ de IL foi cerca de $0,36 \mathrm{~cm}$ perfilho ${ }^{-1}$ dia $^{-1}$ enquanto que para os tratamentos de $95 \%$ de IL foi de $0,15 \mathrm{~cm}$ perfilho ${ }^{-1}$ dia $^{-1}$ (Tabela 48), independentemente dos resíduos estudados. As taxas aumentaram ao longo do processo de rebrotação, passando de 0,10 para 0,24 cm.perfilho ${ }^{-1}$ dia $^{-1}$ e de 0,27 para $0,42 \mathrm{~cm}_{\text {perfilho }}{ }^{-1}$ dia $^{-1}$ do período inicial para o final, respectivamente, para os tratamentos de $95 \%$ e $100 \%$ de IL. 
Tabela 48. Taxa de alongamento de hastes $\left(\mathrm{cm}\right.$ perfilho $\left.{ }^{-1} \mathrm{dia}^{-1}\right)$ no capim-Mombaça para os tratamentos de 95 e $100 \%$ de interceptação luminosa durante a rebrotação

\begin{tabular}{ccccc}
\hline Interceptação & \multicolumn{4}{c}{ Período de rebrotação } \\
luminosa (\%) & inicial & Intermediário & Final & Média \\
\hline 95 & 0,10 & 0,17 & 0,24 & $0,15 \mathrm{~b}$ \\
& $(0,067)$ & $(0,067)$ & $(0,054)$ & $(0,08)$ \\
100 & 0,27 & 0,33 & 0,42 & $0,36 \mathrm{a}$ \\
& $(0,067)$ & $(0,067)$ & $(0,054)$ & $(0,08)$ \\
Média & $0,19 \mathrm{C}$ & $0,25 \mathrm{~B}$ & $0,33 \mathrm{~A}$ & 0,26 \\
& $(0,066)$ & $(0,067)$ & $(0,048)$ & \\
\hline
\end{tabular}

Números entre parênteses correspondem ao erro padrão da média.

Médias na mesma coluna seguidas de mesma letra minúscula não diferem entre si $(P>0,10)$.

O alongamento acumulado de hastes no período experimental é apresentado nas Tabelas 49 e 50. Houve efeito de interceptação luminosa $(\mathrm{P}=0,0022)$, fase de rebrotação $(\mathrm{P}<0,0001)$ e época do ano $(\mathrm{P}=0,0596)$. $\mathrm{O}$ alongamento acumulado de hastes por pastejo no momento da entrada dos animais nos pastos (fase final) dos tratamentos de $100 \%$ de IL foi maior do que para os tratamentos de 95\% de IL (Tabela 49), sendo que um considerável aumento na massa acumulada de hastes foi observado do início ao final do processo de rebrotação (220 para $940 \mathrm{~kg} \mathrm{ha}^{-1}$ de MS para 95\% de IL e 450 para $2.630 \mathrm{~kg} \mathrm{ha}^{-1}$ de MS para $100 \%$ de IL). A massa de hastes acumulada de primavera foi de $610 \mathrm{~kg} \mathrm{ha}^{-1}$ de MS, aumentando no verão para $1.000 \mathrm{~kg} \mathrm{ha}^{-1}$ de MS e, posteriormente, para $1.200 \mathrm{~kg} \mathrm{ha}^{-1}$ de MS no outono/inverno para os tratamentos de $95 \%$ de IL. A progressão para os tratamentos de $100 \%$ de IL pode ser observada na Tabela 51. 
Tabela 49. Alongamento acumulado de hastes por pastejo ( $\mathrm{kg} \mathrm{ha}^{-1}$ de MS) em capimMombaça para os tratamentos de 95 e $100 \%$ de interceptação luminosa durante a rebrotação

\begin{tabular}{cccc}
\hline Interceptação luminosa & \multicolumn{3}{c}{ Período de rebrotação } \\
$(\%)$ & Inicial & Intermediário & Final \\
\hline 95 & 220 & 530 & 940 \\
& $(79)$ & $(160)$ & $(266)$ \\
100 & 450 & 1.330 & 2.630 \\
& $(79)$ & $(160)$ & $(266)$ \\
Média & $340 \mathrm{C}$ & $930 \mathrm{~B}$ & $1.780 \mathrm{~A}$ \\
& $(56)$ & $(113)$ & $(188)$ \\
\hline
\end{tabular}

Números entre parênteses correspondem ao erro padrão da média.

Médias na mesma coluna seguidas de mesma letra minúscula não diferem entre si $(\mathrm{P}>0,10)$.

Médias na mesma linha seguidas de mesma letra maiúscula não diferem entre si $(\mathrm{P}>0,10)$.

Tabela 50. Alongamento acumulado de hastes por pastejo ( $\mathrm{kg} \mathrm{ha}^{-1}$ de MS) em capimMombaça para os tratamentos com 95 e $100 \%$ de interceptação luminosa durante as épocas do ano

\begin{tabular}{ccccc}
\hline $\begin{array}{c}\text { Interceptação } \\
\text { luminosa (\%) }\end{array}$ & Verão & $\begin{array}{c}\text { Épocas do ano } \\
\text { Outono/Inverno }\end{array}$ & Primavera & Média \\
\hline 95 & 1.000 & 1.200 & 610 & $940 \mathrm{~b}$ \\
& $(358)$ & $(528)$ & $(311)$ & $(266)$ \\
100 & 2.650 & 2.990 & 2.240 & $2.630 \mathrm{a}$ \\
& $(358)$ & $(528)$ & $(311)$ & $(266)$ \\
Média & $1.830 \mathrm{AB}$ & $2.100 \mathrm{~A}$ & $1.430 \mathrm{~B}$ & 1.790 \\
& $(114)$ & $(207)$ & $(121)$ & \\
\hline
\end{tabular}

Números entre parênteses correspondem ao erro padrão da média.

Médias na mesma coluna seguidas de mesma letra minúscula não diferem entre si $(\mathrm{P}>0,10)$.

Médias na mesma linha seguidas de mesma letra maiúscula não diferem entre si $(P>0,10)$.

Assim como calculado para lâminas foliares, calculou-se o alongamento acumulado de hastes durante o ano a partir do número de pastejos de cada tratamento. Para os tratamentos de $95 \%$ de IL, o alongamento acumulado de hastes foi de $7.450 \mathrm{~kg}$ ha $^{-1}$ de MS e para os tratamentos de $100 \%$ de IL o acúmulo foi de $15.140 \mathrm{~kg} \mathrm{ha}^{-1}$ de MS.

\subsubsection{Encurtamento de bainhas foliares e Senescência de hastes}

Assim como na dinâmica de tecidos de lâminas foliares (secção 4.2.1.2) foram registrados eventos análogos na dinâmica de hastes caracterizados como encurtamento de bainha foliar e senescência de hastes. A análise dos dados revelou efeito de 
interceptação luminosa $(\mathrm{P}=0,0010)$, fase de rebrotação $(\mathrm{P}=0,0049)$ e época do ano $(\mathrm{P}<0,0001)$, além das interações interceptação luminosa $\mathrm{x}$ época do ano $(\mathrm{P}=0,0002)$ e época do ano $\mathrm{x}$ fase de rebrotação $(\mathrm{P}=0,0654)$ sobre as taxas de redução no comprimento das bainhas foliares.

Os tratamentos de $95 \%$ de $\mathrm{IL}$ resultaram em maiores taxas de redução no comprimento das bainhas foliares na primavera e no outono/inverno (Tabela 51). No verão, não houve diferença entre os tratamentos. Para os tratamentos de $100 \%$ de IL, as taxas de redução no comprimento da bainha foram semelhantes durante todo o ano. A maior taxa de redução no comprimento de bainhas foliares foi observada durante a primavera para os tratamentos de $95 \%$ de IL.

Tabela 51. Taxa de redução do comprimento das bainhas foliares $\left(\mathrm{cm}\right.$ perfilho ${ }^{-1} \mathrm{dia}^{-1}$ ) em capim-Mombaça para os tratamentos de 95 e $100 \%$ de interceptação luminosa durante as épocas do ano

\begin{tabular}{ccccc}
\hline $\begin{array}{c}\text { Interceptação } \\
\text { luminosa }(\%)\end{array}$ & Verão & $\begin{array}{c}\text { Épocas do ano } \\
\text { Outono/Inverno }\end{array}$ & Primavera & Média \\
\hline 95 & $0,71 \mathrm{Ba}$ & $0,59 \mathrm{Ba}$ & $1,80 \mathrm{Aa}$ & $1,03 \mathrm{a}$ \\
& $(0,132)$ & $(0,132)$ & $(0,132)$ & $(0,093)$ \\
100 & $0,64 \mathrm{Aa}$ & $0,37 \mathrm{Ab}$ & $0,54 \mathrm{Ab}$ & $0,52 \mathrm{~b}$ \\
& $(0,132)$ & $(0,132)$ & $(0,132)$ & $(0,093)$ \\
Média & $0,68 \mathrm{~B}$ & $0,48 \mathrm{~B}$ & $1,17 \mathrm{~A}$ & 0,78 \\
& $(0,093)$ & $(0,093)$ & $(0,093)$ & \\
\hline
\end{tabular}

Números entre parênteses correspondem ao erro padrão da média.

Médias na mesma coluna seguidas de mesma letra minúscula não diferem entre si $(\mathrm{P}>0,10)$.

Médias na mesma linha seguidas de mesma letra maiúscula não diferem entre si $(\mathrm{P}>0,10)$.

A elevada redução no comprimento de bainhas foliares durante a primavera para os tratamentos de $95 \%$ de IL ocorreu principalmente até a metade do período de rebrotação. Do início ao final do processo de rebrotação houve diminuição nas taxas de redução do comprimento de bainhas foliares, porém esse efeito foi significativo apenas na primavera (Tabela 52). 
Tabela 52. Taxa de redução do comprimento das bainhas foliares $\left(\mathrm{cm}\right.$ perfilho $\left.{ }^{-1} \mathrm{dia}^{-1}\right)$ em capim-Mombaça durante a rebrotação nas épocas do ano

\begin{tabular}{cccc}
\hline & \multicolumn{3}{c}{ Período de rebrotação } \\
Épocas do ano & Inicial & Intermediário & Final \\
\hline Verão & $0,71 \mathrm{Ab}$ & $0,83 \mathrm{Aa}$ & $0,48 \mathrm{Aa}$ \\
& $(0,161)$ & $(0,161)$ & $(0,161)$ \\
Outono/Inverno & $0,63 \mathrm{Ab}$ & $0,41 \mathrm{Ab}$ & $0,39 \mathrm{Aa}$ \\
& $(0,161)$ & $(0,161)$ & $(0,161)$ \\
Primavera & $1,71 \mathrm{Aa}$ & $1,05 \mathrm{Ba}$ & $0,73 \mathrm{Ba}$ \\
& $(0,161)$ & $(0,161)$ & $(0,161)$ \\
Média & $1,02 \mathrm{~A}$ & $0,76 \mathrm{AB}$ & $0,54 \mathrm{~B}$ \\
& $(0,093)$ & $(0,093)$ & $(0,093)$ \\
\hline
\end{tabular}

Números entre parênteses correspondem ao erro padrão da média.

Médias na mesma coluna seguidas de mesma letra minúscula não diferem entre si $(\mathrm{P}>0,10)$.

Médias na mesma linha seguidas de mesma letra maiúscula não diferem entre si $(P>0,10)$.

Outro fator importante no estudo da dinâmica do acúmulo de hastes é a senescência e morte desses tecidos. Houve efeito de interceptação luminosa $(\mathrm{P}=0,0073)$, fase de rebrotação $(\mathrm{P}=0,0105)$ e época do ano $(\mathrm{P}=0,0008)$, além das interações interceptação luminosa $\mathrm{x}$ época do ano $\mathrm{x}$ fase de rebrotação $(\mathrm{P}=0,0754)$ e fase de rebrotação $\mathrm{x}$ época do ano $(\mathrm{P}=0,0204)$.

As taxas de senescência de hastes foram menores para os tratamentos de $95 \%$ de IL em todas as épocas do ano (Tabela 53). O comportamento durante o período de rebrotação foi variável conforme a época do ano. No verão e outono/inverno, as taxas de senescência de hastes aumentaram até a metade do período de rebrotação. Do meio para o final do período de rebrotação as taxas foram estáveis ou sofreram redução. $\mathrm{Na}$ primavera, as taxas foram maiores no final do período de rebrotação. Em média, a primavera foi a estação que teve a menor perda de hastes por senescência e, também, a menor quantidade acumulada de hastes (Tabela 50). 
Tabela 53. Taxa de senescência de hastes (mg perfilho ${ }^{-1}$ dia $^{-1}$ ) em capim-Mombaça para os tratamentos de 95 e $100 \%$ de IL durante a rebrotação nas épocas do ano

\begin{tabular}{|c|c|c|c|}
\hline \multirow{2}{*}{$\begin{array}{l}\text { Interceptação } \\
\text { luminosa (\%) }\end{array}$} & \multicolumn{3}{|c|}{ Período de rebrotação } \\
\hline & Inicial & Intermediário & Final \\
\hline \multirow[b]{2}{*}{95} & & Verão & \\
\hline & $\begin{array}{r}0,38 \mathrm{Aa} \\
(0,804)\end{array}$ & $\begin{array}{l}1,38 \mathrm{Ab} \\
(1,429)\end{array}$ & $\begin{array}{r}0,88 \mathrm{Ab} \\
(2,773)\end{array}$ \\
\hline \multirow[t]{2}{*}{100} & $1,75 \mathrm{Ba}$ & $7,38 \mathrm{Aa}$ & $7,50 \mathrm{Aa}$ \\
\hline & $(0,804)$ & $(1,429)$ & $(2,773)$ \\
\hline \multirow[t]{2}{*}{ Média } & 1,06 B (b') & 4,38 A (a') & $4,19 \mathrm{~A}\left(\mathrm{a}^{\prime}\right)$ \\
\hline & $(0,568)$ & $(1,011)$ & $(1,961)$ \\
\hline \multirow[t]{2}{*}{ Média da época } & & & $\begin{array}{l}3,21 \mathrm{~A}^{\prime} \\
(1,023)\end{array}$ \\
\hline & \multicolumn{3}{|c|}{ Outono/ Inverno } \\
\hline 95 & $\begin{array}{l}1,13 \mathrm{Bb} \\
(0,812)\end{array}$ & $\begin{array}{c}3,63 \mathrm{Ab} \\
(1,436)\end{array}$ & $\begin{array}{l}4,00 \mathrm{Aa} \\
(2,804)\end{array}$ \\
\hline 100 & $\begin{array}{l}3,25 \mathrm{Ba} \\
(0,812)\end{array}$ & $\begin{array}{l}6,88 \mathrm{Aa} \\
(1,436)\end{array}$ & $\begin{array}{c}4,25 \mathrm{ABa} \\
(2,804)\end{array}$ \\
\hline Média & $\begin{array}{c}2,19 \mathrm{~B}\left(\mathrm{a}^{\prime}\right) \\
(0,574)\end{array}$ & $\begin{array}{c}5,25 \text { A (a') } \\
(1,015)\end{array}$ & $\begin{array}{c}\text { 4,13 Ab(a') } \\
(1,983)\end{array}$ \\
\hline Média da época & & & $\begin{array}{l}3,85 \mathrm{~A}^{\prime} \\
(1,032)\end{array}$ \\
\hline 95 & $\begin{array}{l}0,00 \mathrm{Aa} \\
(0,161)\end{array}$ & $\begin{array}{l}\text { Primavera } \\
0,00 \mathrm{Aa} \\
(0,334)\end{array}$ & $\begin{array}{l}0,63 \mathrm{Aa} \\
(1,184)\end{array}$ \\
\hline 100 & $\begin{array}{l}0,25 \mathrm{Ba} \\
(0,161)\end{array}$ & $\begin{array}{l}0,63 \mathrm{Ba} \\
(0,334)\end{array}$ & $\begin{array}{c}3,00 \mathrm{Aa} \\
(1,184)\end{array}$ \\
\hline Média & $\begin{array}{c}0,13 \mathrm{~B}\left(\mathrm{c}^{\prime}\right) \\
(0,114)\end{array}$ & $\begin{array}{c}0,31 \mathrm{~B}\left(\mathrm{~b}^{\prime}\right) \\
(0,236)\end{array}$ & $\begin{array}{c}1,81 \mathrm{~A}\left(\mathrm{~b}^{\prime}\right) \\
(0,837)\end{array}$ \\
\hline Média da época & & & $\begin{array}{l}0,75 \mathrm{~B}^{\prime} \\
(0,356)\end{array}$ \\
\hline Média das fases & $\begin{array}{c}1,13 \mathrm{~B} \\
(0,314)\end{array}$ & $\begin{array}{l}3,31 \mathrm{~A} \\
(0,560)\end{array}$ & $\begin{array}{l}3,38 \mathrm{~A} \\
(1,139)\end{array}$ \\
\hline
\end{tabular}

Números entre parênteses correspondem ao erro padrão da média.

Médias na mesma coluna seguidas de mesma letra minúscula não diferem entre si $(\mathrm{P}>0,10)$.

Médias na mesma linha seguidas de mesma letra maiúscula nãodiferem entre si $(\mathrm{P}>0,10)$.

Médias de épocas do ano seguidas de letras maiúsculas acrescidas de ( ") não diferem entre si $(\mathrm{P}>0,10)$.

Médias na mesma coluna seguidas de letras minúsculas acrescidas de (') não diferem entre si $(\mathrm{P}>0,10)$.

O desaparecimento acumulado de hastes em cada pastejo (senescência e redução do comprimento de bainhas foliares) $\mathrm{em} \mathrm{kg} \mathrm{ha}^{-1}$ de MS foi calculado com a finalidade de determinar o acúmulo líquido de hastes (alongamento - desaparecimento). Os valores médios obtidos são apresentados na Tabela 54. 
Tabela 54. Desaparecimento acumulado de hastes por pastejo(kg ha ${ }^{-1}$ de MS) em capimMombaça para os tratamentos de 95 e $100 \%$ de IL durante a rebrotação

\begin{tabular}{ccccc}
\hline $\begin{array}{c}\text { Interceptação luminosa } \\
(\%)\end{array}$ & Verão & $\begin{array}{c}\text { Épocas do ano } \\
\text { Outono/Inverno }\end{array}$ & Primavera & Média \\
\hline 95 & $670 \mathrm{Ca}$ & $1.570 \mathrm{Ab}$ & $1.120 \mathrm{Ca}$ & $1.120 \mathrm{~b}$ \\
& $(235)$ & $(235)$ & $(235)$ & $(107)$ \\
100 & $990 \mathrm{Ca}$ & $2.610 \mathrm{~A}$ & $1.430 \mathrm{Ba}$ & $1.680 \mathrm{a}$ \\
& $(235)$ & $(235)$ & $(235)$ & $(107)$ \\
Média & $830 \mathrm{C}$ & $2.090 \mathrm{~A}$ & $1.280 \mathrm{~B}$ & 1.400 \\
& $(167)$ & $(167)$ & $(167)$ & \\
\hline
\end{tabular}

Números entre parênteses correspondem ao erro padrão da média.

Médias na mesma coluna seguidas de mesma letra minúscula não diferem entre si $(\mathrm{P}>0,10)$.

Médias na mesma linha seguidas de mesma letra maiúscula não diferem entre si $(\mathrm{P}>0,10)$.

Com base no número de pastejos por época do ano e por tratamento (Tabela 3)

e no desaparecimento acumulado por época do ano e por pastejo, foi calculado o desaparecimento acumulado no ano que ficou em torno de $8.590 \mathrm{~kg} \mathrm{ha}^{-1}$ de MS para os tratamentos de $95 \%$ de IL e $9.180 \mathrm{~kg} \mathrm{ha}^{-1}$ de MS para os tratamentos de $100 \%$ de IL.

\subsubsection{Acúmulo líquido}

Houve efeito de interceptação luminosa $(\mathrm{P}=0,0078)$, fase de rebrotação $(\mathrm{P}=0,0662)$ e época do ano $(\mathrm{P}=0,0855)$, além de interações interceptação luminosa $\mathrm{x}$ fase de rebrotação $(\mathrm{P}=0,0305)$ e interceptação luminosa x época do ano $(\mathrm{P}=0,1148)$.

Os tratamentos de $95 \%$ de IL apresentaram acúmulo negativo de hastes durante toda a rebrotação, não havendo diferenças $(\mathrm{P}>0,10)$ entre os valores de fases individuais (Tabela 55). Para os tratamentos de $100 \%$ de $\mathrm{IL}$, o aumento no acúmulo de hastes foi consistente até o final do processo de rebrotação, sendo mais expressivo no terço final do período de rebrotação. Quanto à época do ano, houve acúmulo líquido positivo de hastes para os tratamentos de $95 \%$ de IL, apenas durante o verão (Tabela 56). 
Tabela 55. Acúmulo líquido de hastes por pastejo ( $\mathrm{kg} \mathrm{ha}^{-1}$ de MS) em capim-Mombaça para os tratamentos de 95 e 100\% de interceptação luminosa durante a rebrotação

\begin{tabular}{cccc}
\hline Interceptação & \multicolumn{3}{c}{ Período de rebrotação } \\
luminosa (\%) & Inicial & Intermediário & Final \\
\hline 95 & $-120 \mathrm{Aa}$ & $-320 \mathrm{Ab}$ & $-220 \mathrm{Ab}$ \\
& $(177)$ & $(177)$ & $(177)$ \\
100 & $20 \mathrm{Ba}$ & $300 \mathrm{Ba}$ & $850 \mathrm{Aa}$ \\
& $(177)$ & $(177)$ & $(177)$ \\
Média & $-50 \mathrm{~B}$ & $-10 \mathrm{~B}$ & $320 \mathrm{~A}$ \\
& $(126)$ & $(126)$ & $(126)$ \\
\hline
\end{tabular}

Números entre parênteses correspondem ao erro padrão da média.

Médias na mesma coluna seguidas de mesma letra minúscula não diferem entre si $(\mathrm{P}>0,10)$.

Médias na mesma linha seguidas de mesma letra maiúscula não diferem entre si $(P>0,10)$.

Tabela 56. Acúmulo líquido de hastes por pastejo $\left(\mathrm{kg} \mathrm{ha}^{-1}\right.$ de MS) em capim-Mombaça para os tratamentos de 95 e $100 \%$ de interceptação luminosa durante as épocas do ano

\begin{tabular}{|c|c|c|c|c|}
\hline \multirow{2}{*}{$\begin{array}{l}\text { Interceptação } \\
\text { luminosa (\%) }\end{array}$} & \multicolumn{3}{|c|}{ Epocas do ano } & \multirow[b]{2}{*}{ Média } \\
\hline & Verão & Outono / Inverno & Primavera & \\
\hline 95 & $\begin{array}{l}250 \mathrm{Ab} \\
(346)\end{array}$ & $\begin{array}{c}-350 \mathrm{ABb} \\
(346)\end{array}$ & $\begin{array}{c}-550 \mathrm{Bb} \\
(346)\end{array}$ & $\begin{array}{c}-220 \mathrm{~b} \\
(177)\end{array}$ \\
\hline 100 & $\begin{array}{c}\text { 1.320 Aa } \\
(346)\end{array}$ & $\begin{array}{l}470 \mathrm{Aa} \\
(346)\end{array}$ & $\begin{array}{l}770 \text { Aa } \\
(346)\end{array}$ & $\begin{array}{l}850 \mathrm{a} \\
(177)\end{array}$ \\
\hline Média & $\begin{array}{l}780 \mathrm{~A} \\
(245)\end{array}$ & $\begin{array}{l}60 \mathrm{~B} \\
(245)\end{array}$ & $\begin{array}{l}110 \mathrm{~B} \\
(245)\end{array}$ & 320 \\
\hline
\end{tabular}

Números entre parênteses correspondem ao erro padrão da média.

Médias na mesma coluna seguidas de mesma letra minúscula não diferem entre si $(\mathrm{P}>0,10)$.

Médias na mesma linha seguidas de mesma letra maiúscula não diferem entre si $(\mathrm{P}>0,10)$.

As Figuras 26 e 27 apresentam os valores de acúmulo líquido de hastes dos tratamentos de 95 e $100 \%$ de IL, sendo que a primeira apresenta as médias por pastejo e a segunda apresenta os valores corrigidos para o número médio de pastejos. Nota-se o diferencial do acúmulo líquido de hastes entre os tratamentos de 95 e $100 \%$ de IL provocado pelo maior período de rebrotação nos tratamentos de 100\% de IL (Figura 26). A diferença aumenta quando é levado em consideração o número médio de pastejos (Figura 27) 


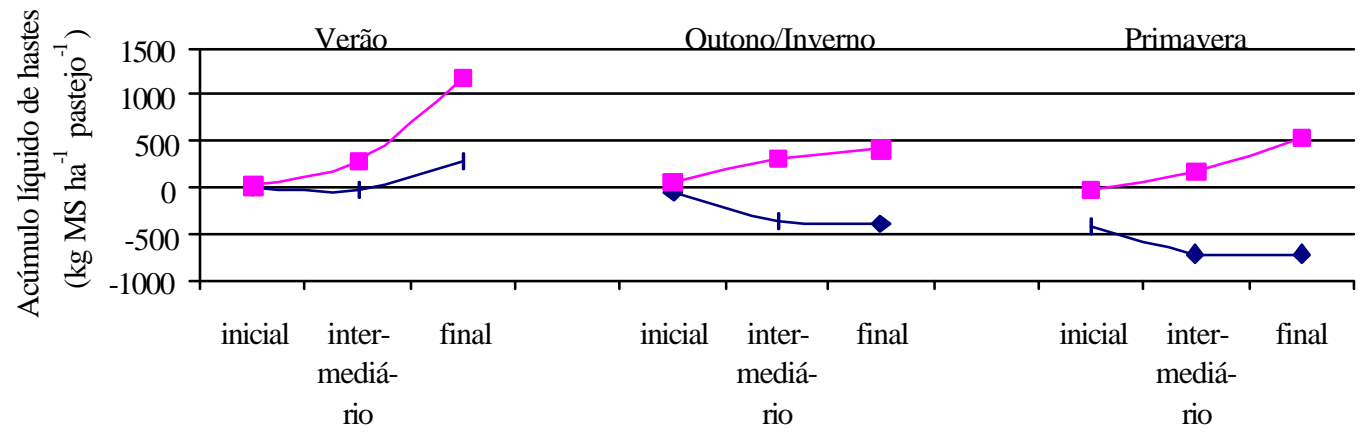

Periodo de rebrotação

$-95 \% \mathrm{IL}-100 \% \mathrm{IL}$

Figura 26- Acúmulo líquido de hastes por pastejo para os tratamentos com 95 e 100\% de interceptação luminosa durante as fases de rebrotação nas épocas do ano

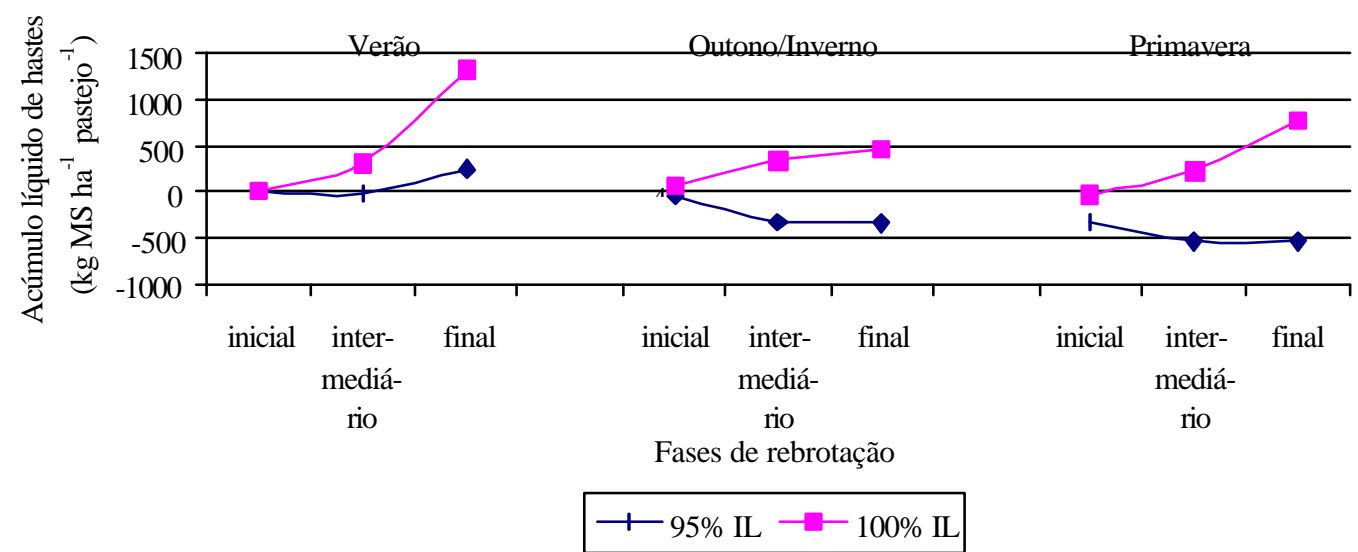

Figura 27- Acúmulo líquido de hastes corrigido para o número de pastejos realizados para os tratamentos com 95 e $100 \%$ de interceptação luminosa durante as fases de rebrotação nas épocas do ano 
O acúmulo líquido de hastes no ano (alongamento - desaparecimento) foi de $-1.140 \mathrm{~kg} \mathrm{ha}^{-1}$ de MS para os tratamentos de 95\% de IL, ou seja, o alongamento de hastes foi menor que e a senescência e o encurtamento de bainhas foliares. Para os tratamentos de $100 \%$ de IL o acúmulo líquido de hastes foi de $5.960 \mathrm{~kg} \mathrm{ha}^{-1}$ de MS.

\subsubsection{Acúmulo líquido de massa seca total}

De acordo com os valores obtidos na análise da dinâmica de acúmulo de hastes e lâminas foliares, foram calculados o crescimento e a senescencia/desaparecimento total de lâminas foliares e hastes, assim como o acúmulo líquido de cada um desses componentes (Tabela 57) para os tratamentos que apresentaram resultados mais expressivos (95 e 100\% de IL).

Tabela 57. Acúmulo líquido ( $\mathrm{kg} \mathrm{ha}^{-1}$ de MS) em capim-Mombaça para os tratamentos de 95 e $100 \%$ de interceptação luminosa durante o ano

\begin{tabular}{lcc}
\hline & \multicolumn{2}{c}{ Interceptação luminosa (\%) } \\
& 95 & 100 \\
\hline \multirow{2}{*}{$\begin{array}{l}\text { Crescimento } \\
\text { Senescência }\end{array}$} & Lâminas Foliares & \\
Acúmulo Líquido & 25.900 & 24.540 \\
& 7.950 & 12.920 \\
Crescimento & 17.950 & 11.620 \\
Senescência/Encurtamento & Hastes & \\
Acúmulo Líquido & 7.450 & 15.140 \\
& 8.590 & 9.180 \\
Acúmulo Líquido & Lâminas foliares + Hastes & 5.960 \\
\hline
\end{tabular}

O crescimento total para os tratamentos de $95 \%$ de IL foi menor que para os tratamentos com $100 \%$ de IL. Já o acúmulo líquido foi bastante próximo para os dois tratamentos, contudo, o diferencial apareceu na composição desse acúmulo. Observa-se que para o tratamento de $95 \%$ de IL, a forragem produzida foi composta de $100 \%$ de lâminas foliares, enquanto que nos tratamentos de $100 \%$ de IL a massa seca apresentou 
$68 \%$ de lâminas foliares e $32 \%$ de hastes. O acúmulo de material senescente e morto foi superior nos tratamentos de $100 \%$ de IL (22.100 $\mathrm{kg} \mathrm{ha}^{-1}$ de MS) em relação aos tratamentos de $95 \%$ de IL (16.540 $\mathrm{kg} \mathrm{ha}^{-1}$ de MS). A maior produção de material morto e hastes na base do dossel pelos tratamentos de 100\% de IL em relação aos tratamentos de 95\% de IL pode ser visualizada pela Figura 28. Apesar de superestimados, os valores de acúmulo obtidos através da análise da dinâmica de acúmulo de forragem seguem o mesmo padrão àqueles obtidos através de amostragem por corte da forragem.

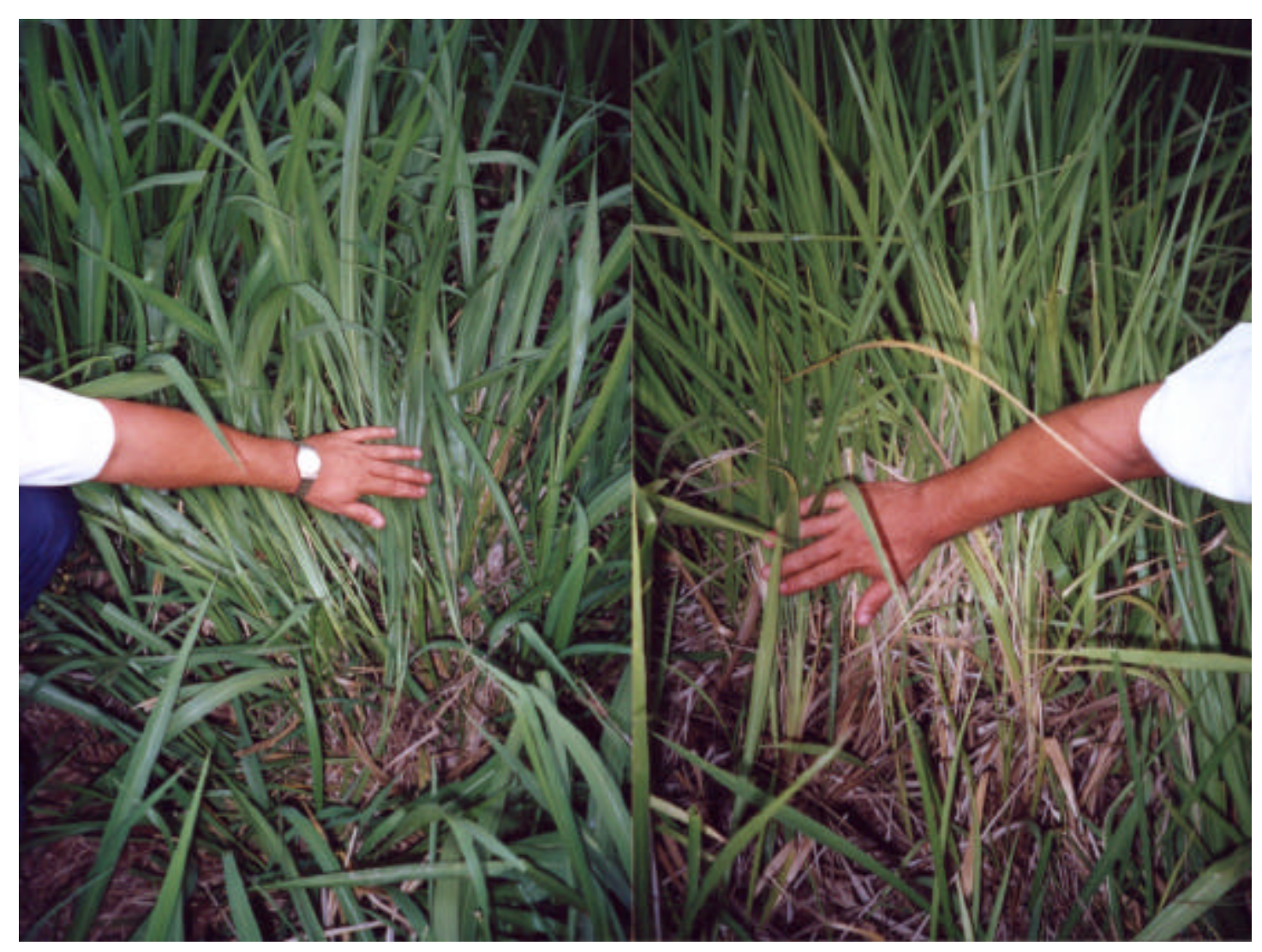

(a)

(b)

Figura 28- Estrutura do dossel forrageiro de capim-Mombaça em condição de prépastejo para os tratamentos de 95 (a) e $100 \%$ de IL (b) 


\subsection{Produção de forragem}

A produção de forragem foi avaliada por meio do corte da massa de forragem em pós e pré-pastejos sucessivos e os valores registrados para cada pastejo foram agrupados por época do ano. Houve efeito de época do ano $(\mathrm{P}<0,0001)$ e resíduo $(\mathrm{P}=0,0235)$, além da interação interceptação luminosa x época do ano $(\mathrm{P}=0,1027)$.

Os tratamentos de resíduo $30 \mathrm{~cm}$ resultaram nas maiores produções de forragem do experimento (Tabela 58). A maior produção medida foi a do tratamento 30/95 (26.900 $\mathrm{kg} \mathrm{ha}^{-1}$ de MS) que, no entanto, não diferiu do tratamento 30/100 (24.900 $\mathrm{kg} \mathrm{ha}^{-1}$ de MS) (P>0,10). Os tratamentos de 95\% de IL (22.410 $\mathrm{kg} \mathrm{ha}^{-1}$ de MS) acumularam a mesma quantidade de forragem que os tratamentos de $100 \%$ de IL (22.590 kg ha ${ }^{-1}$ de MS $)(P>0,10)$.

Tabela 58. Produção de forragem $\left(\mathrm{kg} \mathrm{ha}^{-1}\right.$ de $\left.\mathrm{MS}\right)$ de capim-Mombaça submetido a regimes de pastejo intermitente

\begin{tabular}{cccc}
\hline $\begin{array}{c}\text { Resíduo } \\
(\mathrm{cm})\end{array}$ & \multicolumn{3}{c}{ Interceptação luminosa (\%) } \\
\hline 30 & 26.900 & 24.900 & Média \\
& $(2.493)$ & $(2.493)$ & $25.900 \mathrm{a}$ \\
50 & 17.920 & 20.280 & $19.104)$ \\
& $(2.493)$ & $(2.493)$ & $(1.764)$ \\
Média & 22.410 & 22.590 & 22.500 \\
& $(1.764)$ & $(1.764)$ & \\
\hline
\end{tabular}

Números entre parênteses correspondem ao erro padrão da média.

Médias na mesma coluna seguidas de mesma letra minúscula não diferem entre si $(\mathrm{P}>0,10)$.

Com relação às épocas do ano, a maior produção de forragem foi observada no verão (9.930 $\mathrm{kg} \mathrm{ha}^{-1}$ de MS). No outono/inverno e primavera as produções foram semelhantes (5.900 e $6.670 \mathrm{~kg} \mathrm{ha}^{-1}$ de MS, respectivamente) (P>0,10) (Tabela 59). 
Tabela 59. Produção de forragem $\left(\mathrm{kg} \mathrm{ha}^{-1}\right.$ de MS) de capim-Mombaça para os tratamentos de 95 e $100 \%$ de IL durante as épocas do ano

\begin{tabular}{ccccc}
\hline $\begin{array}{c}\text { Interceptação } \\
\text { luminosa (\%) }\end{array}$ & Verão & $\begin{array}{c}\text { Época do ano } \\
\text { Outono/Inverno }\end{array}$ & Primavera & Total \\
\hline 95 & $10.680 \mathrm{Aa}$ & $5.250 \mathrm{Ba}$ & $6.480 \mathrm{Ba}$ & 22.410 \\
& $(785)$ & $(785)$ & $(785)$ & $(1.764)$ \\
100 & $9.180 \mathrm{Aa}$ & $6.550 \mathrm{Ba}$ & $6.860 \mathrm{Ba}$ & 22.590 \\
& $(785)$ & $(785)$ & $(785)$ & $(1.764)$ \\
Média & $9.930 \mathrm{~A}$ & $5.900 \mathrm{~B}$ & $6.670 \mathrm{~B}$ & 22.500 \\
& $(555)$ & $(555)$ & $(555)$ & \\
\hline
\end{tabular}

Números entre parênteses correspondem ao erro padrão da média.

Médias na mesma coluna seguidas de mesma letra minúscula não diferem entre si $(\mathrm{P}>0,10)$.

Médias na mesma linha seguidas de mesma letra maiúscula não diferem entre si $(\mathrm{P}>0,10)$.

As taxas mensais de acúmulo de forragem são apresentadas na Tabela 60. Houve efeito de resíduo $(\mathrm{P}=0,0921)$ e época do ano $(\mathrm{P}<0,0001)$ e das interações interceptação luminosa $\mathrm{x}$ época do ano $(\mathrm{P}=0,0003)$, resíduo x época do ano $(\mathrm{P}=0,0003) \mathrm{e}$ interceptação luminosa $\mathrm{x}$ resíduo x época do ano $(\mathrm{P}=0,0090)$. Os tratamentos de $95 \%$ de IL superaram os tratamentos de $100 \%$ de IL durante os meses de janeiro e fevereiro. Nos outros meses do ano as taxas de acúmulo foram praticamente iguais $(\mathrm{P}>0,10)$ (Tabela 59). Nos meses de outono/inverno e em dezembro, os tratamentos de $30 \mathrm{~cm}$ de resíduo apresentaram taxas de acúmulo superiores àquelas dos tratamentos de $50 \mathrm{~cm}$. Nos demais meses essa diferença não existiu $(\mathrm{P}>0,10)$.

Tabela 60. Taxas mensais de acúmulo de forragem $\left(\mathrm{kg} \mathrm{ha}^{-1} \mathrm{dia}^{-1} \mathrm{de} \mathrm{MS}\right)$ para o capimMombaça submetido a regimes de pastejo intermitente durante os meses do ano

\begin{tabular}{|c|c|c|c|}
\hline \multicolumn{4}{|c|}{ Interceptação luminosa (\%) } \\
\hline Resíduo(cm) & 95 & 100 & Média \\
\hline \multicolumn{4}{|c|}{ Janeiro } \\
\hline 30 & $147 \mathrm{Aa}(19,7)$ & $118 \mathrm{Ba}(19,7)$ & 132 a $(12,0)$ \\
\hline 50 & 133 Аa $(19,7)$ & $103 \mathrm{Ba}(19,7)$ & 118 a $(12,0)$ \\
\hline Média & 140 A $(14,0)$ & $110 \mathrm{~B}(14,0)$ & $125 \mathrm{~A}^{\prime}(8,5)$ \\
\hline \multicolumn{4}{|c|}{ Fevereiro } \\
\hline 30 & $103 \mathrm{Ab}(28,9)$ & $88 \mathrm{Ba}(28,9)$ & $95 \mathrm{a}(17,5)$ \\
\hline 50 & 164 Аа $(28,9)$ & $72 \mathrm{Ba}(28,9)$ & 118 a $(17,5)$ \\
\hline Média & 134 A $(20,4)$ & $80 \mathrm{~B}(20,4)$ & $107 \mathrm{~B}^{\prime}(12,4)$ \\
\hline
\end{tabular}




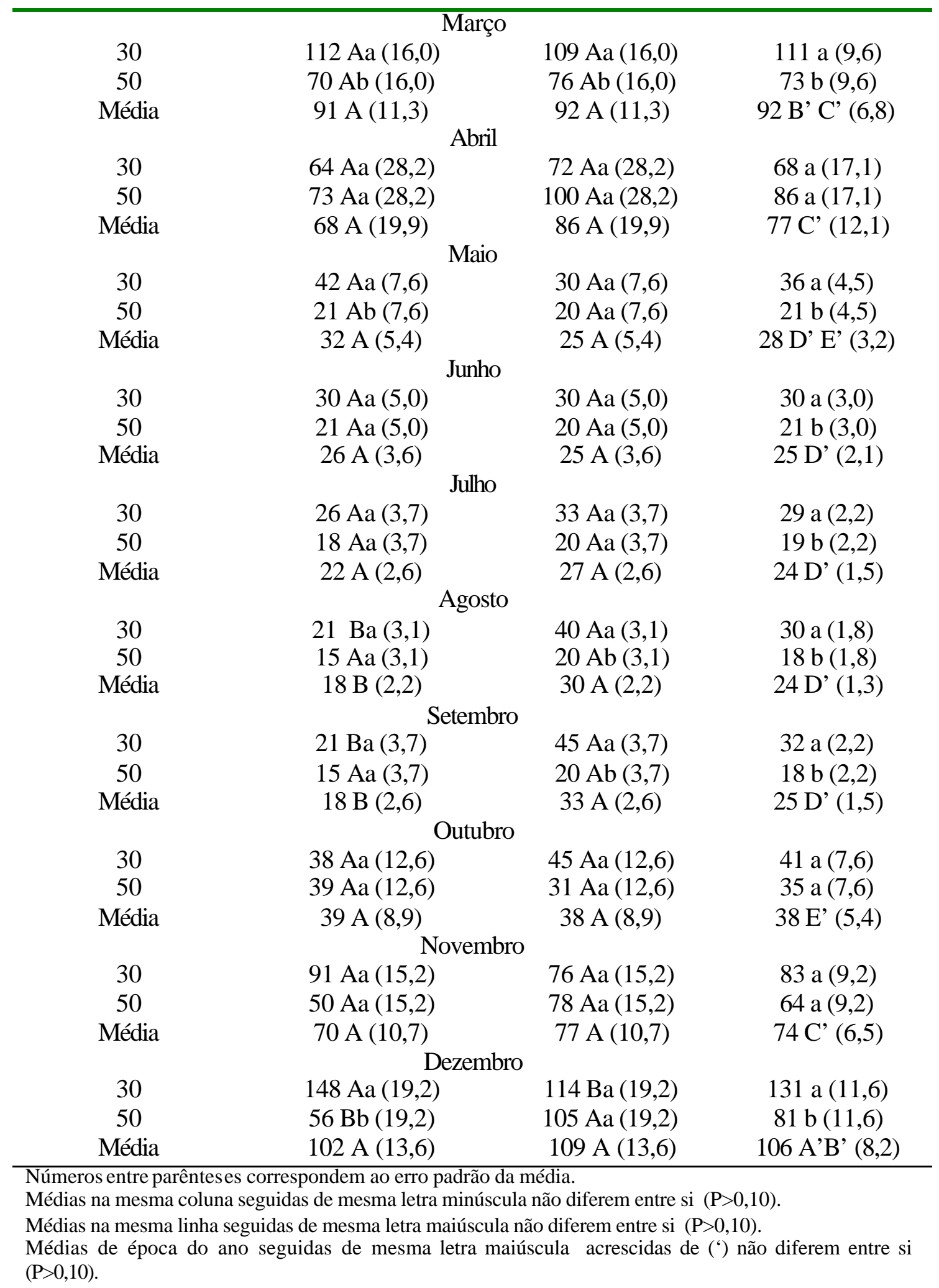


As maiores taxas de acúmulo foram observadas nos meses de verão (164 kg $\mathrm{ha}^{-1} \mathrm{dia}^{-1}$ de MS), seguidas dos meses da primavera (100 $\left.\mathrm{kg} \mathrm{ha}^{-1} \mathrm{dia}^{-1} \mathrm{de} \mathrm{MS}\right) \mathrm{e}$ outono/inverno (15 $\mathrm{kg} \mathrm{ha}^{-1} \mathrm{dia}^{-1}$ de MS), revelando acentuada estacionalidade de produção de forragem (Figura 29).

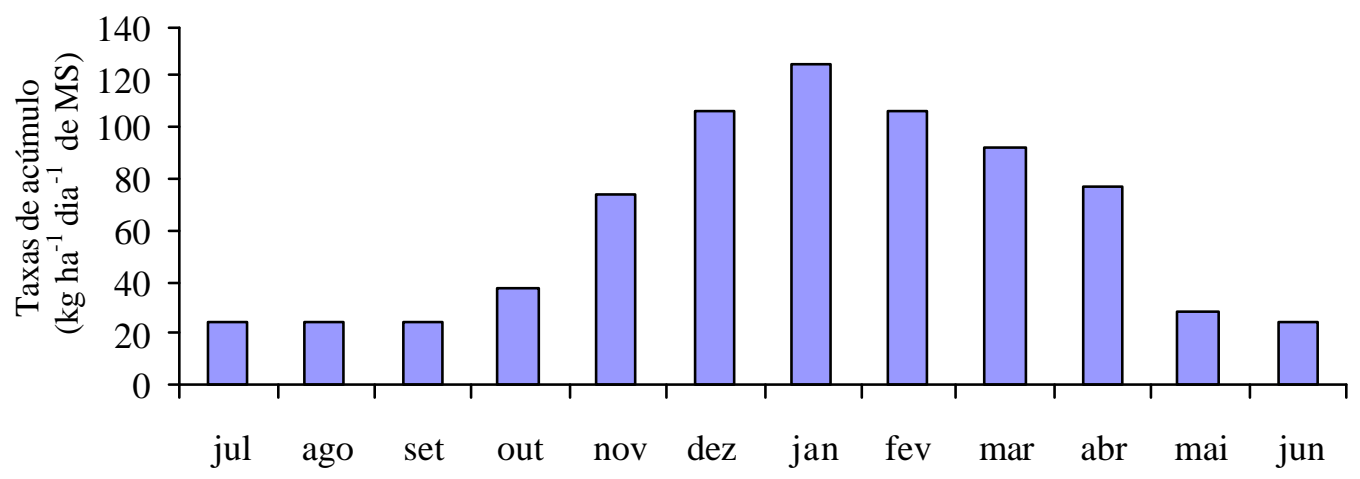

Figura 29- Médias mensais das taxas de acúmulo de forragem no capim-Mombaça

\subsection{Perdas de forragem pelo pastejo}

De toda a massa de forragem acumulada durante o período de rebrotação (intervalo entre pastejos), somente parte foi retirada do pasto pelos animais através do pastejo. Essa forragem retirada pode ter sido efetivamente ingerida pelos animais ou desperdiçada. À porção da massa de forragem retirada do pasto denominou-se forragem removida. A altura de resíduo pós-pastejo foi a principal responsável pela massa de forragem removida. A análise de variância para esta variável revelou efeito de época do ano $(\mathrm{P}<0,0001)$ e resíduo $(\mathrm{P}=0,0209)$. Os tratamentos de $30 \mathrm{~cm}$ de resíduo promoveram uma remoção $5.630 \mathrm{~kg} \mathrm{ha}^{-1}$ de MS superior à remoção de forragem dos tratamentos de $50 \mathrm{~cm}$ de resíduo (Tabela 61). A época do ano em que ocorreu a maior remoção de forragem $\left(9.970 \mathrm{~kg} \mathrm{ha}^{-1} \mathrm{de}\right.$ MS) foi a época de maior produção, o verão. 
Tabela 61. Massa de forragem removida $\left(\mathrm{kg} \mathrm{ha}^{-1}\right.$ de MS) durante o pastejo de capimMombaça para os tratamentos de 30 e $50 \mathrm{~cm}$ de resíduo nas épocas do ano

\begin{tabular}{ccccc}
\hline $\begin{array}{c}\text { Resíduo } \\
(\mathrm{cm})\end{array}$ & Verão & Outono/Inverno & Primavera & Total \\
\hline 30 & 11.540 & 4.800 & 6.130 & $22.470 \mathrm{a}$ \\
& $(1.411)$ & $(779)$ & $(770)$ & $(1.170)$ \\
50 & 8.390 & 4.140 & 4.310 & $16.840 \mathrm{~b}$ \\
& $(1.411)$ & $(779)$ & $(770)$ & $(1.170)$ \\
Média & $9.970 \mathrm{~A}$ & $4.470 \mathrm{~B}$ & $5.220 \mathrm{~B}$ & \\
& $(613)$ & $(613)$ & $(613)$ & \\
\hline
\end{tabular}

Números entre parênteses correspondem ao erro padrão da média.

Médias na mesma coluna seguidas de mesma letra minúsaula não diferem entre si $(\mathrm{P}>0,10)$.

Médias na mesma linha seguidas de mesma letra maiúscula não diferem entre si $(P>0,10)$.

Contudo, nem toda a forragem removida chega ao trato digestivo dos animais em pastejo. Parte é perdida no processo de colheita, ficando sobre o solo e/ou aderida à própria touceira, sendo rejeitada pelos animais. São as perdas geradas pelo pastejo. A análise revelou efeito de interceptação luminosa $(\mathrm{P}=0,0318)$ e época do ano $(\mathrm{P}=0,0022)$, além da interação resíduo $\mathrm{x}$ interceptação luminosa x época do ano $(\mathrm{P}=0,0534)$ para os valores de perda de forragem. Os tratamentos de $95 \%$ de IL proporcionaram menores perdas de forragem $\left(4.060 \mathrm{~kg} \mathrm{ha}^{-1}\right.$ de MS) que os tratamentos de $100 \%$ de IL (5.860 kg $\mathrm{ha}^{-1}$ de MS) (Tabela 62). Os tratamentos de $95 \%$ de IL proporcionaram uma perda total de forragem $45 \%$ menor que aquelas dos tratamentos de $100 \%$ de IL. Considerando a forragem removida de 19.870 para $95 \%$ de IL e $20.460 \mathrm{~kg} \mathrm{ha}^{-1}$ de MS para $100 \%$ de IL $(\mathrm{P}>0,10)$ e as perdas apresentadas na Tabela 62, obtém-se um aproveitamento da forragem (utilização) de 15.810 e $14.600 \mathrm{~kg} \mathrm{ha}^{-1}$ de MS para 95 e $100 \%$ de IL, respectivamente, ou seja, cerca de 79 e $71 \%$ de eficiência de utilização da forragem removida.

As perdas totais pela ação de pastejo foram de 4.470 e $5.450 \mathrm{~kg} \mathrm{ha}^{-1}$ de MS para os tratamentos de resíduos 30 e $50 \mathrm{~cm}$, respectivamente. O aproveitamento da forragem removida para os tratamentos de $30 \mathrm{~cm}$ de resíduo foi de $18.000 \mathrm{~kg} \mathrm{ha}^{-1}$ de MS e a eficiência de utilização de $80 \%$. Para os tratamentos de $50 \mathrm{~cm}$ de resíduo, o aproveitamento da forragem removida foi de $11.390 \mathrm{~kg} \mathrm{ha}^{-1}$ de MS e a eficiência de utilização de $68 \%$. 
Tabela 62. Perdas de forragem totais $\left(\mathrm{kg} \mathrm{ha}^{-1}\right.$ de MS) durante o pastejo de capimMombaça

\begin{tabular}{cccc}
\hline \multirow{2}{*}{ Resíduo $(\mathrm{cm})$} & & Interceptação Luminosa (\%) & Média \\
\hline 30 & $3.120 \mathrm{Bb}$ & $5.810 \mathrm{Aa}$ & 4.470 \\
& $(778)$ & $(778)$ & $(550)$ \\
50 & $5.000 \mathrm{Aa}$ & $5.900 \mathrm{Aa}$ & 5.450 \\
& $(778)$ & $(778)$ & $(550)$ \\
Média & $4.060 \mathrm{~B}$ & $5.860 \mathrm{~A}$ & 4.960 \\
& $(550)$ & $(550)$ & \\
\hline
\end{tabular}

Médias na mesma linha seguidas de mesma letra maiúscula não diferem entre si $(\mathrm{P}>0,10)$.

Médias na mesma coluna seguidas de mesma letra minúsculas não diferem entre si $(\mathrm{P}>0,10)$.

O tratamento 30/95 apresentou as menores perdas pelo pastejo durante o verão e outono/inverno (Tabela 63). Na primavera, o menor valor de perda por pastejo registrado foi para o tratamento 30/100, tratamento que resultou no menor número de pastejos naquela época do ano (Tabela 3). No campo foi possível constatar visualmente esse fato (Figura 30). 
Tabela 63. Perdas de forragem $\left(\mathrm{kg} \mathrm{ha}^{-1}\right.$ de MS) durante o pastejo no capim-Mombaça nas combinações de interceptação luminosa e intensidade de pastejo nas épocas do ano

\begin{tabular}{|c|c|c|c|}
\hline \multirow[t]{2}{*}{ Resíduo $(\mathrm{cm})$} & \multicolumn{3}{|c|}{ Interceptação luminosa (\%) } \\
\hline & 95 & 100 & Média \\
\hline \multicolumn{4}{|c|}{ Verão } \\
\hline 30 & $\begin{array}{c}1.050 \mathrm{Bb} \\
(855)\end{array}$ & $\begin{array}{c}3.420 \mathrm{Aa} \\
(855)\end{array}$ & $\begin{array}{l}2.240 \\
(521)\end{array}$ \\
\hline 50 & $\begin{array}{c}2.810 \mathrm{Aa} \\
(855)\end{array}$ & $\begin{array}{c}2.860 \mathrm{Aa} \\
(855)\end{array}$ & $\begin{array}{l}2.840 \\
(521)\end{array}$ \\
\hline Média & $\begin{array}{c}1.930 \mathrm{~A} \\
(690)\end{array}$ & $\begin{array}{c}3.140 \mathrm{~A} \\
(690)\end{array}$ & $\begin{array}{c}2.530 \mathrm{~A}^{\prime} \\
(488)\end{array}$ \\
\hline \multicolumn{4}{|c|}{ Outono/Inverno } \\
\hline 30 & $\begin{array}{c}640 \mathrm{Ba} \\
(250)\end{array}$ & $\begin{array}{c}1.530 \mathrm{Aa} \\
(250)\end{array}$ & $\begin{array}{l}1.090 \\
(145)\end{array}$ \\
\hline 50 & $\begin{array}{l}\text { 710Aa } \\
(250)\end{array}$ & $\begin{array}{c}710 \mathrm{Bb} \\
(250)\end{array}$ & $\begin{array}{c}710 \\
(145)\end{array}$ \\
\hline Média & $\begin{array}{l}680 \mathrm{~A} \\
(290)\end{array}$ & $\begin{array}{c}1.120 \mathrm{~A} \\
(290)\end{array}$ & $\begin{array}{c}900 \mathrm{C}^{\prime} \\
(125)\end{array}$ \\
\hline \multicolumn{4}{|c|}{ Primavera } \\
\hline 30 & $\begin{array}{c}1.430 \mathrm{Aa} \\
(330)\end{array}$ & $\begin{array}{c}860 \mathrm{Ab} \\
(330)\end{array}$ & $\begin{array}{l}1.150 \\
(196)\end{array}$ \\
\hline 50 & $\begin{array}{c}1.480 \mathrm{Ba} \\
(330)\end{array}$ & $\begin{array}{c}2.330 \mathrm{Aa} \\
(330)\end{array}$ & $\begin{array}{l}1.900 \\
(196)\end{array}$ \\
\hline Média & $\begin{array}{c}1.460 \mathrm{~A} \\
(240)\end{array}$ & $\begin{array}{c}1.600 \mathrm{~A} \\
(240)\end{array}$ & $\begin{array}{c}1.530 \mathrm{~B}^{\prime} \\
(165)\end{array}$ \\
\hline
\end{tabular}

Números entre parênteses correspondem ao erro padrão da média.

Médias na mesma coluna seguidas de mesma letra minúscula não diferem entre si $(\mathrm{P}>0,10)$.

Médias na mesma linha seguidas de mesma letra maiúscula não diferem entre si $(P>0,10)$.

Médias de época do ano seguidas de mesma letra maiúscula acrescidas de (") não diferem entre si $(\mathrm{P}>0,10)$. 


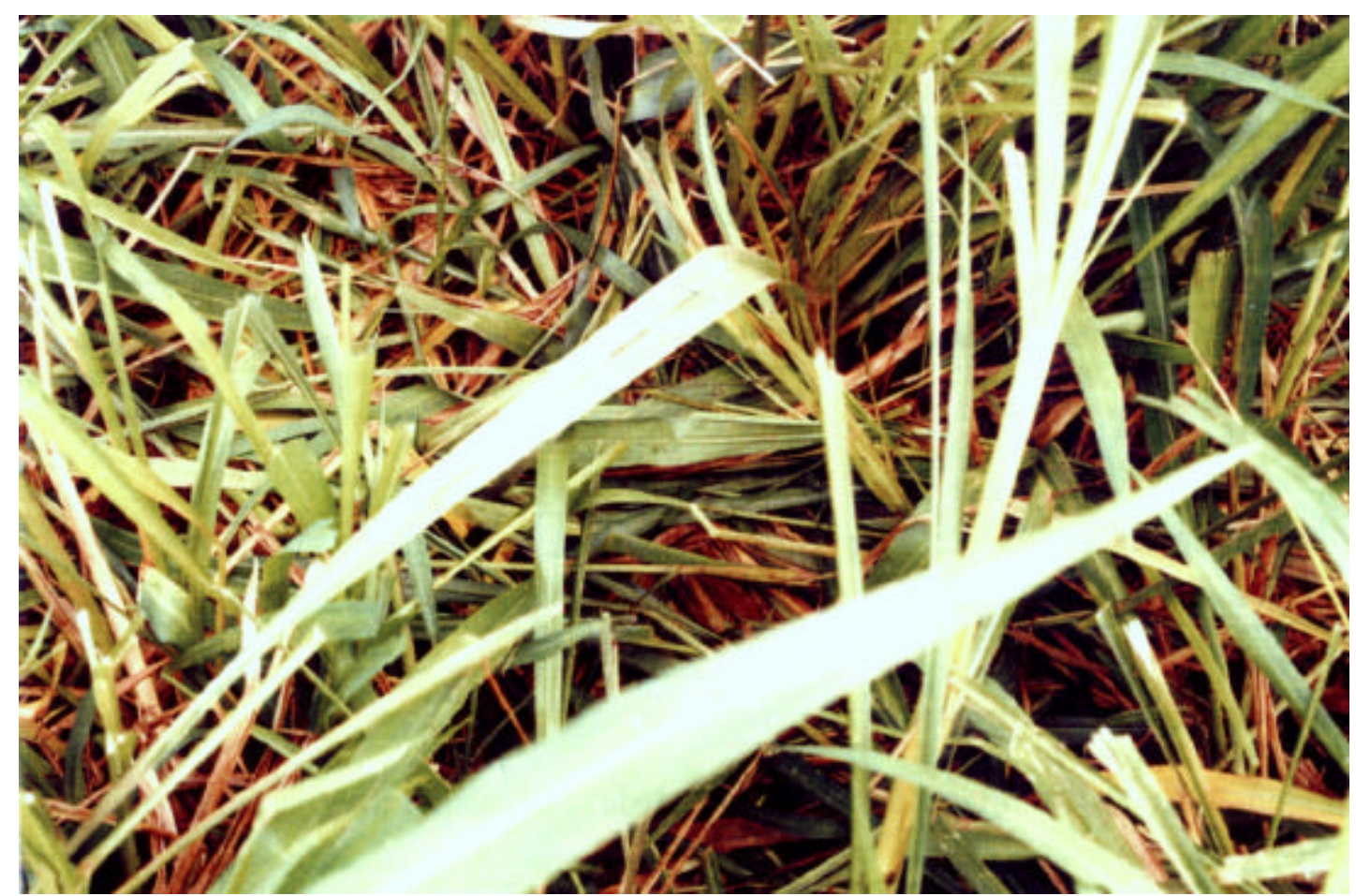

Figura 30- Perdas por pastejo observadas no campo para o tratamento 50/100

Além do aspecto quantitativo é importante conhecer a composição da forragem perdida. Os tratamentos de $100 \%$ de IL apresentaram uma maior proporção de hastes nas perdas (Tabela 64). Não houve diferença $(\mathrm{P}>0,10)$ para a proporção de hastes nos tratamentos de $95 \%$ de $\mathrm{IL}$ ao longo do ano, com os valores médios oscilando em torno de $12 \%$. A maior oscilação ocorreu para os tratamentos de 100\% de IL (11 a 20\%), com a maior proporção de hastes tendo sido observada no verão (20\%). Os tratamentos que apresentaram maior proporção de folhas nas perdas por pastejo foram 30/95 e 50/100 (Tabela 65). 
Tabela 64. Proporção de hastes (\%) nas perdas de forragem durante o pastejo de capimMombaça para os tratamentos de 95 e $100 \%$ de interceptação luminosa nas épocas do ano

\begin{tabular}{ccccc}
\hline $\begin{array}{c}\text { Interceptação } \\
\text { luminosa (\%) }\end{array}$ & Verão & $\begin{array}{c}\text { Época do ano } \\
\text { Outono/Inverno }\end{array}$ & Primavera & Média \\
\hline 95 & $13,1 \mathrm{Ab}$ & $11,2 \mathrm{Aa}$ & $10,9 \mathrm{Aa}$ & $11,7 \mathrm{~b}$ \\
& $(1,76)$ & $(1,76)$ & $(1,76)$ & $(0,92)$ \\
100 & $20,4 \mathrm{Aa}$ & $14,5 \mathrm{Ba}$ & $10,7 \mathrm{Ba}$ & $15,2 \mathrm{a}$ \\
& $(1,76)$ & $(1,76)$ & $(1,76)$ & $(0,92)$ \\
Média & $16,7 \mathrm{~A}$ & $12,9 \mathrm{~B}$ & $10,8 \mathrm{~B}$ & 13,5 \\
& $(1,24)$ & $(1,24)$ & $(1,24)$ & \\
\hline
\end{tabular}

Números entre parênteses correspondem ao erro padrão da média.

Médias na mesma coluna seguidas de mesma letra minúscula não diferem entre si $(\mathrm{P}>0,10)$.

Médias na mesma linha seguidas de mesma letra maiúscula não diferem entre si $(P>0,10)$.

Tabela 65. Proporção de lâminas foliares (\%) nas perdas de forragem durante o pastejo de capim-Mombaça submetido a regimes de pastejo intermitente

\begin{tabular}{cccc}
\hline $\begin{array}{c}\text { Resíduo } \\
(\mathrm{cm})\end{array}$ & \multicolumn{3}{c}{ Interceptação luminosa (\%) } \\
\hline 30 & $31,6 \mathrm{Aa}$ & 100 & Média \\
\hline \multirow{3}{*}{50} & $(1,92)$ & $24,7 \mathrm{Bb}$ & 28,1 \\
& $25,7 \mathrm{Bb}$ & $(1,92)$ & $(1,36)$ \\
Média & $(1,92)$ & $31,0 \mathrm{Aa}$ & 28,3 \\
& 28,6 & $(1,92)$ & $(1,36)$ \\
& $(1,36)$ & 27,8 & 28,2 \\
\hline
\end{tabular}

Números entre parênteses correspondem ao erro padrão da média.

Médias na mesma coluna seguidas de mesma letra minúscula não diferem entre si $(\mathrm{P}>0,10)$.

Médias na mesma linha seguidas de mesma letra maiúscula não diferem entre si $(P>0,10)$.

Com relação à época do ano, as maiores proporções de folhas nas perdas foram observadas no verão $(31,7 \%)$ e as menores no outono/inverno $(25,7 \%)$ e primavera $(27,2 \%)$. O tratamento 50/100 apresentou a menor proporção de material morto nas perdas, sendo maiores valores registrados para os tratamentos 50/95 e 30/100 (Tabela 66). 
Tabela 66. Proporção de material morto (\%) nas perdas de forragem durante o pastejo de capim-Mombaça submetido a regimes de pastejo intermitente

\begin{tabular}{cccc}
\hline $\begin{array}{c}\text { Resíduo } \\
(\mathrm{cm})\end{array}$ & 95 & Interceptação luminosa (\%) \\
\hline 30 & $55,7 \mathrm{Aa}$ & $59,9 \mathrm{Aa}$ & Média \\
& $(2,95)$ & $(2,95)$ & 57,8 \\
50 & $61,6 \mathrm{Aa}$ & $50,5 \mathrm{Bb}$ & 56,1 \\
& $(2,95)$ & $(2,95)$ & $(2,09)$ \\
Média & 58,7 & 55,2 & 57,0 \\
& $(2,09)$ & $(2,09)$ & \\
\hline
\end{tabular}

Números entre parênteses correspondem ao erro padrão da média.

Médias na mesma coluna seguidas de mesma letra minúscula não diferem entre si $(\mathrm{P}>0,10)$.

Médias na mesma linha seguidas de mesma letra maiúscula não diferem entre si $(P>0,10)$. 


\section{DISCUSSÃO}

\subsection{Características do dossel forrageiro}

A presença de hastes no dossel forrageiro foi o principal fator de modificação da estrutura do pasto. Os tratamentos ou manejos impostos definiram a estrutura do dossel forrageiro no sentido de permitir o controle ou o desenvolvimento de hastes, tanto vegetativas como reprodutivas.

O momento da retirada dos animais foi determinado pela altura do resíduo com a finalidade de manter o controle sobre a estrutura da massa de forragem residual. A quantidade e qualidade da massa de forragem residual são de suma importância para a rebrotação do ciclo de pastejo seguinte. O objetivo de manter a altura do resíduo foi alcançado para os tratamentos de $95 \%$ de IL, nos quais foi possível atingir as metas prédefinidas (30 e $50 \mathrm{~cm}$ ). Contudo, houve aumento da altura do dossel na condição de póspastejo dos tratamentos de $100 \%$ de IL no decorrer dos ciclos de pastejo. Essa elevação da altura do resíduo esteve relacionada ao intenso crescimento de hastes (Tabela 5). Gomes (2001), trabalhando com capim-Mombaça manejado sob diferentes combinações entre intensidades de pastejo (ofertas de 4, 8 e 12\%) e períodos de ocupação (1 e 3 dias) com período de descanso fixo de 35 dias, obteve aumento da altura de resíduo mesmo quando os pastejos foram mais intensos. Para os tratamentos de $95 \%$ de IL, nos quais foram registradas as menores proporções de hastes (Tabela 10), a altura do resíduo foi mantida relativamente constante (Tabela 5), pois os animais não encontravam barreira física significativa (hastes) impedindo ou dificultando o rebaixamento do pasto. Dessa forma, os tratamentos de $95 \%$ de $\mathrm{IL}$ (mais freqüentes) foram mais eficientes que os tratamentos utilizados por Gomes (2001) para o controle efetivo da altura do resíduo. Para os tratamentos de $95 \%$ de IL o intervalo entre pastejos foi de 22 a 24 dias e para os 
tratamentos de $100 \%$ de IL o intervalo variou entre 31 e 35 dias (Figura 11) durante a primavera e verão. Os tratamentos aplicados por Gomes (2001) podem ser comparados aos menos freqüentes, deste experimento, retratados pelos tratamentos de $100 \%$ de IL, por possuírem períodos de descanso semelhantes.

A elevada quantidade de hastes (Tabela 10) associada ao aumento em altura do dossel forrageiro na condição de pós-pastejo (Tabela 5) para os tratamentos de $100 \%$ de IL promoveu um aumento progressivo na massa de forragem (Tabela 8). Já os tratamentos de $95 \%$ de IL, com menores quantidades de hastes, mais finas e flexíveis, propiciaram a remoção de grande quantidade da forragem disponível acima da altura do resíduo durante o pastejo. Dessa forma, como não houve dificuldade em atingir a altura de resíduo pré-definida, a massa de forragem teve menor variação que a massa de forragem dos tratamentos de $100 \%$ de IL. Como conseqüência, a massa de forragem residual desses tratamentos apresentou maior proporção de lâminas foliares (Tabela 9) que os tratamentos de $100 \%$ de IL. Esse fato foi observado durante o ano todo, inclusive no outono/inverno, época de florescimento intenso, crescimento expressivo de hastes e baixo crescimento foliar. Na primavera, época de elevação da disponibilidade dos fatores de crescimento, houve maior rebrotação basal, como verificado por Uebele (2002) em experimento concomitante na mesma área experimental. Essa rebrotação apresentou hastes mais tenras e com entrenós mais curtos, promovendo uma redução na produção de forragem proveniente de hastes.

A ação do pastejo foi responsável pela redução de aproximadamente 20 pontos percentuais da proporção de lâminas foliares da massa de forragem na condição de prépastejo (Tabelas 9 e 13). Houve aumento de 8 a 10 pontos percentuais na proporção de hastes e de 8 a 11 pontos percentuais na proporção de material morto. Brâncio et al. (1996), analisando a composição morfológica de três cultivares de P. maximum sob pastejo, afirmaram que devido à preferênc ia dos animais por folhas (Hodgson, 1990) houve aumento nas proporções de hastes e de material morto e redução na proporção de folhas quando comparados os valores de composição morfológica da massa de forragem em pré e pós-pastejo. Teixeira (1998) também encontrou diminuição na fração de 
lâminas foliares no resíduo pós-pastejo de capim-Tobiatã submetido a pastejo rotacionado com intervalos entre pastejos de 33 dias e período de ocupação de 1 dia.

A proporção de lâminas foliares remanescentes do pastejo e presentes no resíduo variou de 40 a $50 \%$ para os tratamentos de $95 \%$ de IL e de 29 a $37 \%$ para os tratamentos de $100 \%$ de IL. As altas proporções de lâminas foliares podem ter sido superestimadas, já que o corte para determinação foi realizado a $20 \mathrm{~cm}$ de altura do nível do solo, não considerando a estrutura abaixo dessa altura que, provavelmente, era composta por hastes e material morto. Esse fato comprometeria a comparação dos valores absolutos mensurados neste experimento com valores correspondentes relatados na literatura. Entretanto, a comparação entre tratamentos é pertinente e extremamente válida para a avaliação dos objetivos propostos. A diferença de 10 a 20 pontos percentuais na proporção de lâminas foliares entre os tratamentos pode ter sido função de os pastejos mais freqüentes inibirem o alongamento de hastes, propiciando maior presença de folhas na massa de forragem do resíduo. Teixeira (1998) encontrou $16 \%$ de lâminas foliares no resíduo pós-pastejo de capim-Tobiatã manejado com 33 dias de descanso, indicando que, provavelmente, nesse manejo não era possível a sobrevivência de grande quantidade de folhas na base do dossel forrageiro.

O momento do pastejo foi determinado por meio da interceptação luminosa alcançada pelo dossel forrageiro. Contudo, foram avaliadas altura e massa de forragem para que esses parâmetros de recomendação de manejo pudessem vir a, eventualmente, ser utilizados sem a necessidade de monitoramento da interceptação luminosa.

A altura do dossel em pré-pastejo comportourse de forma bastante consistente e homogênea ao longo do ano, sendo correspondente a valores ao redor de $90 \mathrm{~cm}$ para 95\% de IL e de $115 \mathrm{~cm}$ para 100\% de IL (Tabela 7). Esse resultado aponta de forma bastante promissora para a possibilidade de utilização da altura do dossel na condição de pré-pastejo como um parâmetro-guia prático, fácil e confiável para o controle e manejo do pastejo em situações de desfolhação intermitente. No entanto, é importante ressaltar que a determinação da altura deve estar associada a parâmetros fisiológicos e ecofisiológicos das pastagens para que tenha valor como ferramenta de manejo. Houve 
uma forte associação positiva entre os valores de altura e interceptação luminosa do dossel forrageiro (Figura 16).

A maior altura do dossel na condição de pré-pastejo obtida para os tratamentos de $100 \%$ de IL (Tabela 7) foi decorrente do maior intervalo entre pastejos (Figura 11) e maior desenvolvimento de hastes vegetativas (Tabela 13), que elevaram a altura das folhas (Tabela 7). Houve uma pequena elevação da altura durante o outono/inverno (Tabela 6) devido ao intenso florescimento ocorrido naquela época do ano. O florescimento deve ter promovido o distanciamento dos entrenós, que se alongaram mais rapidamente, elevando a altura das folhas e, conseqüentemente, do dossel forrageiro.

A massa de forragem também apresentou padrão de estabilidade para as condições de pré-pastejo registradas durante o período experimental (Tabela 12). Contudo, apesar de confiável, é um parâmetro menos prático, uma vez que sua mensuração não é tão simples quanto à medição de altura em condições de campo. Os valores de massa de forragem registrados a cada pastejo para os tratamentos de $95 \%$ de IL (4.300 a $4.800 \mathrm{~kg} \mathrm{ha}^{-1}$ de MS) foram menores que aqueles dos tratamentos de $100 \%$ de IL (7.300 a $8.900 \mathrm{~kg} \mathrm{ha}^{-1}$ de MS). Santos et al. (1999), em um estudo sobre o efeito da frequiência de corte sobre a massa de forragem de capim-Mombaça, encontrou 5.700, 8.000 e $8.900 \mathrm{~kg} \mathrm{ha}^{-1}$ de MS para os intervalos entre cortes de 28, 38 e 48 dias, respectivamente. Os valores de massa de forragem dos tratamentos menos freqüentes foram semelhantes aos valores mensurados para os tratamentos de $100 \%$ de IL, considerando que estes também apresentaram valores médios de intervalo entre pastejos semelhantes (31 a 40 dias). Já os tratamentos de 95\% de IL foram mais freqüentes que o tratamento de 28 dias de descanso aplicado por Santos et al. (1999), já que apresentaram intervalos entre pastejos mais curtos (22 a 24 dias). Entretanto, apesar de momentaneamente os valores de massa de forragem em cada pastejo terem sido menores para os tratamentos de $95 \%$ de $\mathrm{IL}$, quando considera-se que estes tratamentos apresentaram um maior número de pastejos (Tabela 3) verifica-se que a produção total de forragem em determinado período de tempo foi semelhante àquela dos tratamentos de 100\% de IL (Tabela 58). Além disso, a estrutura do dossel apresentada aos animais era bastante distinta (Tabela 13), uma vez que os tratamentos de $95 \%$ de IL não permitiram 
o crescimento exacerbado de hastes como os tratamentos de $100 \%$ de IL. O tratamento 30/95 destacou-se pela menor produção de hastes e menor morte de tecidos, verificada pela menor proporção de material morto na massa de forragem em relação aos demais tratamentos. Houve destaque, também, para o tratamento 30/100, no qual, apenas pelo aumento de 3 a 4 unidade percentuais em interceptação de luz em relação ao 30/95, foram verificadas alterações de toda a estrutura e resposta do dossel forrageiro. Adicionalmente, o tratamento 30/100 propiciou a menor proporção de folhas e maior proporção de hastes acumuladas do experimento com apenas 38 dias de intervalo entre pastejos, em média (Figura 11). Com intervalo entre pastejos de 33 dias, em média, para o tratamento 50/100, também foi possível observar o efeito da alteração da estrutura do dossel forrageiro por meio do aumento da proporção de hastes e redução na proporção de lâminas foliares. Santos (1997), avaliando três períodos de descanso fixos em 28, 38 e 48 dias em capim-Mombaça e capim-Tanzânia, verificou intenso crescimento de hastes para todos os intervalos entre pastejos estudados. Gomes (2001), ao estudar os efeitos de ofertas de forragem (4, 8 e 12\%) e períodos de ocupação (1 e 3 dias) sobre a composição morfológica da forragem de capim-Mombaça, encontrou aumento da altura média do resíduo em decorrência da presença de hastes que dificultavam o rebaixamento do dossel forrageiro. Pinto et al. (1994), trabalhando com capim-Guiné (P. maximum, Jacq. cv. Guiné), observaram diminuição da relação folha / haste com o avanço da rebrotação. Os intervalos entre pastejos utilizados de 14, 28, 42, 56 e 70 dias proporcionaram relação folha / haste de 1,3;1,2;1,0;0,7 e 0,5, respectivamente. Também Cândido et al. (2003), avaliando o crescimento de hastes em capim-Mombaça submetido ao pastejo após a completa expansão de 2,5; 3,5 e 4,5 folhas surgidas depois do início do período de rebrotação, obtiveram maior controle de hastes quando os pastejos foram mais freqüentes. Em todos os trabalhos citados houve intenso crescimento de hastes consistentemente associado a longos períodos de descanso. No presente experimento, o crescimento de hastes somente foi controlado com alta frequiência e alta intensidade de pastejo. Dessa forma, períodos de descanso muito longos para espécies que apresentam a característica de alongar hastes induzem, inevitavelmente, a um elevado grau de dificuldade em exercer qualquer tipo de controle sobre estrutura do dossel, o que pode 
limitar o crescimento foliar na rebrotação subseqüente e a produção eficiente de forragem.

As proporções de lâminas foliares e hastes foram mais afetadas pelos tratamentos de interceptação luminosa (momento de entrada) do que pelos tratamentos de altura do resíduo (momento da retirada dos animais). Cecato et al. (2000) também não obtiveram diferenças nas proporções de folhas quando aplicadas duas alturas de resíduo (20 e 40 $\mathrm{cm}$ ) e período de descanso fixo de 35 dias em capim-Mombaça.

A proporção de material morto na forragem em oferta na condição de pré-pastejo variou ao redor de 14 a $21 \%$, tendo os tratamentos de pastejos mais frequientes (95\% de IL) as menores proporções. Gomes (2001) também encontrou maiores proporções de material morto em pastos de capim-Mombaça manejados menos freqüentemente. Brâncio et al. (2000), analisando a composição morfológica da forragem em oferta dos capins Tanzânia, Mombaça e Massai, verificaram valores mais elevados de material morto (21 a 54\%) que os obtidos neste experimento.

A composição morfológica do dossel forrageiro afetou o seu IAF (Tabela 16). Tratamentos com maiores proporções de hastes e menores proporções de lâminas foliares (Tabela 13) apresentaram menores índices de área foliar relativamente aos tratamentos com mais folhas. Os valores de IAF cresceram consistentemente durante a rebrotação, atingindo valores semelhantes na condição de pré-pastejo para cada tratamento de interceptação luminosa. Mello (2002), trabalhando com capim-Tanzânia manejado com 33 dias de descanso e três resíduos determinados através de massa residual de folhas $\left(1.000,2.500\right.$ e $4.000 \mathrm{~kg} \mathrm{ha}^{-1}$ de MS), obteve aumento linear de IAF com o decorrer do período de descanso.

Durante a rebrotação, o IAF apresentou alta correlação com a interceptação luminosa já que as duas medições foram realizadas por meio do aparelho analisador de dossel (LAI-2000) (Figura 15). Mello (2002) também relatou comportamento semelhante para o capim-Tanzânia utilizando o mesmo aparelho. Quando foram relacionadas interceptação luminosa e altura do dossel forrageiro, foi detectada uma elevada associação positiva, considerando que as duas variáveis foram mensuradas de maneira independente (Figura 16). A altura do dossel forrageiro em torno de $90 \mathrm{~cm}$ 
correspondeu a uma interceptação luminosa do dossel forrageiro de 95\%, interceptação essa correspondente ao IAF crítico (Donald ${ }^{1}$ ). A partir de $115 \mathrm{~cm}$ de altura do dossel, a interceptação luminosa já era superior a 98\%. Essas relações somente devem ser estabelecidas quando os pastos estiverem sendo manejados com base na interceptação luminosa como determinante da entrada dos animais. Isso porque existe uma adaptação como forma de resposta das plantas aos impactos da desfolhação, numa tentativa de restabelecer e manter um equilíbrio de crescimento quando os recursos são utilizados de maneira balanceada e tendo como finalidade atingir um padrão ótimo de crescimento (Lemaire \& Chapman, 1996). Dessa forma, quando o crescimento e a estrutura do dossel forrageiro não estiverem sendo controlados adequadamente, podem ocorrer distorções nas respostas mensuradas. Como forma de ilustração da adaptação da pastagem ao manejo aplicado, o trabalho de Alexandrino et al. (2003), utilizando o capim-Mombaça manejado sob lotação contínua $(25,50,75,100$ e $125 \mathrm{~cm}$ de altura), revelou que o IAF crítico (atingido quando 95\% da luz incidente é interceptada pelo dossel) ocorreu aos 65 $\mathrm{cm}$ de altura média do dossel, enquanto que quando manejado sob lotação intermitente o IAF crítico mensurado neste experimento ocorreu a uma altura média ao redor de $90 \mathrm{~cm}$.

A elevação dos valores de IAF propiciou aumento na interceptação luminosa e no ângulo da folhagem durante o período de rebrotação. No início da rebrotação tanto a interceptação luminosa como o ângulo da folhagem foram influenciados pela altura do resíduo. Os tratamentos de $30 \mathrm{~cm}$ de resíduo apresentaram menores valores de interceptação luminosa comparativamente aos tratamentos de $50 \mathrm{~cm}$ em decorrência da menor massa de forragem presente naquela condição. Pastos com $30 \mathrm{~cm}$ de resíduo apresentavam estrutura do dossel mais ereta que pastos com $50 \mathrm{~cm}$ de resíduo. Com o decorrer da rebrotação, foi verificado aumento do IAF devido à elevação da massa de lâminas foliares. Essa maior massa de folhas tornou o dossel mais ereto, interceptando mais luz, apesar de as diferenças entre os tratamentos de resíduo ainda permanecerem. $\mathrm{Na}$ fase final de rebrotação, o tratamento com maior proporção de folhas e menor proporção de hastes (30/95) apresentou um dossel mais ereto, interceptando a mesma proporção de luz com IAF semelhante àquele do tratamento 50/95. O tratamento 50/95,

\footnotetext{
${ }^{1}$ Citação no rodapé da página 3.
} 
como já apresentava uma maior proporção de hastes que o 30/95, apresentou um dossel um pouco menos ereto, interceptando a mesma proporção de luz com um IAF semelhante. O aumento de 3 a 4 pontos percentuais em interceptação luminosa do dossel forrageiro na condição de pré-pastejo promoveu aumento de $31 \%$ nos valores de IAF. Além disso, a elevação da interceptação luminosa promoveu uma considerável redução no ângulo da folhagem, determinando um dossel menos ereto devido a maior massa dos perfilhos (Tabela 28). Todos esses eventos são conseqüência do crescimento acelerado de hastes durante o aumento de 3 a 4 unidades percentuais em interceptação luminosa do dossel, dos pastos de $100 \%$ de IL em relação aos de $95 \%$ de IL tornando os perfilhos mais pesados e menos eretos.

A densidade populacional de perfilhos (Tabelas 25, 26 e 27) também foi afetada pela interceptação luminosa no momento da entrada dos animais para o pastejo. No verão, os tratamentos de $95 \%$ de $\mathrm{IL}$ apresentaram aumento no número de perfilhos durante todo o período de rebrotação, enquanto que os tratamentos de $100 \%$ de IL estabilizaram seu número de perfilhos a partir da metade do período de rebrotação (Tabela 25). Provavelmente, a estabilização ocorreu depois que o dossel atingiu 95\% de IL, sendo o número de perfilhos por unidade de área foi crescente até esta condição. Quando o dossel atingiu 95\% de IL, houve intensificação do processo de senescência e morte de tecidos vegetais que passaram a receber luminosidade deficiente chegando à ausência total de luz na proximidade do nível do solo. Dessa forma, perfilhos mais fracos localizados abaixo da densa camada de folhas do dossel forrageiro e que necessitavam que a luz atingisse a base da touceira, passaram a ser sombreados e morreram por não erem condições de competição. De acordo com Carvalho (2002), em experimento analisando a exposição de diferentes partes da planta de capim-Mombaça e capim-Tanzânia a carbono radiativo, o capim-Mombaça apresentou a característica de eliminação rápida de perfilhos velhos, fracos ou não essenciais através de alta translocação dos nutrientes para as outras partes da planta que apresentavam crescimento mais acelerado. No mesmo sentido, analisando a taxa de senescência de hastes (indicação de morte do perfilho) (Tabela 53), verifica-se que houve aceleração da senescência e morte de hastes a partir da metade da rebrotação. A senescência e morte 
ocorreram tanto para os tratamentos de $95 \%$ de IL como para os tratamentos de $100 \%$ de IL, contudo a taxa de senescência para os tratamentos de $100 \%$ de IL foi mais de 5 vezes superior àquela dos tratamentos de 95\% de IL. Além disso, segundo Uebele (2002) em experimento concomitante na mesma área experimental, as taxas de aparecimento de perfilhos foram significativamente maiores para os tratamentos de $95 \%$ de IL $(1,36$ perfilhos 100 perfilhos $^{-1}$ dia $\left.^{-1}\right)$ relativamente aos tratamentos de $100 \%$ de IL $(1,18$ perfilhos 100 perfilhos $^{-1} \mathrm{dia}^{-1}$ ). Essas ocorrências conduzem à inferência de que houve aumento consistente em densidade populacional de perfilhos para os tratamentos de $95 \%$ de IL devido ao maior aparecimento de perfilhos seguido de menor senescência de hastes da metade para o final do período de rebrotação. Já os tratamentos de $100 \%$ de IL apresentaram menores taxas de aparecimento de perfilhos seguidas de maior mortalidade de hastes da metade para o final do período de rebrotação, levando a uma estabilização e até mesmo redução da densidade populacional de perfilhos sob àquelas circunstâncias.

No outono/inverno, época de considerada diminuição na disponibilidade de fatores de crescimento, houve redução da densidade populacional de perfilhos relativamente ao verão (Tabelas 25 e 26). Naquela época, houve aumento do número de perfilhos no início do período de rebrotação, seguido de estabilização e queda no final do período. Esses eventos podem ter estado relacionados ao florescimento, que reduz a diferenciação de gemas para formação de novos perfilhos e à redução na disponibilidade de fatores de crescimento, principalmente temperatura, água e nitrogênio (Langer, 1962). Os tratamentos de $95 \%$ de IL apresentaram redução mais acentuada em densidade populacional de perfilhos que os tratamentos de 100\% de IL (Figura 19), a qual poderia estar relacionada a uma compensação no número de perfilhos dos tratamentos de $95 \%$ de IL em relação à densidade de perfilhos no verão. Na época de menor disponibilidade de luz, os tratamentos com maiores proporções de folhas (95\% de IL) iniciaram o processo de competição antes dos tratamentos de $100 \%$ de IL. Nos tratamentos de $100 \%$ de IL, com maior alongamento de hastes, provavelmente a condição e a disponibilidade de luz no interior do dossel era melhor, diminuindo a competição por luz e, portanto, a necessidade de ajustes entre número e peso por perfilhos. A maior taxa de aparecimento de perfilhos registrada para os tratamentos de $95 \%$ de IL no verão (1,36 perfilhos 100 
perfilhos $\left.{ }^{-1} \mathrm{dia}^{-1}\right)$ não foi mantida durante o outono (0,62 perfilho 100 perfilhos $\left.^{-1} \mathrm{dia}^{-1}\right)$, sendo que, no inverno, o aparecimento de perfilhos foi menor para os tratamentos de 95\% de IL (0,48 perfilho 100 perfilhos $^{-1}$ dia $\left.^{-1}\right)$ comparativamente aos tratamentos de $100 \%$ de IL (0,72 perfilhos 100 perfilhos $\left.^{-1} \mathrm{dia}^{-1}\right)$ (Uebele, 2002). Nesse contexto, o tratamento 50/95 apresentou redução na população de perfilhos do início ao final do período de rebrotação, função da menor taxa de aparecimento de perfilhos durante o outono e inverno (0,48 e 0,39 perfilhos 100 perfilhos $^{-1}$ dia $\left.^{-1}\right)$ (Uebele, 2002) e maior taxa de senescência de hastes (Tabela 53). As taxas de senescência de hastes dos tratamentos de $100 \%$ de IL apresentaram considerável redução do verão para o outono/inverno, enquanto que os tratamentos de $95 \%$ de $\mathrm{IL}$ apresentaram considerável aumento dessa taxa, passando de 1,0 para 4,0 $\mathrm{cm}$ perfilho ${ }^{-1}$ dia $^{-1}$ (Tabela 53). Rego et al. (2001) conduziram um experimento para avaliar o perfilhamento de pastos de capim-Tanzânia mantidos em quatro alturas de dossel forrageiro $(25,45,55$ e $75 \mathrm{~cm})$ e registraram redução no número de perfilhos e estabilização na massa dos perfilhos durante o período de florescimento. Braga (2001) avaliou a morfologia de pastos de capim-Mombaça submetidos a dois intervalos entre cortes ( 28 e 42 dias) e reportou maior número de perfilhos em desenvolvimento reprodutivo (fase de alongamento e florescimento) nos tratamentos com 42 dias de intervalo entre cortes, sendo que esses perfilhos exerceram forte influência sobre a produção e massa de forragem. Assim sendo, há indicação de um efeito do componente haste sobre o ambiente luminoso no interior do dossel forrageiro interferindo sobre o processo de morte de perfilhos dependente de densidade populacional (competição por luz) ou de uma época do ano sobre a outra.

O comportamento da densidade populacional de perfilhos durante a primavera (Tabela 27) foi intermediário em relação àquele do outono/inverno (Tabela 26) e verão (Tabela 25), indicando uma tentativa de aumento na população de perfilhos à medida que os fatores de crescimento iam se tornando mais disponíveis, atingindo um máximo no verão. Na primavera, o tratamento 50/100 apresentou um grande aumento no número de perfilhos (Figura 17). Já para o tratamento 30/100, o aumento em densidade populacional foi mais lento devido à baixa taxa de aparecimento de perfilhos $(0,73$ 
perfilho 100 perfilhos $^{-1}$ dia $^{-1}$ ) (Uebele, 2002) associada à alta taxa de senescência de hastes (Tabela 53).

Associado ao aumento crescente da população de perfilhos, principalmente na época de crescimento (primavera e verão), houve incremento na massa dos perfilhos até que fosse realizado o pastejo (Tabelas 30 e 31). Com capim-Tanzânia em pastejo intermitente, foram relatados aumentos crescentes em densidade populacional e massa dos perfilhos durante a estação de crescimento (Rego et al., 2001). Em todas as condições e épocas do ano houve aumento da massa por perfilho devido ao aparecimento e crescimento de novas folhas e aumento no comprimento de bainhas e hastes. Contudo, como no presente experimento o período de crescimento para cada manejo aplicado foi variável, houve diferenciação da massa dos perfilhos conforme o tratamento. Os perfilhos dos tratamentos de $100 \%$ de IL foram mais pesados que os perfilhos dos tratamentos de $95 \%$ de IL. Esse aumento na massa dos perfilhos foi decorrente do aumento da massa de hastes, já que não houve acréscimo no acúmulo líquido de folhas depois de atingido 95\% de IL (Tabela 57).

\subsection{Produção de forragem}

As taxas de expansão foliar para os tratamentos pastejados com $95 \%$ de IL foram relativamente constantes do início do período de rebrotação até o momento do pastejo, enquanto que para os tratamentos de 100\% de IL houve redução após esse período (95\% de interceptação de luz) (Tabela 32). Já a senescência foliar aumentou lentamente até o dossel atingir 95\% de IL, aumentando consideravelmente até a interceptação de cerca de 98 a $99 \%$ da luz incidente quando da realização dos pastejos nos tratamentos de $100 \%$ de IL (Tabela 38). Provavelmente, esse aumento pode ter sido devido ao aumento da taxa respiratória em relação à taxa fotossintética (Donald ${ }^{1}$ ). Além disso, houve redução no número de folhas em expansão por perfilho quando estes encontravam-se submetidos um maior período de descanso (100\% de IL) (Tabela 35). A redução no número de

\footnotetext{
${ }^{1}$ Citação no rodapé da página 3.
} 
folhas em expansão pode ser consequiência do aumento do comprimento de bainhas sucessivas, atrasando o aparecimento de novas lâminas foliares (Lemaire \& Chapman, 1996). No verão, os tratamentos de $100 \%$ de IL apresentaram maior número de folhas em expansão devido, principalmente, ao tratamento de $30 \mathrm{~cm}$ de resíduo (30/100). Esse maior número de flhas em expansão pode estar relacionado à necessidade de aumento rápido de área foliar, já que o tratamento 30/100 iniciava os ciclos de rebrotação com os valores mais baixos de IAF.

Quando considera-se que os incrementos em crescimento foliar aumentaram segundo taxas decrescentes depois de o dossel atingir 95\% de IL e que as taxas de senescência passaram a ser mais elevadas, presume-se que passa a ser interessante a interrupção da rebrotação por meio do pastejo para que possam ser exploradas as fases em que o crescimento é mais acelerado. Carvalho et al. (2001), analisando o crescimento de cultivares de P. maximum (Mombaça e Tanzânia) sob duas alturas de corte (15 e 30 $\mathrm{cm}$ ), observaram que perfilhos mais velhos apresentavam menores taxas de expansão de folhas. Gomide (2001) realizou um estudo sobre a morfogênese de capim-Mombaça pastejado quando do aparecimento de 2,5; 3,5 e 4,5 folhas expandidas por perfilho. $\mathrm{O}$ autor obteve estabilização das taxas de expansão de folhas depois do aparecimento de 2,5 folhas (tratamento mais freqüente).

A redução das taxas de expansão foliar foi variável ao longo do ano (Tabela 34 ), sendo de $32 \%$ durante o verão, $20 \%$ durante o outono/inverno e de $27 \%$ durante a primavera para todos os tratamentos estudados. As maiores taxas de expansão foliar foram obtidas no verão e na primavera $\left(5,6 \mathrm{~cm}_{\text {perfilho }}{ }^{-1} \mathrm{dia}^{-1}\right)$. Gomide (2001) obteve taxas de expansão de folhas de 8,8 e $3,7 \mathrm{~cm}^{\text {perfilho }}{ }^{-1}$ dia $^{-1}$ durante o segundo e terceiro crescimento, respectivamente, para capim-Mombaça cultivado em vasos. Quando alocados no campo, os mesmos tratamentos apresentaram taxas de expansão de folhas que variaram ao redor de $6,2 \mathrm{~cm}$ perfilho ${ }^{-1} \mathrm{dia}^{-1}$. Carvalho (2002) encontrou, em casa de vegetação, valores de taxa de expansão foliar da ordem de 6,9 a $7,3 \mathrm{~cm}$ perfilho- ${ }^{-1}$ dia $^{-1}$ para o capim-Mombaça cortado a 15 e $30 \mathrm{~cm}$ de altura.

A redução da taxa de expansão foliar ao longo da rebrotação foi acompanhada da redução do número de folhas em expansão, porém não foram observadas diferenças 
nas taxas de aparecimento de folhas, fato esse que pode estar relacionado ao comprimento da lâmina foliar. As taxas de aparecimento variaram de 0,055 a 0,070 folha perfilho ${ }^{-1}$ dia $^{-1}$ no período das águas. Gomide (2001) encontrou valores da ordem de 0,095 folha perfilho ${ }^{-1}$ dia $^{-1}$ em condições de campo e de 0,100 a 0,050 folha perfilho $^{-1}$ $\mathrm{dia}^{-1}$ em condições controladas (vasos) para os pastos com crescimento interrompido quando apareciam 2,5; 3,5 e 4,5 folhas expandidas por perfilho. Barbosa et al. (2001) encontraram 0,150 folha perfilho ${ }^{-1}$ dia $^{-1}$ para resíduos mais altos $\left(3,6 \mathrm{t} \mathrm{MS} \mathrm{ha}^{-1}\right)$ e de 0,170 folha perfilho ${ }^{-1}$ dia $^{-1}$ para resíduos mais baixos (2,3 $\left.\mathrm{t} \mathrm{MS} \mathrm{ha}^{-1}\right)$, ambos para capimMombaça submetido a lotação intermitente com 35 dias de descanso. Carvalho (2002) encontrou taxas de aparecimento de folhas de 0,247 a 0,107 folha perfilho ${ }^{-1}$ dia $^{-1}$ para cortes a 15 e $30 \mathrm{~cm}$ de altura em capim-Mombaça sob condições controladas em casa de vegetação. As menores taxas de aparecimento de folhas registradas neste este experimento podem estar relacionadas ao fato de as doses de $\mathrm{N}$ aplicadas terem sido menores que aquelas utilizadas nos estudos citados.

O filocrono obtido na estação de crescimento foi de 13 a 17 dias folha $^{-1}$ perfilho $^{-1}$ para $95 \%$ de IL e de 16 a 19 dias folha ${ }^{-1}$ perfilho $^{-1}$ para $100 \%$ de IL. Essa necessidade de maior número de dias para aparecimento de uma nova folha pode estar relacionada ao maior comprimento das bainhas e hastes para os pastos de $100 \%$ de IL (Lemaire \& Chapman, 1996). No outono/inverno a variação foi de 45 a 51 dias folha ${ }^{-1}$

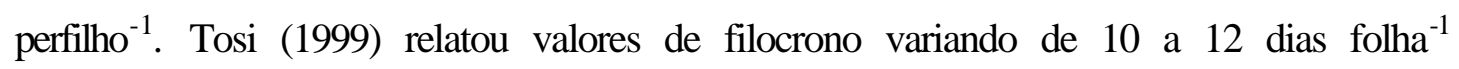
perfilho $^{-1}$ no verão e de 55 dias folha $^{-1}$ perfilho $^{-1}$ no inverno para capim-Tanzânia. Para $B$. brizantha cv. marandu sob lotação contínua (alturas mantidas a 10, 20, 30, $40 \mathrm{~cm}$ ), o filocrono variou de 9 a 11 dias folha $^{-1}$ perfilho $^{-1}$ durante o período de novembro de 2001 a fevereiro de 2002 (Gonçalves, 2002). Ambos os capins citados (Tanzânia e Marandu) apresentaram valores menores de filocrono em relação aos registrados neste estudo, provavelmente devido ao menor comprimento de suas lâminas e bainhas foliares em relação ao capim-Mombaça.

Associado ao processo de crescimento foliar está o processo de senescência foliar. No início do período de rebrotação, com o dossel aberto e bem iluminado (50 a $60 \%$ de IL) (Tabela 22), as taxas de senescência foram baixas e semelhantes entre todos 
os tratamentos avaliados (Tabela 38). Com o avanço do período de rebrotação, as taxas de senescência de folhas dos tratamentos de $100 \%$ de IL superaram em 110 e $122 \%$ as taxas dos tratamentos de $95 \%$ de IL, na metade e no final do período de rebrotação, respectivamente. O aumento das taxas de senescência foi de $366 \%$ do início para o final do período de rebrotação quando os pastos atingiam $100 \%$ de IL, enquanto que os pastejos realizados com 95\% de IL proporcionavam 173\% de aumento em senescência. Isso significa que o aumento de 193 pontos percentuais (173 para 366\%) ocorreu durante o período de elevação de 3 a 4 unidades percentuais na interceptação luminosa do dossel para realização dos pastejos, revelando uma elevada ineficiência de colheita de forragem para os tratamentos com maior intervalo entre pastejos (100\% de IL), independentemente das alturas de resíduo estudadas.

O aumento da taxa de senescência foliar (Tabela 38), redução da taxa de crescimento das folhas (Tabela 32), redução no número de folhas em expansão (Tabela 35) e aumento do número de folhas em senescência e mortas (Tabela 41) afetaram o número de folhas vivas por perfilho, que sofreu redução de 0,5 folha perfilho ${ }^{-1}$ (Tabela 39). O número de folhas vivas variou de 3,9 a 4,9 folhas perfilho ${ }^{-1}$ durante a estação de crescimento. Carvalho (2002) encontrou de 3 a 4 folhas vivas por perfilho em capimMombaça cortado a 15 e $30 \mathrm{~cm}$. Em capim-Marandu, Gonçalves (2002) encontrou 4,5 folhas vivas perfilho- ${ }^{-1}$ quando os pastos foram manejados sob lotação contínua em quatro alturas de dossel $(10,20,30$ e $40 \mathrm{~cm})$ durante o período de novembro de 2001 a fevereiro de 2002.

Relacionando o crescimento com a senescência foliar obtém-se o acúmulo líquido de folhas. Quando o processo de acúmulo líquido é analisado entre os tratamentos de 95 e $100 \%$ de IL, verifica-se que não houve diferença para a média dos pastejos estudados, ou seja, apesar dos tratamentos de $100 \%$ de IL permanecerem por um maior período de tempo em crescimento (maior período de descanso), não houve aumento no acúmulo de folhas verdes por pastejo (Tabela 44). Esse maior período de tempo no campo teve consequiência sobre o número de pastejos durante o ano, sendo este inferior ao número de pastejos realizados nos tratamentos de $95 \%$ de IL. Assim, os tratamentos pastejados com $95 \%$ de IL foram mais eficientes em produção e colheita, 
pois ofertaram maiores quantidades de forragem na somatória dos pastejos (Tabela 58) e não buve perdas expressivas de folhas verdes por senescência. Durante o período seco, a ineficiência dos tratamentos de $100 \%$ de IL tornourse ainda mais evidente, pois houve acúmulo negativo de folhas devido ao processo de senescência foliar superar o processo de crescimento. Apesar de pequeno, o acúmulo líquido de folhas no período seco foi positivo para os tratamentos de $95 \%$ de IL, fazendo com que a produção de forragem se estendesse por mais tempo após o período de florescimento.

Os tratamentos de resíduo $50 \mathrm{~cm}$ foram os responsáveis pelo acúmulo negativo de lâminas foliares ocorrido durante o outono/inverno (Tabela 46). Esse fato pode ter sido consequiência da decomposição da massa de forragem senescida e morta acumulada durante a estação de crescimento (primavera e verão) que, possivelmente, estava estocada no resíduo mais alto. A verificação desse evento pode ser feita por meio do número médio de folhas expandidas por perfilho existente sob aquelas circunstâncias (Tabela 47). O número de folhas expandidas por perfilho nos tratamentos de resíduo 50 $\mathrm{cm}\left(3,4\right.$ folhas perfilho $\left.{ }^{-1}\right)$ foi maior que aquele dos tratamentos de resíduo de $30 \mathrm{~cm}(2,8$ folhas perfilho ${ }^{-1}$ ) na fase final do processo de rebrotação (Tabela 47). No outono/inverno, houve uma redução para 2,8 folhas expandidas por perfilho. Os tratamentos de $30 \mathrm{~cm}$ de resíduo já apresentavam um valor médio de 2,8 folhas por perfilho, enquanto que os pastos dos tratamentos de $50 \mathrm{~cm}$ devem ter sofrido redução no número de folhas expandidas por perfilhos através da senescência e morte das folhas excedentes, atingindo assim, a média obtida no período seco.

Quando considerado o número de pastejos (Tabela 3), o acúmulo líquido das lâminas foliares foi positivo até $95 \%$ de IL não tendo havido incremento na produção de folhas a partir desse ponto (Figuras 25 e 26), uma vez as taxas de senescência e morte de folhas superaram as taxas de crescimento. De acordo com Donald ${ }^{1}$, quando o IAF crítico do dossel é atingido, há sombreamento das folhas inferiores e com isso redução de sua atividade fotossintética, entrando o mesmo em ponto de compensação. O IAF crítico corresponde a $95 \%$ de $\mathrm{IL}$ do dossel, momento em que a taxa média de acúmulo de massa seca do pasto atinge valores máximos. Aumentos subseqüientes em índices de área foliar

\footnotetext{
${ }^{1}$ Citação no rodapé da página 3.
} 
reduzem a taxa de acúmulo do pasto em função do aumento nas taxas de respiração, resultantes de um aumento na quantidade de tecidos sem função fotossintética (senescentes). Esse evento foi descrito para azevém perene por Parsons et al. (1988) e corroborado pelos resultados do presente estudo.

Durante a fase de aumento da interceptação luminosa de 95\% para 98-99\% foi verificada baixa eficiência tanto no processo de acúmulo líquido de folhas como no controle do crescimento de hastes. Plantas de clima tropical, em geral, apresentam alongamento de hastes durante a estação de crescimento (Da Silva \& Pedreira, 1997). O acúmulo de hastes no dossel forrageiro é, na grande maioria das vezes, indesejável, pois há gasto de energia para o crescimento e manutenção dessa fração que, além de dificultar o rebaixamento adequado e uniforme do pasto através do pastejo, influencia negativamente o valor nutritivo da forragem produzida. $\mathrm{O}$ estudo da dinâmica do acúmulo de hastes visa permitir o conhecimento do processo e possibilitar a realização de inferências acerca de maneiras de controlá-lo por meio do manejo do pastejo.

As taxas de alongamento de hastes para os tratamentos de $100 \%$ de IL no início do período de rebrotação foram 2,7 vezes maiores relativamente aos tratamentos de $95 \%$ de IL (Tabela 48). Ao final do período, as taxas de alongamento de hastes dos tratamentos de $100 \%$ de IL permaneceram ainda 2,0 vezes superiores às taxas obtidas para os tratamentos de $95 \%$ de IL. Dessa forma, quando considera-se a massa de hastes acumulada por pastejo para 100\% de IL (Tabela 3), o acréscimo em hastes e bainhas foi 3,0 vezes superior ao acréscimo medido para os tratamentos de 95\% de IL (Tabela 49). Gomide (2001) obteve crescimento de hastes de 0,05 a $0,65 \mathrm{~cm}_{\text {perfilho }}{ }^{-1}$ dia $^{-1}$ do início do primeiro crescimento até o corte para capim-Mombaça. Já no segundo crescimento, as taxas foram de 0,18 para $1,09 \mathrm{~cm}^{\text {perfilho }}{ }^{-1} \mathrm{dia}^{-1}$ do início para o final do período de descanso, que variou de 37 a 43 dias. As taxas de alongamento de hastes para os tratamentos de $95 \%$ de IL foram de 0,10 a $0,24 \mathrm{~cm}_{\text {perfilho }}{ }^{-1}$ dia $^{-1}$ e para os tratamentos de $100 \%$ de IL foram de 0,24 a $0,42 \mathrm{~cm}_{\text {perfilho }}{ }^{-1} \mathrm{dia}^{-1}$, do início para o final do período de rebrotação. Apesar do elevado crescimento de hastes nos tratamentos de $100 \%$ de IL, os valores foram inferiores àqueles relatados por Gomide (2001), pois os períodos de descanso utilizados por esse autor foram maiores que os utilizados neste estudo, 
demonstrando o potencial do capim-Mombaça em produzir hastes quando em crescimento livre ou submetidos a períodos de descanso muito longos.

Com o florescimento no outono/inverno, o alongamento de hastes tornou-se mais acentuado (Tabela 56). Quando o pastejo foi realizado com 95\% de IL (mais freqüentemente), houve considerável redução no florescimento e na espessura das hastes que floresceram em relação aos tratamentos de 100\% de IL (Figuras 12 e 13). Com a entrada da primavera e aumento na disponibilidade dos fatores de crescimento, houve intensa brotação basal e morte das hastes que floresceram nas estações anteriores (Uebele, 2002). Os perfilhos jovens e basais que apareceram durante a primavera apresentaram taxas de alongamento de hastes inferiores às registradas nas outras estações do ano. Ainda que este evento tenha ocorrido em todos os tratamentos durante a primavera, o alongamento de hastes dos tratamentos de $100 \%$ de IL foi superior ao alongamento dos tratamentos de $95 \%$ de IL. Paiva et al. (2001), trabalhando com dois períodos de descanso (28 e 35 dias) associados a três níveis de oferta de forragem (4, 8 e $12 \%$ ) em capim-Mombaça, também encontraram maior crescimento de hastes nos pastos que permaneceram por maior período de tempo em rebrotação. Pastos com 28 dias de crescimento apresentaram maior controle do crescimento de hastes que pastos com 35 dias de rebrotação. Gomide (2001) encontrou diferenças expressivas entre o acúmulo de hastes do primeiro crescimento (690 $\mathrm{kg} \mathrm{ha}^{-1}$ de MS) para o segundo crescimento (2.064 $\mathrm{kg} \mathrm{ha}^{-1}$ de MS) de capim-Mombaça, demonstrando que a planta necessita de um período de tempo para se adaptar quando submetida a um manejo de desfolhação específico.

O acúmulo líquido somente é conhecido quando é considerada a porção negativa da equação (senescência de hastes e encurtamento de bainhas foliares). $\mathrm{O}$ encurtamento de hastes foi registrado em todos os tratamentos, porém em grau variável de intensidade de ocorrência. A primavera foi a época de maior encurtamento de bainhas, principalmente para os tratamentos de 95\% de IL (Tabela 54). Esse fato pode estar associado ao maior alongamento de hastes ocorrido durante o outono/inverno. No decorrer do período de rebrotação durante os ciclos da primavera, houve diminuição do encurtamento das bainhas foliares, podendo este estar relacionado ao aparecimento dos perfilhos jovens e basais naquela época do ano (Uebele, 2002). O encurtamento das 
bainhas ocorreu, provavelmente, como uma forma de resposta dos perfilhos aos tratamentos de $95 \%$ de $\mathrm{IL}$ que foram desfolhados em intervalos menores, mais freqüentemente, os quais não forneceram condições para houvesse alongamento expressivo de hastes.

O capim-Mombaça apresentou uma alta capacidade de eliminar perfilhos velhos e improdutivos drenando rapidamente seus nutrientes (Carvalho, 2002). Da mesma forma, foram registradas maiores taxas de senescência de hastes durante as épocas de verão e outono/inverno (Tabela 53). No verão, face à alta velocidade de crescimento e intensa competição, sobreviviam apenas os perfilhos mais fortes e vigorosos. No outono/inverno, as altas taxas de senescência de hastes foram relacionadas ao alto florescimento, proporcionando a morte natural dos perfilhos após este fenômeno (Uebele, 2002).

O acúmulo líquido de hastes para os tratamentos de 100\% de IL aumentou demasiadamente durante o período de rebrotação (Tabela 55), pois a velocidade de acréscimo de tecidos formadores de hastes superou consideravelmente a morte e encurtamento das bainhas foliares. Entretanto, para os tratamentos de $95 \%$ de IL o acúmulo líquido de hastes foi negativo durante todo o período de rebrotação, evidenciando a alta plasticidade da planta em adaptar-se à condição de manejo imposta (Figura 26). O diferencial entre 95 e $100 \%$ de IL tornou-se mais evidente quando foi considerado o número de pastejos realizados para cada tratamento no experimento (Figura 27).

Desse modo, quando totaliza-se o crescimento total (hastes + folhas), os tratamentos de $100 \%$ de IL superaram os tratamentos de $95 \%$ de IL em $6.300 \mathrm{~kg} \mathrm{ha}^{-1} \mathrm{de}$ MS (Tabela 57). Porém, estão contabilizados cerca de $8.000 \mathrm{~kg} \mathrm{ha}^{-1}$ de MS de hastes a mais na maior massa acumulada $(100 \%$ de IL), parte indesejável na produção de forragem para pastejo. A massa acumulada de folhas para os tratamentos de $95 \%$ de IL foi $1.400 \mathrm{~kg} \mathrm{ha}^{-1}$ de MS maior que aquela para os tratamentos de $100 \%$ de IL.

Quando o acúmulo líquido foi considerado, a diferença entre os tratamentos de interceptação luminosa diminuiu para $800 \mathrm{~kg} \mathrm{ha}^{-1}$ de MS, em favor dos tratamentos de 
$100 \%$ de IL. Contudo, a diferença no acúmulo líquido de folhas foi em torno de $6.300 \mathrm{~kg}$ $\mathrm{ha}^{-1}$ de MS maior para os tratamentos de 95\% de IL (Tabela 57).

Considerando ainda que todo o material morto foi produzido durante o período de rebrotação, esses tecidos nasceram e/ou permaneceram verdes por um período de tempo e depois senesceram e morreram, principalmente as lâminas foliares. Assim, os tratamentos de $95 \%$ de IL produziram $25.900 \mathrm{~kg} \mathrm{ha}^{-1}$ de MS de lâminas foliares, porém permitiram a senescência e morte de $7.950 \mathrm{~kg} \mathrm{ha}^{-1}$ de MS. Dessa forma, a eficiência de acúmulo de lâminas foliares foi de $69 \%$. Para os tratamentos de $100 \%$ de IL, a produção de lâminas foliares foi de $24.540 \mathrm{~kg} \mathrm{ha}^{-1}$ de MS e permitiram a senescência e morte de $12.920 \mathrm{~kg} \mathrm{ha}^{-1}$ de MS, sendo a eficiência de acúmulo líquido de lâminas foliares de $47 \%$ (Tabela 57). Os tratamentos de $95 \%$ de IL produziram $7.450 \mathrm{~kg} \mathrm{ha}^{-1}$ de MS de hastes e bainhas foliares e perderam $8.590 \mathrm{~kg} \mathrm{ha}^{-1}$ de MS por senescência e morte dos tecidos. Os tratamentos de $100 \%$ de IL apresentaram produção de hastes e bainhas foliares de $15.140 \mathrm{~kg} \mathrm{ha}^{-1}$ de MS, perdendo $9.180 \mathrm{~kg} \mathrm{ha}^{-1}$ de MS (Tabela 57). Dessa forma. a eficiência de acúmulo de hastes foi de $-15 \%$ para os tratamentos de $95 \%$ de IL e de $39,4 \%$ para os tratamentos de $100 \%$ de IL. Esses valores demonstram que manejando os pastos com entrada dos animais em 95\% de IL do dossel forrageiro houve maior eficiência para produção de folhas e maior eficiência para o controle do desenvolvimento de hastes.

$\mathrm{O}$ acúmulo líquido resultante de todo o período de rebrotação obtido pelo método de corte da forragem na condição de pós e pré-pastejo apresentou valores numericamente diferentes aos obtidos pela análise direta de crescimento. Entretanto, a tendência de resposta foi muito semelhante. Os tratamentos de $100 \%$ de IL apresentaram acúmulo semelhante ao dos tratamentos de 95\% de IL (Tabela 58). O tratamento 50/95 foi bastante prejudicado pelo florescimento, já que até o outono/inverno este tratamento apresentava desempenho satisfatório. O tratamento 30/95 foi o que proporcionou a maior massa de forragem acumulada durante o ano (Tabela 13). Como consequiência, de acordo com Bueno (2003) em experimento concomitante na mesma área experimental, a forragem produzida para o tratamento 30/95 apresentou os valores de digestibilidade in vitro’ da matéria orgânica (DIVMO) $(63,3 \%)$ e de proteína bruta (PB) $(14,8 \%)$ mais 
elevados em relação aos outros tratamentos (PB variou de 12,7 a 13,6\% e DIVMO variou de 59,7 a 60,3\%). Cecato et al. (2000) não encontraram diferenças entre produção composição morfológica da forragem para os tratamentos com alturas de resíduo de 20 e $40 \mathrm{~cm}$ e período de descanso de 35 dias em capim-Mombaça. Esse resultado pode estar relacionado ao longo período de descanso ao qual o capim-Mombaça foi submetido nas condições daquele experimento. A maior diferença encontrada por Gomide (2001) foi de $835 \mathrm{~kg} \mathrm{ha}^{-1}$ de MS entre o tratamento com pastejo cujo período de crescimento completo era determinado pelo aparecimento de 2,5 folhas (22.855 $\mathrm{kg} \mathrm{ha}^{-1}$ de MS) e aquele de 4,5 folhas (22.020 kg ha-1 de MS), sendo que o tratamento mais produtivo foi aquele pastejado mais freqüentemente.

A produção de forragem foi semelhante entre os tratamentos durante o verão e outono/inverno (Tabela 59). Durante a primavera, os tratamentos de 95\% de IL apresentaram acúmulo de massa de forragem semelhante ao obtido no outono/inverno, sendo que o tratamento 50/95 foi o responsável pela redução da média. O comportamento do tratamento 50/95 é evidenciado pelos valores de taxa de acúmulo, que foram elevados durante os meses de janeiro a abril (Tabela 60). A partir de maio, com a diminuição dos fatores de crescimento, todos os tratamentos apresentaram redução nas taxas de acúmulo de forragem. Contudo, a partir de novembro, todos os tratamentos apresentaram expressiva elevação nas taxas de acúmulo, exceção feita ao tratamento 50/95.

As maiores taxas de acúmulo foram observadas nos meses de verão (164 kg $\mathrm{ha}^{-1} \mathrm{dia}^{-1}$ de MS) e as menores durante o inverno (15 $\mathrm{kg} \mathrm{ha}^{-1} \mathrm{dia}^{-1} \mathrm{de}$ MS). Tosi (1999) encontrou taxas de acúmulo de forragem da ordem de $180 \mathrm{~kg} \mathrm{ha}^{-1} \mathrm{dia}^{-1} \mathrm{de}$ MS em janeiro e $23 \mathrm{~kg} \mathrm{ha}^{-1} \mathrm{dia}^{-1}$ de MS em agosto/setembro para pastos de capim-Tanzânia manejados sob lotação intermitente com 36 dias de descanso no período das águas e 72 dias de descanso no período seco, com adubação de $400 \mathrm{~kg} \mathrm{ha}^{-1}$ ano $^{-1}$ de nitrogênio.

A eficiência no processo de pastejo não se restringe apenas em determinar a eficiência de acúmulo de massa de forragem e sua composição morfológica. Faz-se necessário conhecer também a eficiência de colheita da forragem produzida. Esta pode ser determinada por meio da quantificação das perdas promovidas pela ação do pastejo. 


\subsection{Perdas de forragem pelo pastejo}

Da massa acumulada nos tratamentos de $30 \mathrm{~cm}$ de resíduo $\left(25.900 \mathrm{~kg} \mathrm{ha}^{-1}\right.$ de MS) (Tabela 59), 85\% foi removida por ocasião do pastejo (Tabela 61). Para os tratamentos de $50 \mathrm{~cm}$ de resíduo, do total de forragem acumulado $\left(19.100 \mathrm{~kg} \mathrm{ha}^{-1}\right.$ de MS, houve remoção de $86 \%$. A remoção de forragem parece ter sido proporcional ao total de forragem acumulada, sendo que nos tratamentos de $30 \mathrm{~cm}$ de resíduo houve maior remoção de forragem $\left(22.470 \mathrm{~kg} \mathrm{ha}^{-1}\right.$ de MS) que nos tratamentos de $50 \mathrm{~cm}(16.840 \mathrm{~kg}$ $\mathrm{ha}^{-1}$ de MS). Para os tratamentos de 95\% de IL houve um acúmulo total de $22.410 \mathrm{~kg}$ $\mathrm{ha}^{-1}$ de MS e remoção de $19.860 \mathrm{~kg} \mathrm{ha}^{-1}$ de MS, resultando na remoção de $89 \%$ da forragem acumulada. Para $100 \%$ de IL, o acúmulo total foi de $22.590 \mathrm{~kg} \mathrm{ha}^{-1}$ de MS e a remoção de $20.460 \mathrm{~kg} \mathrm{ha}^{-1}$ de $\mathrm{MS}$, resultando na remoção de $90 \%$ da forragem acumulada.

Da fração da forragem removida, parte foi perdida por ação do pastejo devido à seleção pelos animais e/ou danos físicos. Os tratamentos de 30 e $50 \mathrm{~cm}$ de resíduo não apresentaram diferenças nas perdas pelo pastejo. Dessa forma, os tratamentos de $30 \mathrm{~cm}$ destacaram-se pelo maior aproveitamento de forragem em função do maior acúmulo de massa. Os tratamentos de $30 \mathrm{~cm}$ sobressaíram-se relativamente aos demais tratamentos por causa do tratamento de $95 \%$ de IL, que proporcionou perdas de forragem inferiores às do tratamento $30 / 100$.

Os tratamentos de $95 \%$ de IL proporcionaram valores totais de perdas de forragem durante o pastejo $60 \%$ inferiores àqueles dos tratamentos de $100 \%$ de $\mathrm{IL}$ (Tabela 62). Considerando os valores de massa de forragem acumulada e removida entre os tratamentos de interceptação luminosa, o aproveitamento da forragem removida para os tratamentos de $95 \%$ de IL foi de $16.550 \mathrm{~kg} \mathrm{ha}^{-1}$ de MS ou $83 \%$ de eficiência de utilização e de $15.180 \mathrm{~kg} \mathrm{ha}^{-1}$ de MS de aproveitamento da forragem removida para os tratamentos de $100 \%$ de IL ou $74 \%$ de eficiência de utilização. A maior eficiência de aproveitamento da forragem esteve relacionada à composição morfológic a da massa de forragem ofertada aos animais. Os tratamentos de 95\% de IL apresentaram maior 
proporção de lâminas foliares e menores proporções de hastes e material morto em relação aos tratamentos de $100 \%$ de IL (Tabela 13), ressaltando-se, principalmente, o tratamento 30/95, que apresentou a maior proporção de lâminas foliares dentre todos os tratamentos avaliados. Gonçalves (2002) obteve maior eficiência de pastejo (82\%) em pastos de capim-Marandu manejados mais intensivamente, cuja lotação contínua mantinha a altura média do dossel forrageiro a 10 e $20 \mathrm{~cm}$ relativamente aos tratamentos mais lenientes (69\%) mantidos a 30 e $40 \mathrm{~cm}$ de altura. Quadros et al. (2001) observaram que pastagens de capim-Mombaça e capim-Tanzânia, que receberam altas quantidades de nitrogênio, apresentaram as maiores quantidades de perdas de forragem por pastejo, principalmente por pisoteio, isso devido ao maior crescimento decorrente de período de descanso fixo com aceleração do crescimento causado pela alta fertilização nitrogenada. De acordo com Gomes (2001), houve aumento nas perdas de forragem por pastejo quando a oferta de forragem foi muito alta (12\%) consequiência do processo de seleção. Por outro lado, Hillesheim (1987) observou que quando se aumentava a pressão de pastejo para que uma grande quantidade de forragem produzida fosse colhida, houve um considerável aumento das perdas por pastejo em capim-Elefante sob lotação intermitente.

Além da quantidade de forragem perdida, é necessário analisar as frações que foram desprezadas. Os tratamentos de $100 \%$ de $\mathrm{IL}$ apresentaram mais hastes na composição das perdas por pastejo (Tabela 64) por produzirem mais hastes (Tabela 13). Os animais exercem seu poder de seleção rejeitando hastes e materiais muito fibrosos (Hassan et al., 1990). O tratamento 50/100 apresentou alta proporção de lâminas foliares nas perdas por pastejo (Tabela 65) devido à grande perda de forragem por tombamento causado pelos animais, somente observado para este manejo. Outro indicativo de que as perdas nesse tratamento não foram por seletividade foi a baixa proporção de material morto (Tabela 66), normalmente rejeitado pelos animais, uma vez que a massa de forragem ofertada continha alta proporção desse componente (Tabela 13). O tratamento 30/95 também apresentou maior proporção de lâminas foliares nas perdas por pastejo, contudo esse manejo apresentou a maior proporção de lâminas foliares na massa de forragem em pré-pastejo relativamente aos demais tratamentos (Tabela 13). 


\subsection{Considerações Finais}

A altura do dossel apresentou alto grau de associação com os valores de interceptação luminosa como determinante da entrada dos animais para o pastejo, podendo ser utilizada como parâmetro-guia no manejo de capim Mombaça.

A altura pós-pastejo (resíduo) foi aumentando no decorrer da estação de crescimento para os tratamentos de $100 \%$ de IL. Para os tratamentos de $95 \%$ de IL a altura do resíduo foi mantida controlada ao redor dos valores previamente estipulados $(30$ e $50 \mathrm{~cm})$.

A presença de hastes foi fator determinante da diferença entre os tratamentos de 95 e $100 \%$ de IL. Os pastos com tratamento de $95 \%$ de IL apresentavam valores de altura de dossel, IAF e massa de forragem por pastejo menores que os tratamentos de $100 \%$ de IL na condição de pré-pastejo. Contudo, o número de pastejos para os tratamentos de $95 \%$ de IL foi maior que aqueles dos tratamentos de $100 \%$ de IL, compensando os menores valores para todas as avaliações citadas.

$\mathrm{O}$ maior número de pastejos foi decorrência do menor intervalo entre desfolhações apresentado pelos tratamentos de $95 \%$ de IL. Um maior período de descanso para os tratamentos de $100 \%$ de IL proporcionou um aumento considerável no crescimento de hastes. Este componente foi o principal determinante da diferença entre os tratamentos de 95 e $100 \%$ de IL quanto ao crescimento e acúmulo de folhas e estrutura do dossel forrageiro.

Os tratamentos de $100 \%$ de IL produziram perfilhos mais pesados que os tratamentos de $95 \%$ de IL, consequiência da alta taxa de alongamento de hastes registrada no final do período de rebrotação daquele tratamento. O tratamento de $95 \%$ de IL não apresentou acúmulo líquido de hastes positivo em função da alta taxa de redução no comprimento das bainhas foliares, evento este mais pronunciado neste tratamento.

$\mathrm{O}$ acúmulo líquido de lâminas foliares também foi afetado pelo atraso na colheita, pois não houve aumento na produção de folhas depois que o dossel atingiu 95\% de IL. Essa estabilização no acúmulo líquido de lâminas foliares foi relacionada à 
redução na taxa de expansão e elevado aumento nas taxas de senescência de folhas depois de atingido $95 \%$ de IL pelo dossel forrageiro.

Assim, pastos com tratamento de 95\% de IL apresentaram maior produção de folhas o que resultou em melhor aproveitamento da forragem e menores perdas por ação do pastejo. A altura de resíduo também teve influência sobre a remoção de forragem. Pastos com tratamento de $30 \mathrm{~cm}$ de resíduo apresentaram maior remoção de forragem que pastos com $50 \mathrm{~cm}$ de resíduo. As perdas decorrentes da ação do pastejo foram semelhantes para os dois resíduos, conseqüentemente, os pastos com $30 \mathrm{~cm}$ proporcionaram melhor aproveitamento da forragem acumulada. 


\section{CONCLUSÕES}

Com base nos resultados deste experimento, as seguintes conclusões foram elaboradas:

- A altura do dossel é um parâmetro de alta confiabilidade para ser utilizado como guia de manejo de pastagens baseado em interceptação luminosa como determinante do ponto de entrada dos animais para o pastejo.

- O tratamento de pastejo com $95 \%$ de interceptação luminosa pelo dossel (ou $90 \mathrm{~cm}$ de altura) e $30 \mathrm{~cm}$ de altura de resíduo foi o que apresentou maior eficiência de produção e colheita de forragem.

- O acúmulo líquido positivo de lâminas foliares foi máximo quando o dossel atingiu $95 \%$ de interceptação luminosa.

- O excesso de hastes presentes no dossel do capim Mombaça pode ser controlado através do manejo do pastejo, particularmente frequiência de desfolhação.

- O ponto de entrada dos animais deve ser fixado com base em parâmetros que exerçam influência sobre a estrutura do dossel (e.g. interceptação luminosa) para que assim os pastos possam ser manipulados conforme a necessidade do sistema de produção (quantidade e qualidade de forragem) de forma objetiva e consistente. 


\section{REFERÊNCIAS BIBLIOGRÁFICAS}

ALEXANDRINO, E.; GOMIDE, J.A.; CÂNDIDO, M.J.D. Características morfogênicas e estruturais do capim-Mombaça mantido sob diferentes alturas.(compact disc). In: REUNIÃO ANUAL DA SOCIEDADE BRASILEIRA DE ZOOTECNIA, 40., Santa Maria, 2003. Anais. Santa Maria: SBZ, 2003.

BARBOSA, M.A.A.F.; CECATO, U.; ONORATO, W.M.; COELHO, E.M. Estudo do perfilhamento do capim-Mombaça (Panicum maximum Jacq.) (compact disc). In: REUNIÃO ANUAL DA SOCIEDADE BRASILEIRA DE ZOOTECNIA, 34., Juiz de Fora, 1997. Anais. Juiz de Fora: SBZ, 1997.

BARBOSA, M.A.A.F.; DAMASCENO, J.C.; CECATO, U.; SAKAGUTI, E..S. Estudo de perfilhamento em 4 cultivares de Panicum maximum Jacq. submetidos à duas alturas de corte. In: REUNIÃO ANUAL DA SOCIEDADE BRASILEIRA DE ZOOTECNIA, 33., Fortaleza, 1996, Anais. Fortaleza: SBZ, 1996. p. 109-111.

BARBOSA, R.A.; EUCLIDES, V.P.B.; NASCIMENTO Jr, D.; REGAZZO, A.J.; FONSECA, D.M.; GOES, R.H.T.B. Morfogênese do capim tanzânia em duas intensidades de pastejo. In. REUNIÃO ANUAL DA SOCIEDADE BRASILEIRA DE ZOOTECNIA, 38,. Piracicaba, 2001. Anais. Piracicaba SBZ, 2001. p. 95-96.

BRAGA, G.J. Resposta do capim-Mombaça (Panicum maximum Jacq.) a diferentes doses de nitrogênio e intervalos de corte. Pirassununga, 2001. 122p. Dissertação (Mestrado) - Faculdade de Zootecnia e Engenharia de Alimentos, Universidade de São Paulo. 
BRÂNCIO, P.A.; EUCLIDES, V.P.B.; NASCIMENTO JÚNIOR, D. Avaliação de três cultivares de Panicum maximum Jacq. sob pastejo. 2. Proporções de folha, talo e material morto da pastagem e seletividade em pastejo (compact disc). In. REUNIÃO ANUAL DA SOCIEDADE BRASILEIRA DE ZOOTECNIA, 37., Viçosa, 2000. Anais. Viçosa: SBZ, 2000.

BROUGHAM, R.W. A study in rate of pasture growth Australian Journal of Agricultural Research, v. 6, p. 804-812, 1955.

BROUGHAM, R.W. Effect of intensity of defoliation on regrowth of pasture. Australian Journal of Agricultural Research, v. 7, n. 2, p. 377-387, 1956.

BROUGHAM, R.W. Interception of light by the foliage of pure and mixed stands of pasture plants. Australian Journal of Agricultural Research v.9, p. 39-52, 1957.

BROUGHAM, R.W. The effects of frequency and intensity of grazing on the productivity of productivity of a pasture of short-rotation ryegrass and red and white clover. New Zealand Journal of Agricultural Resarch, v. 2, p. 1232-1248, 1959.

BROUGHAM, R.W. The effects of frequent hard grazing at different times of the year on the productivity and species yields of a grass-clover pastures. New Zealand Journal of Agricultural Research, v. 3, p.125-136, 1960. 
BUENO, A.A.O. Características estruturais do dossel forrageiro, valor nutritivo e produção de forragem em pastos de capim-Mombaça submetidos a regimes de lotação intermitente. Piracicaba, 2003. 124 p. Dissertação (Mestrado) - Escola Superior de Agricultura “Luiz de Queiroz”, Universidade de São Paulo.

CÂNDIDO, M.J.D.; ALEXANDRINO, E.; GOMIDE, J.A. Análise de crescimento em Panicum maximum cv. Mombaça sob condições de campo (compact disc). In: REUNIÃO ANUAL DA SOCIEDADE BRASILEIRA DE ZOOTECNIA, 40., Santa Maria, 2003. Anais. Santa Maria: SBZ, 2003.

CARNEVALLI, R.A.; DA SILVA, S.C. Validação de técnicas experimentais para avaliação de características agronômicas e ecológicas de pastagens de Cynodon spp cv. Coastcross -1. Scientia Agricola, v.56, n.2, p.489-499, abr./jun. 1999.

CARVALHO, D.D. Leaf morphogenesis and tillering behaviour in single plants and simulated swards of Guinea grass (Panicum maximum Jacq.) cultivars. Palmestron North, 2002. p. 155p. Thesis (Ph.D)-Massey University/New Zealand.

CARVALHO, D.D.; MATHEW, C.; HODGSON, J.. Effect of aging in tillers of Panicum maximum on leaf elongation rate. In: INTERNATIONAL GRASSLANDS CONGRESS, 19, São Pedro, 2001. Proceedings. Piracicaba: FEALQ , 2001. p.41. 2001.

CECATO, U.; MACHADO, A.O.; MARTINS, E.N.; PEREIRA, L.A.F.; BARBOSA, M.AAF.; SANTOS, G.T. Avaliação da produção e de algumas características de rebrota de cultivares e acessos de Panicum maximum Jacq. sob duas alturas de corte.

Revista Brasileira de Zootecnia, v.29, n.3, p. 660-668, 2000. 
CHAPMAN, D.F.; LEMAIRE, G. Morphogenic and structural determinants of plant regrowth after defoliation. INTERNATIONAL GRASSLAND CONGRESS, 17, Palmestron North, 1993. Proceeding. Palmestron North: Massey University, 1993. p. 93-104.

CORSI, M.; SANTOS, P.M. Potencial de produção do Panicum maximum. In: SIMPÓSIO SOBRE MANEJO DA PASTAGEM, 11., Piracicaba, 1995. Anais. Piracicaba: FEALQ, 1995. p. 275-304.

DA SILVA, S.C.; PEDREIRA, C.G.S. Princípios de ecologia aplicados ao manejo das pastagens. In: SIMPÓSIO SOBRE ECOSSISTEMAS DE PASTAGENS, 3., Jaboticabal, 1997. Anais, UNESP: Jaboticabal, 1997. p. 1-62.

EMPRESA BRASILEIRA DE PESQUISA AGROPECUÁRIA. Serviço Nacional de Levantamento e Conservação de Solos. Sistema brasileiro de classificação de solos. Brasília: EMBRAPA Produção e Informação, 1999. 412 p.

FAGUNDES, J.L.; DA SILVA, S.C.; PEDREIRA, C.G.S.; CARNEVALLI, R.A.; CARVALHO, C.A.B.; SBRISSIA, A.F. \& PINTO, L.F.M.. Avaliação do índice de área foliar, coeficiente de extinção luminosa e acúmulo de forragem em pastagens de Cynodon spp. sob lotação contínua. Pesquisa Agropecuária Brasileira, v. 36, n. 1, p.187-195, 2001.

FAGUNDES, J.L.; DA SILVA, S.C.; PEDREIRA, C.G.S.; SBRISSIA, A.F.; CARNEVALLI, R.A.; CARVALHO, C.A.B. \& PINTO, L.F.M.. Índice de área foliar, interceptação luminosa e acúmulo de forragem em pastagens de Cynodon spp. sob diferentes intensidades de pastejo. Scientia Agricola, v.56, n. 4, p. 1141-1150, 1999. Suplemento 
GOMES, M.A. Efeitos de intensidades de pastejo e períodos de ocupação da pastagem na massa de forragem e nas perdas e valor nutritivo da matéria seca do capimmombaça (Panicum maximum Jacq. cv. Mombaça). Pirassununga, 200193 p. Dissertação (Mestrado)-Faculdade de Zootecnia e Engenharia de Alimentos, Universidade de São Paulo.

GOMIDE, C.A.M. Características morfofisiológicas associadas ao manejo do capimmombaça (Panicum maximum jacq.) Viçosa, 2001. 107p. Tese (Doutorado)Universidade Federal de Viçosa.

GONÇALVES, A. C. Características morfogênicas e padrões de desfolhação em pastos de capim marandu submetidos a regimes de lotação contínua. Piracicaba, 2002. 124p. Dissertação (Mestrado)-Escola Superior de Agricultura "Luiz de Queiroz". Universidade de São Paulo.

HASSAN, W.E.W.; PHIPPS, R.H.; OWEN, E. Dry matter yield and nutritive value of improved pastures species in Malaysia. Tropical Agriculture, v.67, n.4, p.303-308, 1990.

HERLING, V.R.; JANTALIA, C.P.; PIAZZA, C.; SUDA, C.H.; LUZ, P.H.C.; LIMA, C.G. Determinação da matéria seca disponível do capim Mombaça (Panicum maximum Jacq. cv. Mombaça) sob pastejo. In: REUNIÃO ANUAL DA SOCIEDADE BRASILEIRA DE ZOOTECNIA, 35., Botucatu, 1998. Anais. Botucatu, SBZ, 1998a. p.530-532.

HERLING, V.R.; JANTALIA, C.P.; PIAZZA, C.; SUDA, C.H.; LUZ, P.H.C.; LIMA, C.G. Fisiologia do perfilhamento do capim Mombaça (Panicum maximum Jacq.) sob pastejo. In: REUNIÃO ANUAL DA SOCIEDADE BRASILEIRA DE ZOOTECNIA, 35., Botucatu, 1998. Anais. Botucatu, SBZ, 1998b. p.533-535. 
HERLING, V.R.; PIAZZA, C.; JANTALIA, C.P.; SUDA, C.H.; LUZ, P.H.C.; LIMA, C.G. Efeito do período de descanso e da matéria seca residual no capim Mombaça (Panicum maximum Jacq. ) 2. Perdas de matéria seca. In: REUNIÃO ANUAL DA SOCIEDADE BRASILEIRA DE ZOOTECNIA, 35., Botucatu, 1998. Anais. Botucatu, SBZ, 1998c. p.321-323.

HILLESHEIM, A. Fatores que afetam o consumo e perdas de capim-elefante (Pennisetum purpureum, schum) sob pastejo. Scientia Agricola, v. 59, n.3, p. 427433, jul./set. 2002.

HODGSON, J. Grazing management: science into practice. Massey University: Longman Scientific \& Technical, 1990. 203 p.

HODGSON, J.; BIRCHAM, J.S.; GRANT, S.A.; KING, J. The influence of cutting and grazing management on herbage growth and utilization. In : WRIGHT, C.E., Plant physiology and herbage production. Massey University: British Grassland Society, 1981, p. 51-62.

JANK, M.B. Potencial do gênero Panicum. In: SIMPÓSIO BRASILEIRO DE FORRAGEIRAS E PASTAGENS, Campinas, 1994. Anais. Campinas: Comissão Brasileira de Nutrição Animal, 1994. p.25-31.

KORTE, C.J.; WATKIN, B.R.; HARRIS,W. Use of residual leaf area index and light interception as criteria for spring-grazing management of a ryegrass-dominant pasture. New Zealand Journal of Agricultural Research, v. 25, p. 309-319, 1982.

LANGER, R.H.M. Growth and nutrition of Timothy (Phleum pratense). I. Life history of individual tillers. Annals of Applied Biology, v.44, p. 166-187, 1956.

LANGER, R.H.M. How grasses grow. 2. ed. London: Edward Arnold, 1979. 66p. 
LEMAIRE, G.; CHAPMAN, D. Tissue flows in grazed plant communities. In: HODGSON, J.; ILLIUS, A.W. (Ed.). The ecology and management of grazing systems. Guildford: CAB International, 1996. cap.1, p.3-36.

MACHADO, A.O; CECATO, U.; MIRA, R.T.; PEREIRA, L.A.F.; MARTINS, E.N; DAMASCENO, J.C.; SANTOS, G.T. Avaliação de genótipos de Panicum maximum (Jacq) em duas alturas de corte. In: REUNIÃO ANUAL DA SOCIEDADE BRASILEIRA DE ZOOTECNIA, 34., Juiz de Fora, 1997. Anais. Juiz de Fora, SBZ, 1997. p.219-221.

MARSHALL, C. Physiological aspects of pasture growth. In: SNAYDON, R.W. Managed grasslands analytical studies. New York: Elsevier, 1987.

MELLO, A.C.L. Respostas morfofisiológicas do capim-Tanzânia (Panicum maximum Jacq cv. Tanzânia) irrigado à intensidade de desfolha sob lotação rotacionada. Piracicaba, 2002. 67p. Dissertação (Mestrado) - Escola Superior de Agricultura “Luiz de Queiroz”, Universidade de São Paulo.

MITAMURA, T. The effect of cutting on the dry matter production of orchardgrass sward (Dactylis glomerata L.). Bulletin of Institute for Agricultural Research Tohoku University, v. 24, p. 55-93, 1972.

PAIVA, F.A.; HERLING, V.R.; LUCHESI, M.M.; PADUA, M.B.; LUZ, P.H.C.; LIMA, C.G. Efeitos de ofertas de forragem e períodos de descanso na produção de matéria seca do capim Mombaça (P. maximum Jacq.). In. REUNIÃO ANUAL DA SOCIEDADE BRASILEIRA DE ZOOTECNIA, 38,. Piracicaba, 2001. Anais. Piracicaba: SBZ, 2001. p. 276-277. 
PARSONS, A.J; JOHNSON, I.R.; HARVEY, A. Use of a model to optimize the interaction between frequency and severity of intermittent defoliation to provide a fundamental comparison of the continuous and intermittent defoliation of grass. Grass and Forage Science, v.43, p. 49-59, 1988.

PINTO, J.C.; GOMIDE, J.A.; MESTRI, M. Produção de matéria seca e relação folha:caule de gramíneas forrageiras tropicais, cultivadas em vasos, com duas doses de Nitrogênio. Revista da Sociedade Brasileira de Zootecnia, v.23, n.3, p. 313326, 1994.

PINTO, L.F.M.; DA SILVA, S.C.; SBRISSIA, A.F.; CARVALHO, C.A.B.; CARNEVALli, R.A.; FAGUNDES, J.L. \& PEDREIRA, C.G.S.. Dinâmica do acúmulo de matéria seca em pastagens de Tifton 85 sob pastejo. Scientia Agricola, v. 58, n. 3, p. 439-447, 2001.

QUADROS, P.S.; RODRIGUES, L.R.A.; FAVORETTO, V.; MALHEROS, E.B.; RAMOS, A.K.B. Perdas de forragem em pastagens dos cultivares tanzânia e mombaça de $P$. maximum Jacq. adubadas com 4 doses de N,P e K. In. REUNIÃO ANUAL DA SOCIEDADE BRASILEIRA DE ZOOTECNIA, 38,. Piracicaba, 2001. Anais. Piracicaba: SBZ, 2001.p. 294-296.

REGO, F.; CECATO, U.; CANTO, M.V.; NIETO, L.M.; GOMES, J.A. CONEGLIAN, S. Estudo de características morfológicas e índice de área foliar do capim Tanzânia (P. maximum Jacq cv tanzânia 1) manejado em diferentes alturas, sob pastejo. In. REUNIÃO ANUAL DA SOCIEDADE BRASILEIRA DE ZOOTECNIA, 38, Piracicaba, 2001. Anais. Piracicaba: SBZ, 2001.p. 118-119. 
RHODES, I. Relationship between canopy structure productivity in herbage grasses and its implications for plant breeding. Herbage Abstracts. v. 43, p.129- 133, 1973.

SANTOS, P.M. Estudo de características de Panicum maximum(Jacq.) cvs. Tanzânia e Mombaça para estabelecer seu manejo. Piracicaba, 1997. 62p. Dissertação (Mestrado)-Escola Superior de Agricultura "Luiz de Queiroz", Universidade de São Paulo.

SANTOS, P.M.; CORSI, M.; BALSALOBRE, M.A.A. Efeito da frequiência de pastejo e da época do ano sobre a produção e a qualidade em Panicum maximum cvs. Tanzânia e Mombaça. Revista Brasileira de Zootecnia, v.28, n.2, p. 244-249, 1999.

SAS INSTITUTE. Language guide: version 6.03. Cary, 1989. 530 p.

SAVIDAN, Y.H.; JANK, L.; COSTA, J.C.G. Registro de 25 acessos selecionados de Panicum maximum. Campo Grande: EMBRAPA, CNPGC, 1990. 68 p. (EMBRAPA. CNPGC, Documentos, 44).

TAITON, N.M. Effects of different grazing rotations on pasture production. Journal of the British Grassland Society, v. 29, p.191-202, 1974.

TEIXEIRA, E.I. Avaliação de características morfológicas e nutricionais do capimTobiatã (Panicum maximum cv. Tobiatã) sob sistema de pastejo rotacionado. Piracicaba, 1998. 87p. Dissertação (Mestrado) - Escola Superior de Agricultura "Luiz de Queiroz", Universidade de São Paulo.

TOSI, P. Estabelecimento de parâmetros agronômicos para o manejo e eficiência de utilização de Panicum maximum Jacq. cv Tanzânia 1 sob pastejo rotacionado. Piracicaba, 1999.103 p. Dissertação (Mestrado)-Escola Superior de Agricultura "Luiz de Queiroz", Universidade de São Paulo. 
UEBELE, M.C. Padrões demográficos de perfilhamento e produção de forragem em pastos de capim Mombaça submetidos a regimes de lotação intermitente. Piracicaba, 2002. 83p. Dissertação (Mestrado)-Escola Superior de Agricultura "Luiz de Queiroz", Universidade de São Paulo.

WELLES, J.M.; NORMAN, J.M. Instrument for indirect measurement of canopy architecture. Agronomy Journal, v.83, p.818-825. 1991.

WILSON, D.B.; McGUIRE, W.S. Effects of clipping and nitrogen on competition between three pasture species. Canadian Journal of Plant Science, v. 41, p. 631642, 1961. 